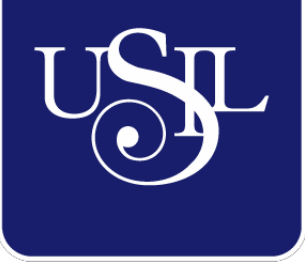

UNIVERSIDAD

SAN IGNACIO

DE LOYOLA

ESCUELA DE POSTGRADO

Maestría en Ciencias Empresariales

\title{
PLAN ESTRATÉGICO DE INCAS JEWELRY S.A.C. PERIODO 2019 - 2022
}

Trabajo de Investigación para optar el grado de Maestro en Ciencias Empresariales

\section{OLYENKA ELIZABETH GUTIÉRREZ CHONG CESAR ENRIQUE VICTOR LLANOS TARAZONA}

Asesor:

Niria Goñi Avila

Lima - Perú

2018 
A Dios.

Por darnos salud y su gran fortaleza para lograr nuestros objetivos, además por su inmensa bondad.

A nuestros padres.

Por inculcarnos a estudiar, gracias Raulito por tus sabios consejos, Elizabeth por cuidar de quienes tanto amamos, Susana por tu cariño y Víctor por bendecirnos siempre.

A nuestros hijos

Camila, la niña disciplinada, estudiosa y que todo que hace lo hace con pasión. A Mathías nuestro pequeño maestrito, quien persevera siempre. A ambos todo nuestro amor.

A nuestros profesores

Por su gran ayuda en desarrollar este Plan Estratégico, incluso cuando los buscamos fuera de sus horarios de clase y en especial a nuestra asesora la Dra. Niria Goñi Avila.

A la Universidad San Ignacio de Loyola

Por permitirnos ser parte de los profesionales que hacemos patria. 


\section{Resumen Ejecutivo}

El presente proyecto se desarrolla en base a una pequeña empresa que nació con el sueño de un grupo de hermanos y sus padres en constituir un negocio conjunto. Como la mayoría de empresas familiares esta inició sin un plan de negocios lo cual impidió que opere de manera ordenada y controlada resultando en una constante pérdida de dinero año tras año la cual recién fue cuantificada al ver los estados financieros que se construyeron para el desarrollo de este proyecto.

La empresa se dedica a la producción y comercialización de joyas de plata, artesanías, telares y piedras naturales. Actualmente cuenta con un local alquilado en una Galería de Miraflores y un fan page de Facebook. La mayoría de roles de la empresa están ocupados por el padre y los hijos de esta familia. Toda la inversión inicial y de los primeros años fue hecha por los mismos socios sin recurrir a financiamientos externos.

El objetivo general del trabajo fue desarrollar un Plan Estratégico de una pequeña empresa familiar con el objetivo de generar rentabilidad a futuro. Se planteó algunos objetivos específicos como analizar la situación actual de la empresa, comparar su posicionamiento con la competencia, trazar las estrategias y sus responsables, así como evaluar la viabilidad financiera del Plan Estratégico.

Se encontró una empresa que no tenía mayor registro de las actividades comerciales y operativas. No contaban con un sistema centralizado ni apoyo informático para la gestión del negocio. Las ventas a clientes y compras a proveedores eran anotadas casi aleatoriamente en un cuaderno. No tenían tampoco un inventario preciso que les permita conocer la rotación de los productos ni tener un plan de compra de insumos planificado.

Se planea elaborar un plan estratégico que busque reorientar el rumbo de la empresa volviéndola rentable y con ganancias considerables para un negocio que demanda mucho esfuerzo en su operación. Las estrategias seleccionadas abarcan una penetración de mercado ampliando los canales de venta y utilizando el comercio electrónico para aumentar la cantidad de clientes y los ingresos de la empresa.

La planificación demanda una inversión de S/. 186,975.00 que se inyectará de manera progresiva año a año desde el 2019 hasta el 2022 al igual que la ejecución de las estrategias seleccionadas. Se considera que este Plan Estratégico será exitoso ya que la empresa de por sí tiene un margen de venta por producto bastante bueno y con un solo canal de atención lo que 
nos da indicios de mucho potencial para crecer en ingresos y darle vuelta a la historia del negocio.

Finalmente, con la aplicación de las estrategias seleccionadas se logró dar un giro al rumbo comercial del negocio permitiendo incrementar los volúmenes de venta trayendo como consecuencia generar rentabilidad a niveles respetables para una empresa de este tamaño. Con esto también se demuestra que incluso una muy pequeña empresa puede ordenarse financiera y operacionalmente con un buen Plan Estratégico. 


\section{Tabla de Contenido}

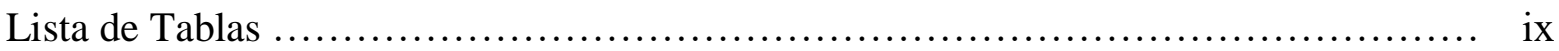

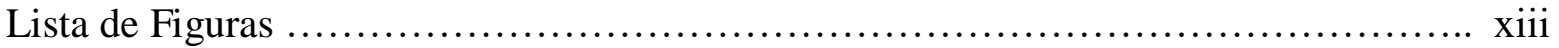

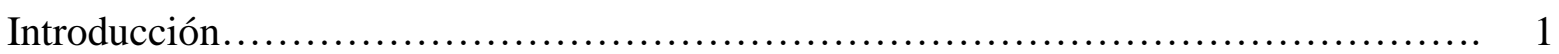

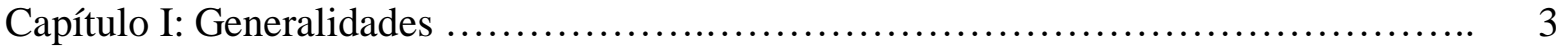

1.1. Antecedentes $\quad$............................................................... 3

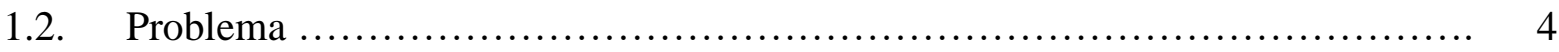

1.3. Justificación del Proyecto ........................................... 5

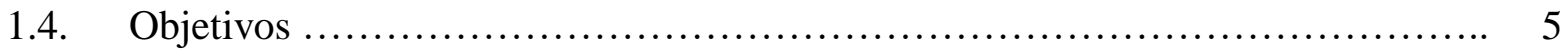

1.5. Alcances y Limitaciones de la Investigación .................................. 5

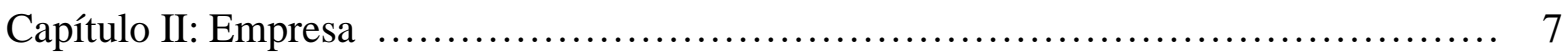

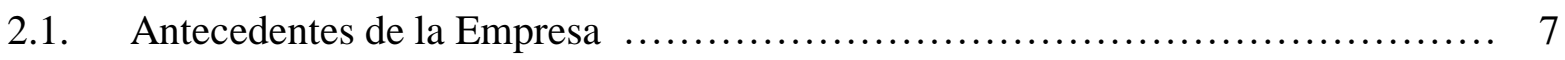

2.2. Descripción del Negocio $\quad$.......................................... 9

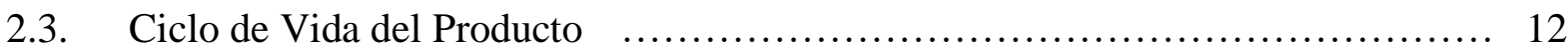

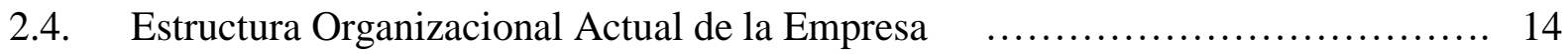

2.5. Situación de Mercado y Financiera Actual de la Industria .................... 17

Capítulo III: Formulación de Visión, Misión y Valores de la Empresa $\quad$................ 18

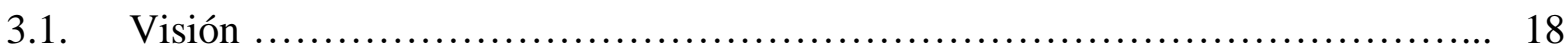

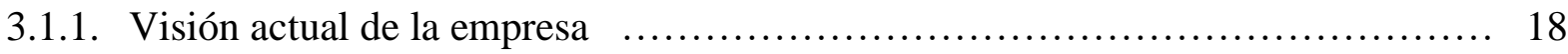

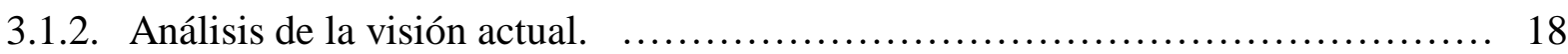

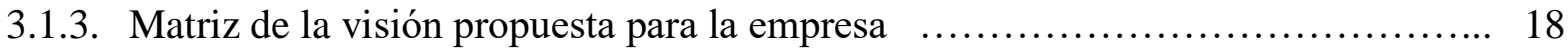

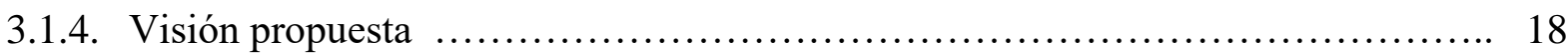

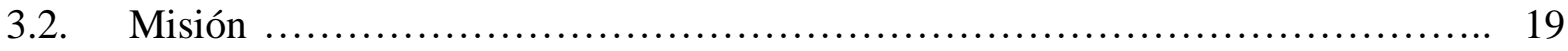

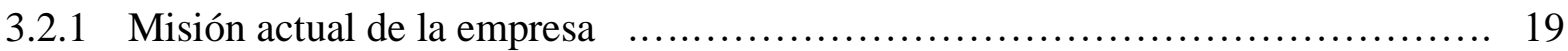

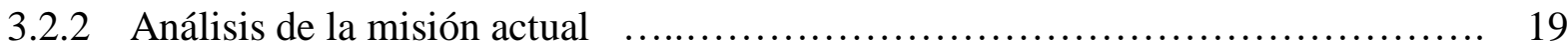

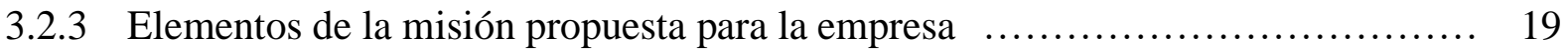

3.2.4. Misión propuesta. $\quad$................................................ 19

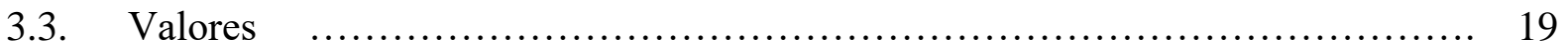

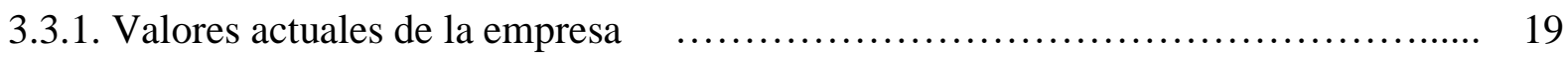

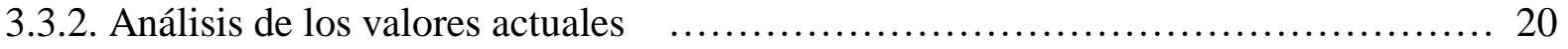




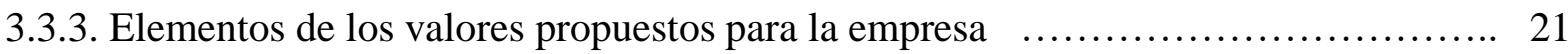

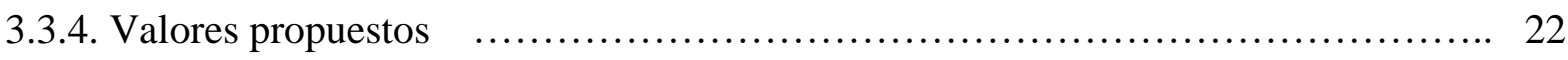

3.4. Alineamiento Estratégico de la Visión, Misión y Valores de la empresa ........... 22

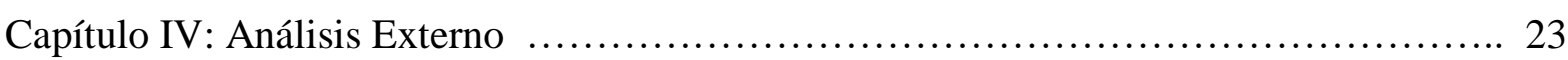

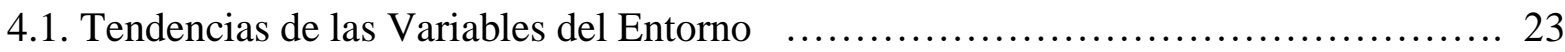

4.1.1. Análisis político-gubernamental. ....................................... 23

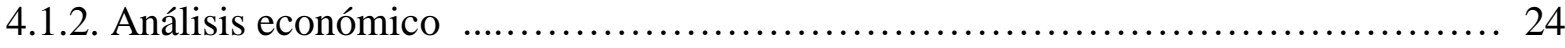

4.1.3. Análisis legal. ...................................................... 26

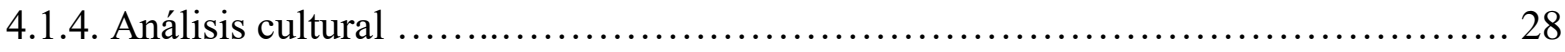

4.1.5. Análisis tecnológico. ................................................ 29

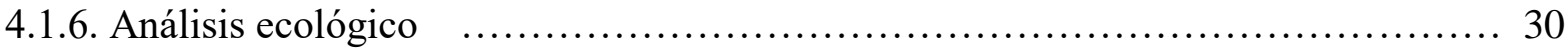

4.2. Impacto en Clientes / Proveedores de cada una de las Variables del Entorno .......... 31

4.3. Efecto en la Empresa de cada una de las Variables del Entorno $\quad . . \ldots \ldots \ldots \ldots \ldots \ldots . . . . . . .32$

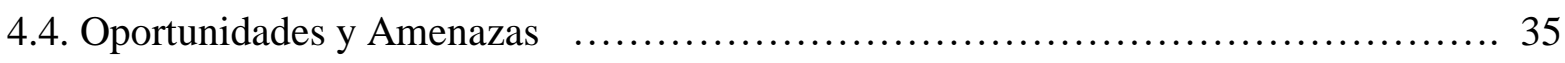

4.5. Matriz de Evaluación de los Factores Externos EFE $\quad$............................ 35

Capítulo V: Análisis de la Industria ........................................... 37

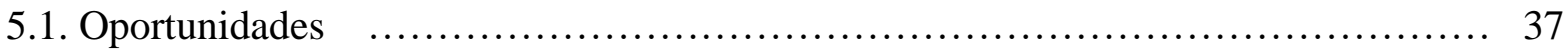

5.2. Descripción las Cinco Fuerzas Competitivas de la Industria $\quad \ldots \ldots \ldots \ldots \ldots \ldots \ldots \ldots . \ldots . \ldots$

5.2.1. Sustitutos - Desarrollo potencial de productos sustitutos $\quad \ldots \ldots \ldots \ldots \ldots \ldots \ldots \ldots \ldots \ldots$

5.2.3. Clientes - Poder de negociación de los consumidores $\quad \ldots \ldots \ldots \ldots \ldots \ldots \ldots \ldots \ldots . \ldots 1$

5.2.4. Proveedores - Poder de negociación de los proveedores $\quad \ldots \ldots \ldots \ldots \ldots \ldots \ldots \ldots \ldots . .42$

5.2.5. Competencia en el mismo sector - Rivalidad entre empresas competidoras ........ 43

5.3. Matriz de Atractividad de cada una de las Cinco Fuerzas $\quad \ldots \ldots \ldots \ldots \ldots \ldots \ldots \ldots \ldots . . \ldots 4$

5.4. Análisis del Grado de Atractividad de la Industria .............................. 48

5.4.1 Sustitutos - Desarrollo potencial de productos sustitutos $\ldots \ldots \ldots \ldots \ldots \ldots \ldots \ldots \ldots \ldots . \ldots 49$

5.4.2 Potenciales - Entrada potencial de nuevos competidores $\ldots \ldots \ldots \ldots \ldots \ldots \ldots \ldots \ldots \ldots$

5.4.3 Clientes - Poder de negociación de los consumidores $\ldots \ldots \ldots \ldots \ldots \ldots \ldots \ldots \ldots \ldots \ldots 1$

5.4.4. Poder de Negociación de los proveedores ................................. 52

5.5.5. Competencia en el mismo sector - Rivalidad entre empresas competidoras ......... 54

5.5. Matriz de Perfil Competitivo MPC …...................................... 55 
Capítulo VI: Análisis Interno ................................................. 57

6.1. Descripción de las Actividades de la Cadena de Valor de la Empresa .............. 57

6.2. Indicadores de cada una de las Actividades de la Cadena de Valor .................. 61

6.3. Benchmarking y Comparación con los Líderes de la Industria de Cada Una de las

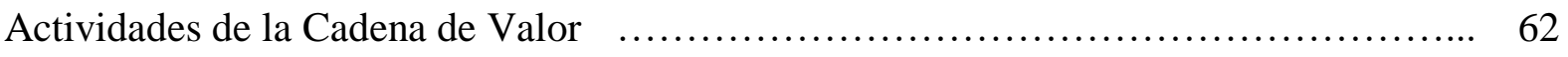

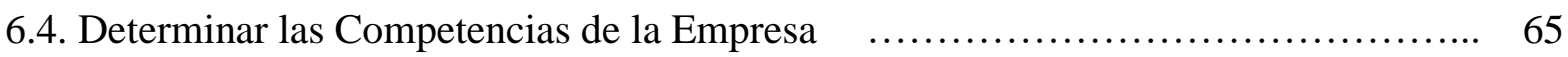

6.6. Matriz de Evaluación de los Factores Internos EFI .......................... 67

Capítulo VII: Formulación de los Objetivos y Diseño de las Estrategias $\quad$............... 69

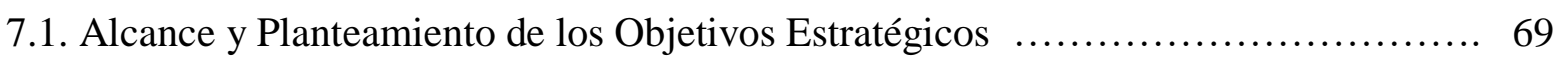

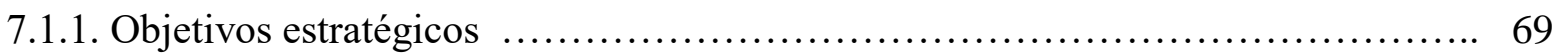

7.1.2. Análisis de los objetivos estratégicos .................................. 69

7.2. Diseño y Formulación de Estrategias $\quad$........................................ 70

7.2.1. Modelo Océano Azul ............................................... 71

7.2.1.1. Lienzo de la Estrategia Actual de la Empresa $\quad$............................... 71

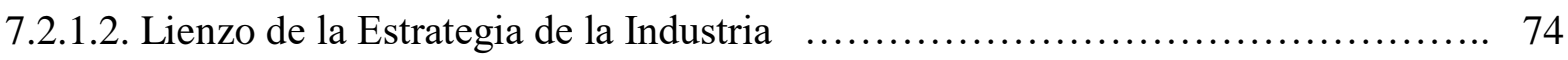

7.2.1.3. Matriz Eliminar, Reducir, Incrementar, Crear ........................... 77

7.2.1.4. Lienzo de la Nueva Estrategia Considerada .............................. 79

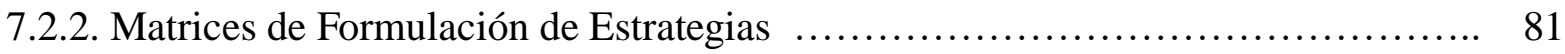

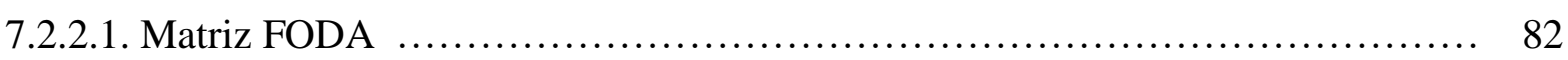

7.2.2.2. Matriz PEYEA ........................................................ 82

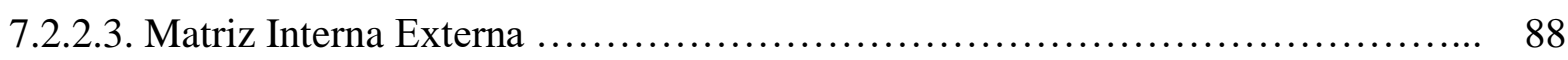

7.2.2.4. Matriz Boston Consulting Group ...................................... 89

7.2.2.5. Matriz de la Gran Estrategia .......................................... 92

7.3. Resumen de las Estrategias Formuladas ..................................... 95

Capítulo VIII: Selección de la Estrategia ........................................ 98

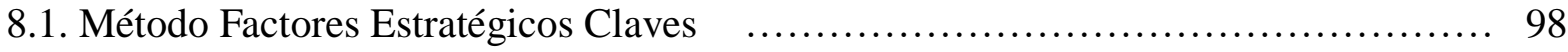

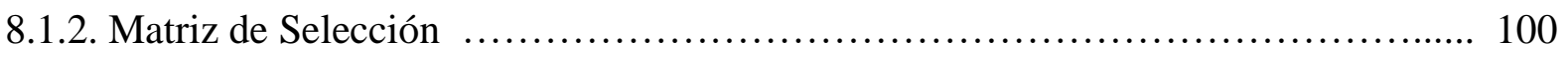

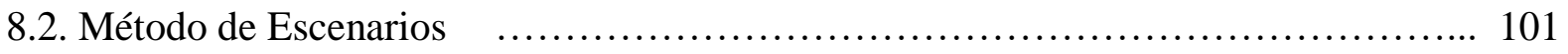

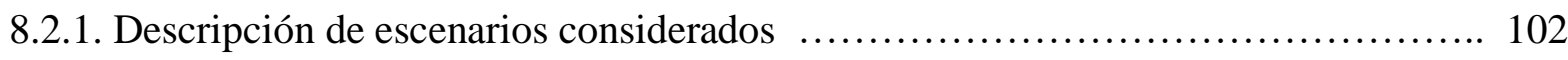

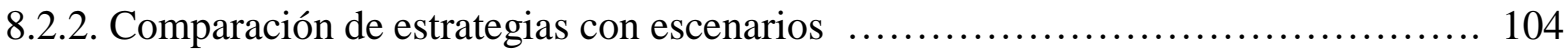

8.3. Matriz de Planeación Estratégica Cuantitativa MPEC ............................ 105 
8.4. Descripción de Estrategia Seleccionada ....................................... 106

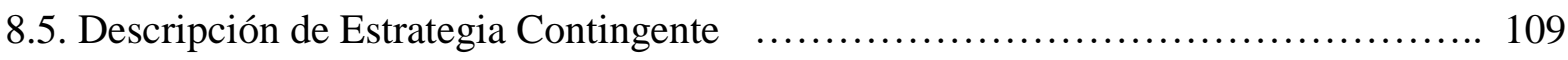

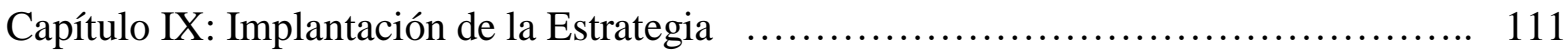

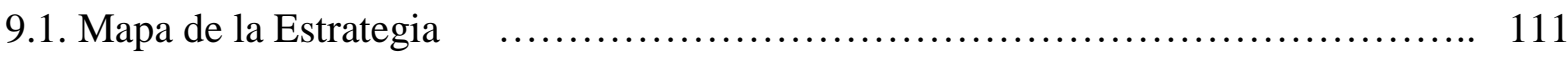

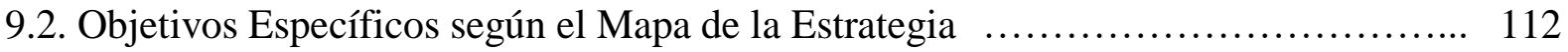

9.3. Indicadores para cada uno de los Objetivos Específicos ....................... 114

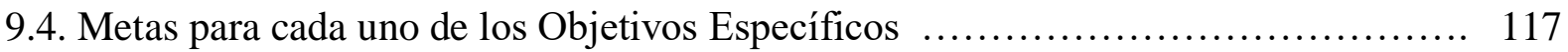

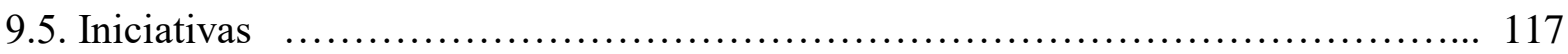

9.6. Responsable de cada una de las Iniciativas $\quad$................................ 120

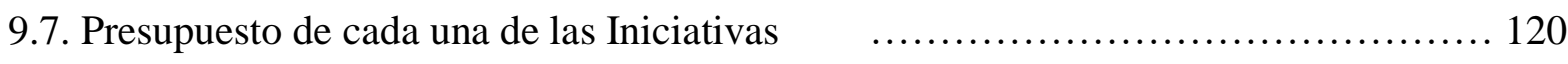

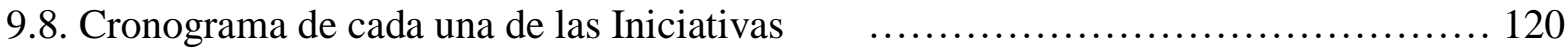

Capítulo X: Evaluación .................................................... 142

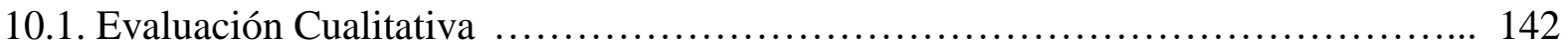

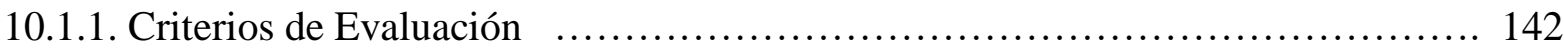

10.1.2. Comparación de la Estrategia con los Criterios $\quad$............................. 142

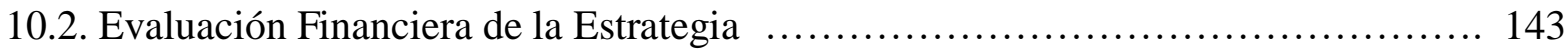

10.2.1. Estado de Resultados (Situación actual y con la nueva estrategia) $\quad$............... 143

10.2.2. Balance General (Situación actual y con la nueva estrategia) ................... 143

10.2.3. Flujo de Efectivo (Situación actual y con la nueva estrategia) $\ldots \ldots \ldots \ldots \ldots \ldots \ldots . \ldots 147$

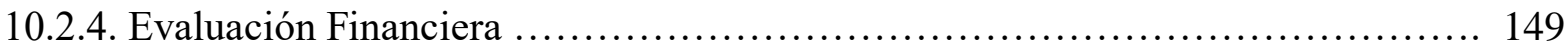

Capítulo XI: Conclusiones y Recomendaciones .................................. 150

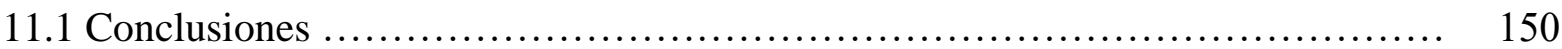

11.2. Recomendaciones ................................................... 151

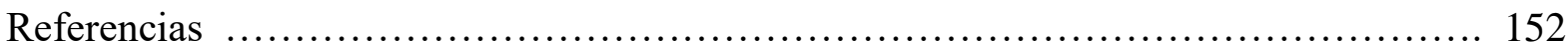

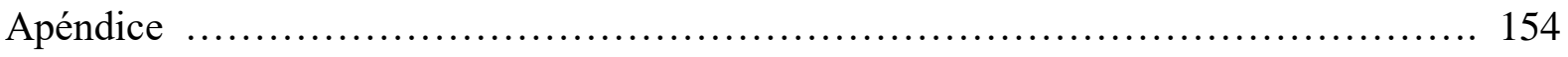




\section{Lista de Tablas}

Tabla 1. Resumen de las Características, Objetivos y Estrategias del Ciclo de Vida ...... 13

Tabla 2. Etapa de Crecimiento ................................................. 14

Tabla 3. Matriz de la Visión Propuesta para la Empresa ............................. 19

Tabla 4. Elementos de la Misión Propuesta para la Empresa ......................... 20

Tabla 5. Alineamiento Estratégico de la Visión, Misión y Valores de la empresa ......... 22

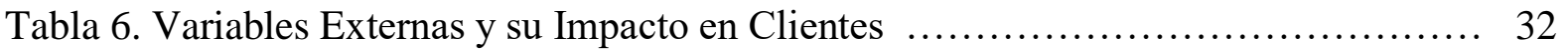

Tabla 7. Variables Externas y su Impacto en Proveedores ......................... 33

Tabla 8. Variables Externas y su Efecto en la Empresa .............................. 34

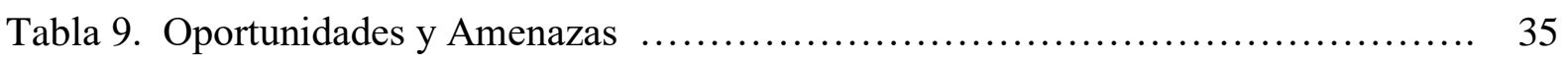

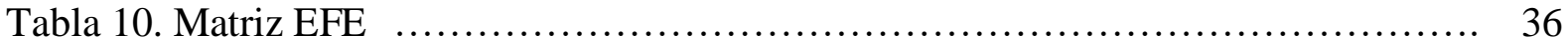

Tabla 11. Matriz de Atractividad de la Fuerza "Desarrollo Potencial de

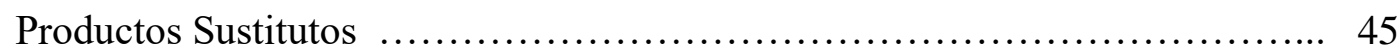

Tabla 12. Matriz de Atractividad de la Fuerza "Entrada Potencial de

Nuevos Competidores" ........................................... 46

Tabla 13. Matriz de Atractividad de la Fuerza "Poder de Negociación

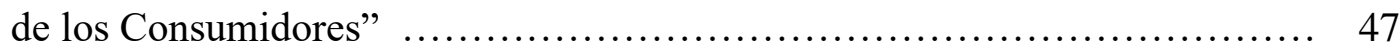

Tabla 14. Matriz de Atractividad de la Fuerza "Poder de Negociación

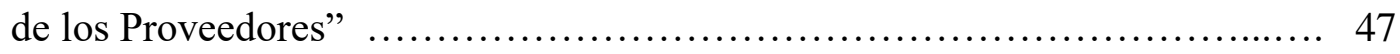

Tabla 15. Matriz de Atractividad de la Fuerza "Rivalidad entre

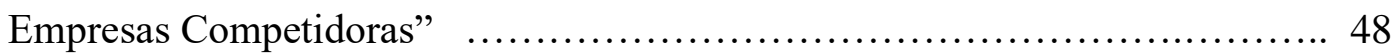

Tabla 16. Matriz de Atractividad de las cinco Fuerzas .............................. 55

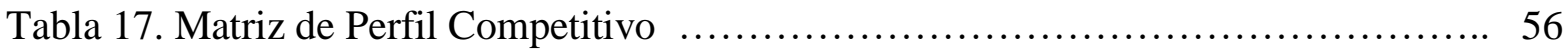

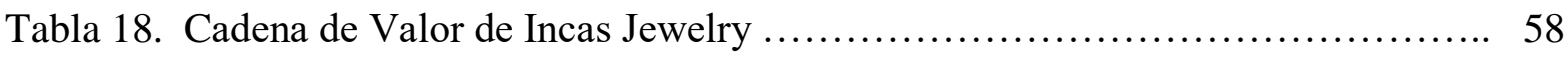

Tabla 19. Indicadores de las Actividades Primarias y de Apoyo as Jewelry ............ 62

Tabla 20. Benchmarking y Comparación con los Líderes de la Industria

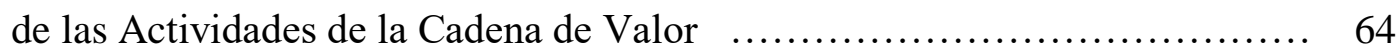

Tabla 21. Competencias de la Empresa Incas Jewelry SAC ......................... 65

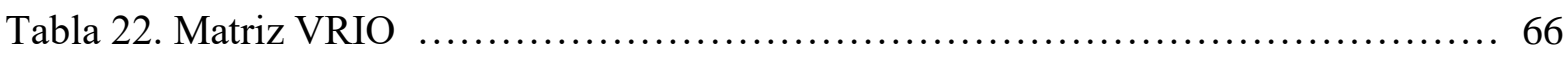


Tabla 23. Matriz VRIO Incas Jewelry ......................................... 66

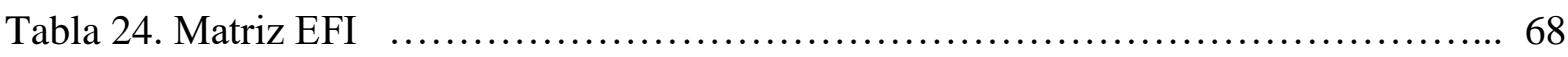

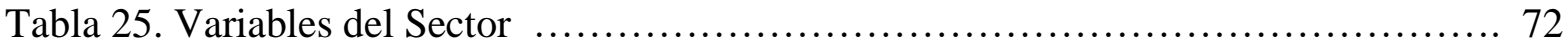

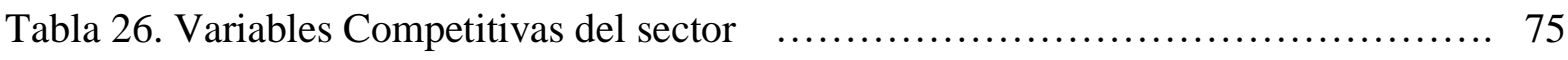

Tabla 27. Matriz Eliminar, Reducir, Incrementar y Crear $\ldots \ldots \ldots \ldots \ldots \ldots \ldots \ldots \ldots \ldots \ldots \ldots \ldots$

Tabla 28. Variables Identificadas |para el Cumplimiento del Objetivo Estratégico ....... 80

Tabla 29. Variables de la Matriz Eliminar, Reducir, Incrementar y

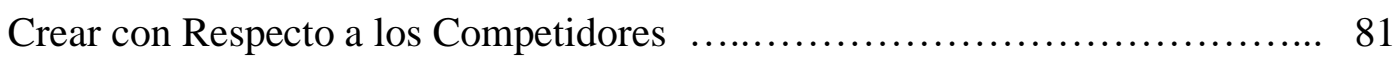

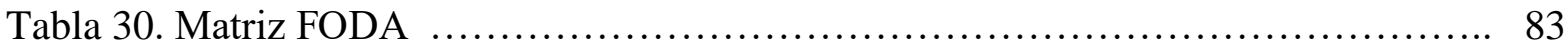

Tabla 31. Factores que Constituyen las Variables de los Ejes de la Matriz PEYEA ....... 85

Tabla 32. Matriz Posición Estratégica y Evaluación de la Acción - MPEYEA ........... 87

Tabla 33. Participación de Mercado y Tasa de Crecimiento .......................... 91

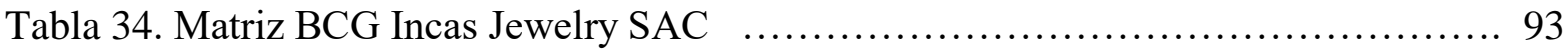

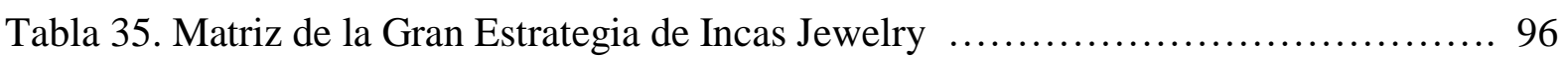

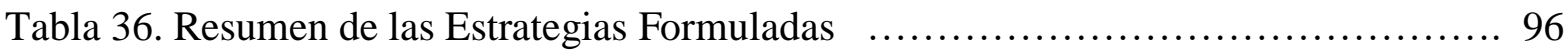

Tabla 37. Estrategias de las Matrices Sugeridas a Incas Jewelry SAC . ................ 97

Tabla 38. Matriz de Decisión Estratégica (MDE) ................................. 101

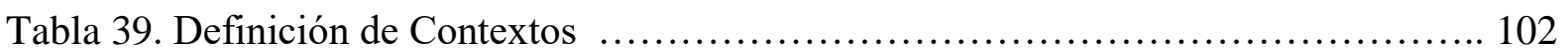

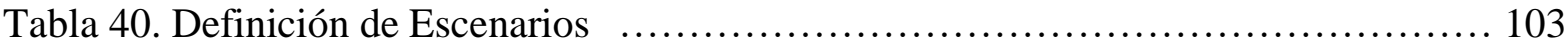

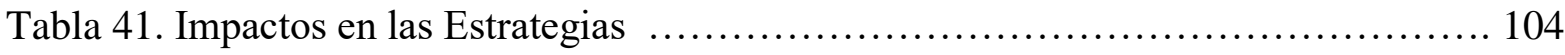

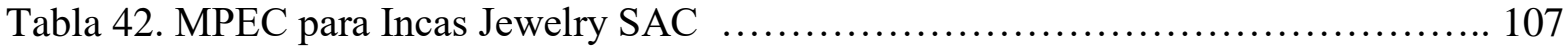

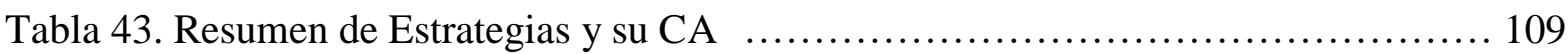

Tabla 44. Descripción de la Estrategia propuesta para Incas Jewelry SAC ................ 109

Tabla 45. Descripción de Estrategias Contingentes Propuestas para Incas Jewelry SAC ... 110

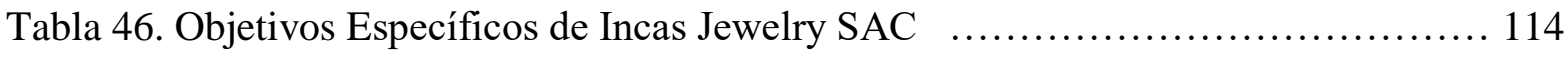

Tabla 47. Indicadores P. Financiera, Clientes, Procesos Internos y Aprendizaje ....... 116

Tabla 48. Metas de Perspectiva Financiera, Clientes, Procesos Internos y Aprendizaje ... 118

Tabla 49. Iniciativas Perspectiva Financiera, Clientes, Procesos Internos y Aprendizaje .. 119

Tabla 50. Responsables de Cada Iniciativa de Perspectiva Financiera y Clientes ........ 121

Tabla 51. Responsables de Cada Iniciativa de Perspectiva Interna y Aprendizaje ......... 122 
Tabla 52. Presupuesto de cada Iniciativa de la Perspectiva Financiera y Cliente $\ldots . . . . .123$

Tabla 53. Presupuesto de Cada Iniciativa de la Perspectiva Interna y Aprendizaje ........ 124

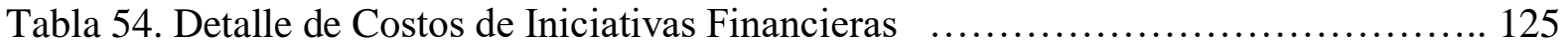

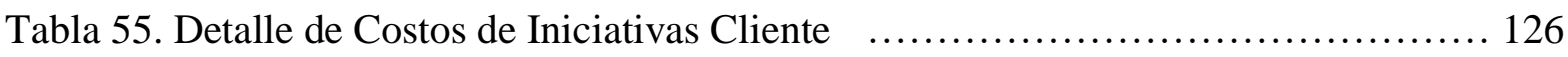

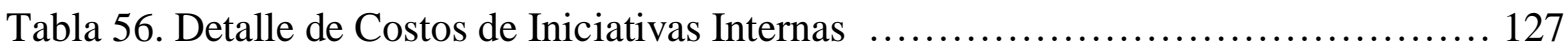

Tabla 57: Detalle de Costos de Iniciativas Aprendizaje .......................... 127

Tabla 58. Cronograma 2019 de Cada Iniciativa y sus Responsables

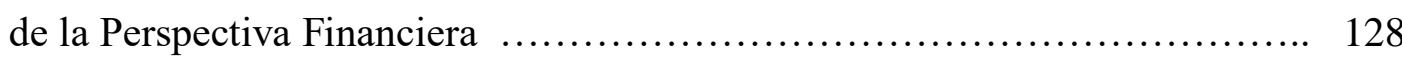

Tabla 59. Cronograma 2020 de Cada Iniciativa y sus Responsables

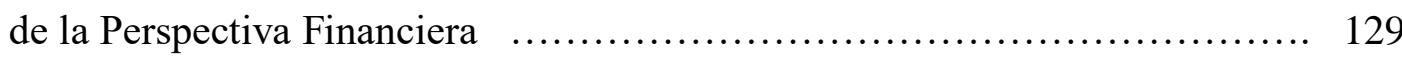

Tabla 60. Cronograma 2021 de Cada Iniciativa y sus Responsables de la Perspectiva Financiera ...................................... 130

Tabla 61. Cronograma 2022 de cada Iniciativa y sus Responsables de la Perspectiva Financiera

Tabla 62. Cronograma 2019 de Cada Iniciativa y sus Responsables de la Perspectiva Cliente

Tabla 63. Cronograma 2020 de Cada Iniciativa y sus Responsables de la Perspectiva Cliente

Tabla 64. Cronograma 2021 de Cada Iniciativa y sus Responsables de la Perspectiva Cliente

Tabla 65. Cronograma 2022 de Cada Iniciativa y sus Responsables de la Perspectiva Cliente

Tabla 66. Cronograma 2019 de Cada Iniciativa y sus Responsables de la Perspectiva Interna

Tabla 67. Cronograma 2020 de Cada Iniciativa y sus Responsables de la Perspectiva Interna

Tabla 68. Cronograma 2021 de Cada Iniciativa y sus Responsables de la Perspectiva Interna

Tabla 69. Cronograma 2022 de Cada Iniciativa y sus Responsables de la Perspectiva Interna 
Tabla 70. Cronograma 2019 de Cada Iniciativa y sus Responsables de la Perspectiva Aprendizaje 140

Tabla 71. Cronograma 2020 de Cada Iniciativa y sus Responsables de la Perspectiva Aprendizaje 140

Tabla 72. Cronograma 2021 de Cada Iniciativa y sus Responsables de la Perspectiva Aprendizaje 141

Tabla 73. Matriz de Rumelt 143

Tabla 74. Estado de Resultados - Situación Actual sin estrategia 144

Tabla 75. Estado de Resultados - Con la nueva estrategia 144

Tabla 76. Balance General - Situación Actual 145

Tabla 77. Balance General - Con Estrategia 146

Tabla 78. Flujo de Efectivo - Situación Actual 147

Tabla 79. Flujo de Efectivo - Con Estrategia 147

Tabla 80. Flujo de Efectivo Mensual - Con Estrategia 148

Tabla 81. Evaluación Financiera - VAN 149 


\section{Lista de Figuras}

Figura 1: Trabajo de Calado .................................................... 10

Figura 2: Trabajo de Puntillado en Plata ........................................ 10

Figura 3: Trabajo de Estampado en Plata ...................................... 11

Figura 4: Trabajo de Tejido en Plata ........................................ 11

Figura 5: Mesa de Joyero .............................................. 11

Figura 6: Organigrama de Incas Jewelry ..................................... 15

Figura 7: Modelo Analítico para la Formulación de Estrategias ....................... 70

Figura 8: Lienzo de la Estrategia de Incas Jewelry ................................ 73

Figura 9: Lienzo de la Estrategia de la Industria .............................. 77

Figura 10: Esquema de las Cuatro Acciones ...................................... 78

Figura 11: Cuadro Estratégico de los Competidores Principales ........................ 79

Figura 12: Lienzo de la nueva estrategia considerada ........................... 81

Figura 13: Matriz PEYEA ................................................ 84

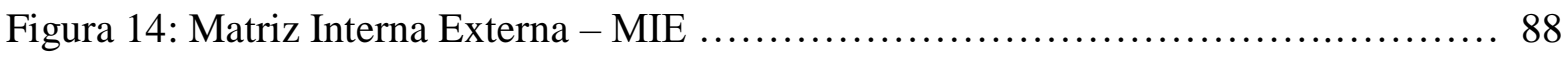

Figura 15: Matriz Interna Externa de la empresa Incas Jewelry .......................... 89

Figura 16: Matriz BCG.................................................. 90

Figura 17: Matriz de la Gran Estrategia $\quad$................................... 94

Figura 18: El Reloj Estratégico de Bowman ...................................... 98

Figura 19: Mapa Estratégico................................................ 112

Figura 20: Mapa Estratégico de Incas Jewelry ................................. 113 


\section{Lista de Apéndices}

Apéndice A1. Entrevista en Profundidad al Gerente General ..................... 154

Apéndice A2. Entrevista en Profundidad a Gerente de Tienda - Parte 1 ............. 157

Apéndice A3. Entrevista en Profundidad a Gerente de Tienda - Parte 2 ............. 158

Apéndice A4. Entrevista en Profundidad al Gerente de Operaciones ................ 160

Apéndice A5. Entrevista en Profundidad al Experto en la Industria - Mincetur ........ 162

Apéndice A6. Entrevista en Profundidad a la Competencia - Gte General Joyas M\&F . 164

Apéndice A7. Entrevista en Profundidad a la Competencia - Adm.de Spondylus ....... 166

Apéndice B1. Cuestionario al Gremio de Artesanos Inscritos en Promperú ............. 168

Apéndice B2. Cuestionario a Clientes de Incas Jewelry SAC ...................... 172 


\section{Introducción}

La presente tesis es un proyecto que busca consolidar y aplicar los conocimientos adquiridos durante los años de estudio de la Maestría. La sustentación final de esta tesis tiene como finalidad obtener el grado universitario de Magister. La tesis comprende desarrollar un plan estratégico aplicado a una pequeña empresa familiar llamada Incas Jewelry S.A.C. Se entrevistó a personal interno y a expertos de la industria que permitieron el desarrollo de cada una de las unidades del trabajo.

El objetivo general del trabajo fue desarrollar un Plan Estratégico de una pequeña empresa familiar dedicada a la producción y comercialización de joyas de plata, con el fin de mejorar la rentabilidad a futuro. Se planteó algunos objetivos específicos como analizar la situación actual de la empresa, comparando su posicionamiento con la competencia, trazando las estrategias y sus responsables, así como evaluar la viabilidad financiera del Plan Estratégico.

En el capítulo I se presenta las generalidades del proyecto. Se inicia con los antecedentes centrados en cómo se encuentra la industria joyera en el Perú y nombrando a las pequeñas microempresas, se determinó el problema y oportunidad, justificación del proyecto especificando la razón del proyecto, objetivos generales y específicos. También los alcances y limitaciones de la investigación;

En el capítulo II se aborda a los datos de la empresa, antecedentes, descripción del negocio, ciclo de vida del producto, actual estructura organizacional y la situación de mercado y financiera de la industria joyera. Es importante esto para entender el contexto del mercado donde la empresa se encuentra involucrada y separándola de la actividad minera a pesar de que se trabaja con la plata como principal metal en la elaboración de los productos.

En el capítulo III se presenta la actual visión y misión de la empresa y se proponen nuevos. También esta los valores de la misma por lo que se proponen nuevos de acuerdo a los criterios argumentados en el trabajo con lo cual se realiza un alineamiento estratégico de la visión, misión y valores de la empresa. Con esto mostramos cual era el rumbo que tenía la empresa como institución y hacia a donde apunta ahora.

En el capítulo IV se presenta todo el análisis externo, tendencia de las variables político-gubernamental, económica, legal, cultural, tecnológica, ecológica. Se describió el impacto en clientes, proveedores y su efecto en cada una de variables del entorno. Esto permite conocer todo lo que afecta a la empresa y con los datos obtenidos se elabora la matriz de evaluación de los factores externos EFE. 
En el capítulo V se presenta el análisis de la industria, descripción del mercado e industria, se describe las cinco fuerzas competitivas de la industria como: Desarrollo potencial de productos sustitutos, entrada potencial de nuevos competidores, poder de negociación de los consumidores y proveedores y la rivalidad entre empresas competidoras, con estos datos se elaboró la matriz de atractividad y la matriz del perfil competitivo MPC.

En el capítulo VI se presenta el análisis interno en el cual se describió las actividades de la cadena de valor de la empresa en sus diversas unidades de negocio, se formuló los indicadores de cada una de las actividades de la cadena de valor. Se realizó un benchmarking comparándolos con los líderes de la industria y con los obtenidos se elaboró la matriz de evaluación de los factores internos EFI.

En el capítulo VII se formularon los objetivos y diseñó las estrategias mediante el modelo del océano azul para lo que se elaboró los lienzos de la estrategia actual de la empresa y de la industria joyera, la matriz eliminar, reducir, incrementar y crear. Para la formular las estrategias se elaboró la matriz FODA, PEYEA, MIE, BCG y Gran Estrategia. Y con los datos obtenidos se realizó el resumen de las estrategias formuladas.

En el capítulo VIII se abordó la selección de la estrategia utilizando el método de factores estratégicos claves, matriz de selección, método de escenarios para lo cual se describió los escenarios y se comparó con las estrategias en los escenarios menos y más probables de ocurrencia. También se realizó la matriz MPEC, obteniendo en este punto la estrategia que se selecciona para el trabajo y su contingencia.

En el capítulo IX se presenta la implantación de la estrategia mediante el mapa de la estrategia con sus respectivos objetivos específicos, indicadores, metas, iniciativas, responsables, presupuesto y cronograma de cada una de las iniciativas. Estos son los indicadores que luego nos permitirán controlar, evaluar y si fuese necesario reorientar esfuerzos.

En el capítulo $X$ se presenta la evaluación cualitativa financiera, proyección de estados financieros, estados de resultados, balance general, flujo de efectivo, proyección de flujos, evaluación financiera VAN que nos permite numéricamente ver el comportamiento histórico del negocio, la ejecución de estrategias y el cambio de rumbo de la empresa hacia el ansiado incremento de rentabilidad.

Finalmente se presenta las conclusiones, recomendaciones, referencias y apéndices para cerrar todo lo elaborado en este proyecto de análisis, selección y ejecución de estrategias utilizando todos los mecanismos, métodos e indicadores aprendidos durante los años de estudio de la Maestría. 


\section{Capítulo I: Generalidades}

En el presente capítulo se presentó los antecedentes del proyecto, se determinó el problema y oportunidad, justificación del proyecto, objetivos generales y específicos y los alcances y limitaciones de la investigación. Para su elaboración se consultó publicaciones de Asociación de Exportadores (Adex), Ministerio de Comercio Exterior y Turismo (Mincetur), Instituto Nacional de Estadística e Informática (INEI) y experiencia de los autores, la idea fue detallar el estado actual de la industria de la joyería en Lima y así poder dar los alcances generales y justificación del porque se eligió este proyecto.

\subsection{Antecedentes}

Perú es el país con las reservas de plata más grandes del mundo y su mercado local de joyería mueve unos US\$ 57 millones al año, mientras que el mercado internacional genera unos US\$ 8,800 millones anuales. Asimismo, se sabe que el Perú es el segundo productor mundial de plata (Mincetur, 2017). Adex señala que la actividad de la joyería genera cerca de 25,000 puestos de trabajo, directos e indirectos en el país. En uno de los congresos internacionales de Joyería y Orfebrería organizado por Adex, Mincetur y Comisión de Promoción del Perú para la Exportación y el Turismo (Promperú), señalaron que solo 3000 talleres artesanales de joyería están inscritos en el Registro Nacional de Artesanos Mincetur a los que se suman las empresas manufactureras, grandes y medianas". Mincetur (2017)

Los artesanos consiguen la plata piña ${ }^{1}$ por kilos para poder producir joyas de plata en sus diferentes variedades y aleaciones de 9.25 y 9.50. Es importante mencionar que la plata de ley o plata esterlina 925 tiene una aleación $92.5 \%$ plata pura y $7.5 \%$ de cobre. La principal distribuidora y comercializadora de plata en el Perú es la "Procesadora Sudamericana S.R.L. primera refinería del Perú, El gramo de plata al 26-01-18 cuesta 1.80 soles y el kilo 1800.26 soles.

Las principales micro empresas de joyerías que están posicionadas en el mercado y son parte de la competencia directa de la empresa son: Platelia, Artesanía Platería Jeny, Joyería Piero, Spondylus, Laia, Joyas M\&F, Diana, todas ubicadas en Miraflores, dedicadas al diseño, fabricación y comercialización de joyas de plata. Incas Jewelry S.A.C. inició sus operaciones a través de internet vendiendo joyas de plata 950 con diseños comerciales. Su

\footnotetext{
${ }^{1}$ Plata Piña: Masa esponjosa de plata cuyo nivel de pureza es muy blanda, se usa para hacer trabajos con hilos de plata en los que se requiere que el metal tenga mucha flexibilidad. (Española, Plata Piña, 2016)
} 
público no fue tan selecto porque no se realizó ningún tipo de estudio ni segmentación de mercado. Los clientes en su mayoría eran peruanos del sexo femenino. Luego de cinco años de llevar un negocio de manera informal se aventuró a alquilar una tienda en Miraflores, en la sección de Mercado Indio, donde el público pasó a ser en su mayoría turistas extranjeros o peruanos que residen en otros países. Con ello se tuvo que realizar ciertos cambios como cambiar el nombre de la tienda y para incrementar capital se tuvo que aceptar nuevos socios. Asimismo, se elaboró nuevos diseños étnicos para las joyas, los cuales son demandados por el público.

\subsection{Problema}

El mercado de ventas de joyas de plata ha crecido de manera exponencial apareciendo una gran cantidad de competidores lo que origina una pérdida de participación de mercado, disminución de las ventas y reducción de márgenes de ganancia. La empresa no maximiza el uso de la tecnología y los nuevos canales de comunicación con clientes para posicionarse, relacionarse y fidelizar a sus clientes, pero si se diferencia en calidad de productos y el servicio brindado. Partiendo de la premisa de mantenerse en el tiempo e incrementar rentabilidad como empresa, no se cuenta con estrategias que sean aplicadas de manera coordinada por todos los agentes de la organización.

La empresa actualmente no cuenta con un Plan Estratégico y mantiene un local comercial en Miraflores. Las ventas diarias no son registradas en ningún sistema, se documenta de manera manual en un cuaderno. Varios de los proveedores son artesanos informales en los que no siempre se puede confiar ni para pagos ni para entrega de piezas. No todos los procesos se encuentran documentados.

Se viene trabajando conjuntamente entre ADEX, el Instituto de la Calidad (Inacal) y el Indecopi para sacar adelante una certificación ${ }^{2}$ que garantice que el producto elaborado y comprado cuente con la cantidad de quilates y la pureza que se está ofreciendo. En vista de que la empresa no cuenta con un Plan Estratégico, esto será una gran oportunidad de negocio porque brindará garantía y seguridad al joyero de que la empresa ha seguido procedimientos rigurosos y podrá así competir en igual de condiciones con otros productores de joyas en el mundo respaldando el incremento de las ventas. Se propone un Plan Estratégico, con el objetivo de tener una idea clara de cuáles son los objetivos de la empresa, fijar dirección hacia el éxito, que apunte a los resultados que se pretende alcanzar y establecer un curso de acción para lograr alcanzarlos.

\footnotetext{
${ }^{2}$ Certificación basada en normas técnicas internacionales (Adex, 2017)
} 


\subsection{Justificación del Proyecto}

La elaboración de este proyecto tuvo como finalidad en principio plantear una serie de acciones que permitan darle un giro radical a la rentabilidad de este negocio cuyos niveles se encuentran muy por debajo de lo que cualquier empresa precisa para subsistir y generar ganancias. Asimismo, la aplicación con fines educativos de la metodología y conocimiento recibido en los cursos de la Maestría, que los autores de este proyecto siguieron, para el gran objetivo final que es la obtención del Grado de Magister.

\subsection{Objetivos}

Objetivo General del Proyecto:

Desarrollar el Plan Estratégico de una pequeña empresa familiar dedicada a la producción y comercialización de joyas de plata, con el fin de mejorar la rentabilidad a futuro.

Objetivos específicos del Proyecto. Se listan los objetivos del proyecto:

- Analizar la situación actual de la empresa

- Formular los objetivos de la empresa.

- Evaluar la visión y misión de la empresa.

- Hacer un análisis externo a nivel macro identificando las variables del entorno que impactan al negocio.

- Elaborar un análisis del mercado en el cual se encuentra la empresa.

- Determinar el posicionamiento de la empresa versus la competencia.

- Hacer un análisis interno identificando fortalezas y debilidades

- Trazar la ejecución de las estrategias y asignar sus responsables.

- Evaluar la viabilidad financiera del Plan Estratégico.

\subsection{Alcances y Limitaciones de la Investigación}

Alcances:

El alcance del presente trabajo abarcó el mercado objetivo compuesto por turistas extranjeros que suelen visitar y comprar las joyerías de Miraflores, Lima.

\section{Limitaciones:}

El sector de la Joyería tiene un gran impacto socioeconómico en nuestro país, pero no se cuenta con estadísticas claras que indiquen realmente como va su crecimiento. Esto se debe al alto número de empresas informales que manejan precios muy competitivos por sus bajos costos, que no cuentan con garantía, pero el público opta por comprarles dándole mayor peso al precio que a la calidad en su decisión. 
No contar con estadísticas de los compradores de plata que permita conocer los gustos y preferencias en cuanto a compra de joyas de plata es una limitación debido a que la mayoría de los compradores son de procedencia extranjera. Al no existir buenas costumbres comunes en la fabricación o producción de joyas es una limitación ya que no permite reconocer las mejores prácticas implementadas. 


\section{Capítulo II: Empresa}

En el presente capítulo se presenta los antecedentes de la empresa, descripción del negocio, ciclo de vida del producto, se procedió a colocar solo el ciclo actual de la empresa. La estructura organizacional actual de la empresa, la cual fue retroalimentada con entrevistas en profundidad a personal interno que podrán ser encontradas en los apéndices con sus respectivas guías y cuestionarios. Las transcripciones de las mismas están en un anexo aparte que podrá ser revisada por quien lo requiera. Finalmente se describirá la situación actual de mercado y financiera de la empresa.

\subsection{Antecedentes de la Empresa}

En el 2009 dos hermanas decidieron emprender un pequeño negocio de venta de joyas de plata. Las piezas eran compradas a diversos artesanos de Lima, no existía exclusividad en los diseños y el arte se vendía a los contactos como familia, amigos entre otros. En el año 2010 los clientes ya pedían joyas con sus propios diseños y con buenos acabados.

En el año 2013, tres de los hermanos se animaron a estudiar el oficio de diseño y producción de joyas, con lo cual cada uno logró especializarse en diferentes técnicas con la intención de poder satisfacer a los clientes, ofreciendo de esta manera, una pieza única trabajada con mucho profesionalismo. A mediados del 2014 se tomó la decisión de alquilar talleres con máquinas por horas según los pedidos solicitados. Para ello se juntaban los pedidos y se alquilaba una vez por semana para la producción de las joyas. En este lugar se conoció a varios artesanos con mucha experiencia a quienes se les contrataba para que trabajen los diseños más complicados o que necesitaban mayor precisión a fin de que la pieza cumpla las características solicitadas por el comprador.

En el año 2014, los hermanos saliendo de sus clases de joyería en Miraflores, vieron un local en alquiler y fue ahí que decidieron constituir una empresa de joyas. Con esa motivación llamaron a otros socios capitalistas con la intención de poder cubrir los gastos necesarios como constitución de la empresa, cuota inicial del alquiler por un año, pago de licencias, mantenimiento, muebles, joyas de plata y otros gastos. A los primeros que se les ofreció este atractivo proyecto fue a los padres y hermanos, quienes no dudaron en emprender este sueño familiar, teniendo una primera reunión en noviembre del 2014. Se acordó que los diseños de las joyas debían escapar de lo comercial y ofrecer modelos exclusivos por estar en una galería cuyo público eran en su mayoría extranjeros.

El 06 de diciembre del 2014 se inician los trámites de constitución de la empresa y se acuerda la participación de cada uno de los socios según su aporte económico. Víctor 
Gutiérrez con 34\%, Piero Gutiérrez con 36\%, Olyenka Gutiérrez 19\%, Karina Gutiérrez 6\%, Steve Gutiérrez 2.5\% y Mathías Llanos 2.5\%. Ese mismo mes alquiló un local comercial en Av. Petit Thouars 5240. Galería Portada del Sol. Tienda 22 - Miraflores, Lima.

El 05 de enero del 2015 se inscribe a la empresa con RUC 20600033841 y se registra con el nombre Incas Jewelry S.A.C., como empresa dedicada a la fabricación, diseño y comercialización de joyería fina en plata 950, piedras naturales y artículos artesanales. En los datos de la minuta de constitución, Articulo 1, establece que la empresa podrá dedicarse a realizar actividades de diseño, elaboración, fabricación, reparación, importación, exportación, distribución y comercialización, compra y venta de artículos en metales preciosos, artesanía en madera con plata, decoración de prendas de lana y alpaca. Para esta minuta se decide establecer la siguiente participación: Víctor Gutiérrez con 61.5\%, Piero Gutiérrez con 36\% y Steve Gutiérrez con $2.5 \%$, con el fin de agilizar los trámites, por convenio interno entre los socios.

La empresa cuenta con cinco integrantes familiares, siendo el representante legal, el padre y líder de la familia Mg Víctor Gutiérrez, quien a su vez lleva el balance económico, con la ayuda de un contador a quien se terceriza y se le paga de manera mensual. Los demás roles los toman los hijos, siendo Piero Gutiérrez el Gerente de Operaciones, Karina Gutiérrez la Gerente de Tienda y Vendedora, Olyenka Gutiérrez maneja el marketing de la empresa y diseña los modelos según tendencia y Steve Gutiérrez apoya con el traslado de las materias primas. Dos de ellos reciben los beneficios de ley como sueldo por planilla, CTS, seguro, gratificación. Para la empresa también trabajan tres artesanos a quienes se les paga por piezas realizadas, no por jornada de trabajo.

En febrero del 2015 la empresa se presentó en su primera feria internacional "Tucson Gem, Mineral \& Fossil Showcase”, en Tucson, Arizona, llevando solo joyas de plata con piedra y arte de madera con plata. El objetivo de esta participación fue contactar potenciales clientes extranjeros y así ampliar la comercialización exportando a otros países. Lamentablemente no se tuvo los efectos deseados ya que sólo se logró vender los productos llevados a la feria, pero no se pudo establecer ningún contrato con algún cliente extranjero. Se ganó experiencia participando en ferias de joyas y recibiendo a ciertos clientes extranjeros que habían sido contactados previamente desde Lima. Se le entregó muestras y catálogos a este público interesado en estas piezas cuya gema o piedra se muestran en estado natural y no trabajado.

Con el fin de optimizar el cobro del dinero de los clientes que efectuaban sus compras con tarjeta de crédito o débito, en marzo del 2015 la empresa se afilió a Visanet Paypal, 
Visanet Online y Mastercard. Las ventas realizadas con tarjeta Visa representan un $40 \%$ del total, con otras tarjetas es un $20 \%$ y el $40 \%$ restante en efectivo. La mayoría que utiliza tarjeta es de procedencia extranjera. Junto con esta iniciativa se creó una página web http://www.incasjewelry.com/ y un fan page con el fin de que conozcan más acerca de los productos. La venta a través de estos medios se paga con tarjeta o en efectivo (contra entrega al momento de recibir el producto).

En el año 2016, la empresa se afilió a la Cámara de Comercio, con el cual se inició la participación en ferias locales, como Perú Moda Fashion Week, Fibella, entre otras. La empresa ha tenido una serie de contratiempos con la Cámara de Comercio como por ejemplo: Invita a sus eventos a empresas no afiliadas y le quitan participación, teniendo que competir de manera desigual pues al pagar una membresía anual, registrar boletas y facturas en sus ventas disminuye la utilidad de la misma y se hace difícil competir con precios justos. Esto se argumenta en base a la entrevista en profundidad realizada al Gerente General (ver Apéndice A1).

\subsection{Descripción del Negocio}

Incas Jewelry SAC es una pequeña empresa familiar que cuenta con tres empleados contratados y por ser empresa familiar, se suman cinco adicionales que trabajan ad honorem, por puro amor a la empresa. De acuerdo a la entrevista en profundidad realizada al Gerente General (ver Apéndice A1), esta empresa produce y vende joyas de plata, algunas joyas de plata tienen incrustaciones de piedras naturales, en su mayoría de procedencia peruana, seleccionadas cuidadosamente en cabuchones3 utilizando las mejores formas según los diseños que la empresa realiza.

Los diseños son cuidadosamente elegidos por los integrantes de la empresa. En su mayoría son modelos étnicos, haciendo referencia a la cultura peruana, pues al estar ubicado en una galería visitada por turistas, sus principales clientes y visitantes son extranjeros. La empresa produce y vende joyas de plata en dos calidades distintas, variando en la aleación utilizada para su producción:

- Plata 925 , cuya composición es de $92.5 \%$ de plata y un $7.5 \%$ de algún otro metal como el cobre. La venta de este tipo de piezas constituye el $10 \%$ de las ventas totales de la empresa especialmente en productos como cadenas y esclavas de bebe.

\footnotetext{
${ }^{3}$ Cabuchón: O cabujón método para elaborar piedras preciosas o semipreciosas, que consiste en proporcionar una superficie convexa y perfectamente lisa a una piedra, y que resulta ser la más utilizada para crear una joyería masiva. (Reyes, 2010)
} 
- Plata 950, cuya composición es de 95\% de plata y un 5\% de cobre. La venta de este tipo de producto representa un $80 \%$ de las ventas totales de la empresa.

Siendo los aretes lo más vendido.

El arte de la plata se hace de manera artesanal, la empresa compra piñas de plata por kilos para poder tener materia prima que ayude a cumplir con los pedidos. Los diseños se hacen en computadora utilizando software básico como Corel Draw o Photoshop, otros a lápiz y papel y finalmente es impreso. Las piezas más comunes que piden son:

- Calados ${ }^{4}$ : Esta técnica se realiza a mano alzada, consiste en derretir la plata piña 1000 mezclada 0.05 de cobre, luego esta se lamina con el laminador, previamente se ha impreso una hoja con el diseño a calar y con las demás herramientas se va dando la forma curvando apoyado en el yunque (ver Figura 1).

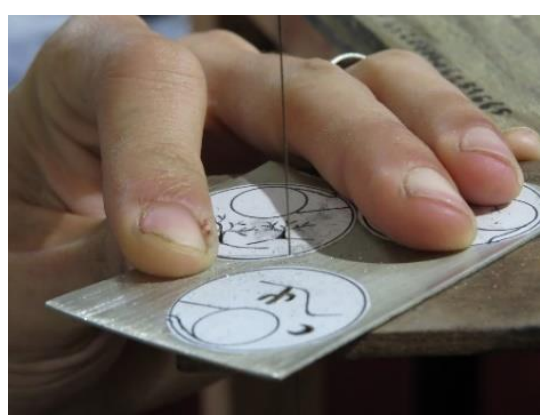

Figura 1. Trabajo de Calado.

- Puntillado: Esta técnica decorativa se realiza con un cincel desde el reverso de la pieza, obteniendo motivos a base de puntos en relieve por el anverso (ver Figura 2).

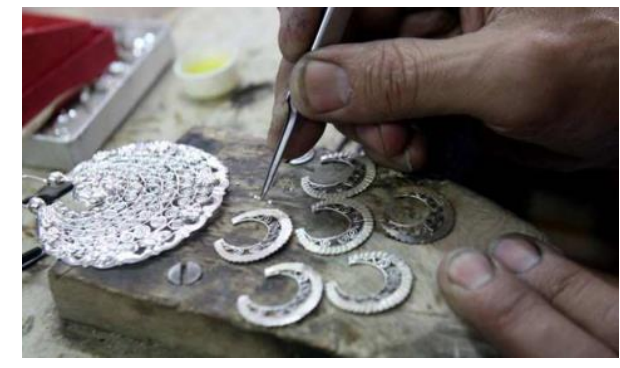

Figura 2. Trabajo de Puntillado en Plata.

- Estampado: Esta técnica decorativa se realiza con un cincel desde el reverso de la pieza, obteniendo motivos a base de puntos en relieve por el anverso (ver Figura 3).

\footnotetext{
${ }^{4}$ Calado de la plata es una técnica de trabajo de este metal que se siguió desarrollando en la época del Virreinato del Perú y que se obtiene mediante el perforado siguiendo los contornos en la superficie de la lámina, no alcanzando la finura y delicadeza de la filigrana, pero corresponde a la misma metodología de trabajo de la plata. (Atribución, 2015)
} 


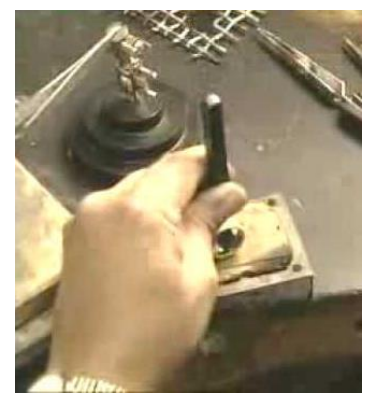

Figura 3. Trabajo de Estampado en Plata.

- Tejido en plata: Esta técnica se realiza a mano también, consiste en fundir la plata y hacerlo hilos luego envolverlos en una broca delgada para luego ser cuidadosamente cortados y con los anillos iniciar el trabajo de tejido según el punto: Peruano, maya, hindú, etc. (ver Figura 4).

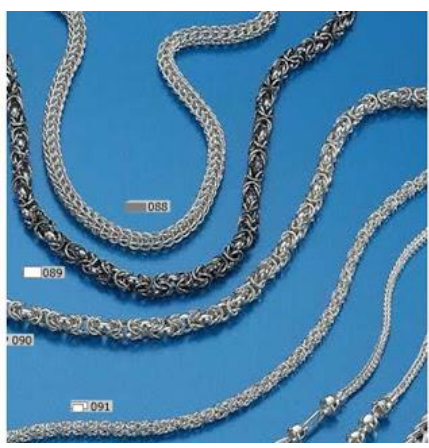

Figura 4. Trabajo de Tejido en Plata.

Incas Jewelry S.A.C realiza una serie de trabajos, solo se ha mencionado las técnicas más comunes, todas ellas se elaboran en la mesa de joyero, hecho de madera, que tiene herramientas, como martillos, cinceles, brocas, limatones, bomba, balanza, etc. Tal como se muestra en figura 5. Si bien el negocio principal de la empresa es la venta de joyas de plata, también se trabaja con oro, artesanía de madera con plata y telares. Se cuenta con proveedores para estos últimos productos y la empresa genera ganancias por la venta de las mismas.

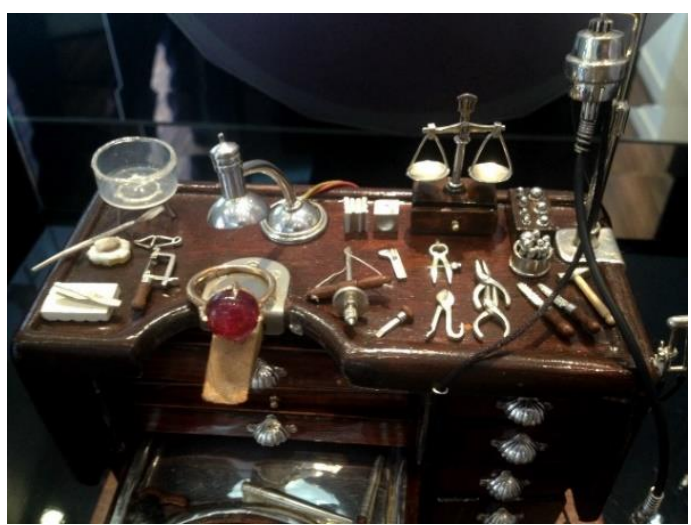

Figura 5. Mesa de Joyero. 
Desde el año 2015 Incas Jewelry es tienda afiliada a la venta de joyas de plata y oro con diamantes de la India. Por la compra de estas joyas que solo se venden a pedido, se entrega un certificado de originalidad al cliente, que establece la garantía y la procedencia del mismo. Los productos vendidos son entregados en cajitas de cartón con una etiqueta que lleva la información de la empresa y su respectiva boleta o factura. Las ventas obtenidas a la fecha no son las esperadas, recién al tercer año está rozando el punto de equilibrio, se podría indicar que los accionistas tuvieron que prestar dinero a la tienda en varias ocasiones para poder pagar los costos fijos, como alquiler, impuestos a la Sunat, dos empleados administrativos, artesanos, mantenimiento del local, etc.

\subsection{Ciclo de Vida del Producto}

En el 2013, David consideró "El ciclo de vida del producto (CVP) es el curso de las ventas y utilidades de un producto durante su existencia" (p.173). Asimismo David también indicó "El concepto del CVP puede describir una clase de producto, una forma de producto o una marca y se aplica de manera diferente en cada caso. Las clases de productos tienen ciclos de vida más largos. Las ventas de muchas clases de productos permanecen en la etapa de madurez durante mucho tiempo. Por el contrario, las formas de productos suelen tener el comportamiento estándar del CVP. Las formas de producto, pasan por una historia regular de introducción, crecimiento rápido, madurez y declinación. El ciclo de vida de una marca específica puede cambiar rápidamente en razón de los ataques y las respuestas cambiantes de la competencia. El concepto del CVP también se puede aplicar a lo que se conoce como estilos, modas y modas pasajeras" (ver Tabla 1).

Para tal efecto, para el presente trabajo se tomó en cuenta los productos bandera que la empresa vende, que en este caso serán las joyas de plata y plata con piedra (ver Apéndice A3). Considerando las etapas del ciclo de vida (Keller, 2009), Incas Jewelry se encuentra en la etapa de crecimiento. Complementando a lo que al autor indica se procede a describir la etapa en la que se encuentra la empresa Incas Jewelry SAC:

\subsubsection{Etapa de crecimiento.}

Como David (2013) señaló "Si el nuevo producto satisface al mercado, entrará en una etapa de crecimiento, en la cual las ventas empezarán a crecer con rapidez. Los adoptadores tempranos seguirán comprando y los compradores tardíos seguirán su ejemplo, sobre todo si escuchan comentarios favorables acerca del producto. Atraídos por las oportunidades de ganancias, los nuevos competidores entrarán al mercado e introducirán nuevas características al producto, con lo cual se expandirá el mercado"... "Las compañías mantendrán sus gastos de promoción al mismo nivel o a un nivel un poco más alto. La educación del mercado 
Tabla 1

Resumen de las Características, Objetivos y Estrategias del Ciclo de Vida

\begin{tabular}{lllll}
\hline $\begin{array}{l}\text { Características } \\
\text { Ventas }\end{array}$ & Introducción & Crecimiento & Madurez & Decadencia \\
Costos & Ventas bajas & $\begin{array}{l}\text { Rápido aumento de } \\
\text { las ventas }\end{array}$ & Ventas máximas & Ventas bajas \\
Utilidades & $\begin{array}{l}\text { Alto costo por } \\
\text { cliente } \\
\text { Negativas }\end{array}$ & $\begin{array}{l}\text { por cliente } \\
\text { Aumento de } \\
\text { utilidades } \\
\text { Adoptadores } \\
\text { tempranos }\end{array}$ & $\begin{array}{l}\text { Bajo costo por } \\
\text { cliente } \\
\text { Altas utilidades }\end{array}$ & $\begin{array}{l}\text { Bajo costo por } \\
\text { cliente } \\
\text { Bajas utilidades }\end{array}$ \\
Competidores creciente & Pocos & $\begin{array}{l}\text { Número estable } \\
\text { que empieza a } \\
\text { disminuir }\end{array}$ & Tardíos \\
& & $\begin{array}{l}\text { Número } \\
\text { decreciente }\end{array}$
\end{tabular}

Nota. Tomado de Marketing Management (p. 280), por P. K. Keller, 2009, New Jersey: Education, Inc., Upper Saddle River. Copyright 2009 por Pearson Education

continua siendo una meta, pero ahora la compañía también debe enfrentar a la competencia. Las utilidades aumentan durante la etapa de crecimiento, a medida que los costos de promoción se distribuyen en un volumen más grande y los costos unitarios de manufactura descienden.” (p216)

Es en esta etapa donde las ventas empiezan a crecer, pero aún no se generan utilidades, los socios tienen que inyectar dinero a la empresa para pagar los gastos de la misma. En su segundo año la empresa decidió incursionar en ferias donde podía mostrar y vender las joyas. La feria más importante en la que participó ese año fue Perú Moda, que se dio lugar en el Pentagonito. Se recibieron cerca de 5000 visitantes en una semana, siendo la mayoría de ellos grandes conocedores de la joyería de plata tanto del extranjero como del Perú. Se compartieron experiencias con otros grandes artesanos y empresas del mismo rubro en una feria en la cual se aprendió mucho sobre las tendencias y como se podía enfocar los diseños. Aquí es donde nace la idea de perfeccionar las joyas de plata con incrustaciones de piedras naturales y spondylus con diseños étnicos. Fue una gran oportunidad de aprendizaje de conocer que los gustos de los extranjeros eran más extravagantes que del público peruano, pues ellos buscan las joyas grandes y las piedras en su mayoría en estado natural incrustadas en dijes, anillos y pulseras. Por ello Incas Jewelry S.A.C amplió los estilos de diseño de las joyas:

- Elaboración de cuñas propias.

- Personalización de diseños existentes.

- Joyas con diseños más complejos en collares y pulseras. 
- Joyas con diseños étnicos los cuales eran del gusto de los turistas extranjeros utilizando en su mayoría incrustaciones de piedras naturales.

En la Tabla 2 se muestra las características de la empresa en su etapa actual del ciclo de vida de su producto, que es la etapa de crecimiento, la que inició en su segundo año de operaciones. Datos extraídos de las entrevistas en profundidad a personal interno (ver Apéndice A).

Tabla 2

Etapa de Crecimiento

\begin{tabular}{ll}
\hline Características & \multicolumn{1}{c}{ Etapa de Crecimiento } \\
\hline Ventas & Las ventas en el segundo año tuvieron un crecimiento del 10\% con respecto al año 2015(año \\
& anterior). Si bien mejoraron de manera mensual con respecto al año anterior, aun no se \\
& llegaba a obtener lo esperado, dato extraído de la entrevista en profundidad al Gerente \\
& General (ver Apéndice A1) \\
& Se dio un costo promedio por cliente, es decir, las ventas realizadas a los clientes se \\
& efectuaban con un margen de ganancia que permitía no castigar los costos de producción del \\
& mismo. \\
Utilidades & En el año 2016, un año después del inicio de sus operaciones, las utilidades fueron \\
& mejorando debido a que se empezó a generar compra de materia prima de primera fuente, ya \\
& no se tercerizaba, los artesanos ofrecían mejores precios por los trabajos realizados. \\
Clientes & Los clientes se fueron adaptando a los precios ofrecidos, sin castigar los costos de \\
& producción que implicaba diseñar y crear a la medida. Empezaron a comprender que el \\
& trabajo era de calidad, porque las joyas obtenidas no se deterioraban y contaban con la \\
& garantía de la tienda, la cual no era necesario porque sus joyas eran bastante buenas, esto \\
& para el caso de clientes locales y para los extranjeros ya no se ofrecía precios basados solo \\
& en la exclusividad, sino que la joya era de buena procedencia y que lo que llevaban \\
& realmente era de calidad, probándose al entregar boletas o facturas. Por otro lado, a favor lo \\
& que se tenía es que la administradora y vendedora de la tienda que es una sola persona, habla \\
& el idioma ingles a la perfección lo que permitía hacer una buena negociación. \\
La competencia fue incrementándose, nuevos competidores ingresaron al mercado con \\
piezas más baratas y de menor calidad en su mayoría. Se sintió el ingreso de mercadería \\
china con bajos costos.
\end{tabular}

Nota. Adaptado de Conceptos de Administración Estratégica (p. 216), por F. David, 2013, México, D.F., México: Prentice Hall. Copyright 2013 por Pearson Education.

\subsection{Estructura Organizacional Actual de la Empresa}

Como Franklin (2009) señaló "Todas las organizaciones, independientemente de su naturaleza y/o campo de trabajo, requieren de un marco de actuación para funcionar. Este marco lo constituye la estructura orgánica, que no es sino una división ordenada y sistemática de sus unidades de trabajo atendiendo al objeto de su creación. Su representación gráfica se conoce como organigrama, que es el método más sencillo para expresar la estructura, jerarquía e interrelación de los órganos que la componen en términos concretos y accesibles." (p.117).

Incas Jewelry S.A.C es una pequeña empresa con una única tienda, sin sucursales, está constituida por tres personas, siendo el Mg. Ing. Víctor Gutiérrez Divizia el Gerente y 
Representante Legal. Piero Gutiérrez y Steve Gutiérrez. En tal sentido se procede a presentar la estructura organizacional, presentando a los integrantes de la empresa y de la misma manera las funciones que cada miembro principal realiza, en una representación gráfica de naturaleza micro administrativo ${ }^{5}$ y de presentación vertical $^{6}$ (ver Figura 6).

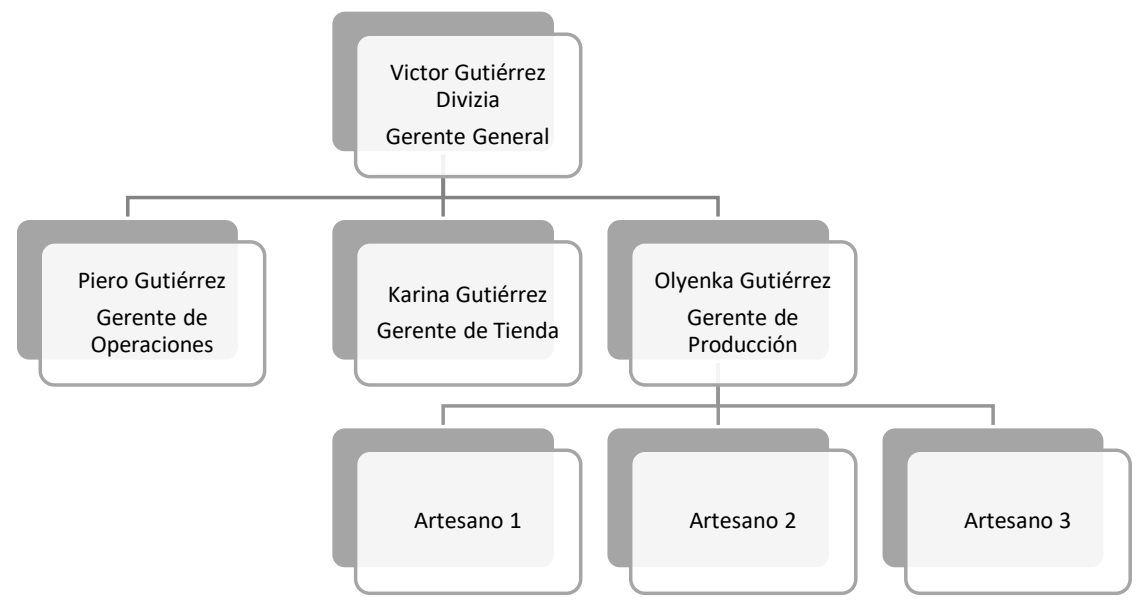

Figura 6. Organigrama de Incas Jewelry SAC

Funciones principales:

Esta información fue registrada de las entrevistas en profundidad al personal interno de la empresa. Cada uno tiene funciones y algunas no corresponden a su cargo. La información de funciones del Gerente de Producción las hizo un integrante del presente trabajo quien tiene ese rol en la empresa por lo cual no se hizo entrevista. Asimismo, se procede a colocar las funciones de cada uno de los gerentes de la empresa:

Gerente General y Representante Legal: Tomado del Apéndice A1.

- Dirección, administración del negocio.

- Vigilar el cumplimiento de las normas básicas de la empresa.

- Planificar los objetivos generales y específicos de la empresa a corto y largo plazo.

- Controla las actividades y acciones realizadas dentro de la empresa.

- Fomenta el buen clima laboral.

- Fomenta la responsabilidad social en las acciones de los trabajadores.

- Analiza los problemas administrativos, financieros y contables.

- Realiza los cálculos financieros para el desembolso de dinero.

\footnotetext{
${ }^{5}$ Microadministrativo: Corresponden a una sola organización, pero pueden referirse a ella en forma global o a alguna de las unidades que la conforman. (Fincowsky, 2009)

${ }^{6}$ Vertical: Presentan las unidades ramificadas de arriba hacia abajo a partir del titular en la parte superior, desagregando los diferentes niveles jerárquicos en forma escalonada. Son los de uso más generalizado en la administración, por lo cual se recomienda su uso en los manuales de organización. (Fincowsky, 2009)
} 
- Coordina con las demás áreas con la finalidad de reparar los desperfectos de la empresa.

- Evalúa y firma los acuerdos comerciales propios de la empresa.

Gerente de Tienda: Tomado del Apéndice A2.

- Buscar oportunidades de ventas, prospectando clientes.

- Llevar el control de las ventas y de caja chica.

- Responsable de la provisión de materiales administrativos, como boletas, facturas, guía de remisión.

- Mantener la tienda aseada.

- Informar sobre los cambios de tendencia de los clientes.

- Coordinar con los servicios de Courier la entrega de los productos.

- Organizar los eventos y ferias a las que la empresa es invitada.

Gerente de Operaciones: Tomado del Apéndice A4.

- Representación de marcas a través de la tienda.

- Buscar nuevos mercados en el extranjero.

- Solicitar los mejores presupuestos de la materia prima.

- Verificar la procedencia y calidad de los insumos.

- Realizar los contratos con las empresas e-commerce como Linio, Ofertop y otros.

- Realizar la publicación de las promociones en Google.

Gerente de Producción:

- Diseñar piezas a solicitud del cliente y controlar los insumos utilizados.

- Mantener la correcta utilización de la materia prima y evitar mermas.

- Proponer políticas de mejora en la producción de las piezas hechas en plata.

- Inspeccionar el área de trabajo en taller, cumpliendo las medidas de seguridad necesarias y cuidar las herramientas de trabajo y supervisar su correcto funcionamiento.

- Coordinar con el Gerente de Logística para la provisión de materiales utilizados y la compra de nuevos.

- Responsable del diseño de piezas exclusivas de la tienda.

- Supervisar a los artesanos sobre las tareas solicitadas.

- Cumplir con los plazos de entrega de piezas realizadas en los pactos propuestos.

- Generar una guía de trabajo para que la administradora sepa que trabajos deben realizarse. 
- Registrar y almacenar los productos nocivos y de alta peligrosidad.

\subsection{Situación de Mercado y Financiera Actual de la Industria}

No existen estudios actualizados sobre el negocio de joyería en el Perú, la información en su mayoría es sobre la exportación de las joyas de plata. Basada en experiencia propia de la empresa de las ferias locales sobre joyerías y las tiendas aledañas a la tienda se logra establecer que existe un público que le gusta lucir joyas de plata, a pesar de ser un poco más caras que la bisutería ${ }^{7}$ fina. Esto hace sentido con el deseo de las personas por comprar joyas de plata que duran más.

Julio (2017) proyectó que para fines del 2016 las exportaciones sumarían entre US\$ 85 millones a US\$ 90 millones, lo que implicó un crecimiento a lo alcanzado el 2015 (US\$ 81.4 millones). El empresario proyectó que las ventas al exterior de las joyas peruanas hechas a base de plata empiecen a subir en el segundo semestre del año, promovido por las fiestas navideñas. A nivel sudamericano, el Perú ocupa el tercer lugar en la exportación de joyas. El primer lugar es de Brasil y el segundo de Colombia. Es importante mencionar que el Perú es el segundo productor de Plata en el mundo, siendo México el primero y China el tercero, según el ranking de los principales países productores de plata a nivel mundial en 2017 (en toneladas métricas).

En 2018, Hochschild Mining’s Pallancata ${ }^{8}$ señaló "Perú es hogar de una de las minas más grandes en la esfera global y de las mayores productoras de plata a nivel global”. La producción de plata en Perú ha aumentado aceleradamente desde el 2012, donde destacaron por contar. Omi Argent, empresa que comercializa joyas de plata en un estudio que ellos pagaron determinaron que Perú es el país con las reservas más grandes del mundo y que la joyería mueve unos US \$57 millones al año en el mercado local. Asimismo, su Informe de Seguimiento de Mercado Joyero, el perfil de la consumidora peruana de joyas es una mujer independiente y emprendedora del NSE B/C, entre los 21 y 60 años. Señala también señala que los peruanos se alejan cada vez más de la bisutería, dado que una vez que el producto pierde el atractivo, la inversión se pierde. El consumidor es cada vez más consciente que las joyas de plata mantienen su valor.

\footnotetext{
${ }^{7}$ Bisutería: Industria que produce objetos de adorno, hechos de materiales no preciosos. (Repositorio Promperu, 2017)

${ }^{8}$ La propiedad Pallancata, rica en plata y oro, ubicada en el departamento de Ayacucho, en el sur del Perú, aproximadamente a 160 kilómetros de la operación Arcata. En Hochschild tuvo una participación controladora del $60 \%$ en International Minerals Corporation ("IMZ"). Tras la compra de IMZ, Hochschild posee el $100 \%$ de la operación.
} 


\section{Capítulo III: Formulación de Visión, Misión y Valores de la Empresa}

En el presente capítulo se presenta la visión actual de la empresa, otorgada por el Gerente General de la empresa Incas Jewelry SAC, se procedió a analizarla para luego proponer una visión, la cual fue revisada y aprobada por el Gerente General puesto que estaba alineada a la empresa. Con esta visión aceptada se procedió a revisar la misión, la cual fue analizada para luego proponer otra. Con estos datos se analizaron los valores de la empresa y se propusieron adicionales. Finalmente se alinearon la visión, misión y valores de la empresa Incas Jewelry SAC.

\subsection{Visión}

\subsubsection{Visión actual de la empresa.}

Esta visión fue proporcionada por el Gerente General de la empresa Incas Jewelry S.A.C.

"Posicionar en lugar preferente la joyería y artesanía peruana en el mercado global."

\subsubsection{Análisis de la visión actual.}

La visión actual no hace referencia directa a lo que la empresa busca convertirse. Es una apreciación que está más vinculada al mercado y a la industria local, fue realizada sin ningún tipo de indicadores o variables. En este sentido, David (2013), señaló “Una declaración de visión debe responder esta pregunta fundamental: “¿En qué queremos convertirnos?”. Una visión clara sienta las bases para desarrollar una declaración de misión detallada". (p. 45). Por ello es necesario reformular la visión actual de la empresa que carece de ciertos componentes que permita conocer las bases primordiales para luego declarar la misión.

\subsubsection{Matriz de la visión propuesta para la empresa.}

Para esta visión se adaptó los elementos sugeridos por David (2009) para buscar que esta cumpla con el contenido adecuado (ver Tabla 3).

\subsubsection{Visión propuesta.}

Se presenta la visión propuesta:

"Ser reconocida como una empresa referente en la producción de joyería de plata y gemas nativas en el Perú." 
Tabla 3

Matriz de la Visión Propuesta para la Empresa

\begin{tabular}{llll}
\hline \multicolumn{1}{c}{ Elementos a conocer } & $\mathrm{Si}$ & No & \multicolumn{1}{c}{ Porque } \\
\hline $\begin{array}{l}\text { Define la ubicación de la empresa en } \\
\text { relación con otras empresas similares }\end{array}$ & $\mathrm{x}$ & - & $\begin{array}{l}\text { En la vanguardia de las pequeñas empresas } \\
\text { artesanales dedicadas a la platería }\end{array}$ \\
$\begin{array}{l}\text { Describe el ámbito geográfico a nivel } \\
\text { nacional o internacional }\end{array}$ & $\mathrm{x}$ & - & $\begin{array}{l}\text { El Perú es el territorio de las antiguas culturas } \\
\text { pre incas y contiene ricos recursos minerales. } \\
\text { Define la ambición de la empresa en } \\
\text { relación con el sector con el que opera }\end{array}$ \\
\hline
\end{tabular}

Nota. Los $\mathrm{x}$ indican si se cumple el elemento y los guiones que no cumplen. Adaptado de Conceptos de Administración Estratégica (p. 45), por F. David, 2013, México, D.F., México: Prentice Hall. Copyrigth 2013 por Pearson Education.

\subsection{Misión}

\subsubsection{Misión actual de la empresa.}

Esta misión fue otorgada por el Gerente General de la empresa Incas Jewelry S.A.C. "Contribuir al desarrollo de la cultura y economía agregando valor artístico a la producción de metales preciosos y piedras nativas del Perú."

\subsubsection{Análisis de la misión actual.}

La misión actual no incluye todos los elementos de la misión propuesta. Como David (2013) señaló "La declaración de la misión identifica el alcance de las operaciones de una empresa en términos de producto y mercado" (p.10) por lo cual requiere un rediseño para un mejor pronunciamiento de actitudes y perspectivas.

\subsubsection{Elementos de la misión propuesta para la empresa.}

En la tabla propuesta por David (2013) se analizó los elementos para plantear la nueva misión (ver Tabla 4).

\subsubsection{Misión propuesta.}

Para la misión propuesta se analizaron los elementos propuestos en el punto anterior. "Ofrecer joyas de plata y gemas nativas que marquen tendencia usando diseños de la cultura peruana."

\subsection{Valores}

\subsubsection{Valores actuales de la empresa.}

En esta parte se procede listar los valores de la empresa Incas Jewelry S.A.C obtenidos en base a la información brindada por el Gerente General.

- Responsabilidad y compromiso: Desarrollar y mantener una conducta en el cual se respete los derechos de las personas. Cumplir con las leyes y normas que la sociedad exige. 
Tabla 4

Elementos de la Misión Propuesta para la Empresa

\begin{tabular}{|c|c|c|c|}
\hline Elementos a conocer & $\mathrm{Si}$ & No & Porque \\
\hline Hace referencia a los clientes & $\mathrm{x}$ & - & $\begin{array}{l}\text { Porque es importante que los clientes tengan un } \\
\text { grado de lealtad con la empresa. }\end{array}$ \\
\hline Referencia al producto y servicio & $\mathrm{x}$ & - & $\begin{array}{l}\text { La empresa produce y comercializa joyas de } \\
\text { plata a precios razonables y confiables. }\end{array}$ \\
\hline Toma en cuenta su mercado & $\mathrm{x}$ & - & $\begin{array}{l}\text { Indica el interés por ingresar a un segmento más } \\
\text { grande. }\end{array}$ \\
\hline Tecnología & $\mathrm{x}$ & - & $\begin{array}{l}\text { Es mayormente utilizada en el marketing y } \\
\text { comercio electrónico. }\end{array}$ \\
\hline $\begin{array}{l}\text { Se preocupa por la supervivencia, } \\
\text { crecimiento y rentabilidad }\end{array}$ & $\mathrm{x}$ & - & $\begin{array}{l}\text { Adecua a través de una gestión rentable } \\
\text { productos que satisfacen al cliente. }\end{array}$ \\
\hline Revela alguna filosofía & $\mathrm{x}$ & - & $\begin{array}{l}\text { La empresa maneja como filosofía de la tienda } \\
\text { "Calidad compartida con la cultura inca" }\end{array}$ \\
\hline Mantiene un auto concepto & $\mathrm{x}$ & - & $\begin{array}{l}\text { Mantiene mejora continua en todos los procesos } \\
\text { de producción y atención al cliente }\end{array}$ \\
\hline Se preocupa por la imagen publica & $\mathrm{x}$ & - & $\begin{array}{l}\text { Si porque rescata la joyería precolombino y } \\
\text { ancestral del Perú }\end{array}$ \\
\hline Se preocupa por lo empleados & $\mathrm{x}$ & - & $\begin{array}{l}\text { Si porque al ser una organización formal los } \\
\text { empleados están en la aplicación de la } \\
\text { legislación respetando sus derechos. }\end{array}$ \\
\hline
\end{tabular}

Nota. Las x que si conoce el elemento y el guión que no lo conoce. Adaptado de Conceptos de Administración Estratégica (p. 45), por F. David, 2013, México, D.F., México: Prentice Hall. Copyrigth 2013 por Pearson Education.

- Innovación: Buscar de manera constante nuevos diseños exclusivos diseñados a la medida y pedido del cliente, para que sea beneficioso para la empresa y cliente.

- Cordialidad: Mantener un ambiente de cordialidad y buen trato con los trabajadores para que ellos puedan transmitir esta cultura a los clientes.

- Cumplimiento: Cumplir con los compromisos en los tiempos acordados con el personal y clientes, respetando las fechas indicadas.

- Calidad: Trabajar con materia prima de calidad, de buena procedencia siguiendo el estándar establecido de originalidad de los diseños para que el cliente sienta la satisfacción de haber comprado algo de calidad

- Transparencia: Establecer políticas de confidencialidad con los empleados que son tercerizados, para que respeten la exclusividad de los diseños de la empresa.

\subsubsection{Análisis de los valores actuales.}

En este punto detallamos la composición de cada uno de los valores extraídos del documento resumen ejecutivo de la empresa.

- Responsabilidad y compromiso: Lo esperado con este valor es que los empleados y artesanos sean responsables y conscientes en su hora de ingreso, entrega de productos y sobretodo respeten el diseño propuesto por el cliente. 
- Innovación: Lo que se busca es que los clientes sepan que la empresa ofrece siempre exclusividad y que en cada visita encontraran productos similares, pero con cambios que permitan volver a realizar la compra.

- Cordialidad: Tratar a los empleados de manera amable y educada, replica de alguna manera la forma en como ellos podrán tratar al cliente.

- Cumplimiento: Lo que se busca es siempre entregar los productos en los plazos establecidos en los contratos realizados para que el cliente note la seriedad del mismo, para ello siempre se estima 3 días adicionales de plazo de entrega para poder cumplir con lo pactado.

- Calidad: Lo que se busca en este valor es que el cliente tenga la certeza de que el producto realmente tenga la pureza en la materia prima entregada.

- Transparencia: Lo que se espera es que los artesanos respeten la exclusividad del diseño, pero en ocasiones por temas de profesionalismo se terceriza, es difícil que ellos no copien estos diseños y sean utilizados en sus tiendas.

\subsubsection{Elementos de los valores propuestos para la empresa.}

Con los elementos existentes y entregados por la empresa, se procedió a listar y describir los elementos de los nuevos valores propuestos para Incas Jewelry S.A.C:

- El bien propio: La búsqueda del bien propio en la escala de valores permite considerar la armonía que se desea establecer internamente y que de alguna manera es transmita a los clientes.

- La competitividad: Conocer la competencia ayuda a la empresa fortalecer la oportunidad es generadas para el bienestar de la empresa.

- Lo racional: Es importante buscar la racionalidad en cada una de las operaciones, la búsqueda de la verdad trabaja junto en esta, asumiendo siempre retos que sean responsables.

- El control: Mantener el control interno permite que los empleados trabajen con normas pautadas, considerando que ellos puedan generar ideas a favor de la empresa, pero siempre manteniendo un orden en la ejecución de las mismas.

- La eficiencia: Debe formar parte de la definición de la empresa y así lograr objetividad.

- La imagen: Tanto a nivel organizacional como personal mantener una buena imagen es importante. Lo que los empleados, clientes, proveedores piensen de la empresa juega un papel importante, pues es como te ven y esto genera gran impacto. 


\subsubsection{Valores propuestos.}

En base a lo revisado en el punto anterior se propuso los siguientes valores que se considera como aporte positivo a la cultura de la empresa, añadiéndose a los actuales:

- Autocritica: Es importante saber rectificarte cuando te has cometido errores, luego de una jornada de trabajo, es importante reconocer los errores para poder mejorar y con la experiencia adquirida continuar.

- Aprendizaje: Con el fin de poder evolucionar es necesario está en continua capacitación y/o aprender de las experiencias de empresas similares

\subsection{Alineamiento Estratégico de la Visión, Misión y Valores de la empresa}

Un alineamiento estratégico nos ayuda a comprender que las organizaciones no es suficiente elaborar un plan estratégico ya que la idea es hacerlo operativo, manteniendo una visión compartida, cuya misión se trabaja en el día a día siguiendo los lineamientos de los valores. Como Drucker (2006) estableció "Las herramientas para que pudieran verbalizar los motores esenciales: lo que quieren; lo que son; a qué se dedican; cuáles son sus sueños; hacia dónde quieren llegar y de qué manera. Por ello, se procedió a elaborar la Tabla 5:

Tabla 5

Alineamiento Estratégico de la Visión, Misión y Valores de la Empresa

\begin{tabular}{|c|c|c|c|}
\hline & Visión & Misión & Valores \\
\hline Definido por & Lo que queremos ser & ¿Por qué existimos? & ¿En que creemos? \\
\hline Lo propuesto & $\begin{array}{l}\text { Líder en el diseño, } \\
\text { producción y } \\
\text { comercialización de } \\
\text { joyas con motivos } \\
\text { precolombinos }\end{array}$ & $\begin{array}{l}\text { Buscamos la identidad de los } \\
\text { clientes con las antiguas } \\
\text { culturas incas ofreciendo } \\
\text { colecciones que marquen } \\
\text { tendencias actuando con } \\
\text { transparencia y } \\
\text { responsabilidad social. }\end{array}$ & $\begin{array}{ll}\text { - } & \text { Responsabilidad y } \\
\text { compromiso: } \\
\text { Innovación } \\
\text { - } \text { Cordialidad } \\
\text { - Cumplimiento } \\
\text { - Calidad } \\
\text { - Transparencia }\end{array}$ \\
\hline
\end{tabular}

\footnotetext{
Cuenta con

planificación que

permita la

consecución de los

objetivos

Optimiza recursos y

añade innovación

Se percibe lo que se

desea alcanzar

Encamina los

esfuerzos de las

personas que ahí

trabajan

Se acerca a la cultura

de la empresa que

permita cumplir con

los objetivos

estratégicos
}

$\mathrm{Si}$

$\mathrm{Si}$

$\mathrm{Si}$

Nota. Adaptado de Conceptos de Administración Estratégica (p. 45), por F. David, 2013, México, D.F., México: Prentice Hall. Copyrigth 2013 por Pearson Education. 


\section{Capítulo IV: Análisis Externo}

Para este capítulo se realizaron entrevistas en profundidad a expertos en la industria de la joyería, como: Mincetur, Joyas M\&F, Spondylus y Gremio de Artesanos del Perú. Con la intención de analizar los aspectos político, económico, legal, cultural, tecnológico y ecológico, se consideraron solo aquellos que afectan a la industria. Asimismo, se verá el impacto en los clientes, efecto en la empresa. Con los análisis se procede a determinar las oportunidades y amenazas, las cuales están detalladas en cada uno de los aspectos mencionados. Para el desarrollo de este capítulo se realizó entrevistas en profundidad las que podrán ser encontradas en los apéndices con sus respectivas guías y cuestionarios, las transcripciones están en un anexo aparte y que están disponibles a solicitud de quien lo requiera.

\subsection{Tendencias de las Variables del Entorno}

Como David (2013) señaló "Los factores externos y la industria en la que compite ejercen una influencia más fuerte en el desempeño de la empresa que los asuntos funcionales internos relativos al marketing, las finanzas, etc.” (p. 65). Los datos que se están publicando en el presente trabajo son aquellos relacionados al entorno externo en lo político, económico, legal, cultural, tecnológico y ecológico impactan a la empresa para así determinar las acciones a tomar. Para este capítulo se realizaron entrevistas en profundidad a expertos de la industria (ver Apéndice A). De estos datos se pudo tomar las oportunidades y amenazas en la industria de la joyería.

\subsubsection{Análisis político-gubernamental.}

El presente análisis se basa en las variables como corrupción y gobernabilidad.

- Gobernabilidad: El Perú sufrió una crisis política durante 2017-2018, ocasionada por la vacancia del expresidente Pedro Pablo Kuczynski. Esto impactó la situación política y social del país trayendo con consecuencia la asunción del Primer Vicepresidente de la Republica Martin Vizcarra por encontrarse en la línea de sucesión. Algo que se mantiene de gobiernos anteriores son los acuerdos comerciales con diversos países llamados TLC. Estos tratados también impactan a la industria joyera debido a las oportunidades y amenazas que se presentan por la apertura a mercados internacionales. En este punto se encuentra una oportunidad de negocio "O1. Existencia de TLC con países con alto potencial de compradores y proveedores", pues en las entrevistas en profundidad realizadas a los expertos de la industria, se indica que la joyería peruana está en auge con los tratados firmados 
como el TLC originando que varias empresas extranjeras marquen territorio con respecto a la compra y venta de joyas de plata peruana.

\subsubsection{Análisis económico}

El presente análisis se basó en las variables como PBI, Inflación, Impuestos y Empleo

- PBI: Según el reporte del Banco Central de Reserva del Perú - BCRP, (2018) la proyección del PBI será 4.0\%, manteniéndose la misma para el 2019 impulsada por una mayor inversión pública asociada al gasto de reconstrucción. En 2017, BCRP señaló que "el gasto privado continuara recuperándose por el mayor dinamismo de la inversión y el consumo, en respuesta al impacto positivo de los términos de intercambio". En este punto se encuentra una oportunidad "O2. Alta demanda de compradores de joyas de plata", ya que vemos que los niveles de consumo público se vienen incrementando desde el 2017 con una tendencia de crecimiento hacia el 2019.

- Factores de Importación y Exportación: En 2018, BCRP en un reporte informó “Los niveles de exportación bajaron comparado con el 2016 y 2017 donde los niveles estaban en $9.5 \%$ y $7.2 \%$ respectivamente, podemos ver que según la proyección al 2018 y el 2019 es de $3.2 \%$ y 3.6\% con una tendencia a la subida". Sobre los niveles de exportación de la plata peruana existes un gran nivel de demanda de los mercados europeos y asiáticos históricamente. A partir de dicha información es que se encuentra la siguiente oportunidad: "O1. Existencia de TLC con países con alto potencial de compradores y proveedores" y "O3. Existencia de importadores de Europa y Asia" pues impacta en las importaciones.

- Patrones de Consumo: De acuerdo al conocimiento y la experiencia en este mercado, es conocido el comportamiento de turistas extranjeros quienes casi siempre consideran adquirir una joya peruana además de artesanías con motivos étnicos (incaicos) gastando cantidades de dinero considerables valorando más la calidad y el diseño del producto antes que el costo del mismo. Es así que se considera la siguiente oportunidad: "O4. Alto poder adquisitivo de los clientes extranjeros".

- Mercado comercial: La industria joyera en el país como en todo el mundo está lleno de diversos jugadores tanto los grandes proveedores que cuentan con minas propias desde donde extraen sus metales y que aparte de distribuir a otras empresas más pequeñas también tienen posibilidad de exportar directamente sus productos en grandes cantidades. Es en este contexto que se hallan tres amenazas: "A1. 
Presencia de mayoristas", existe una gran presencia de proveedores; "A2.

Existencia de productos sustitutos", venta en menor grao como el oro, diamante, piedras preciosas, ingreso de joyas provenientes de la China y Europa “A3.

Economía de escala de las grandes tiendas", por las promociones ofrecidas por las grandes tiendas de la industria joyera.

- Inflación: Según el BCRP (2018) se revisó al alza el crecimiento global en 2018 y 2019 por mejores condiciones en el mercado laboral en las economías desarrolladas y mayores precios de los commodities. En este punto se encuentra una amenaza “A4. Alza de precio de los insumos”, pues (BID, 2017) señala que el sector de la minería y agrícola serán los más beneficiados sumándose a que estas están siendo continuamente innovadas en sus procesos de producción, lo que mejora el negocio de las joyerías al ser la plata el insumo principal que se utiliza. Con esto los más beneficiados son las empresas grandes o reconocidas marcas, ya que de esta manera generan diversas promociones al consumidor. Esta información es confirmada en las entrevistas en profundidad realizada a expertos del gremio de artesanos (ver Apéndice B).

- Impuestos: El régimen de las pequeñas empresas que entró en vigencia en enero del 2017 buscó incentivar la formalización de las empresas, sin embargo, se ha dado un efecto contrario. Este régimen paga tasas de impuesto a la renta de $10 \%$ (para las primeras 15 UIT de renta anual) y 29.5\% (para el excedente de las 15 UIT); se paga IGV y se requiere llevar contabilidad. El pago de impuestos afecta a las pequeñas empresas, pues les deja poca utilidad. De esto se aprovechan las empresas informales que logran crecer un poco más pues el ingreso es mayor. Por otro lado, un beneficio importante de estar constituidas y al día en sus impuestos es poder participar de ferias locales o internacionales y estar inscritas en organizaciones que promueven a las pymes como Cámara del Comercio. En este punto también debemos mencionar que los altos impuestos y precios por alquiler de stand dificultan la participación de las pymes en las ferias de la cámara de comercio. Debido a eso detectamos la amenaza "A5. Limitado apoyo de la cámara de comercio" que refiere el alto cobro impuesto por la Cámara de Comercio, no solo por cada evento, sino que obliga a pagar impuestos adicionales por la venta de los productos realizados en dichos eventos.

- Empleo: En 2017, El Peruano consideró “La producción de joyas de oro, plata y otros genera en el país alrededor de 30,000 puestos de trabajo directos y más de 
20,000 indirectos. Es una fuente de empleo descentralizado”. Esto significa que esta industria está creciendo notablemente, pues en cuatro años ha duplicado los puestos de trabajo, representando un gran salto a la modernidad, lo que permite crear nuevas técnicas para desarrollar mejor calidad en los productos. La producción artesanal está asociada a la economía familiar, creando un efecto multiplicador en la economía, existiendo una creciente demanda en mercados de alto poder adquisitivo. Como Promperú (2017) indicó que en el sector de la artesanía se encuentran involucrados alrededor de 1 millón de personas. Es importante destacar que en estas cifras también están incluidos los mayoristas quienes venden en volúmenes grandes generando ingresos altos, por ello se toma en cuenta la amenaza “A1. Presencia de mayoristas”. Esto es debido al impacto que generan en el mercado ya que pueden ofrecer mejores precios a vender en grandes cantidades, cosa que las pequeñas empresas y minoristas no pueden hacer.

\subsubsection{Análisis legal.}

El presente análisis se basó en las variables como legislación y certificación. No existe una ley que afecte directamente a la industria de la joyería, pero un marco legal de constitución y veracidad de los productos que ofrecen forman un aspecto importante en la venta de las mismas.

- Legislación: Para este análisis se tomó en cuenta las normas legales a las que están sujetas las pymes, como es el caso de Incas Jewelry S.A.C. y que mencionamos en el siguiente párrafo. Según lo escrito en las Normas Legales Pymes (Peruano, 2008), esta es una empresa que a la fecha cumple con todas las reglas establecidas, llevando dos libros contables firmados con un contador que trabaja como externo para el negocio.

“Artículo 124․- Libros y Registros Contables Los sujetos del presente Régimen están obligados a llevar un Registro de Compras y un Registro de Ventas de acuerdo con las normas vigentes sobre la materia."

“Artículo 124-A .- Declaración Jurada Anual Los sujetos del presente Régimen anualmente presentarán una declaración jurada la misma que se presentará en la forma, plazos y condiciones que señale la SUNAT. Dicha declaración corresponderá al inventario realizado el último día del ejercicio anterior al de la presentación."

“Artículo 65\%.- Los perceptores de rentas de tercera categoría cuyos ingresos brutos anuales no superen las 150 UIT deberán llevar como mínimo un Registro de 
Ventas, un Registro de Compras y Libro Diario de Formato Simplificado de acuerdo con las normas sobre la materia. Los demás perceptores de rentas de tercera categoría están obligados a llevar contabilidad completa.”

Mediante Ley $\mathrm{N}^{\circ}$ 28015, publicada el 3 de julio de 2003, se aprobó la Ley de Promoción y Formalización de la Micro y Pequeña Empresa; ley que ampara a las microempresas como lo es Incas Jewelry S.A.C. Muchas empresas optan por la informalidad precisamente porque no tienen que pagar impuestos altos, por ello se encuentra la amenaza "A6. Alta informalidad en el sector"

En 2017, INEI señaló:” La tasa de nacimientos de empresas que relaciona las unidades económicas creadas en el IV Trimestre de 2017 con el stock empresarial representó el 3,0\% del total, mientras que la tasa de mortalidad empresarial fue de 1,5\% en el mismo período.” Formalizar una empresa y mantener un estatus legal en ellas ha ido creciendo dando oportunidades de mejorar la economía del país, generando de esta manera mucha competencia, siendo Miraflores y Centro de Lima los distritos donde más se vende joyas de plata.

- Certificación: Las certificaciones son a nivel internacional, son requisito base para exportar manteniendo los estándares mínimos de certificación. Los sellos distintivos deben cumplir las Normas Técnicas Peruanas (NTP) (Mincetur, 2015): 399.500; 399.501; 399.502; 399.503; ISO 9202, ISO 11426, ISO 11427. Estas normas establecen la determinación de los minerales en aleaciones para metales preciosos en platería, inspecciones, rotulados y manual de buenas prácticas, así lo señala un experto en la industria (ver Apéndice A5). Los industriales joyeros están buscando una certificación del Instituto Nacional de Calidad (Inacal). ${ }^{9}$ Justamente a finales del 2017 Julio Pérez, presidente del Comité de Joyería y Orfebrería de Adex, (2017) señaló que el gremio está trabajando de la mano con el Instituto de la Calidad (Inacal) y el Indecopi para sacar adelante un sello propio: un certificado que garantice que el producto elaborado y comprado cuenta con la cantidad de quilates y la pureza que se está ofreciendo. Este documento brindará garantía y seguridad al joyero de que su empresa ha seguido procedimientos rigurosos y podrá así competir en igual de condiciones con otros productores de joyas en el mundo, que le permitirá aumentar sus ventas. Con esta certificación se proyecta

\footnotetext{
9 INACAL: Organismo Público Técnico Especializado, adscrito al Ministerio de la Producción, con personería jurídica de derecho público, y autonomía administrativa, funcional, técnica, económica y financiera.
} 
que las joyerías que emprendieron de manera formal tomaran un gran impulso, puesto que los clientes tendrán la certeza de comprar una joya de plata de calidad, lo importante según señala Promperu (2017) es que las personas no solo optaran por adquirir este bien con el fin de lucirlas, sino de comprarlas orientando esta adquisición al ahorro, inversión y dinero.

Uno de los beneficios de tener certificación es que te da pie a generar alianzas con proveedores formales y así no perder la calidad de los productos, actualmente las empresas de marcas reconocidas ya cuentan con esta certificación permitiéndoles posicionarse no solo en mercado nacional sino de manera internacional, es por ello que aquí se encuentra la amenaza "A7. Presencia de grandes marcas", pues son aquellas que logran generar un buen volumen de ventas debido a la posibilidad de obtener certificaciones. Y a la par genera una oportunidad de negocio "O5. Existencia de ferias ", debido a que las empresas que cuentan con certificaciones de sus productos tienen mayor preferencia en los consumidores sobre todo en ferias promovidas por diversas instituciones como Cámara de Comercio.

\subsubsection{Análisis cultural.}

El presente análisis se basó en la variable moda, pues según lo señalado por la Gerente de la Tienda, la moda registra altos valores de sofisticación y el lucir una joya de plata puede variar desde su uso diario como para ocasiones especiales. Incluso la gente prefiere regalar joyas de plata.

- Estilos de vida: En el Perú existen diversas líneas artesanales; al norte del país, Piura, es uno de los pioneros en el trabajo de plata utilizando la técnica de la filigrana, que con hilos de plata marcan cuidadoso tejido de plata y son muy apreciados por todos los clientes. Catacaos, es la capital artesanal de Piura, hay varios ejemplos: el trabajo en sapote, cuero y madera; el burilado; la alfarería y, por supuesto, la filigrana y el sombrero de paja toquilla, los dos últimos reconocidos como Patrimonio de la Nación (ver Apéndice A6).

En 2016, La Universidad de Piura señaló "Desde el 2010 la filigrana es Patrimonio de la Nación por ser una "expresión de una tradición sumamente antigua, original de este distrito, transmitida por línea familiar, la calidad y finura del trabajo artesanal, que le ha merecido reconocimiento dentro y fuera del país". Este testimonio representa que los clientes continúan teniendo una tendencia al uso de plata y buscan diseños exclusivos, y desde hace unos años estos diseños los desean con incrustaciones de piedras nativas, estudios realizados 
por Ilaria Joyas (2015) así lo confirman. Existe una tendencia por el uso de joyas de plata y oro, no solo por personas adineradas sino por aquellas que por darse un pequeño gusto lo compran. Existiendo un público que también opta por la bisutería por tener un costo bajo, en este caso las joyas chinas han ingresado con fuerza al mercado peruano. Existiendo una tendencia a la innovación, lo cual genera una producción de colecciones nuevas. Obteniendo de esta manera la oportunidad "O3. Alta demanda de compradores locales de joyas de plata"

\subsubsection{Análisis tecnológico.}

El presente análisis se basa en las variables Innovación y Desarrollo, variable importante porque sin estas no se puede trabajar en las joyas, puesto que los clientes no mantienen en mente el mismo diseño, siempre desean lucir joyas con diseños exclusivos.

- Innovación y Desarrollo: La plata es un metal blando, lustroso y maleable, demasiado blando para ser utilizada en estado puro, por lo que se emplea en aleación con otros metales nobles. La plata de los joyeros es una aleación de $80 \%$ de plata y $20 \%$ de cobre. En estado puro funde a $954^{\circ} \mathrm{C}$. Si bien el arte de la plata es trabajada de alguna manera en forma artesanal y que muchas piezas se crean a mano, algunas veces por la complejidad del diseño y otras porque no es conveniente hacer un cuño para una sola pieza, esto sería muy caro.

El fotograbado es una técnica valiéndose de la tecnología utilizando química y electricidad, lo que hace de una especialidad innovadora y atractiva. Se logra representar en la plancha de plata dibujos, ya sea hechos a mano o computarizados, que embellecen aún más el trabajo. Estas técnicas la empresa las terceriza en su mayoría porque las piezas son las más comerciales. Impresión 3D es una empresa dedicada a insertar la tecnología en la industria de la Joyería, permitiendo a sus clientes mejorar la calidad, innovación y satisfacción de los clientes aumentando su prestigio. Este tipo de tecnología permite hacer joyas en alto relieve utilizando planchas gigantes de acero donde se vierte la plata en planchas con diversos volúmenes, y con cuños simétricos se realiza el planchado, en cada plancha pueden salir hasta 50 piezas, todas iguales. Para poder obtener un buen trabajo, depende mucho del cuño que se ha diseñado, un solo defecto en el mismo es replicado por la cantidad de piezas que se producen. Esta empresa solo vende por medios electrónicos y redes sociales, ya que la técnica utilizada garantiza la calidad del mismo, hallándose la oportunidad: "O6. Potencial de las redes sociales para comercializar productos" 
La llegada de la impresión en 3D en el Perú es otro adelanto en una revolución tecnológica que comenzó hace aproximadamente una década, cuando aparecieron los primeros programas CAD específicos para joyería. Actualmente esta tecnología ha ido mejorando y aunque su precio es elevado, los técnicos que las manejan, tiene precios especiales con la empresa debido a los continuos contratos que se lleva con ellos. Incluso han logrado realizar diseños bastante elaborados como diseños étnicos, logrando su fácil exportación, hallando la oportunidad: "O7. Posicionamiento de los diseños étnicos peruanos a nivel mundial" pues en el mundo global tecnológico se pueden hallar tendencias de las modas y el Perú ya manifiesta gusto por productos peruanos o diseños étnicos en las joyas.

La tecnología no solo beneficia en la producción de piezas, sino en la venta de las mismas, puesto que hoy en día el boom del comercio electrónico ya marca tendencia. Los mismos joyeros utilizan incluso las redes sociales para poder generar ventas o mostrar catálogos virtuales, por ello se encuentra dos amenazas “A8. Existencia de empresas virtuales" pues en esta variable de innovación desarrollo precisa las redes sociales y fanpages, herramientas muy utilizadas por las personas que venden solo por internet. Y “A9. Piratería de diseños”, al publicar los diseños propios de las empresas o artesanos es fácil poder copiarlos, al ser fácil de ubicarlos con solo hacer búsquedas selectivas.

\subsubsection{Análisis ecológico.}

El presente análisis se basó en la variable contaminación, siendo la plata la materia prima de las joyas que trabaja la empresa Incas Jewelry S.A.C. Es por eso que se comentará sobre el comportamiento de la extracción de la plata. Asimismo, otras variables son la seguridad e higiene laboral. La razón de colocarlas en el análisis ecológico es debido a la seguridad de las personas que en una joyería trabajan y que deben utilizar en lo posible productos no tan tóxicos y nocivos en la producción de joyas.

- Contaminación: No es nuevo decir que la minería daña el medio ambiente por lo tanto afecta la producción de joyas y puede tener un gran impacto en los trabajadores. La minería de oro, plata, diamantes contaminan el agua, su producción emite gases de efecto invernadero y erosiona el suelo. La Ley General del Ambiente $\mathrm{N}^{\circ} 28611$, señala “Toda persona tiene el derecho irrenunciable a vivir en un ambiente saludable, equilibrado y adecuado para el pleno desarrollo de la vida, y el deber de contribuir a una efectiva gestión ambiental y de proteger el 
ambiente, así como sus componentes" Ambiente (2015). Indicar que la extracción de la plata respeta al medio ambiente seria justificar lo que mundialmente se sabe y es que precisamente la minería es una de las industrias de mayor contaminación ambiental desde su extracción como mineral hasta la entrega de la materia prima al artesano, en el camino se contamina el agua, aire, quizá y sin temor a asegurar que hasta los derechos humanos son suprimidos de alguna manera por las mineras informales.

- Seguridad e Higiene Laboral: Utilizar equipos de seguridad logra disminuir o evitar o un accidente y en el peor escenario hace que la lesión no sea tan grave. De la misma manera se regula el uso de gases permitidos para la producción de joyas. Los elementos metálicos presentes en el ambiente de trabajo de un taller de joyería en forma de polvo, humo o aerosoles son: (a) Aluminio, bajo la forma de dióxido de aluminio (Al2O3). Forma parte de las pastas de pulido; (b) Cromo (Cr), Níquel (Ni), Paladio (Pd), Cinc $(\mathrm{Zn})$ y Cobre $(\mathrm{Cu})$. Forman parte de las aleaciones de piezas de bisutería o de joyería; (c) Cobre $(\mathrm{Cu})$. Forma parte de los hilos de soldadura de plata; (d) Oro (Au), Platino (Pt) y Plata (Ag). Son los metales base de las aleaciones en alta joyería. Todos ellos cuentan con valores límite para controlar su presencia en los ambientes de trabajo. Ya en 1993, la Nueva Constitución Política del Perú. En los artículos 1, 2 (inciso 1), 7, 9 al 12, 22, 23, 58 y 59 se hace referencia a la seguridad y la salud en el trabajo. Por lo tanto, es importante respetarla

\subsection{Impacto en Clientes / Proveedores de cada una de las Variables del Entorno}

En 2013, David mencionó las variables sociales, culturales, demográficas y ambientales que todas las empresas deben tener y que de alguna manera dificulta el crecimiento económico. Para ello se estudiarán las variables de impacto en los clientes, los cuales serán evaluados a profundidad (p. 67).

Complementando a lo que el autor indicó las variables que se nombraron en la relación entre la organización y las fuerzas externas clave. Se procede a analizar el impacto en los clientes, utilizando las variables que afectan a Incas Jewelry S.A.C (ver Tabla 6). Se procede a analizar el impacto en los proveedores, utilizando las variables que afectan a Incas Jewelry S.A.C (ver Tabla 7) y con datos entregados por Gremio de Artesanos del Perú (ver Apéndice B1) 
Tabla 6

Variables Externas y su Impacto en Clientes

\begin{tabular}{|c|c|}
\hline Variables & Impacto en Clientes \\
\hline \multicolumn{2}{|l|}{ Político } \\
\hline Gobernabilidad & $\begin{array}{l}\text { Cuanta mayor estabilidad institucional encuentre el ciudadano en el país, el } \\
\text { consumidor tendrá confianza en adquirir bienes secundarios. }\end{array}$ \\
\hline \multicolumn{2}{|r|}{ e } \\
\hline PBI & $\begin{array}{l}\text { Cuando el precio de la materia prima (plata) se incrementa, los costos de } \\
\text { producción encarecen los precios, por lo tanto, se incrementa el precio de venta. } \\
\text { La demanda de los mercados europeos y asiáticos impactará en que existan }\end{array}$ \\
\hline Factores de importaciones & mayores empresas con posibilidad de exportar. \\
\hline y exportaciones & Los clientes extranjeros que visitan joyerías en el Perú están dispuestos a pagar \\
\hline Patrones de consumo & sumas considerables por este bien. \\
\hline Mercado comercial & $\begin{array}{l}\text { Clientes (personas naturales) que deseen adquirir una cantidad grande de joyas } \\
\text { podrían recurrir a los mayoristas. }\end{array}$ \\
\hline Inflación & $\begin{array}{l}\text { El costo de vida de un país permite o restringe que una persona gaste en } \\
\text { productos de belleza. }\end{array}$ \\
\hline & $\begin{array}{l}\text { La formalidad y cumplimiento de impuestos de una empresa mejora su imagen } \\
\text { ante el consumidor. }\end{array}$ \\
\hline Impuestos & Cuando más se amplían las joyerías mayor cantidad de artesanos deberá \\
\hline Empleo & contratar para poder atender a los clientes. \\
\hline \multicolumn{2}{|r|}{ 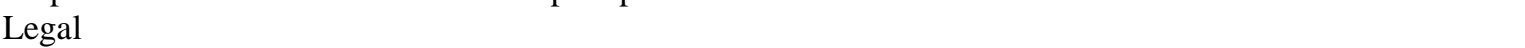 } \\
\hline Legislación & $\begin{array}{l}\text { El que una empresa esté constituida y entrega boletas de venta garantiza al } \\
\text { consumidor sobre el producto que compra. }\end{array}$ \\
\hline Certificación & $\begin{array}{l}\text { No existe mejor garantía de un producto que la certificación mostrada por la } \\
\text { tienda y así el cliente sienta confianza por la compra. }\end{array}$ \\
\hline \multicolumn{2}{|r|}{ ( } \\
\hline Estilo de vida & $\begin{array}{l}\text { En los currículos universitarios del país se le da poco valor a lo cultural, } \\
\text { antropológico, a las raíces de las poblaciones incas de artesanía o joyería que } \\
\text { utilicen piedras nativas y esto no ayuda a que el consumidor adopte comprar en } \\
\text { joyerías de diseño peruano. }\end{array}$ \\
\hline \multicolumn{2}{|r|}{ P } \\
\hline Innovación y desarrollo & $\begin{array}{l}\text { La gran industria que cubre todos los campos en joyería ha impactado } \\
\text { fuertemente con productos en laboratorios de las gemas y piedras preciosas a } \\
\text { muy bajo costo con las que no se puede competir de las piedras naturales. Esta } \\
\text { disminución el costo de la joya favorece al cliente. } \\
\text { Los clientes pueden comprar productos de manera virtual utilizando sus redes } \\
\text { sociales o páginas de comercio electrónico. }\end{array}$ \\
\hline \multicolumn{2}{|r|}{ 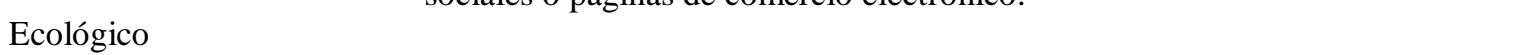 } \\
\hline Contaminación & $\begin{array}{l}\text { El mercado cada vez es más exigente en el desarrollo sostenible y por tanto } \\
\text { existe productos certificados ecológicamente y de precio justo. }\end{array}$ \\
\hline $\begin{array}{l}\text { Seguridad e higiene } \\
\text { laboral }\end{array}$ & $\begin{array}{l}\text { El cliente cuando visita los talleres de producción requiere las herramientas se } \\
\text { seguridad necesarias básicas. }\end{array}$ \\
\hline
\end{tabular}

Nota. Adaptado de Conceptos de Administración Estratégica (p. 66), por F. David, 2013, México,

D.F., México: Prentice Hall. Copyrigth 2013 por Pearson Education.

\subsection{Efecto en la Empresa de cada una de las Variables del Entorno}

En el 2013, David señaló “Los cambios ocurridos en las fuerzas externas se traducen en modificaciones en la demanda del consumidor, tanto en lo que concierne a productos y servicios industriales como de consumo. Las fuerzas externas afectan el tipo de productos que se desarrollan, la naturaleza de las estrategias de posicionamiento y segmentación del mercado, 
el tipo de servicios que se ofrecen y las decisiones de las empresas en materia de adquisiciones y ventas. Además, tienen un impacto directo en proveedores y distribuidores." (p.63). Por ello se procede a analizar el efecto en la empresa, utilizando las variables que afectan a Incas Jewelry S.A.C, para este punto se ayudó de respuestas del Gerente General de la empresa (ver Apéndice A1 y Tabla 8).

Tabla 7

Variables Externas y su Impacto en Proveedores.

\begin{tabular}{|c|c|}
\hline Variables & Impacto en Proveedores \\
\hline \multicolumn{2}{|l|}{ Político } \\
\hline Gobernabilidad & $\begin{array}{l}\text { La paralización económica del país producto del escándalo de Odebrecht hizo que ciertas } \\
\text { empresas vinculadas y que tercerizaban materia prima paren su producción paralizando } \\
\text { la economía del país }\end{array}$ \\
\hline \multicolumn{2}{|r|}{ 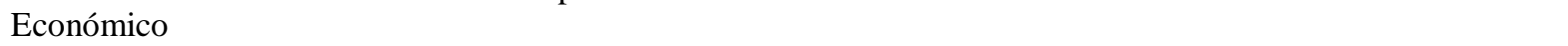 } \\
\hline PBI & $\begin{array}{l}\text { Cada proveedor maneja sus precios, producto de la informalidad, pues no entregan } \\
\text { boletas ni comprobantes de pago afectando la caja de la empresa. }\end{array}$ \\
\hline Factores de & $\begin{array}{l}\text { Las empresas mayoristas de la industria joyera son proveedores de joyerías extranjeras y } \\
\text { en consecuencia si existe un alta demanda los proveedores. }\end{array}$ \\
\hline $\begin{array}{l}\text { importaciones y } \\
\text { exportaciones }\end{array}$ & $\begin{array}{l}\text { Los diferentes cambios en el comportamiento de compra del consumidor impactarán } \\
\text { directamente en la variedad de pedidos a los proveedores. }\end{array}$ \\
\hline $\begin{array}{l}\text { Patrones de } \\
\text { consumo }\end{array}$ & $\begin{array}{l}\text { El dinamismo que tenga el mercado joyero determinará el aumento o la reducción de los } \\
\text { mayoristas y proveedores. }\end{array}$ \\
\hline $\begin{array}{l}\text { Mercado comercial } \\
\text { Inflación }\end{array}$ & $\begin{array}{l}\text { Cuando hay inflación los proveedores buscan recuperar los costos de producción por lo } \\
\text { tanto el precio ofrecido a las joyerías se incrementa, siendo las beneficiarias las empresas } \\
\text { grandes o marcas reconocidas. }\end{array}$ \\
\hline & $\begin{array}{l}\text { A mayor cantidad de proveedores formales se incrementa el costo de los productos, } \\
\text { debido a los impuestos y por el contrario los informales al no pagar impuesto bajan sus }\end{array}$ \\
\hline Impuestos & precios proporcionando una competencia desleal. \\
\hline Empleo & $\begin{array}{l}\text { Con el cadenas empresas joyeras, los proveedores artesanos tendrán que contratar más } \\
\text { personas de oficio para ayudarlos }\end{array}$ \\
\hline \multicolumn{2}{|r|}{ 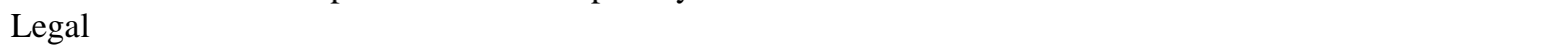 } \\
\hline Legislación & $\begin{array}{l}\text { La mayoría de los proveedores son informales motivo por el cual no hay leyes que } \\
\text { amparen a la empresa formal cuando un delito es cometido por el informal (ver Apéndice } \\
\text { A3) }\end{array}$ \\
\hline Certificación & $\begin{array}{l}\text { El proveedor de plata cuenta con una certificación de la venta de plata lo que encarece el } \\
\text { precio de la misma, pero el proveedor informal la vende sin restricción alguna originado } \\
\text { que los precios de quien las compra son menores, pero con el riesgo de que el producto } \\
\text { sea de mala calidad. }\end{array}$ \\
\hline \multicolumn{2}{|r|}{ ( } \\
\hline Estilo de vida & $\begin{array}{l}\text { La mayoría de los artesanos son nativos y dominan bien el arte de su cultura por lo tanto } \\
\text { el trabajo que ellos realizan y entregan son del gusto del consumidor. }\end{array}$ \\
\hline \multicolumn{2}{|r|}{ 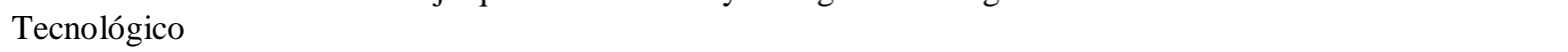 } \\
\hline $\begin{array}{l}\text { Innovación y } \\
\text { desarrollo }\end{array}$ & $\begin{array}{l}\text { A pesar de que la mayoría de los proveedores tiene una producción artesanal, ya se están } \\
\text { sumando trabajos utilizando tecnología y ellos se capacitan y adquieren equipos } \\
\text { sofisticados y aumenta el valor de sus piezas o trabajos realizados. }\end{array}$ \\
\hline \multicolumn{2}{|r|}{ 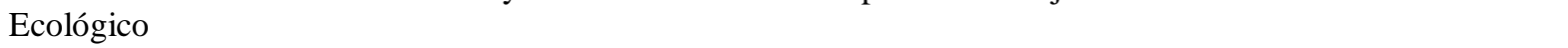 } \\
\hline Contaminación & $\begin{array}{l}\text { Las empresas informales al extraer su materia prima, cual fuera su insumo no presentan } \\
\text { garantía de que sus talleres no tengan exceso de gases tóxicos. } \\
\text { Las empresas no siempre cumplen con las medidas de seguridad mínimas que piden, ni } \\
\text { en tienda ni taller, cuando llega la revisión técnica, usualmente falsean los datos. }\end{array}$ \\
\hline
\end{tabular}

Nota. Adaptado de Conceptos de Administración Estratégica (p. 66), por F. David, 2013, México, D.F., México: Prentice Hall. Copyrigth 2013 por Pearson Education. 
Tabla 8

Variables Externas y su Efecto en la Empresa.

Variables

Efecto en la Empresa

Político

Gobernabilidad

La gobernabilidad y estabilidad de un gobierno impacta en la decisión en inversiones por parte de las empresas.

Las noticias de corrupción de autoridades públicas contraen las diferentes campañas de marketing.

Pero también los tratados como el TLC trae muchos inversionistas al Perú, también ingresan extranjeros y compran productos peruanos pues les atrae la plata peruana también y la compran debido a que tienen un mayor poder adquisitivo

Económico

PBI

Los niveles de demanda externa de joyas de plata impactan en el incremento de los volúmenes de exportación por parte de las empresas, en este caso se incrementa el precio de la plata según demanda

Factores de import. y Mientras mayor número de importadores extranjeros existan la posibilidad de que aumenten las exportaciones exportaciones son mayores.

Patrones de consumo El comportamiento de compra del consumidor se verá reflejado en el portafolio de productos de las empresas y en sus ingresos.

Mercado comercial El mercado de la industria joyera tiene muy pocos márgenes de ganancia lo que hace que las empresas deban manejar diversas estrategias para captar a los clientes.

Inflación $\quad$ Dificultad para mantener los niveles de venta porque el consumidor reduce su poder adquisitivo. Dejando el poder a las grandes empresas o marcas reconocidas con quienes es difícil competir. Incluso les da poder para generar promociones.

Impuestos Como es una obligación el pagar impuestos se incrementa los costos de producción. Es en este punto en que las empresas informales sacan mayor provecho.

Uno de los beneficios de ser empresa formal es poder participar en ferias locales o internacionales pues es un requisito en muchas ser una empresa constituida.

Empleo Sin importar los volúmenes de venta, se debe cumplir siempre con la planilla. Los artesanos de la tienda al ser empleados por destajo tientan a copiar los diseños y venderlos como suyos. Esta variable también se manifiesta cuando se entrega las joyas a otros establecimientos o a personas (amas de casa) con la intención de vender joyas en consignación, generando en ellas oportunidades de generar dinero en sus familias.

Legal

Legislación

Una adecuada legislación que proteja el trabajo y producción de las empresas formales versus las informales ayudará a que la formalidad crezca en el mercado nacional. La tienda se encuentra en Miraflores, lugar exclusivo, pero las competencias en su mayoría no son formales o no entregan boletas.

Certificación La obtención de certificados de calidad de elaboración de joyas impactará en la mejor imagen de las empresas frente a sus clientes.

La empresa cuenta con proveedores formales con quienes ha formado alianzas estratégicas, con la intención de mantener una buena calidad de los productos. Según entrevista en profundidad a personal interno (ver Apéndice A)

Cultural

Estilo de vida

Una adecuada preparación y conocimiento por parte de los vendedores de las empresas ayudará no solo a incrementar sus ventas a los clientes extranjeros sino también a difundir nuestra cultura milenaria sobre el trabajo de joyería peruana.

La tienda debe estar preparada para los diferentes tipos de preferencias, algunos desean productos más baratos como bisutería o se van al otro extremo prefiriendo oro o diamantes. La tendencia de las personas por lucir joyas de plata va en aumento lo que hace que la empresa genere nuevas colecciones para atraer al cliente consumidor.

Tecnológico Innovación y desarrollo

El uso de herramientas y máquinas de producción de joyas mejora la calidad del producto final versus lo que la artesanía informal e ilegal produce. Por otro lado está creciendo las empresas virtuales, los clientes suelen utilizar esta herramienta, como medio de venta.

Ecológico

Contaminación no dañen el medio ambiente.
Nota. Adaptado de Conceptos de Administración Estratégica (p. 66), por F. David, 2013,
México, D.F., México: Prentice Hall. Copyrigth 2013 por Pearson Education. En los talleres es necesario tener los requerimientos mínimos necesarios en cuanto a gases y que 


\subsection{Oportunidades y Amenazas}

En el 2013, David señaló “Las oportunidades y amenazas externas se refieren a las tendencias y acontecimientos económicos, sociales, culturales, demográficos, ambientales, políticos, legales, gubernamentales, tecnológicos y competitivos que podrían beneficiar o perjudicar de modo significativo a una organización en el futuro". (p.64). Para ello se nombrará las oportunidades y amenazas que son los factores externos determinantes del éxito de la empresa (ver Tabla 9). Para poder determinar ciertas variables se analizaron las respuestas de un experto en la industria de la platería (ver Apéndice A5).

Tabla 9

Oportunidades y Amenazas

\section{Oportunidades}

O1. Existencia de TLC con países con alto potencial de compradores y proveedores

$\mathrm{O} 2$. Alta demanda de compradores de joyas de plata

O3. Existencia de importadores de Europa y Asia

O4. Alto poder adquisitivo de clientes extranjeros

O5. Existencia de ferias

O6. Potencial de las redes sociales para comercializar productos

O7. Posicionamiento de los diseños étnicos peruanos a nivel mundial

\section{Amenazas}

A1. Presencia de mayoristas

A2. Existencia de productos sustitutos

A3. Economía de escala de las grandes tiendas

A4. Alza de precio de los insumos

A5. Limitado apoyo de la cámara de comercio

A6. Alta informalidad en el mercado

A7. Presencia de grandes marcas

A8. Existencia de empresas virtuales

A9. Piratería de diseños

Nota. Adaptado de Conceptos de Administración Estratégica (p. 66), por F. David, 2013, México, D.F., México: Prentice Hall. Copyrigth 2013 por Pearson Education.

\subsection{Matriz de Evaluación de los Factores Externos EFE}

En el 2013, David señaló “La matriz de evaluación de factores externos (EFE) permite que los estrategas resuman y evalúen información económica, social, cultural, demográfica, ambiental, política, gubernamental, legal, tecnológica y competitiva.” (p.80)

Asimismo, David señaló que seleccionar entre 15 y 20 factores es lo ideal entre oportunidades y amenazas. Los autores presentaron 16. La determinación de las ponderaciones más apropiadas puede lograrse comparando a los competidores exitosos con los no exitosos, o analizando el factor y llegando a un consenso grupal. La suma de todas las ponderaciones asignadas a los factores debe ser igual a 1.0. Para este caso se trabajó con las empresas M\&F y Spondylus que son las competencia débil y fuerte. Y fueron validadas por un experto de la industria joyera (ver Apéndice A5) 
En la Tabla 10 se muestra la Matriz EFE, que son los factores externos de la empresa Incas Jewelry, determinados por la empresa, las mismas que fueron tomadas de las entrevistas en profundidad a expertos de la industria. David (2013) señaló que sin importar el número de oportunidades o amenazas clave incluidas en una matriz EFE, la puntuación ponderada total más alta posible para una organización es de 4.0, y la más baja posible es de 1.0. La puntuación ponderada total promedio es de 2.5. La ponderación 2.35 indica que Incas Jewelry no está aprovechando las oportunidades existentes ni estar neutralizando las amenazas que puede tener efectos adversos.

Tabla 10

Matriz EFE

\begin{tabular}{|c|c|c|c|}
\hline Oportunidades & Ponderación & Calificación & Total \\
\hline $\begin{array}{l}\text { O1. Existencia de TLC con países con alto } \\
\text { potencial de compradores y proveedores }\end{array}$ & 0.08 & 1 & 0.08 \\
\hline $\begin{array}{l}\text { O2. Alta demanda de compradores de joyas } \\
\text { de plata }\end{array}$ & 0.08 & 3 & 0.24 \\
\hline $\begin{array}{l}\text { O3. Existencia de importadores de Europa y } \\
\text { Asia }\end{array}$ & 0.03 & 2 & 0.06 \\
\hline $\begin{array}{l}\text { O4. Alto poder adquisitivo de clientes } \\
\text { extranjeros }\end{array}$ & 0.03 & 2 & 0.06 \\
\hline O5. Existencia de ferias & 0.03 & 2 & 0.06 \\
\hline $\begin{array}{l}\text { O6. Potencial de las redes sociales para } \\
\text { comercializar productos }\end{array}$ & 0.03 & 1 & 0.03 \\
\hline $\begin{array}{l}\text { O7. Posicionamiento de los diseños étnicos } \\
\text { peruanos a nivel mundial } \\
\text { Amenazas }\end{array}$ & 0.06 & 2 & 0.12 \\
\hline A1. Presencia de mayoristas & 0.08 & 3 & 0.24 \\
\hline A2. Existencia de productos sustitutos & 0.06 & 1 & 0.06 \\
\hline $\begin{array}{l}\text { A3. Economía de escala de las grandes } \\
\text { tiendas }\end{array}$ & 0.08 & 3 & 0.24 \\
\hline A4. Alza de precio de los insumos & 0.06 & 3 & 0.18 \\
\hline $\begin{array}{l}\text { A5. Limitado apoyo de la cámara de } \\
\text { comercio }\end{array}$ & 0.06 & 3 & 0.18 \\
\hline A6. Alta informalidad en el sector & 0.10 & 3 & 0.30 \\
\hline A7. Presencia de grandes marcas & 0.08 & 2 & 0.16 \\
\hline A8. Existencia de empresas virtuales & 0.06 & 3 & 0.18 \\
\hline A9. Piratería de diseños & 0.08 & 2 & 0.16 \\
\hline
\end{tabular}

Nota. 1: La respuesta es deficiente; 2: La respuesta es promedio; 3 Respuesta por encima del promedio; 4: Respuesta superior; para indicar con cuánta eficacia la empresa responde a dicho factor.Y el Total es la multiplicación de ponderación por calificación. Adaptado de Conceptos de Administración Estratégica (p. 81), por F. David, 2013, México, D.F., México: Prentice Hall. Copyrigth 2013 por Pearson Education. 


\section{Capítulo V: Análisis de la Industria}

Para este capítulo se realizaron entrevistas en profundidad a expertos en la industria de la joyería, como: Mincetur, Joyas M\&F, Spondylus y Gremio de Artesanos del Perú. Con estos datos se describió el mercado y la industria, luego las cinco fuerzas competitivas de la industria y en ellas se establecieron las oportunidades y amenazas de la empresa.

\subsection{Oportunidades}

En el 2013, David señaló “Los mercados pueden estar determinados por áreas geográficas o por segmentos de producto"..." Los investigadores utilizan términos como uniformidad del mercado y similitud de recursos para analizar la rivalidad entre competidores. La uniformidad del mercado puede definirse como el número y la importancia de los mercados en los que una empresa compite con sus rivales". (p.75)

En 2017, Adex indicó que el mercado de la joyería ha ido creciendo notablemente, incrementándose el volumen de exportaciones. Este informe también señala que Perú es el segundo productor de plata, siendo el primero México. En 2016, Pérez señaló que la industria de la joyería en el exterior creció en el 2016, pues lo envíos de joyería y orfebrería peruana alcanzaron los US\$ 49.5 millones, 8\% superior a lo ocurrido en el 2015 en la que sumó US\$ 45.9 millones.

Complementando a David el mercado se determina por la zona geográfica, afirmando que Perú aprovecha ventajosamente eso ya que es un país rico en recursos naturales, específicamente oro y plata en diversas áreas de nuestra geografía. Es precisamente la plata el metal sobre el cual basamos el presente trabajo ya que es el insumo o materia prima principal de las joyas que la empresa produce y comercializa.

Se espera que el alza en los precios del oro y la plata puedan cambiar las preferencias de los consumidores, como también el impacto de su comportamiento de la demanda. Y La sofisticación creciente de los consumidores, la disminución de la demanda de joyas impulsado por la inversión y la competencia de otros bienes de lujo también es probable que impacten sobre el comportamiento de la demanda de gemas y joyería. (Promperu, 2018)

\subsection{Descripción las Cinco Fuerzas Competitivas de la Industria}

Como Porter (2012) lo establece Existen cinco fuerzas que ayudan a desarrollar una serie de ventajas que ayudan a cualquier empresa ser un negocio competitivo con la finalidad de maximizar los recursos y superar a la competencia. Asimismo, se menciona en el libro lo 
siguiente: "Si no se cuenta con un plan perfectamente elaborado, no se puede sobrevivir en el mundo de los negocios de ninguna forma”. (p.75)

En 1998, Majluf analizó las cinco fuerzas con fin de detectar el atractivo de la industria desde las perspectivas de rentabilidad a largo plazo, con sus principales participantes: Competidores, compradores, proveedores, sustitutos y nuevos participantes. Analizaremos las cinco fuerzas y las variables que se ajustan a la empresa cuyo rubro principal es la joyería de plata. Es importante indicar que solo se han considerado aquellas variables que impactan a la empresa. Para la descripción de las cinco fuerzas se utilizaron las entrevistas en profundidad a expertos en la industria de la joyería y a cinco personas del Gremio de Artesanos se les mostró las tablas con las cinco fuerzas y estas fueron llenadas por ellos (ver Apéndice B1) y se tomó información de la Gerente de Tienda Incas Jewelry (ver Apéndice A3).

\subsubsection{Sustitutos - Desarrollo potencial de productos sustitutos.}

Como se aprecia existe un alto desarrollo potencial de productos sustitutos. Muchas personas naturales están creando pymes con productos con características similares a las de Incas Jewelry S.A.C. lo que reafirma el permanentemente ingreso de nuevos competidores. Según lo indicado en las entrevistas a otras joyerías, todas coinciden en que los clientes siempre tienen un poder de negociación normal para el caso de las joyerías, tienen a entender que el precio es elevado debido a la calidad del producto, por lo tanto de la misma manera se manejan a los proveedores.

Perú tiene oportunidad en la industria de la joyería, cada vez toma una mejor posición en el mercado, incluso en el extranjero, así como lo señala uno de los expertos Alejandro Pino en una pequeña entrevista vía telefónica. Actualmente Perú tiene mucha competencia en la joyería en cuanto a los productos sustitutos que en su mayoría son traídos de China y son de preferencia de cierto público que los prefiere no solo por el precio, más si por el diseño distinto, fuera de lo común, sin importarles en muchos casos la calidad del mismo. Siendo los productos sustitutos joyas de oro, diamante, fantasía fina, cobre bañados en plata y rodio.

Las tablas adjuntas muestran el promedio de las fichas llenadas por cinco integrantes de joyeros y artesanos del Gremio de Artesanos de Lima, inscritos en Promperu. Asimismo, se analizaron las respuestas realizadas a los clientes que frecuentan la tienda y que por lo menos hayan realizado tres compras en el año (ver Apéndice B2). Se procede a describir las variables de esta fuerza:

- Tendencia del comprador a sustituir. Cuando el poder adquisitivo del cliente es reducido, este tiende a buscar una alternativa de producto con un valor menor 
dejando sin efecto la compra de la joya de plata o en su defecto cuando considera que la joya de plata no es de su agrado completamente adquiere una joya de mayor valor como de oro, diamantes, perlas, etc. Un tema que está preocupando a la industria joyera es el ingreso de joyas de Asia y que por su bajo precio es de elección de algunos clientes, tomando de esta manera la amenaza "A2. Existencia de productos sustitutos"

- Precios relativos de los productos sustitutos: La bisutería tiene un precio menor debido a que sus costos de producción también son bajos. Por otro lado, el oro es un producto sustituto caro y que algunos clientes potenciales lo solicitan cuando privilegian la calidad del mismo. El ingreso de joyas chinas también está siendo bien vistas por el consumidor peruano, pues maneja precios bastante bajos en comparación a la joya de plata peruana. Por ello se determina la oportunidad "O 3 . Existencia de importadores de Europa y Asia"

- Coste o facilidad de cambio del comprador: El cliente local o extranjero tiene facilidad para cambiar de producto, puede ir con intención de compra de una joya de plata y dependiendo del precio del mismo, cambiar su opción por una joya más cara como es el oro o diamante (ver Apéndice A3). También ocurre en el caso contrario pues elige comprar una joya de cobre bañada en plata o rodio.

- Nivel percibido de diferenciación de producto o servicio: Esto tiene que ver con la calidad de atención de cómo percibe el cliente al vendedor. Este último actor es importante en lo que se desea vender ya que, si vendes artículos como plata, el vendedor debe ser profesional con sentido de conocimiento el producto $y$ habilidades de venta.

- Disponibilidad de sustitutos cercanos: Todas las joyerías venden productos similares a las de plata porque son las que atraen más al cliente por el precio. Una variable importante en la industria de la joyería es la fabricación de plata trucha, que es una joya de otro material bañado en plata, que tienen mucha salida precisamente por sus precios bajos. Otro sustituto lo representan los accesorios o joyas chinas ofrecidas como plata, pues incluso tiene sello, pero no lo son y por sus diseños distintos a los del Perú, tienen cierta demanda en el mercado peruano.

- Suficientes proveedores: Existencia de oferta de productos desde lo más caro hasta lo extremadamente barato que tiene relación con la calidad de la joya. El cliente finamente tiene muchas opciones de compra para llevarse un producto. 


\subsubsection{Potenciales - Entrada potencial de nuevos competidores.}

Hay muchos factores que hacen que sea difícil entrar en la industria de las joyas. Algunos de los factores importantes son la imagen de la marca y la lealtad, gastos de publicidad, distribución minorista y mayorista. Cuando un nuevo diseño sale de alguna joyería y los clientes empiezan a preguntar por este, Incas Jewelry empieza a diseñar joyas con características muy similares porque sabe que marcará alguna tendencia en compra, y como ya no es igual, logra gustar. Se procede a describir las variables de esta fuerza:

- Existencia de barreras a la entrada: Para una empresa formalmente constituida no representa una barrera ingresar en el sector de la joyería, pues los documentos que piden no son difíciles de tramitar, teniendo en cuenta que la mayoría de empresas que ingresan a esta industria llevaron años de manera informal y al conocer el mercado y querer mejores oportunidades es precisamente que formalizan.

- Valor de la marca: Debido a la economía de gran escala las empresas que tienen a posicionar mejor sus productos son las empresas ya conocidas en el mercado, por ello se encuentra la amenaza "A3. Economía de escala de las grandes tiendas"

- Requerimiento de capital: Poner en marcha una joyería requiere de un buen capital que permita mantener un buen stock de joyas, pago a los empleados, joyeros y artesanos. Incluso para participar de los eventos patrocinados por la Cámara de Comercio se necesita capital, porque los impuestos que se paga por los productos vendidos en los eventos son altos, por ello se halla la amenaza "A5. Limitado apoyo de la cámara de comercio"

- Diferenciación de producto: En la industria joyera la diferenciación del producto radica en los diseños propios que cada artesano genera y que por ende genera identidad con el cliente. La intención es hacer una pieza que no sea una réplica pero sí que tenga un valor agregado que la haga una pieza diferente, esto en acuerdo con el cliente.

- Costos de cambio: Las grandes empresas manejan precios altos en las ventas de sus joyas y cuando un cliente visita una tienda pymes espera encontrar un precio inferior a la mitad de lo que ofrece la tienda grande siendo complicado bajar los precios porque producir una joya a la medida del gusto del cliente tiene un precio de producción alto, porque a veces tiene que ser trabajado a mano.

- Acceso a la distribución: Ingresar como empresa nueva en la distribución de productos como joyas no es una tarea fácil, pues existe cierta desconfianza en referir las mejores marcas o diseños. Por otro lado, la mayoría de los joyeros y 
artesanos son familia y muchas veces ellos mismos son distribuidores y si alguno de ellos apertura una tienda, la distribución para ellos es más fácil (ver Apéndice A4).

- Ventajas de la curva de aprendizaje: La industria joyera siempre está en constante aprendizaje, los gustos de los clientes cambian constantemente y en la actualidad esto se ve reflejado en las redes sociales, muchas empresas realizan sus ventas solo por internet, algo que al inicio le costó comprender a las grandes joyerías. Es por ello que se encuentra la amenaza "A8. Existencia de empresas virtuales”, pues la mayoría que vende por internet tiene más posibilidad de vender sus productos.

- Políticas gubernamentales. Con el tiempo la empresa ha sabido mantenerse en el mercado utilizando las diferentes herramientas que el gobierno propone para las pymes (Ver Apéndice A1).

\subsubsection{Clientes - Poder de negociación de los consumidores.}

Los clientes o consumidores en esta industria tienen poder de negociación, ya que son la fuente principal de los ingresos y cuota de mercado en industria de joyas. Según los expertos consultados indican que son los clientes quienes demuestran notablemente el poder de compra y cómo algunos clientes especiales pagan precios diferentes en función de su poder de negociación. Por ello, se procede a describir las variables de esta fuerza:

- El producto comprado no representa parte importante de sus compras: Los clientes buscan reducir costos en artículos no básicos, como son joyas. Sin embargo, las personas en su mayoría mujeres gustan lucir artículos de plata en todo momento. Algo que impide una compra es que por temporadas las joyas suben debido al alza del valor de la plata.

- Volumen del comprador: El cliente consumidor puede negociar el precio de su producto si es que compra joyas en cantidades grandes, ya sean realizadas en una misma compra o por ser cliente frecuente. Obteniendo la oportunidad "O2. Alta demanda de compradores locales de joyas"

- Disponibilidad de información para el comprador: Los clientes locales y extranjeros hacen uso de las redes sociales para buscar mejores precios de piezas de joyas de plata, estas empresas virtuales muestran colecciones de sus productos. Incluso en los hoteles proporcionan información de los lugares de compras de piezas de plata debido a sus gustos y preferencias por joyas de plata peruana y su posición económica les permite pagar por ellas y sus diseños exclusivos es que se encuentran dos oportunidades: "O4. Alto poder adquisitivo de clientes 
extranjeros” y “O7. Posicionamiento de los diseños étnicos peruanos a nivel mundial"

- Grado de dependencia de los canales de distribución: Los clientes prefieren que sus productos sean enviados a sus oficinas, casas o donde se encuentren y para ello se utiliza una red de canales de distribución como Olva Courier, DHL, Cabify, Glovo entre otros.

- Costes o facilidades del cliente de cambiar de empresa: El cliente siempre tiene la opción de consultar precios en diferentes establecimientos y puede comprar finalmente en otro lugar a pesar de que averiguó todo sobre el producto en la primera tienda.

- Existencia de productos sustitutos: Siempre habrá otro producto que pueda reemplazar a lo que inicialmente el cliente desea comprar ya sea por calidad o por precio que suele ser la razón principal por la que el cliente deja de comprar la joya de plata y compra otro.

- Sensibilidad del comprador al precio: Por naturaleza el consumidor es quien oferta los productos dando los precios que le conviene, es en este caso que busca diseños únicos que sabe ya fueron copiados y por ende son más baratos que los ofrecidos por otras joyerías. En este punto se encuentra la amenaza: “A9. Piratería de diseños"

\subsubsection{Proveedores - Poder de negociación de los proveedores.}

Es difícil que los proveedores mantengan un status de exclusividad, pues el producto que ofrecen a la tienda, bien puede ser ofrecido a otra. Una ventaja es que los mismos proveedores son los que te informan de cómo está la situación del mercado de la plata, porque sacan diseños novedosos y su calidad es bien cuidada. Se procede a describir las variables de esta fuerza:

- El producto es diferenciado o tiene altos costos por cambio: Al vender diseños exclusivos involucra precios de producción altos y al ser realizados a mano, cuando piden nuevamente la pieza esta difícilmente queda igual, siempre existe un margen que lo diferencia, ya sea en el tamaño o peso o alguna característica en la misma.

- Presencia de productos sustitutivos: Desde hace buen tiempo, no se podría especificar cuanto, pero existe la plata trucha, denominada así por los artesanos que trabajan cobre bañado en plata, por fuera es una pieza de plata y que no se deteriora con facilidad, al menos que se rompa, incluso esta tiende a negrearse. 
Este tipo de joya es bastante ofrecido por los artesanos a las tiendas y ellos las venden como plata pura. El ingreso de este producto sustituto baratea a quienes venden plata pura. Otro producto sustituto son las joyas chinas que tienen sello de plata, pero son de baja calidad y por ende de menor precio. También se encuentra el oro y el diamante traído de la India, que a pesar de tener precios altos de venta también tienen cierta demanda en el mercado.

- Concentración de los proveedores: La empresa mantiene un buen trato con los proveedores de piedras naturales y algunas piezas de plata, con ellos se tienen alianzas, ellos dejan su material y las tiendan los venden

- Coste de los productos del proveedor en relación con el coste del producto final: Estos costos van directamente relacionados con el tipo de empresas, los proveedores informales venden a precios baratos por lo tanto vender el producto final deja mayor utilidad. Grandes joyerías prefieren las joyas fuera del Perú, pues les pagan más y porque expertos de la industria indican que las minerías, por ello se encuentra la amenaza "A4. Alza de precio de los insumos"

\subsubsection{Competencia en el mismo sector - Rivalidad entre empresas competidoras.}

La existencia de la competencia en la industria joyera es algunos casos refleja el consumo de este producto, para el caso de las joyas de plata, existen muchas empresas dedicadas a este rubro. Se procede a describir las variables de esta fuerza:

- Poder de los competidores: La competencia básicamente controla los precios de salida de productos, el poder del competidor radica en el precio más bajo que puede ofrecer.

- Poder de los proveedores: El proveedor sabe a quién dejar sus piezas, empresa que genera mayor pedido es porque tiene mayor salida de los productos que este deja, por ello se determina la siguiente amenaza: "A2. Presencia de mayoristas"

- Crecimiento industrial: Existe un crecimiento de la industria de la joyería, muchos informales ya están formalizando su situación porque varios desean exportar y para ello es necesario estar constituidos, lo que no impide que tengan productos de mala calidad. Expertos de la industria indican que los TLC deben ser aprovechados por todos porque dan oportunidad a mercado de vender sus productos, es por ello se determina a siguiente oportunidad: “O1. Existencia de TLC con países con alto potencial de compradores y proveedores"

- Amenaza de nuevos competidores: La mayoría de las joyerías tanto pymes como grandes se ubican en galerías o están asociadas por departamentos en los centros 
comerciales por ello se determina la siguiente amenaza: "A1. Presencia de grandes marcas"

- Diversidad de competidores: La competencia en la industria joyera se ha incrementado y este a su vez ha diversificado sus productos puesto que existen empresas que venden muchos artículos similares. Incluso hay pymes que no producen, sino que compran las joyas hechas a artesanos a precios muy bajos y los venden a costos elevados porque tienen una red de contactos muy buena a quienes poder ofrecer, esto se debe a que muchas empresas son informales, es por ello que se determina la siguiente amenaza: "A6. Alta informalidad en el sector"

- Poder de los compradores: Un comprador no satisfecho acude con mayor rapidez a comprar sus productos en la competencia, a veces no le importa la calidad y procedencia de los insumos, solo desea pagar menos. Hoy en día existe la tendencia a comprar por internet es por ello que determina la oportunidad: "O6. Potencial de las redes sociales para comercializar productos “

- Amenaza de productos sustitutivos: Tal cual se indicó en líneas anteriores, la competencia vende plata trucha o plata de baja calidad y muchas de las joyerías las venden con precios inferiores, sin garantía, esta información es real y entregada por la Gerente de Tienda de la empresa Incas Jewelry. Varias de las joyerías de la galería venden joyas chinas lo que hace su precio de venta más bajo.

- Identidad de la marca: Una de las variables importantes según expertos es que las empresas joyeras pretenden hacer de su marca una identidad que les permita reconocimiento y en el Perú, Promperu y Mincetur organizan ferias para que las empresas coloquen sus productos, es por ello que se determina la oportunidad: "O6. Existencia de ferias"

\subsection{Matriz de Atractividad de cada una de las Cinco Fuerzas}

En 1998, Majluf analizó la matriz de atractividad partiendo del concepto de las cinco fuerzas de Porter y señaló: "Debemos comprender los factores fundamentales que determinan sus perspectivas de rentabilidad a largo plazo, dado que este indicador incorpora una medición general del atractivo de la industria”. (p.56). Para realizar esta matriz se realizó entrevista en profundidad al Personal Interno, Gerente de Operaciones de la Empresa; Al Gerente General de la Competencia; Gremio de Artesanos. Se aplicó cuestionarios a clientes de la empresa (ver Apéndice B2) y a empresas que son competencia (ver Apéndice A6 y A7)

En base a conversaciones con el gremio de artesanos y joyeros de Lima inscritos en la Cámara de Comercio de Lima, quienes se reúnen una vez al mes, se les solicitó que indiquen 
cuales de todas las variables sugeridas son pertinentes a esta industria. Es con esas variables con las que se analiza las siguientes tablas. Estas conversaciones no pudieron ser grabadas porque ellos no aceptaron.

Dentro de las consultas que se les dio para la ponderación fueron: a) "Asigne un peso entre 0.0 (no importante) a 1.0 (absolutamente importante) a cada uno de los factores colocadas en las variables"; b) Mida el impacto de estas variables, siendo 1 el impacto más bajo en la industria de la joyería en Lima y 100 el impacto más alto”. Y colocar en la primera línea comportamiento actual de la industria joyera y en la segunda el comportamiento a futuro (ver Apéndice B1). Las ponderaciones e impacto de las tablas adjuntas representan el promedio de los números sacados de las conversaciones con los seis artesanos y joyeros reunidos el 16 de marzo del 2018.

\subsubsection{Sustitutos - Desarrollo potencial de productos sustitutos.}

Se consideró seis variables para la fuerza competitiva "Desarrollo Potencial de Productos Sustitutos (ver Tabla 11). En la encuesta realizada a los clientes principales de Incas Jewelry que un 60\% de ellos le interesa comprar una joya de alta calidad como la plata y solo el $27 \%$ compra bisutería con algunas piezas de plata. También en la tabla se muestran los resultados de los datos analizados extraídos de la entrevista en profundidad realizada el Gremio de Artesanos de Lima, inscritos en Promperu (ver Apéndice B1). Como resultado de este análisis se determinaron las amenazas: "A2. Existencia de productos sustitutos”, ubicadas y detalladas en "Tendencia del comprador a sustituir". Asimismo, se determinó una oportunidad: “A6. Limitado apoyo de la cámara de comercio”, ubicado y detallado en "Precios relativos de los productos sustitutos"

Tabla 11

Matriz de Atractividad de la Fuerza "Desarrollo Potencial de Productos Sustitutos".

\begin{tabular}{|c|c|c|c|c|c|c|c|}
\hline & & 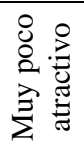 & 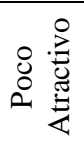 & $\begin{array}{l}\stackrel{0}{0} \\
\text { ¿े } \\
\text { Z }\end{array}$ & 胥 & 怘总 & \\
\hline Tendencia del comprador a sustituir & Alta & & & & & & Alta \\
\hline Precios relativos de los productos sustitutos. & Alta & & & & & & Alta \\
\hline Coste o facilidad de cambio del comprador. & Alta & & & & & & Baja \\
\hline $\begin{array}{l}\text { Nivel percibido de diferenciación de producto o } \\
\text { servicio. }\end{array}$ & Baja & & & & & & Baja \\
\hline Disponibilidad de sustitutos cercanos. & Alta & & & & & & Alta \\
\hline Suficientes proveedores. & Alta & & & & & & Alta \\
\hline
\end{tabular}

Nota. Adaptado de Estrategia para el Liderazgo Competitivo (p. 78), por A.Hax y N. Majluf, 1998, Granica, España: Prentice Hall. Copyrigth 1998 por Ediciones Granica. 


\subsubsection{Potenciales - Entrada potencial de nuevos competidores.}

Se consideró ocho variables para la fuerza competitiva "Entrada Potencial de Nuevos Competidores" que afectan a Incas Jewelry S.A.C (ver Tabla 12). Como resultado de este análisis se determinaron tres amenazas. "A8. Existencia de empresas virtuales”, ubicada y detallada en "Ventaja de la curva de aprendizaje", "A6. Limitado apoyo de la cámara de comercio", ubicado y detallado en "Requerimiento de capital" y "A3. Economía de escala de las grandes tiendas", ubicadas y detalladas en "Valor de la marca".

Tabla 12

Matriz de Atractividad de la Fuerza "Entrada Potencial de Nuevos Competidores".

\begin{tabular}{llll}
\hline & & Baja & Baja \\
\hline Existencia de barreras a la entrada & Media & Baja & Baja \\
Requerimiento de capital & Baja & Baja \\
Diferenciación de producto & Baja & Alta \\
Costos de cambio & Baja & Baja \\
Valor de la marca & Alta & Baja & Alta \\
Acceso a la distribución & Alta & &
\end{tabular}

Nota. Adaptado de Estrategia para el Liderazgo Competitivo (p. 78), por A.Hax y N. Majluf, 1998, Granica, España: Prentice Hall. Copyrigth 1998 por Ediciones Granica.

\subsubsection{Clientes - Poder de negociación de los consumidores.}

Poder de negociación de los consumidores presentó atractividad media, a pesar de que existe una alta disponibilidad de información para el comprador en cuanto a precios, modelos, lugares de compra, especialmente por las redes sociales, a su vez cuando una empresa registra bajas utilidades de ser percibido por el cliente denotaría desinterés por parte del consumidor final por un tema de desconfianza (ver Tabla 13). Como resultado de este análisis se determinaron tres oportunidades: “O4. Alto poder adquisitivo de clientes extranjeros" y "O7. Posicionamiento de los diseños étnicos peruanos a nivel mundial” ubicado y detallado en "Disponibilidad de información para el comprador; "O3. Alta demanda de compradores locales de joyas" ubicado y detallado en "Volumen del 
comprador”. Asimismo, se determinó una amenaza: “A9. Piratería de diseños”, ubicada y detallada en "Sensibilidad del comprador al precio".

Tabla 13

Matriz de Atractividad de la Fuerza "Poder de Negociación de los Consumidores".

\begin{tabular}{|c|c|c|c|c|c|c|c|}
\hline & & 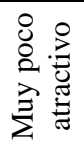 & 递 & 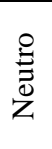 & 总 & 怘总 & \\
\hline $\begin{array}{l}\text { El producto comprado no representa parte } \\
\text { importante de sus compras }\end{array}$ & Baja & & & & & & Alta \\
\hline $\begin{array}{l}\text { Disponibilidad de información para el } \\
\text { comprador. }\end{array}$ & Alta & & & & & & Baja \\
\hline $\begin{array}{l}\text { Grado de dependencia de los canales de } \\
\text { distribución. }\end{array}$ & Alta & & & & & & Alta \\
\hline Volumen del comprador. & Media & & & & & & Alta \\
\hline $\begin{array}{l}\text { Costes o facilidades del cliente de cambiar de } \\
\text { empresa. }\end{array}$ & Alta & & & & & & Alta \\
\hline Existencia de productos sustitutos. & Baja & & & & & & Alta \\
\hline Sensibilidad del comprador al precio & Alta & & & & & & Alta \\
\hline
\end{tabular}

Nota. Adaptado de Estrategia para el Liderazgo Competitivo (p. 78), por A.Hax y N. Majluf, 1998, Granica, España: Prentice Hall. Copyrigth 1998 por Ediciones Granica.

\subsubsection{Proveedores - Poder de negociación de los proveedores.}

Se consideró cinco variables para la fuerza competitiva "Poder de Negociación de los Proveedores" que afectan a Incas Jewelry S.A.C (ver Tabla 14). Como resultado de este análisis se determinó una amenaza: “A4. Alza de precio de los insumos”, ubicado y detallado en "Coste de los productos del proveedor en relación con el coste del producto final"

Tabla 14

Matriz de Atractividad de la Fuerza "Poder de Negociación de los Proveedores".

\begin{tabular}{|c|c|c|c|c|c|c|c|}
\hline & & 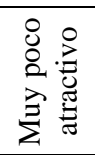 & 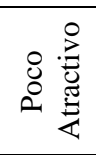 & $\begin{array}{l}\text { 巳 } \\
\text { ¿゙ } \\
\text { Z }\end{array}$ & 莺 & 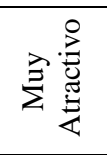 & \\
\hline $\begin{array}{l}\text { Sector dominado por pocas empresas } \\
\text { proveedoras }\end{array}$ & Alta & & & & & & Alta \\
\hline $\begin{array}{l}\text { El producto es diferenciado o tiene altos costos } \\
\text { por cambio }\end{array}$ & Baja & & & & & & Baja \\
\hline Presencia de productos sustitutivos & Alta & & & & & & Alta \\
\hline Concentración de los proveedores & Alta & & & & & & Baja \\
\hline $\begin{array}{l}\text { Coste de los productos del proveedor en relación } \\
\text { con el coste del producto final. }\end{array}$ & Alta & & & & & & Alta \\
\hline
\end{tabular}




\subsubsection{Competencia en el mismo sector - Rivalidad entre empresas competidoras}

Se consideraron ocho variables para la fuerza competitiva "Rivalidad entre Empresas Competidoras” que afectan a Incas Jewelry S.A.C. (ver Tabla 15). La rivalidad entre empresas nace precisamente porque existe un gran poder por obtener a los mejores proveedores, la existencia de un crecimiento industrial, deseos por posicionar su marca. En ese caso tiene una atractividad alta. Como resultado de este análisis se pudo determinar tres oportunidades: "O1. Existencia de TLC con países con alto potencial de compradores y proveedores", ubicado y desarrollado en "Crecimiento industrial"; "O6. Potencial de las redes sociales para comercializar productos" ubicado y desarrollado en "Poder de los compradores", “O6. Existencia de ferias", ubicado y desarrollado en "Identidad de la marca". Y tres amenazas: “A1. Presencia de grandes marcas”, ubicado y desarrollado en "Amenaza de nuevos competidores"; “A2. Presencia de mayoristas", ubicado y desarrollado en "Poder de los proveedores" y “A6. Alta informalidad en el sector", ubicado y desarrollado en "Diversidad de los competidores".

Tabla 15

Matriz de Atractividad de la Fuerza "Rivalidad entre Empresas Competidoras".

\begin{tabular}{llll}
\hline & & Alta & \\
\hline Poder de los competidores. & & Baja \\
Poder de los proveedores & Baja & & Rápido \\
Crecimiento industrial & Blta & & $\begin{array}{l}\text { Producto } \\
\text { especial }\end{array}$ \\
$\begin{array}{l}\text { Diversidad de competidores. } \\
\text { Poder de los compradores }\end{array}$ & Baja & Baja \\
Amenaza de nuevos competidores. & Baja & & Baja \\
Amenaza de productos sustitutivos & Alta & & Alta \\
Identidad de la marca & Alta & Alta \\
\hline
\end{tabular}

Nota. Adaptado de Estrategia para el Liderazgo Competitivo (p. 78), por A.Hax y N. Majluf, 1998, Granica, España: Prentice Hall. Copyrigth 1998 por Ediciones Granica.

\subsection{Análisis del Grado de Atractividad de la Industria}

Este análisis resume el análisis que hemos hecho, respecto a las cinco fuerzas de Porter, dando una calificación global del nivel de atractividad de la industria joyera. Se procede a analizar las tablas por variables destinadas en cada una de las fuerzas: 


\subsubsection{Sustitutos - Desarrollo potencial de productos sustitutos.}

Actualmente el desarrollo potencial de productos sustitutos presenta una atractividad alta pues estos productos están disponibles en el mercado, tales como oro, diamantes, perlas, níquel, platería, níquel, bisutería, joyas traídas de China y la producción de la plata trucha, para protegerse de estas empresas proveedoras de productos sustitutos, la industria de joyas opta por diversificar sus joyas combinándolas con otros productos. En el mercado siempre existirán productores que sacan plata trucha, es decir, mezclada con otros minerales, perdiendo así la pureza del producto y el comprador lo adquiere incluso a veces sabiendo que no es de calidad. Para el 2022 también se pronostica una atractividad alta, pues el TLC favorece la exportación. Se procede a describir el nivel de atractividad de las variables de esta fuerza

- Tendencia del comprador a sustituir: Esta tendencia del comprador tiene atractividad alta, el cliente finalmente es quien decide que comprar, pueden gustar de una joya de plata 950 o quizá 925 , o joyas cuyas piezas están combinadas con múranos que son más simples y baratos o quizá bisutería. $\mathrm{O}$ en su caso irse al extremo y llevar una joya de precio elevado como oro, diamantes y demás. Otro mercado interesante es China y Hong Kong quienes están experimentando con productos de otras culturas, según expertos de Mincetur.

- Precios relativos de los productos sustitutos: La tendencia en el precio de los precios de los productos sustitutos es de atractividad alta, pues está ingresando mucha joya china o insumos chinos de bajo costo. Tienen incluso ventas vía internet y llegan al Perú con mucha facilidad. Por otro lado Turquía, China y Hong Kong son potenciales nuevos mercados para la joyería peruana (Julio Pérez, Asociación de Exportadores, 2017), lo que significa que los precios de las joyas de China tenderían a bajar mucho más.

- Coste o facilidad de cambio del comprador: La tendencia de que un comprador cambie su estado de compra resulta tener una atractividad alta, porque la joya no es un producto de primer nivel de consumo, utilizan su dinero para comprar otros productos de canasta familiar. Pero por otro lado está la persona que le gusta vestir bien y lucir accesorios de plata, que por su larga vida suelen adquirirlos.

- Nivel percibido de diferenciación de producto o servicio: Considerándose los productos sustitutos el oro, diamantes, perlas, joyas de níquel, cobre y bisutería, 
como accesorios de moda, el cliente percibe la diferencia en el precio y el beneficio que obtiene al usarlo, por lo tanto, tiene un nivel de atractividad baja.

- Disponibilidad de sustitutos cercanos: La disponibilidad de obtener productos sustitutos tiene atracción alta, sumándose a que el comprador tiene una alta tendencia a sustituir sus productos, incluso manejan gemas de colores muy similares a las peruanas, pero su costo es más bajo porque son artificiales, pero no son fácilmente diferenciadas debido a la alta tecnología que utilizan en su proceso de producción.

- Suficientes proveedores: Existe una alta atractividad en los proveedores que ingresan con productos chinos, se sabe que muchos productos chinos reingresan al Perú, es decir, ellos llevan las piedras peruanas en bruto, las trabajan y las venden al Perú nuevamente con diseños que mueven el mercado.

\subsubsection{Potenciales - Entrada potencial de nuevos competidores.}

La entrada potencial de nuevos competidores en la actualidad tiene una atractividad baja puesto que el competidor actual siempre va a existir, sin ellos significa que el negocio no marcha bien, una de las variables existentes en el mercado de la joyería es mantener un stock siempre renovado, lo cual implica tener capital para poder adquirirlos, lo que demuestra que tenemos un atractivo potencial de competidores. Al 2022 el consumidor muestra una atractividad lenta, la idea actual es venderle la necesidad del cliente, esto dependerá de cuan innovador se muestre la tienda, los productos, sus diseños y sobretodo calidad que pueda demostrar, lo que detiene este paso es la poca tecnología con la que se trabaja en el Perú. Se procede a describir el nivel de atractividad de las variables de esta fuerza:

- Existencia de barreras a la entrada: La existencia de barreras para el ingreso de nuevos competidores en la industria de la joyería es de atractividad bajo, la mayoría de las empresas prefieren ser informales, pues la mayoría de los artesanos de las pymes desarrollan su actividad a baja escala. Salvo que mejoren los estatutos para ayudar a las pymes esto se mantendrá en bajo.

- Requerimiento de capital: El requerimiento de capital para ingresar a la industria de las joyas maneja un perfil de atractividad media, pues los insumos utilizados en la producción son altos incluso la tecnología que se requiere para la elaboración y producción requiere técnicas profesionales que son caras. Más las maquinas que se utilizan son antiguas y la mayoría de las joyas se hacen de manera artesanal. Se estima que esto se mantenga de esta manera. 
- Diferenciación de producto: Esta diferenciación es de atractividad baja, puesto que los consumidores no logran una diferenciación en el sector; los mismos artesanos pueden trabajar con uno u otro joyero con ambos, haciendo que los productos que ofrezcan la industria se mantenga en el mismo nivel de competitividad.

- Costos de cambio: El costo de cambiar de empresa o de artesano es de atractividad baja. La industria de la joyería en el Perú maneja cambios en la materia prima, en la elaboración del diseño, producción y distribución.

- Valor de la marca: El valor de la marca representa una atractividad baja en el sector de la joyería de las pymes puesto que el consumidor no diferencia la marca en este sector, más si lo hace con empresas grandes cuya marca están posicionadas en el mercado no solo peruano sino de manera internacional.

- Acceso a la distribución: La industria joyería muestra una atractividad alta, puesto que ya existe apoyo de servicio de Courier como DHL, Olva Courier, Serpost manejan tarifas locales y nacionales para el traslado específicamente de joyas, que oscilan entre S/.6 y S/.10 por 30 gr de peso en el paquete. El consumidor tiende a comprar con servicio delivery.

- Ventajas de la curva de aprendizaje: Esta tendencia es de atractividad baja, la industria joyería mantiene una línea de aprendizaje constante, si bien los diseños de los modelos cambian, el método de aprendizaje por parte de los artesanos en su mayoría es copiado por los más antiguos y en las académicas donde se aprende este oficio no ha presentado gran innovación.

- Políticas gubernamentales: El nivel de atractividad de las políticas gubernamentales del Perú son altas, las personas tienden a emprender en los negocios pymes y se espera un crecimiento del $3.5 \%$ este 2017 , de acuerdo a una muestra de 140 pymes el 58\% dice que la situación podría mejorar este año INEI, (2018)

\subsubsection{Clientes - Poder de negociación de los consumidores.}

El poder de negociación de los consumidores es alto debido a que en la industria de la joyería como cualquier otro negocio el consumidor es quien fija los precios que se maneja siempre debido a la economía de escala y al 2022 esta atractividad es más rápida debido a que los consumidores tienen mayores exigencias en los productos que compra. Se procede a describir el nivel de atractividad de las variables de esta fuerza:

- El producto comprado no representa parte importante de sus compras: Esta variable tiene una atractividad baja puesto que para el consumidor la industria de 
la joyería no representa un bien de primera necesidad. Pero la tendencia es alta debido a que las personas se preocupan mucho en lucir accesorios de calidad en su vida laboral o social.

- Disponibilidad de información para el comprador: El poder de negociación del consumidor frente a tanta información existe para él tiene una atractividad alta, hoy en día las redes sociales por ejemplo causan un gran impacto social y tecnológico, se puede ubicar direcciones, facilidades como google maps de cómo llegar, referencias del producto, el cliente puede evaluar su compra sirviendo de referente a un cliente nuevo. El pronóstico de esta variable a futuro es alto.

- Grado de dependencia de los canales de distribución: Esta variable dentro del poder de negociación de los consumidores tiene una atractividad alta debido a que los consumidores están acostumbrados a obtener sus productos inmediatamente estos generan su orden de compra.

- Volumen del comprador: Esta variable tiene una atractividad media, debido a que un mismo cliente en promedio, aporta a la industria de la joyería cada tres meses. En este punto también están las personas con empresa que compran en volúmenes altos con la finalidad de vender piezas conocidas a sus contactos.

- Costes o facilidades del cliente de cambiar de empresa: Esta variable representa una atractividad alta, debido a que el consumidor no necesariamente mantiene un nivel de fidelidad a una sola empresa, es gracias a ello que la competencia existe, se manejan con costos distintos.

- Existencia de productos sustitutos: Esta variable presenta una atractividad baja, la industria joyera tiene la necesidad de darle mayor valor agregado a los minerales peruanos, Adex señaló que Perú transforma el 7\% u 8\% de su producción de plata, debido al ingreso de productos sustitutos de China y Hong Kong. Y se pronostica para el 2022 esta tendencia sea alta, debido a los tratados que se están firmando.

- Sensibilidad del comprador al precio: Esta variable tiene una atractividad alta. Esto se debe a que el comprador es usualmente quien establece el precio en el mercado. Se pronostica que al 2022 esto continúe.

\subsubsection{Poder de Negociación de los proveedores.}

El poder de negociación de los proveedores es alto debido a que en la industria de la joyería la plata es uno de los metales de mayor cotización en el mercado, es por ello la aparición de diversos proveedores de esta materia prima, que en su mayoría son informales, porque las grandes empresas proveedoras prefieren exportar este metal. Al 2022 se provee 
una atractividad de producto especial, es decir, los proveedores para estar frente a este mercado tendrán que sofisticar sus procesos de atracción de la plata a fin de obtener alguna certificación para que las empresas puedan adquirirla y así garantizar la calidad del producto. Se procede a describir el nivel de atractividad de las variables de esta fuerza

- Sector dominado por pocas empresas proveedoras: El poder de negociación con las empresas proveedoras es alto, porque las grandes empresas mineras prefieren exportar sus productos antes que vender al mercado nacional, motivo por el cual mayoría de los joyeros se abastecen de la minería informal.

- El producto es diferenciado o tiene altos costos por cambio: El poder de negociación con los artesanos es bajo, de los 3000 talleres artesanales de joyería inscritos en el Registro Nacional de Artesanos del Ministerio de Comercio Exterior y Turismo (MINCETUR) están debidamente capacitados en los institutos de joyas como CITES10

- Presencia de productos sustitutivos: El poder de negociación con los proveedores de productos sustitutos es alta, puesto que los proveedores de plata, oro piedras y gemas nativas en su mayoría son informales, sus productos varían desde precios muy altos hasta los más bajos y diseños exclusivos a copiados por otras tiendas conocidas en el mercado. Es de gran importancia el costo de los productos de los proveedores porque de eso depende la utilidad que deja cada producto vendido.

- Concentración de los proveedores: El poder de negociación de los proveedores de la materia prima como la plata piña es alta, por ser un producto commodity, ya que estos precios los rige el mercado, considerando que en el Perú hay bastante minería informal. El 14\% de la producción son destinados a la industria joyera, no formalizan porque significaría sacrificar costos en el proceso productivo pues los impuestos se llevan el $18 \%$.

- Coste de los productos del proveedor en relación con el coste del producto final: El poder de negociación de los proveedores en relación con el coste del producto final presenta una atractividad media alta considerando el costo de los productos del proveedor en relación con el costo del producto final, puesto que, si un

\footnotetext{
${ }^{10}$ CITE: Los CITE Artesanales y Turísticos son instituciones cuyo objetivo principal es elevar la competitividad de la producción artesanal en los mercados externos, internos y turísticos. Para ello realizan un trabajo conjunto con los artesanos, con las asociaciones que los agrupan y con las empresas del rubro.

(https://www.mincetur.gob.pe/turismo/lineas-de-intervencion/desarrollo-de-la-artesania/centros-de-innovaciontecnologica-cites/)
} 
producto que ofrece un proveedor es alto, indudablemente el precio final tiene que ser alto para dejar utilidad en la empresa.

\subsubsection{Competencia en el mismo sector - Rivalidad entre empresas competidoras.}

Actualmente esto muestra una atractividad alta debido a que las empresas joyeras usualmente colocan sus tiendas incluso sus talleres de producción en la misma zona con la finalidad de generar alianzas y prestarse recursos, tanto humanos como artesanos y diseñadores como maquinas, que al ser muy antiguas estas se malogran de manera continua. Luego de analizar cada una de las fuerzas, se realizó una evaluación global, obteniendo como resultado de las cinco fuerzas, cuatro de ellas tiene un grado de atractividad alta en la industria de la joyería, tales como: Desarrollo potencial de productos sustitutos Rivalidad entre empresas competitivas, Poder de negociación de compradores y poder de negociación de los proveedores. Y se tiene un grado de atractividad bajo en la entrada potencial de nuevos competidores. Se procede a describir el nivel de atractividad de las variables de esta fuerza:

- Poder de los competidores: Esta variable tiene una atractividad alta, pues existe una agrupación de empresas de mismo rubro y que en su mayoría colocan sus tiendas en el mismo distrito, esto se debe a que muchos de ellos tienen varias sucursales.

- Poder de los proveedores: Esta variable tiene una atractividad baja, en la industria de la joyería los proveedores locales tienen bajo poder pues la mayoría al ser informales no toman decisiones en los precios de sus insumos.

- Crecimiento industrial: Esta variable tiene una atractividad baja, la industria de la joyería está creciendo de manera moderada, en su mayoría las empresas que están surgiendo trabajan con maquinaria antigua y los joyeros trabajan de manera artesanal.

- Diversidad de competidores: Esta variable tiene una atractividad es alta debido a que la industria de la joyería se está diversificando en sus productos, mezclando en una pieza diversos materiales que los hacen atractivos y algunos manejan precios bajos.

- Poder de los compradores: Esta variable tiene una atractividad alta, en la industria de la joyería el comprador tiene un alto poder sobre el producto o precio que compran.

- Amenaza de nuevos competidores: Esta variable tiene una atractividad media, los joyeros y artesanos están acostumbrados al ingreso de nuevos competidores y en 
su mayoría son familia y forman alianzas entre ellos. Es muy común que se presten las maquinas, incluso diseñadores y artesanos.

- Amenaza de productos sustitutivos: Esta variable tiene una atractividad alta, porque una amenaza constante en la industria de la joyería debido al ingreso de productos provenientes de la China, Hong Kong, Panamá y otros.

- Identidad de la marca: Esta variable tiene una atractividad alta, uno de los grandes retos en los que se enfrenta la industria joyera es posicionar su nombre, su marca, porque su intención en poder exportar.

Para culminar este punto se procede en la tabla 16 se generó la tabla donde se muestra la Matriz de Atractividad de las cinco fuerzas de Porter y el análisis respectivo de manera general

Tabla 16

Matriz de Atractividad de las Cinco Fuerzas.

\begin{tabular}{|c|c|c|c|c|c|c|c|}
\hline & & 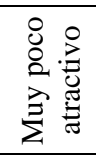 & ○. & 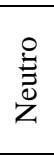 & 总 & 怘怘 & \\
\hline Desarrollo potencial de productos sustitutos & Alta & & & & & & Alta \\
\hline Entrada potencial de nuevos competidores & Baja & & & & & & Lento \\
\hline Poder de negociación de los consumidores & Alta & & & & & & Rápida \\
\hline Poder de negociación de los proveedores & Alta & & & & & & Producto \\
\hline Rivalidad entre empresas competidoras & Alta & & & & & & $\begin{array}{l}\text { especial } \\
\text { Alta }\end{array}$ \\
\hline
\end{tabular}

Nota. Adaptado de Estrategia para el Liderazgo Competitivo (p. 78), por A.Hax y N. Majluf, 1998, Granica, España: Prentice Hall. Copyrigth 1998 por Ediciones Granica.

\subsection{Matriz de Perfil Competitivo MPC}

En 2012, Porter analizó la Matriz del Perfil Competitivo (MPC) y es por ello que se entrevistó a dos empresas del mismo rubro, tamaño similar al de Incas Jewelry. Para realizar esta matriz se analizaron las respuestas realizadas a la Gerente General de la empresa (ver Apéndice A1), a un experto en la Industria (ver Apéndice A5), al Gerente General de una empresa competencia (ver Apéndice A6) y a la Administradora de Tienda de la Competencia en una entrevista en profundidad (ver Apéndice A7).

Para el desarrollo de esta matriz los factores críticos de éxito fueron sugeridas por un experto de la industria a quien se le mostró una lista extraída del libro de David, él retiró algunas y añadió: Estilo, referido a que toda joyería debe tener un sello característico; 
Confiabilidad, relacionado a la exclusividad de los diseños que el cliente solicita y

Puntualidad, relacionada al cumplimiento de los plazos del producto final. Todos estos factores fueron calificados del 1 al 10, siendo 1 el menos importante y 10 el más importante, porque era la manera más simple de calificarla y luego se pasó a una tabla de tabulaciones para llegar a 1. Del mismo modo se pidió a Joyas M\&F y Spondylus calificaran estos mismos factores indicando si son fortaleza mayor (4); Fortaleza menor (3); Debilidad menor (2) o debilidad mayor (1) para de esta forma poder determinar el tipo de ventaja competitiva de cada una de las industrias. Estas entrevistas fueron solicitadas en una segunda entrevista y para el caso de Incas Jewelry se hizo el llenado en una de las reuniones semanales que los socios realizan. Con lo cual se puede observar que Spondylus tiene una ponderación de 3.51, el cual supera el 2.5 que es la media aceptada según Porter, representando ser competencia directa porque tiene mejor posicionamiento demostrando que sus capacidades proporcionan una mejor ubicación defensiva en función de las fuerzas competitivas existentes de Incas Jewelry, seguidas por Joyas M\&F (ver Tabla 17).

Tabla 17

Matriz de Perfil Competitivo - MPC Incas Jewelry Joyas M\&F $\quad$ Spondylus

Factores claves de éxito

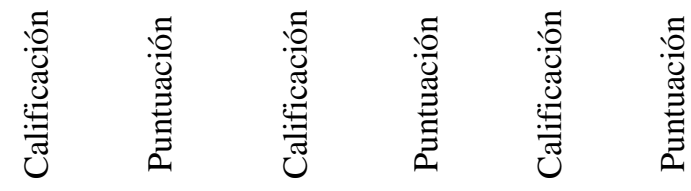

\begin{tabular}{llllllll}
\hline Publicidad & 0.06 & 1 & 0.06 & 3 & 0.18 & 4 & 0.24 \\
Calidad de productos & 0.08 & 4 & 0.32 & 4 & 0.32 & 4 & 0.32 \\
Estilo & 0.09 & 4 & 0.36 & 3 & 0.27 & 3 & 0.27 \\
Competitividad de precios & 0.07 & 1 & 0.07 & 3 & 0.21 & 4 & 0.28 \\
Reconocimiento de marca & 0.06 & 2 & 0.12 & 2 & 0.12 & 4 & 0.24 \\
Lealtad del cliente & 0.05 & 1 & 0.05 & 3 & 0.15 & 2 & 0.10 \\
Variedad de productos & 0.06 & 3 & 0.18 & 4 & 0.24 & 4 & 0.24 \\
Confiabilidad & 0.09 & 4 & 0.36 & 2 & 0.18 & 3 & 0.27 \\
Capacidad de producción & 0.07 & 2 & 0.14 & 4 & 0.28 & 4 & 0.28 \\
Comercio electrónico & 0.07 & 1 & 0.07 & 1 & 0.07 & 4 & 0.28 \\
Servicio postventa & 0.06 & 4 & 0.24 & 3 & 0.18 & 3 & 0.18 \\
Promociones & 0.07 & 1 & 0.07 & 3 & 0.21 & 3 & 0.21 \\
Canales de distribución & 0.09 & 1 & 0.09 & 4 & 0.36 & 4 & 0.36 \\
Puntualidad & 0.08 & 4 & 0.32 & 3 & 0.24 & 3 & 0.24 \\
\hline Total & 1.00 & & 2.45 & & 3.01 & & 3.51
\end{tabular}

Nota. Fortaleza mayor (4); Fortaleza menor (3); Debilidad menor (2) o Debilidad mayor (1). Tomado de Conceptos de Administración Estratégica (p. 83), por F. David, 2013, México, D.F., México: Prentice Hall. Copyrigth 2000 por Pearson Education. 


\section{Capítulo VI: Análisis Interno}

En este capítulo se describe las actividades de la cadena de valor de la empresa Incas Jewelry SAC, los datos descritos han sido extraídos de las entrevistas en profundidad realizadas a personal interno de la empresa. Para poder determinar las ventajas competitivas de la empresa se entrevistó a dos empresas que venden productos similares y con los datos obtenidos se pudo obtener los factores de éxito cuyas actividades los hacen mejores a la empresa Incas Jewelry. Con los datos obtenidos se logró determinar las fortalezas y debilidades que fueron revisadas por el gerente general, obteniendo su aprobación.

\subsection{Descripción de las Actividades de la Cadena de Valor de la Empresa:}

En 2013, David señaló que la cadena de valor es la mejor forma de ver la empresa, en la cual los ingresos totales menos los costos totales de todas las actividades emprendidas para desarrollar y comercializar un producto o servicio producen valor. Todas las empresas de una industria específica cuentan con una cadena de valor similar, la cual cuenta con actividades como la obtención de materia prima, el diseño de productos, la construcción de instalaciones, los acuerdos de cooperación y servicio al cliente". (p.119). "Según esta herramienta también, todas las empresas cuentan con una cadena de valor conformada por estas actividades que van desde el diseño del producto y la obtención de insumos hasta la distribución del producto y los servicios de post venta.”. Las actividades primarias o de línea, son las relacionadas con la producción y comercialización de joyas de plata. Para realizar la descripción adjunta fue necesario llevar a cabo una entrevista en profundidad a personal interno (ver Apéndice A). Se procede a describir todas las actividades (ver Tabla 18):

- Logística interior (de entrada): La empresa no tiene un área de logística, no se cuenta con almacén, todo se guarda en la tienda y en un repositorio en el domicilio del Gerente General, quien es uno de los dueños de la empresa. La Gerente de Tienda, es quien realiza las actividades relacionadas con la compra, recepción, almacenaje y distribución de los insumos como la plata, piedras naturales o gemas las cuales se guaran en la tienda. La plata ingresa a la tienda según los pedidos realizados según demanda de clientes. Las piedras y gemas son adquiridas a proveedores de alta confianza que llegan a la tienda y son de diversas regiones del Perú, la pirita la traen de Quiruvilca, Rodocrocita de Anchash, Crisocola de Ica, etc. Por otro lado, no se lleva ningún tipo de control del ingreso de estos productos ni tampoco de los demás. Debido a que la industria de la joyería ha ido 
Tabla 18

Cadena de Valor de Incas Jewelry

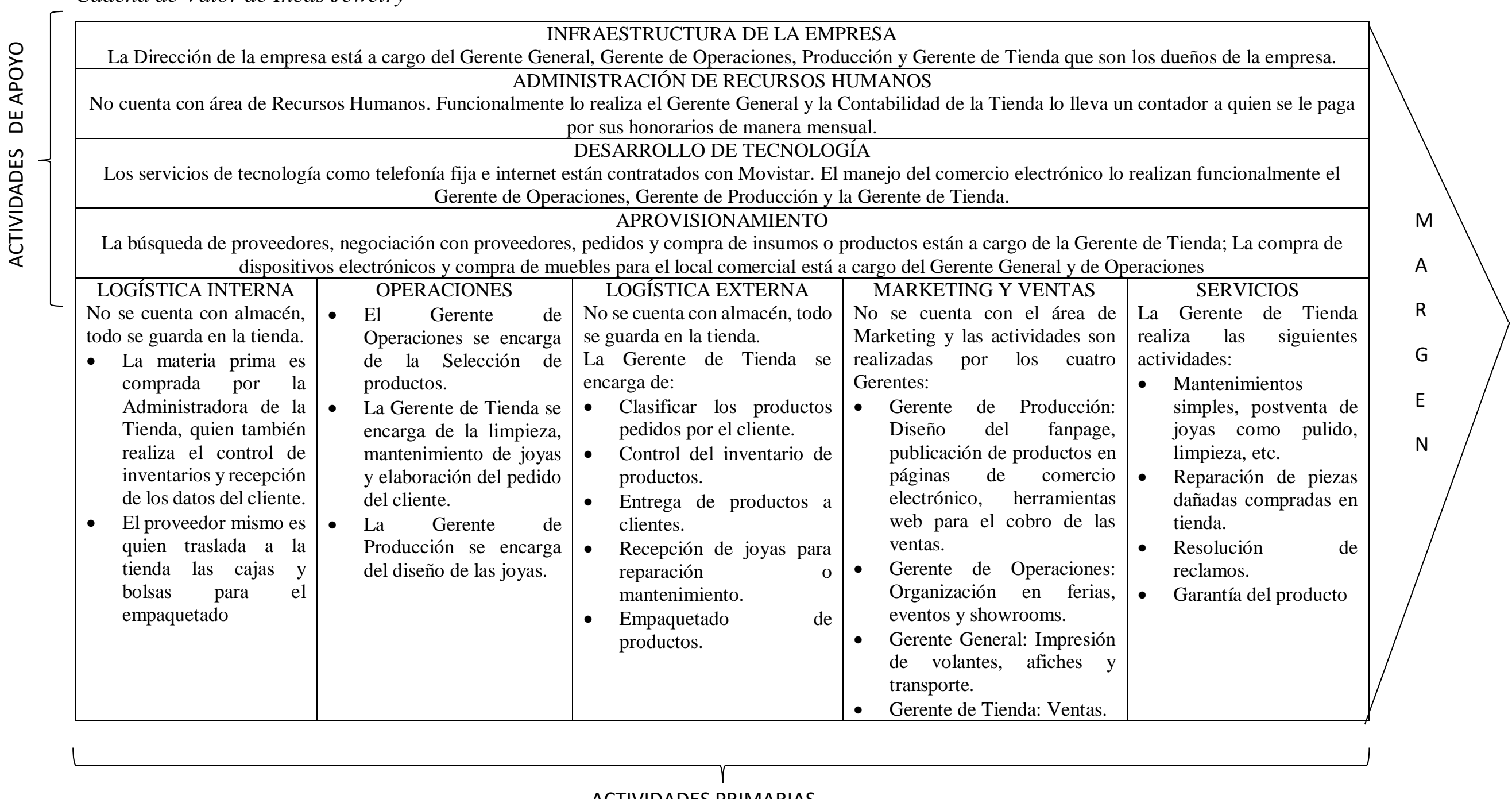

ACTIVIDADES PRIMARIAS

Nota. Tomado de Conceptos de Administración Estratégica (p. 120), por F. David, 2013, México, D.F., México: Prentice Hall. Copyrigth 2000 por Pearson Education. 
mejorando, la empresa también ha ido mejorando sus procesos de producción o adquisición de piezas únicas a proveedores. Para ello se tiene en cuenta los clientes que suelen pedir este tipo de trabajo para darles la prioridad en venta. Los empaques y cajas, son elaborados a la medida y el proveedor mismo es quien las deja en la tienda. Ahí mismo es donde se solicita el requerimiento. Por lo expuesto en este punto se encuentra la fortaleza: "F1. Insumos de buena calidad".

- Operaciones: El Gerente de Operaciones se encarga de seleccionar al proveedor de mayor confianza. La Gerente de Producción elabora el diseño de las piezas únicas de la tienda utilizando cuños, por lo que esta producción salen por lotes grandes, una vez obtenida la muestra se hacen las muestras en ceras y salen por bloques y cantidades de 10 o 15 unidades, las piezas únicas dependiendo de su complejidad es realizada en un máximo de tres días, con el fin de ahorrar costos en alquiler de talleres, esta tarea se está tercerizando desde este año con artesanos de confianza, el procedimiento artesanal (sin cuño) encarece la pieza, pues su mismo proceso tiene un costo alto, por lo que su producción es baja. La Gerente de Tienda se encarga de dar mantenimiento de las joyas o piezas que se encuentran en vitrina para que luzcan brillosas y también realiza simples mantenimientos a las joyas de los clientes que compraron en tienda, así como la elaboración del pedido del cliente cuando solicita una pieza a la medida. Por lo expuesto en este punto se encuentran la oportunidad: "F2. Diseño de productos a medida" y tres debilidades: “D1. Baja automatización de procesos", "D2. Alto costos de producción” y "D3. Portafolio limitado de joyas"

- Logística exterior (de salida): No se cuenta con almacén, todo lo referente a las joyas y productos se encuentran y guardan en tienda. La Gerente de Tienda se encarga de clasificar los productos solicitados por el cliente ya sea por web, whatsapp o los que visitan la tienda directamente. Asimismo, es quien entrega los productos debidamente empacados y luego lista en el cuaderno de control de ventas las piezas vendidas canceladas en efectivo o con tarjeta. De existir una joya que pasa a reparación, ella lo recibe verificando que cumpla con las políticas de garantía.

- Marketing y ventas: La empresa no cuenta con el área de Marketing, esta tarea es realizada por los cuatro gerentes y dueños del negocio. La Gerente de Producción con conocimientos básicos en este punto se encarga del diseño del fanpage publicación de productos en páginas de comercio electrónico, herramientas web 
para el cobro de las ventas. El Gerente de Operaciones se encarga de separar las fechas en las ferias, eventos y showrooms. organizadas por la Cámara de Comercio u otras entidades, pero no le dedica demasiado tiempo en esta función. El Gerente General se encarga de contratar la impresión de volantes o afiches. No manejan ningún sistema con los sistemas de los clientes, salvo el del sistema de cobranza, pues se trabaja con todas las tarjetas VISA y Mastercard. Por lo expuesto en este punto se encuentran tres debilidades: "D3. Portafolio limitado de joyas", "D4. Bajo aprovechamiento del comercio electrónico" y "D5. Reducida participación en ferias del rubro"

- Servicios de post venta: La Gerente de Tienda es la encargada de brindar el servicio de posventa como mantenimiento simple de las piezas, como pulido, limpieza, achicar o agrandar una joya. Resuelve los reclamos simples suscitados en la tienda, siempre y cuando cumpla con las políticas de garantía, como por ejemplo que la pieza ya no brille, si está la presentan rota o rallada se cobra por el servicio porque esta fue maltratada. Ella está autorizada a entregar pequeñas un presente al comprador con la intención de crear fidelidad.

- Las actividades apoyo o soporte, son aquellas que agregan valor al producto, pero no están relacionadas directamente con la producción del mismo. Por lo expuesto en este punto se encuentran la fortaleza: "F3. Cumplimiento de estándares de la industria joyera"

- Aprovisionamiento: Las diversas áreas de la empresa en su mayoría cuentan con los implementos básicos que los ayudan a realizar sus funciones básicas. Es una necesidad de ellos mantener los lineamientos básicos de higiene en el taller, la tienda, no solo por un tema de imagen sino de seguridad. Los insumos utilizados son cuidadosamente guardados para que la producción de las joyas sea limpia y guardando los estándares de calidad. La Gerente de Tienda es la encargada de buscar los mejores proveedores y hace el trato directamente con ellos, negociando los precios, realiza el pedido y compra de los productos. Por lo expuesto en este punto se encuentran la fortaleza: "F4. Alianzas con proveedores"

- Desarrollo de la tecnología: Desde este año la producción de las piezas la empresa contrata a ciertos profesionales que trabajan con tecnología como selladoras, calados en 3D, maquinas con las que la empresa no cuenta y tampoco se encuentra capacitada. Por otro lado, existe un mal uso del comercio electrónico, fanpage, el medio más efectivo para la tienda es el whatsapp. El registro de operaciones, 
gestión y ventas se realizan de manera manual en un cuaderno. Para el cobro de los productos se utiliza el POS de Visa y Mastercard. Por lo expuesto en este punto se encuentran la fortaleza: "F5. Disponibilidad de diversos medios de pago"

- Administración de recursos humanos: No existe área de recursos humanos al ser una empresa familiar y por estar en su tercer año no ha habido aumento de salario. Esto no impide que el personal cuente con todas sus prestaciones de ley, como sueldo, cts, gratificaciones, seguro, afp. El personal también cuenta con capacitaciones que lo ayudan en el desenvolvimiento de sus funciones. Los empleados en planilla son dos, pero funcionalmente se unen tres personas más con sus propias responsabilidades llevando una relación basada en la confianza, credibilidad y compromiso. Asimismo se tercerizan ciertos trabajos de producción a artesanos conocidos por su profesionalismo trabajando el arte de la plata y con quienes se tiene una muy buena relación laboral. Por lo expuesto en este punto se encuentran las fortalezas: "F6. Empleados comprometidos" y "F7. Mano de obra calificada"

- Infraestructura de la empresa: La empresa está formalmente constituida, tiene un solo local. Este es alquilado en el distrito de Miraflores, es una galería de puestos artesanos, las tiendas están divididas por productos, como carteras de cuero, mantos, arte de madera, madera con plata, tejidos y otros. La persona que atiende en la tienda es familia de la empresa, es quien administra y contacta con los diversos proveedores. Sin embargo, la tienda no cuenta con taller, alquilar por horas las maquinas. La administración de la tienda es llevada por la Gerente de Tienda, las finanzas las lleva el Gerente General, los libros contables los lleva un contador a quien se le paga una tarifa única mensual, el planeamiento de las operaciones, los costos y presupuestos se plantean en las reuniones bimensuales. El personal no cumple con un horario fijo, es parcial. Por lo expuesto en este punto se encuentra la fortaleza: "F8. Empresa constituida" y las debilidades "D6. Carencia de taller propio", "D7. Limitada capacidad financiera" y "D8. Dedicación de personal a tiempo parcial”.

\subsection{Indicadores de cada una de las Actividades de la Cadena de Valor}

Se procede a mencionar los indicadores de las actividades primarias y de apoyo de la empresa, los datos fueron tomados de las entrevistas en profundidad al personal interno y luego fueron verificadas por ellos (ver Apéndice A y Tabla 19). Incas Jewelry SAC no trabaja con variables KPI de cumplimientos y solo se ha considerado datos que se utilizan como 
control para trabajar los costos ventas de manera interna porque aún no se cuenta con objetivos comerciales ni operativos. Se espera que al finalizar el plan estratégico se coloquen los lineamientos necesarios que aporten en la cadena de valor para mejorar el desempeño de cada una de las áreas en sus respectivas actividades.

Tabla 19

Indicadores de las Actividades Primarias y de Apoyo

\begin{tabular}{|c|c|c|}
\hline Proceso & Indicador & Descripción \\
\hline \multicolumn{3}{|c|}{ Actividades primarias } \\
\hline \multirow{3}{*}{$\begin{array}{l}\text { Logística } \\
\text { entrada): }\end{array}$} & Cantidad de piezas de plata & Contar y validar el estado de las piezas de plata \\
\hline & $\begin{array}{l}\text { Cantidad de gemas y piedras } \\
\text { nativas }\end{array}$ & $\begin{array}{l}\text { Contar las gemas y piedras nativas y validar la } \\
\text { calidad de las piezas. }\end{array}$ \\
\hline & Cantidad de cajas para empaque & $\begin{array}{l}\text { Medir el desempeño del proveedor (calidad y } \\
\text { servicio el producto) }\end{array}$ \\
\hline \multirow[t]{2}{*}{ Operaciones } & $\mathrm{N}^{\circ}$ de cuños diseñados & Medir el cumplimiento y calidad del cuñero. \\
\hline & $\mathrm{N}^{\circ}$ de piezas producidas & $\begin{array}{l}\text { Contar el número de piezas ingresadas para } \\
\text { actualizar el stock }\end{array}$ \\
\hline \multirow[t]{2}{*}{ Logística exterior (de salida) } & Cantidad de pedidos entregados & Verificar la cantidad de piezas entregadas \\
\hline & Cantidad de piezas empaquetadas & Verificar la calidad y estado de la pieza entregada \\
\hline \multirow[t]{5}{*}{ Mercadotecnia y ventas: } & Cantidad de visitantes al fanpage & Contar número de visitantes al fanpage \\
\hline & Cantidad de fans & $\begin{array}{l}\text { Contar número de fans en la página para } \\
\text { determinar su nivel de atractividad }\end{array}$ \\
\hline & Ingreso de ventas por el fanpage & Contar y registrar número de ventas por fanpage \\
\hline & $\begin{array}{l}\text { Cantidad de asistentes al punto de } \\
\text { venta }\end{array}$ & $\begin{array}{l}\text { Contar y registrar número de asistentes a los } \\
\text { puntos de venta }\end{array}$ \\
\hline & Ingreso por ventas en las ferias & Contar número de piezas y monto vendido \\
\hline \multirow[t]{3}{*}{ Servicios de post venta } & Cantidad de piezas reparadas & $\begin{array}{l}\text { Contar número de piezas reparadas y el costo que } \\
\text { se incurre. }\end{array}$ \\
\hline & Cantidad de reclamos registrados & $\begin{array}{l}\text { Contar número de reclamos registrados y la razón } \\
\text { del mismo }\end{array}$ \\
\hline & Cantidad de reclamos resueltos & Medir el desempeño ante el reclamo \\
\hline \multicolumn{3}{|c|}{ Actividades de Apoyo } \\
\hline \multirow[t]{2}{*}{ Aprovisionamiento } & $\begin{array}{l}\text { Cantidad de proveedores } \\
\text { registrados }\end{array}$ & $\begin{array}{l}\text { Saber cuántos y cuáles son los proveedores con } \\
\text { los que se cuenta. }\end{array}$ \\
\hline & Monto por compra de insumo & Determinar los costos de compra de insumo. \\
\hline \multirow[t]{2}{*}{ Desarrollo de la tecnología } & $\begin{array}{l}\text { Gastos por suscripción a páginas de } \\
\text { publicidad }\end{array}$ & Determinar los gastos en publicidad \\
\hline & Gastos POS & Determinar los gastos por servicios de internet \\
\hline $\begin{array}{l}\text { Administración de recursos } \\
\text { humanos }\end{array}$ & Cantidad de trabajadores & $\begin{array}{l}\text { Determinar gasto de planilla y montos por } \\
\text { servicios a terceros. }\end{array}$ \\
\hline $\begin{array}{l}\text { Infraestructura de la } \\
\text { empresa }\end{array}$ & Monto de alquiler y mantenimiento & $\begin{array}{l}\text { Determinar los gastos mensuales de } \\
\text { administración y mantenimiento. }\end{array}$ \\
\hline
\end{tabular}

Nota. Tomado de Conceptos de Administración Estratégica (p. 120), por F. David, 2013, México, D.F., México: Prentice Hall. Copyrigth 2000 por Pearson Education.

\subsection{Benchmarking y Comparación con los Líderes de la Industria de Cada Una de las} Actividades de la Cadena de Valor

En 2015, DÁlessio definió “El benchmarking es un proceso sistemático y continuo para evaluar los productos, servicios y procesos de trabajos de las organizaciones que son reconocidas como representantes de las mejores prácticas, con el propósito de realizar mejoras organizacionales". El autor señaló que existen tres tipos de benchmarking:

- Interno: Actividades similares en diferentes áreas, departamentos, países, etc.

- Competitivo: Competidores que venden a la misma base de clientes. 
- Funcional o Genérico: Organizaciones avanzadas por tener lo más avanzado en productos/servicios y procesos

Para realizar el análisis benchmarking se analizó los datos otorgados por un experto de la industria (ver Apéndice A5) y el personal interno de la empresa (ver Apéndice A1), comparándolos con dos empresas del mismo rubro y similar tamaño de empresa (ver Apéndices A6, A7). Se ha considerado solo aquellos factores críticos de éxitos del MPC en los que Incas Jewelry SAC debería copiar para mejorar su competitividad en la industria de la joyería. Se realizó el benchmarking del tipo competitivo. Para ello se procede a analizar los factores claves de cada una de las actividades de la cadena de valor en el cual Incas Jewelry SAC debería mejorar y la competencia lleva la delantera (ver Tabla 20):

- Publicidad (Actividad Mercadotecnia y Ventas): En el MCP Incas Jewelry SAC obtuvo un puntaje de .06 de 1.00 , mientras que Joyas M\&F obtuvo 0.18 de $1.00 \mathrm{y}$ Spondylus obtuvo.24 de 1.00, en la tabla adjunta de muestra el versus de lo que hace la empresa y que hace la competencia que los hace mejores.

- Competitividad de precios (Actividad Mercadotecnia y Ventas): En el MCP Incas Jewelry SAC obtuvo un puntaje de .07 de 1.00, mientras que Joyas M\&F obtuvo. 21 de 1.00 y Spondylus obtuvo .28 de 1.00, en la tabla adjunta de muestra el versus de lo que hace la empresa y que hace la competencia que lo hace mejor.

- Reconocimiento de marca (Actividad Mercadotecnia y Ventas): En el MCP Incas Jewelry SAC obtuvo un puntaje de .12 de 1.00, mientras que Joyas M\&F obtuvo .12 de 1.00 y Spondylus obtuvo. 24 de 1.00, en la tabla adjunta de muestra el versus de lo que hace la empresa y que hace la competencia que los hace mejores.

- Variedad de productos (Actividad Operaciones): En el MCP Incas Jewelry SAC obtuvo un puntaje de .18 de 1.00, mientras que Joyas M\&F y Spondylus obtuvieron .24 de 1.00, en la tabla adjunta de muestra el versus de lo que hace la empresa y que hace la competencia que los hace mejores.

- Capacidad de producción (Actividad Operaciones): En el MCP Incas Jewelry SAC obtuvo un puntaje de .14 de 1.00, mientras que Joyas M\&F y Spondylus obtuvieron .28 de 1.00, en la tabla adjunta de muestra el versus de lo que hace la empresa y que hace la competencia que los hace mejores.

- Comercio electrónico (Actividad Desarrollo de Tecnologia): En el MCP Incas Jewelry SAC obtuvo un puntaje de .07 de 1.00, mientras que Joyas M\&F obtuvo .07 de 1.00 y Spondylus obtuvo .28 de 1.00, en la tabla adjunta de muestra el versus de lo que hace la empresa y que hace la competencia que los hace mejores. 
Tabla 20

Benchmarking y Comparación con los Líderes de la Industria de las Actividades de la Cadena de Valor

\begin{tabular}{|c|c|c|c|}
\hline $\begin{array}{l}\text { Factores Claves de } \\
\text { Éxito y Actividades de } \\
\text { la Cadena de Valor }\end{array}$ & Actividades Incas Jewelry & Actividades M\&F & Actividades Spondylus \\
\hline $\begin{array}{l}\text { Publicidad } \\
\text { (Mercadotecnia y } \\
\text { Ventas) }\end{array}$ & $\begin{array}{l}\text { Impresión de folletería } \\
\text { Impresión de volantes } \\
\text { Lanzamiento de campañas a través de Facebook } \\
\text { Página web }\end{array}$ & Recomendaciones boca a boca & $\begin{array}{l}\text { Uso de banners en las galerías } \\
\text { Impresión de folletería y volantes } \\
\text { Página web } \\
\text { Publicidad en el extranjero como proveedor internacional }\end{array}$ \\
\hline $\begin{array}{l}\text { Competitividad de } \\
\text { precios (Mercadotecnia } \\
\text { y Ventas) }\end{array}$ & $\begin{array}{l}\text { En tienda tiene precios altos debido a que su local es } \\
\text { alquilado y el costo producción de joyas es alto }\end{array}$ & $\begin{array}{l}\text { Tiene taller y más dos locales, permitiéndole } \\
\text { bajar precios de sus productos } \\
\text { Trabaja al por mayor }\end{array}$ & $\begin{array}{l}\text { Su principal actividad actualmente es la exportación. Se } \\
\text { mantiene en Lima porque es una ventana para que lo vean } \\
\text { desde afuera en las ferias locales en las que participa }\end{array}$ \\
\hline $\begin{array}{l}\text { Reconocimiento de la } \\
\text { marca (Mercadotecnia y } \\
\text { Ventas) }\end{array}$ & Solo publicidad por Facebook pero poco trafico & No hace nada & $\begin{array}{l}\text { Página web con alto tráfico de visitantes. } \\
\text { Tienen un Community manager } \\
\text { Aparecen en todas las revistas de Cámara de Comercio y } \\
\text { otras }\end{array}$ \\
\hline $\begin{array}{l}\text { Variedad del producto } \\
\text { (Operaciones) }\end{array}$ & $\begin{array}{l}\text { Diseños a la medida } \\
\text { Joyas con piedras semipreciosas } \\
\text { Artesanías y telares con motivos incaicos } \\
\text { Venta de joyas con piedras preciosas como diamantes y } \\
\text { oro a pedido }\end{array}$ & $\begin{array}{l}\text { Rapidez en los tiempos de producción } \\
\text { Joyas con piedras artificiales como circones o } \\
\text { múranos que son más baratos } \\
\text { No vende artesanías } \\
\text { Cuenta con stock permanente de joyas de oro }\end{array}$ & $\begin{array}{l}\text { Cuenta con stock de todas sus piezas } \\
\text { El } 70 \% \text { son trabajos solo en plata y el } 30 \% \text { de spondylus, } \\
\text { muy cotizado por el cliente por sus colores } \\
\text { No vende artesanías } \\
\text { Cuenta con stock permanente de joyas de oro }\end{array}$ \\
\hline $\begin{array}{l}\text { Capacidad de } \\
\text { producción } \\
\text { (Operaciones) }\end{array}$ & $\begin{array}{l}\text { Diseños propios de joyas } \\
\text { Elaboración del pedido del cliente } \\
\text { Selección de productos } \\
\text { Orfebres contratados por horas }\end{array}$ & $\begin{array}{l}\text { Diseños propios de joyas } \\
\text { Taller propio } \\
\text { Varios orfebres trabajando para la empresa }\end{array}$ & $\begin{array}{l}\text { Diseños propios de joyas } \\
\text { Taller propio } \\
\text { Varios orfebres trabajando para la empresa }\end{array}$ \\
\hline $\begin{array}{l}\text { Comercio electrónico } \\
\text { (Desarrollo de } \\
\text { Tecnología) }\end{array}$ & $\begin{array}{l}\text { Uso del fanpage a nivel usuario } \\
\text { Uso de páginas de comercio electrónico a nivel de } \\
\text { usuario }\end{array}$ & $\begin{array}{l}\text { Cuenta con stock permanente de joyas de oro } \\
\text { No cuenta, usa whatsapp }\end{array}$ & $\begin{array}{l}\text { Cuenta con un community manager } \\
\text { Uso de páginas de comercio electrónico }\end{array}$ \\
\hline & $\begin{array}{l}\text { Herramientas web para el cobro de las ventas } \\
\text { Publicación de productos en la fanpage }\end{array}$ & $\begin{array}{l}\text { Ventas directas a través de su propia web } \\
\text { Cuenta con un community manager }\end{array}$ & $\begin{array}{l}\text { Ventas directas a través de su propia web } \\
\text { Cuenta con un community manager }\end{array}$ \\
\hline $\begin{array}{l}\text { Promociones } \\
\text { (Mercadotecnia y } \\
\text { Ventas) }\end{array}$ & $\begin{array}{l}\text { Lanzamiento de combos de productos } \\
\text { Descuentos en ventas por volumen }\end{array}$ & Descuentos en ventas al por mayor & Descuento en venta de juegos de joyas (collar y aretes) \\
\hline $\begin{array}{l}\text { Canales de distribución } \\
\text { (Operaciones) }\end{array}$ & $\begin{array}{l}\text { Entrega de productos comprados por la web en la } \\
\text { tienda (único local) }\end{array}$ & $\begin{array}{l}\text { Tiene personal propio para la distribución de } \\
\text { sus joyas } \\
\text { Entrega los productos en cualquiera de sus } \\
\text { locales }\end{array}$ & Entrega los productos en cualquiera de sus locales \\
\hline & $\begin{array}{l}\text { Venta de productos en consignación } \\
\text { No tiene taller, alquila }\end{array}$ & $\begin{array}{l}\text { Cuenta una gran fuerza de ventas } \\
\text { Cuenta con } 3 \text { taller en el mismo punto de venta }\end{array}$ & $\begin{array}{l}\text { Fuerza de ventas con comisiones altas } \\
\text { Cuenta con varios talleres en el mismo punto de venta }\end{array}$ \\
\hline
\end{tabular}

Nota. Tomado de Conceptos de Administración Estratégica (p. 216), por F. David, 2013, México, D.F., México: Prentice Hall. Copyrigth 2000 por Pearson Education. 
- Promociones (Actividad Mercadotecnia y Ventas): En el MCP Incas Jewelry SAC obtuvo un puntaje de .07 de 1.00 , mientras que Joyas M\&F y Spondylus obtuvieron .21 de 1.00, en la tabla adjunta de muestra el versus de lo que hace la empresa y que hace la competencia que los hace mejores.

- Canales de distribución (Actividad Operaciones): En el MCP Incas Jewelry SAC obtuvo un puntaje de .09 de 1.00, mientras que Joyas M\&F y Spondylus ambas competencias de la empresa obtuvieron .36 de 1.00, en la tabla adjunta de muestra el versus de lo que hace la empresa y que hace la competencia que los hace mejores.

\subsection{Determinar las Competencias de la Empresa}

La empresa Incas Jewelry SAC es una empresa familiar, en la cual el Gerente General y sus hijos son los empleados y dueños del negocio. El Gerente General desea que las competencias de la empresa generen ventaja competitiva en el mercado para poder mejorar la salida de sus productos con el fin de poder exportar en un corto plazo. Estas variables fueron analizadas por el Gerente General en una entrevista en profundidad (ver Apéndice A1) y por lo analizado, se procede a determinar las competencias de la empresa (ver Tabla 21)

Tabla 21

Competencias de la Empresa Incas Jewelry SAC

\begin{tabular}{|c|c|}
\hline Competencias & Descripción \\
\hline $\begin{array}{l}\text { Estilo (diseños } \\
\text { exclusivos) }\end{array}$ & $\begin{array}{l}\text { El cliente busca un estilo étnico que se aplica a las joyas, retablos, telares. Una } \\
\text { parte de los productos que la empresa ofrece un diseño con estilo propio. }\end{array}$ \\
\hline Confiabilidad & $\begin{array}{l}\text { La empresa utiliza insumos de la mejor calidad en todos sus productos, generando } \\
\text { confianza entre los clientes nacionales como extranjeros. }\end{array}$ \\
\hline Servicio postventa & $\begin{array}{l}\text { El cliente tiene siempre la confianza que cualquier inconveniente será atendido, al } \\
\text { momento no se ha registrado ningún reclamo que no se haya podido resolver. }\end{array}$ \\
\hline $\begin{array}{l}\text { Puntualidad en entrega } \\
\text { de productos }\end{array}$ & $\begin{array}{l}\text { La empresa se caracteriza por cumplir con los tiempos de entrega prometidos, } \\
\text { incluso se estipula en el contrato o proforma escrita. }\end{array}$ \\
\hline
\end{tabular}

Nota. Tomado de Conceptos de Administración Estratégica (p. 119), por F. David, 2013,

México, D.F., México: Prentice Hall. Copyrigth 2000 por Pearson Education.

\subsection{Identificación y Determinación de las Ventajas Competitivas de la Empresa}

Las ventajas competitivas de toda organización se deben a los recursos con los que cuentan y en el correcto uso que hacen de ellos, para este subcapítulo utilizaremos la matriz VRIO que fue desarrollado por el inglés Jay B. Barney, esta matriz permite evaluar qué recursos internos que proporcionan ventaja competitiva. VRIO es el acrónimo de Valor, Raro, Imitable y Organización. Este es un sistema de análisis que debería formar parte de la estrategia de todas las empresas, ya que permite a cualquier negocio conocer de qué puntos de ventaja competitiva dispone dentro del mercado en que opera. El Análisis VRIO se utiliza 
como marco para evaluar los recursos y capacidades de la empresa. Cada recurso es evaluado en cuatro factores: (a). Valioso: ¿Explotamos una oportunidad o minimizamos una amenaza gracias a este recurso?; (b). Raro: ¿Es ese valor Raro, distinto a los recursos que tienen nuestros competidores?; (c). Inimitable: ¿Es el recurso difícil de imitar? ¿Cuánto costaría a nuestro competidor el copiarlo o presentar un sustituto?; (d). Inmerso en la organización: ¿Estamos preparados, como organización, para explotar esos recursos al máximo? (Barney, 1991). Luego estos deberán ser analizados de acuerdo a la Tabla 22.

Tabla 22

Matriz VRIO

\begin{tabular}{cclc}
\hline & Recurso & & Organización \\
\cline { 1 - 2 } Valioso & Raro & $\begin{array}{l}\text { Difícil de } \\
\text { imitar }\end{array}$
\end{tabular}$\quad \begin{array}{ll}\text { alineada con recursos } \\
\end{array}$

\begin{tabular}{|c|c|c|c|c|}
\hline $\mathrm{x}$ & & & & Desventaja Competitiva \\
\hline$\sqrt{ }$ & $\mathrm{x}$ & & & Igualdad Competitiva \\
\hline$\sqrt{ }$ & $\sqrt{ }$ & $\mathrm{x}$ & & Ventaja Competitiva Temporal \\
\hline$\sqrt{ }$ & $\sqrt{ }$ & $\sqrt{ }$ & $\mathrm{x}$ & Ventaja Competitiva por Explotar \\
\hline$\sqrt{ }$ & $\sqrt{ }$ & $\sqrt{ }$ & $\sqrt{ }$ & Ventaja Competitiva Sostenible \\
\hline
\end{tabular}

Nota. Adaptado de "Activa Conocimiento," por J. B. Barney, 1991, Revista Lideres para el Futuro, -, p. 2. Copyright 1991 por Progreso Personal y Profesional en Gestión y Liderazgo.

Para ese análisis se ha considerado los factores claves de éxito hallados en la MPC (ver Tabla 17) se identificaron tres recursos que generan ventaja competitiva porque son las que obtuvieron la puntuación más alta en el MPC a diferencia de las empresas de la competencia, incluso se ha considerado el recurso Calidad de productos que tenía la misma puntuación que la competencia, es en este punto que los hace iguales (ver Tabla 23).

Tabla 23

Matriz VRIO de Incas Jewelry

\begin{tabular}{|c|c|c|c|c|c|}
\hline Recurso & Es valioso & Raro? & $\begin{array}{l}\text { Difícil de } \\
\text { imitar? }\end{array}$ & $\begin{array}{c}\text { Bien usado en la } \\
\text { organización? }\end{array}$ & Implicancia \\
\hline Estilo & $\mathrm{Si}$ & $\mathrm{Si}$ & No & $\mathrm{Si}$ & $\begin{array}{l}\text { Ventaja competitiva } \\
\text { sostenible }\end{array}$ \\
\hline Confiabilidad & $\mathrm{Si}$ & $\mathrm{Si}$ & $\mathrm{Si}$ & $\mathrm{Si}$ & $\begin{array}{l}\text { Ventaja competitiva } \\
\text { sostenible }\end{array}$ \\
\hline Servicio postventa & $\mathrm{Si}$ & $\mathrm{Si}$ & No & $\mathrm{Si}$ & $\begin{array}{l}\text { Ventaja competitiva } \\
\text { temporal }\end{array}$ \\
\hline $\begin{array}{l}\text { Puntualidad en } \\
\text { entrega de } \\
\text { producto }\end{array}$ & $\mathrm{Si}$ & No & No & No & Desventaja competitiva \\
\hline
\end{tabular}

Nota. Adaptado de "Activa Conocimiento," por J. B. Barney, 1991, Revista Lideres para el Futuro, -, p. 2. Copyright 1991 por Progreso Personal y Profesional en Gestión y Liderazgo. 
La empresa Incas Jewelry SAC aún se mantiene en niveles de rentabilidad mínimos que permite su operatividad, pero no genera mayores ganancias, esto de acuerdo a la información entregada por el Gerente General (ver Apéndice A1). Dentro de las ventajas competitivas identificadas en la comparación con las empresas Joyas M\&F y Spondylus son:

- Estilo, Estos factores son bien manejados por la empresa, pues ofrece y vende tendencia ofreciendo diseños étnicos únicos, pero que si una empresa desea hacerlo fácilmente lo puede copiar. De acuerdo con la matriz VRIO implica tener una ventaja competitiva temporal existiendo la posibilidad que la competencia acabará copiándola. Para mantener esta ventaja competitiva se recomienda a Incas Jewelry seguir perfeccionando la calidad de los productos y obtener certificaciones que lo acrediten hasta encontrar el recurso que no sea Imitable a largo plazo y siempre mostrando vanguardia en sus diseños

- Confiabilidad, los clientes que compran en la empresa buscan joyas que duren, que no se negreen o no se deterioren pues el nivel de aleación con la que se produce para obtener una joya de plata 950 es respetado desde la compra de insumos, diseño propuesto por la empresa o el cliente hasta la entrega de un producto de buena calidad. De acuerdo con la matriz VRIO implica tener una ventaja competitiva sostenible lo que significa que la competencia difícilmente se puede copiar, mantener un estatus de confiabilidad lo ofrece el cliente, pero lo percibe el cliente.

- Servicio postventa, factor importante, en este caso el servicio de postventa que la entrega de producto revisado antes de entregarlo, cumple con garantía de tienda, con solo mostrar la boleta de la misma, se entregan empaques de acuerdo a la medida del producto, bolsa con el logo de acuerdo a los colores de la tienda.

- Puntualidad, este factor es muy importante en todo negocio y en la industria joyera no es diferente, es importante cumplir con los plazos establecidos con el cliente durante el contrato se ejerce entre la empresa y el consumidor De acuerdo con la matriz VRIO implica tener una ventaja competitiva sostenible pues son pocas las empresas que cumplen con ser puntuales y ellos mismos lo admiten deduciendo que tienen trabajo o no controlan bien su sistema de pedidos.

\subsection{Matriz de Evaluación de los Factores Internos EFI}

En 2013, David señaló "Esta herramienta para la formulación de estrategias sintetiza y evalúa las fortalezas y debilidades más importantes encontradas en las áreas funcionales de una empresa y también constituye la base para identificar y evaluar las relaciones entre estas 
áreas" (p. 122). David señala que seleccionar entre 10 y 20 factores es lo ideal entre fortalezas y debilidades. Los autores presentan 15. La cantidad de factores no tiene efecto sobre el rango de puntuación ponderada total porque las ponderaciones siempre suman 1.0.

En la Tabla 24 se muestra la Matriz EFI, que son los factores internos de la empresa Incas Jewelry, determinados por personal interno, las mismas que fueron tomadas de las entrevistas en profundidad a los empleados de la empresa. Asimismo, el autor señalo "La cantidad de factores no tiene efecto sobre el rango de puntuación ponderada total porque las ponderaciones siempre suman 1.0”. Nuestra ponderación es 2.66 que indica que Incas Jewelry tiene buenas fortalezas y sus debilidades no son tan altas.

Tabla 24

Matriz EFI.

\begin{tabular}{|c|c|c|c|}
\hline Fortalezas & Peso & Valor & Ponderación \\
\hline F1. Insumos de buena calidad & 0.06 & 4 & 0.24 \\
\hline F2. Diseño de productos a la medida & 0.10 & 4 & 0.40 \\
\hline $\begin{array}{l}\text { F3. Cumplimiento de estándares de la } \\
\text { industria joyera }\end{array}$ & 0.04 & 3 & 0.12 \\
\hline F4. Alianzas con proveedores & 0.06 & 3 & 0.18 \\
\hline $\begin{array}{l}\text { F5. Disponibilidad de diversos medios de } \\
\text { pago }\end{array}$ & 0.08 & 4 & 0.32 \\
\hline F6. Empleados comprometidos & 0.08 & 4 & 0.32 \\
\hline F7. Mano de obra calificada & 0.10 & 3 & 0.30 \\
\hline $\begin{array}{l}\text { F8. Empresa constituida } \\
\text { Debilidades }\end{array}$ & 0.08 & 4 & 0.32 \\
\hline D1. Baja automatización de procesos & 0.06 & 1 & 0.06 \\
\hline D2. Altos costos de producción & 0.06 & 1 & 0.06 \\
\hline D3. Portafolio limitado de joyas & 0.05 & 1 & 0.05 \\
\hline $\begin{array}{l}\text { D4. Bajo aprovechamiento del comercio } \\
\text { electrónico }\end{array}$ & 0.05 & 1 & 0.05 \\
\hline $\begin{array}{l}\text { D5. Reducida participación en ferias del } \\
\text { rubro }\end{array}$ & 0.04 & 1 & 0.04 \\
\hline D6. Carencia de taller propio & 0.04 & 1 & 0.04 \\
\hline D7. Limitada capacidad financiera & 0.06 & 2 & 0.12 \\
\hline $\begin{array}{l}\text { D8. Dedicación de personal a tiempo } \\
\text { parcial }\end{array}$ & 0.04 & 1 & 0.04 \\
\hline
\end{tabular}

Nota. 1: Debilidad mayor; 2: Debilidad menor; 3 Fortaleza menor; 4: Fortaleza mayor; para indicar con cuánta eficacia la empresa responde a dicho factor. Y el Total es la multiplicación del peso por el valor. Adaptado de Conceptos de Administración Estratégica (p. 123), por F. David, 2013, México, D.F., México: Prentice Hall. Copyrigth 2000 por Pearson Education. 


\section{Capítulo VII: Formulación de los Objetivos y Diseño de las Estrategias}

Para este capítulo se formuló los objetivos considerando que se mantengan alineados a la misión y visión de la empresa Incas Jewelry SAC, teniendo en cuenta el análisis interno de la organización y el análisis externo de la industria. Para ello se modelaron los lienzos del Océano Azul para luego determinar el tipo de estrategias a aplicar en la empresa se desarrollan las matrices de formulación de estrategias, como: FODA, PEYEA, MIE, BCG, GE.

\subsection{Alcance y Planteamiento de los Objetivos Estratégicos}

En 2013, David señaló “Una empresa debe tratar de llevar a cabo estrategias que obtengan beneficios de sus fortalezas internas, aprovechar las oportunidades externas, mitigar las debilidades internas y evitar o aminorar el impacto de las amenazas externas. En este proceso radica la esencia de la dirección estratégica.” (p.217). Asimismo, en los subcapítulos siguientes se procede a presentar los objetivos estratégicos, especificados por el Gerente General de Incas Jewelry, el cual se proceden a definir de acuerdo a lo hallado en el MPC.

\subsubsection{Objetivos estratégicos.}

De acuerdo a la misión y visión de Incas Jewelry SAC y al análisis interno y externo se establecieron los siguientes objetivos estratégicos y se detallará su ejecución en el capítulo IX:

- Rentabilidad:

- Hacer la empresa rentable al 2022.

- Lograr que un $15 \%$ de las ventas totales anuales al 2022 sean al exterior.

- Aumentar en 15\% los canales de atención al 2022.

- Control de costos y gastos:

- Reducir un 15\% los costos en compras a proveedores al 2022.

- Marketing Digital y Comercio Electrónico:

- Mejorar la experiencia de compra en un 85\% al 2022.

- Lograr que un $20 \%$ de las ventas totales anuales al 2022 sean por medios digitales.

- Fortalecimiento institucional

- Lograr que el 100\% del personal haya recibido una capacitación al 2022

\subsubsection{Análisis de los objetivos estratégicos.}

En 2015, D’Alessio señaló “Los objetivos estratégicos representan los resultados que la organización espera alcanzar luego de implementar las estrategias externas especificas 
escogidas, las cuales conducen hacia la visión establecida, dependerán de la industria, organización, sus productos y sus respectivos ciclos de vida”. Para un mejor entendimiento de los objetivos estratégicos se procede a definir tres enfoques, sugeridos por el Gerente General de la empresa.

- Rentabilidad: Comprende los objetivos estratégicos cuyas acciones están orientadas a aumentar la utilidad neta del negocio y exportar una parte de la producción de la empresa al 2022

- Control de costos y gastos: Comprende los objetivos estratégicos cuyas acciones están orientadas a reducir costos y gastos al 2022

- Marketing Digital y comercio electrónico: Comprende los objetivos estratégicos cuyas acciones están orientadas a la implementación de una plataforma ecommerce que permita generar ventas de nuevos clientes por medio de medios virtuales.

- Fortalecimiento institucional: Comprende el objetivo estratégico cuya acción primordial es capacitar a las unidades de negocio existentes con la finalidad de que ejerzan sus funciones de manera adecuada.

\subsection{Diseño y Formulación de Estrategias}

En 2013, David combinó diferentes técnicas para formulación de estrategias y que pueden integrarse en un modelo de toma de decisiones, tal como se muestra en la Figura 7 y que luego se procede a detallar

\begin{tabular}{|c|c|c|c|c|}
\hline \multicolumn{5}{|c|}{ Etapa 1: Etapa de los Insumos } \\
\hline \multirow[t]{2}{*}{$\begin{array}{c}\text { Matriz de } \\
\text { evaluación de los } \\
\text { factores externos } \\
\text { (EFE) }\end{array}$} & \multicolumn{3}{|c|}{$\begin{array}{c}\text { Matriz de perfil } \\
\text { competitivo (MPC) }\end{array}$} & $\begin{array}{c}\text { Matriz de } \\
\text { evaluación de los } \\
\text { factores internos } \\
(\mathrm{EFI})\end{array}$ \\
\hline & \multicolumn{3}{|c|}{ Etapa 2: Etapa de Adecuación } & \\
\hline \multirow[t]{2}{*}{$\begin{array}{c}\text { Matriz de } \\
\text { fortalezas, } \\
\text { oportunidades, } \\
\text { debilidades y } \\
\text { amenazas (FODA) }\end{array}$} & $\begin{array}{l}\text { Matriz de posición } \\
\text { estratégica y } \\
\text { evaluación de la } \\
\text { acción (PEYEA) }\end{array}$ & $\begin{array}{c}\text { Matriz de Boston } \\
\text { Consulting Group } \\
\text { (BCG) }\end{array}$ & $\begin{array}{l}\text { Matriz interna - } \\
\text { externa (IE) }\end{array}$ & $\begin{array}{c}\text { Matriz de la } \\
\text { estrategia principal }\end{array}$ \\
\hline & Matriz cuantitat & $\begin{array}{l}\text { a 3: Etapa de Deci } \\
\text { de la planificación }\end{array}$ & tégica (MCPE) & \\
\hline
\end{tabular}

Figura 7. Modelo Analítico para la Formación de la Estrategia. Tomado de Conceptos de Administración Estratégica (p. 174), por F. David, 2013, México, D.F., México: Prentice Hall. Copyright 2013 por Pearson Education

- Fase 1: Etapa de los Insumos. Es la fase de entrada donde se analizan las siguientes herramientas como: La Matriz de Evaluación de Factores Externos 
(EFE), analizada en el capítulo IV; La Matriz de Atractividad (MPC) y la Matriz de Evaluación de Factores Internos (EFI) en el capítulo VI.

- Fase 2: Etapa de Adecuación, denominada por el autor como fase de emparejamiento o del proceso estratégico, combina recursos y habilidades internas con las oportunidades y amenazas generadas por los factores externos, para ello se utilizan las siguientes matrices de formulación de estrategias, tales como: Matriz de Fortalezas, Oportunidades, Debilidades y Amenazas (FODA), Matriz de Posición Estratégica y Evaluación de la Acción (PEYEA), Matriz de Boston Consulting Group (BCG), Matriz Interna Externa (IE) y la Matriz de la Estrategia principal (Matriz de la Gran Estrategia) se proceden a analizar en este capítulo.

- Fase 3: Etapa de Decisión o de salida, usa la información de la fase 1, se evalúan las estrategias generadas en la fase 2 y se procede a seleccionar las más atractivas de la Matriz Interna y Externa que servirán para llevar a la organización al futuro deseado.

En 2013, David señaló “Las estrategias permiten que las organizaciones obtengan una ventaja competitiva a partir de tres ejes fundamentales: liderazgo en costos, diferenciación y enfoque. Porter llama a estos ejes estrategias genéricas.” (p.148). Incas Jewelry SAC debido a las ventajas competitivas como estilo, diseño propio, confiabilidad en el material, servicio de postventa orecido y puntualidad en la entrega de productos aplicará la estrategia genérica Diferenciación de productos cuya finalidad definida por el autor es producir bienes y servicios considerados únicos en toda la industria, y dirigirlos a consumidores que son relativamente insensibles al precio.

\subsubsection{Modelo Océano Azul.}

La estrategia del océano azul fue formulada por Chan y Mauborgne (2004) en un libro del mismo nombre ("Blue Ocean Strategy"), en el que defienden la importancia de la innovación a la hora de abrir nuevos mercados, alejándonos de la competencia destructiva que existe en los terrenos empresariales más explotados.

\subsubsection{Lienzo de la Estrategia Actual de la Empresa.}

En este sentido, Chan y Mauborgne (2004) establecieron como se captura el estado actual de la empresa y en que invierte. Para este caso se procede a analizar los factores claves de éxito identificados por la empresa Incas Jewelry SAC, se tomaron los datos validados por el Gerente General y las demás gerencias. Para realizar el cuadro estratégico de la empresa se siguieron los siguientes pasos, sugeridos por los autores del libro. 
El autor indicó: Valorar a cada empresa (competidor) en una escala de 1 a 10 sobre cada variable competitiva, sabiendo que 1 es la valoración mínima y 10 la valoración máxima. Se elabora el lienzo de la estrategia actual de la empresa (ver Figura 8) con los datos de las variables del sector tomadas del MPC (ver Tabla 17), las cuales fueron valoradas en la tabla 25. Para ello se explica la representación de los ejes: El eje horizontal refleja la gama de variables en las cuales invierte la industria y alrededor de las cuales gira la competencia. El eje vertical captura el nivel de oferta que los compradores reciben a lo largo de todos los factores considerados como clave. Actualmente existen muchas empresas en la industria de la joyería, fundamentadas en capítulos anteriores, en este subcapítulo se procede a detallar lo que hace Incas Jewelry y establecer los objetivos de acuerdo a las variables señaladas.

Tabla 25

Variables del Sector

\begin{tabular}{lc}
\hline \multicolumn{1}{c}{ Variables } & $\begin{array}{c}\text { Valoración } \\
\text { Incas Jewelry }\end{array}$ \\
\hline Publicidad & 1 \\
Calidad de productos & 9 \\
Estilo & 9 \\
Competitividad de precios & 4 \\
Reconocimiento de marca & 2 \\
Lealtad del cliente & 3 \\
Variedad de productos & 4 \\
Confiabilidad & 10 \\
Capacidad de producción & 2 \\
Comercio electrónico & 1 \\
Servicio postventa & 9 \\
Promociones & 2 \\
Canales de distribución & 1 \\
Puntualidad & 10 \\
\hline
\end{tabular}

Nota. Adaptado de La Estrategia del Océano Azul (p. 271), por W. Chan y R. Mauborgne, 2005,

Bogotá, Colombia: Norma 2005 por Harvard Business School Publishing Corporation. 
INCAS JEWELRY SAC

ALTO

BAJO
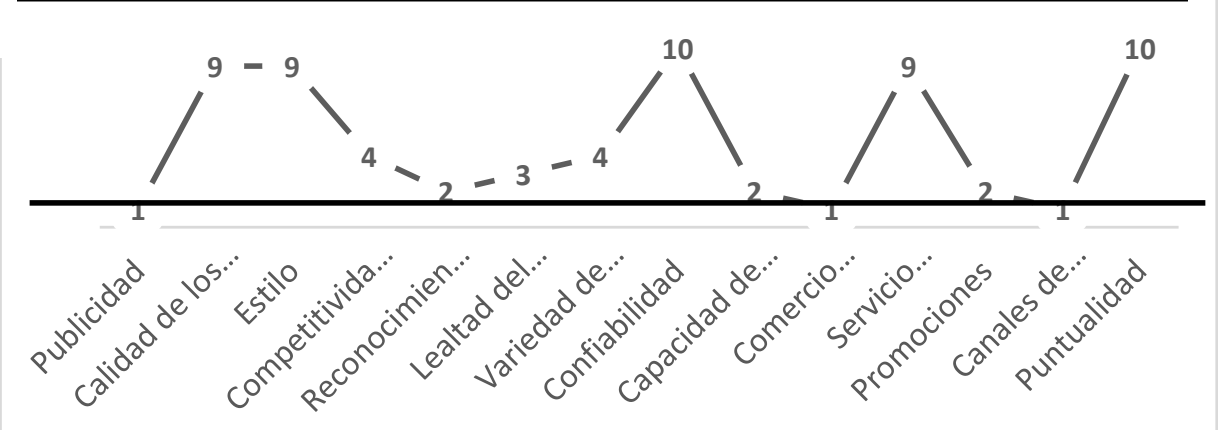

Figura 8. Lienzo de la Estrategia de la Empresa Incas Jewelry S.A.C. Adaptado de La Estrategia del Océano Azul (p. 216), por W. Chan y R. Mauborgne, 2005, Bogotá, Colombia: Norma 2005. Copyright 2013 por Harvard School Publishing Corporation.

Si bien es cierto la empresa mantiene puntuaciones altas en estilo, confiabilidad, puntualidad y servicio postventa, algunas son variables que bien pueden ser copiadas sin dificultad por la competencia por ello es necesario establecer estrategias que permitan diferenciar a la empresa de la competencia y así generar rentabilidad. Para la elaboración del lienzo, se han establecido siete variables que resumen las características más relevantes del sector y que afectan también a la empresa, se procede a su descripción:

- Publicidad: La empresa no hace publicidad en los medios de comunicación como periódicos, radios revistas. Solo a través de su fanpage, no cuenta con un community manager.

- Calidad de los productos: Los insumos para la producción de las joyas de plata son de buena fuente y se cumple con los estándares internacionales de aleación de plata 950, cuya composición es de $95 \%$ de plata y un 5\% de cobre mientras que la joya de Plata 925, tiene la composición es de $92.5 \%$ de plata y un $7.5 \%$ de algún otro metal como el cobre.

- Estilo: La empresa ofrece productos con diseños a la medida del cliente, conservando la confidencialidad de sus diseños sin volver a reproducirlos para otro cliente, salvo que lo autorice. Vende tendencia.

- Competitividad de precios: A la empresa le es difícil competir en precios debido a que la mayoría de sus productos son realizados a la medida y al no contar con taller propio no se pueden bajar los precios finales al cliente

- Reconocimiento de marca: Al ser una empresa pequeña los pocos clientes que tiene son aquellos que van a la tienda y como la mayoría son de procedencia extranjera, rara vez discuten la marca. 
- Lealtad del cliente: A pesar de ser una tienda pequeña, la red de contactos que tiene le suelen comprar por un tema de amistad y porque confían en que la joya ofrecida mantiene la calidad que ellos desean. Por otro lado, no hay lealtad de los clientes ocasionales.

- Variedad del producto: La empresa cuenta con gran variedad de productos, pero el stock por unidades producidas es limitado.

- Confiabilidad: Hay dos puntos aquí, la tienda está bien equipada en cuanto a los muebles y se entrega siempre boleta o factura y el trato de la vendedora que viene a ser la Gerente de Tienda y socia de la empresa conoce las bondades y características de cada uno de los productos garantizando la confiabilidad de lo que ofrece. Por otro lado, los clientes que regresan manifiestan que su joya es durable y no tiene deterioro como otras que compraron en otros lados.

- Capacidad de producción: Al no contar con taller propio y no tener mucha liquidez, limita la capacidad de producción

- Comercio Electrónico: Al no contar con un área de marketing, el personal que administra el comercio electrónico lo hace a manera de usuario y no profesional.

- Servicio postventa: Cuenta con asistencia de pre y post venta el cual es informado siempre al consumidor.

- Promociones: La empresa no tiene la suficiente liquidez para ofrecer grandes promociones, usualmente castiga su margen de utilidades para poder ganar un cliente.

- Canales de distribución: Solo vende en tienda, no tiene otros locales, ni deja productos en consignación a otros establecimientos.

- Puntualidad: La empresa de caracteriza por cumplir siempre con los plazos de entrega, son muy respetuosos con sus fechas estipulados en sus contratos.

\subsubsection{Lienzo de la Estrategia de la Industria.}

Estas empresas son más grandes que la empresa en estudio, pero son las que pudieron proporcionar información. Para realizar el cuadro estratégico de la industria se siguieron los siguientes pasos, sugeridos por los autores del libro (Chan W. \& Mauborgne, 1994):

1. Se identificó a la competencia, en este caso: Joyas M\&F y Spondylus.

2. Se identificó las variables competitivas del sector sugeridas por el autor.

3. El autor indica: Valorar a cada empresa (competidor) en una escala de 1 a 10 sobre cada variable competitiva, sabiendo que 1 es la valoración mínima y 10 la valoración máxima. 
Con los datos mencionados se elabora el lienzo de la estrategia de la industria. Para ello se explica la representación de los ejes: El eje horizontal refleja la gama de variables en las cuales invierte la industria y alrededor de las cuales gira la competencia. El eje vertical captura el nivel de oferta que los compradores reciben a lo largo de todos los factores considerados como clave. Para la elaboración del lienzo, se han establecido siete variables que resumen las características más relevantes del sector y que afectan también a la empresa, se procede a su descripción (ver Tabla 26).

- Publicidad: La industria de la joyería invierte mucha publicidad, es común ver en los programas de televisión indicar de donde son los accesorios de los

Tabla 26

Variables Competitivas del Sector

\begin{tabular}{|c|c|c|c|c|}
\hline \multirow[b]{2}{*}{ Variables } & \multicolumn{3}{|c|}{ Valoración } & \multirow[b]{2}{*}{ Promedio } \\
\hline & $\begin{array}{l}\text { Incas } \\
\text { jewelry }\end{array}$ & $\begin{array}{c}\text { Joyas } \\
\text { m\&f }\end{array}$ & Spondylus & \\
\hline Publicidad & 1 & 4 & 10 & 5 \\
\hline Calidad de productos & 9 & 7 & 10 & 9 \\
\hline Estilo & 9 & 7 & 8 & 8 \\
\hline Competitividad de precios & 4 & 9 & 7 & 7 \\
\hline Reconocimiento de marca & 2 & 6 & 9 & 6 \\
\hline Lealtad del cliente & 3 & 5 & 7 & 5 \\
\hline Variedad de productos & 4 & 7 & 9 & 7 \\
\hline Confiabilidad & 10 & 8 & 5 & 8 \\
\hline Capacidad de producción & 2 & 8 & 10 & 7 \\
\hline Comercio electrónico & 1 & 5 & 5 & 4 \\
\hline Servicio al cliente & 9 & 5 & 6 & 7 \\
\hline Promociones & 2 & 7 & 9 & 6 \\
\hline Canales de distribución & 1 & 9 & 9 & 6 \\
\hline Puntualidad & 10 & 8 & 5 & 8 \\
\hline
\end{tabular}

Nota. Adaptado de La Estrategia del Océano Azul (p. 65), por W. Chan y R. Mauborgne, 2005, Bogotá, Colombia: Norma 2005 por Harvard Business School Publishing Corporation.

comunicadores. Si la empresa no genera mucha publicidad es casi imposible generar ventas. Existen en la fecha algunas aplicaciones gratuitas y si se tiene una community manager es más fácil controlar esta variable.

- Calidad de los productos: Existen dudas sobre los insumos para la producción de las joyas de plata en el sector joyero, pues no todos utilizan la correcta proporción de metales en la aleación para crear la joya.

- Estilo: Cada empresa en la industria de la joyería se crea su propio estilo ya sea en la producción única de piezas, empaque, promociones o vigencia limitada de productos. 
- Competitividad de precios: El sector joyero manejan sus precios dependiendo de la demanda, precio de la materia prima de la plata, diseño de la joya, su producción utilizando tecnología o artesanal, el tener un artesano trabajando en su taller en todo momento, tener varios locales incluso en la misma galería hace que exista competitividad de precios. Otro punto importante es los que tienen suficiente solidez financiera pueden jugar con sus márgenes de ganancia, lo cual impacta en el precio final ofrecido al cliente.

- Reconocimiento de marca: Son pocas las marcas reconocidas a nivel pymes, esto se debe a la poca difusión del arte en plata en Perú, es por ellos que muchas empresas exportan sus productos o son canales de distribución vendiendo por grandes volúmenes a grandes joyerías que venden, pero no producen.

- Lealtad de cliente: Esta variable es relativa y tiene que ver con la calidad del producto servicio postventa y precio.

- Variedad del producto: Esta variable en el sector joyero va a depender de la liquidez de la empresa, pues es importante tener dinero para producir muchas joyas o variedad de joyas

- Confiabilidad: Existe mucha estafa en la industria de la joyería pues existen pocos clientes reconocedores de estas piezas, la confiabilidad va ligado al nombre de la empresa y si es pyme dependerá de la persona quien te venda y que con el tiempo no manifiesta problemas en su compra generando credibilidad, pero a largo plazo.

- Capacidad de producción: Esta variable en el sector dependerá de tres factores, una es liquidez, la otra es contar siempre con personal que se encargue de la producción de las joyas y por ultimo contar con un taller que cuenta con las herramientas mínimas para la elaboración de joyas.

- Comercio Electrónico: Las empresas muy independientes de que tan grande estas sean, todas manejan el comercio electrónico, por ser una tendencia usada por todas las personas hoy en día, generando de esta manera una oportunidad para ofrecer cualquier tipo de producto.

- Servicio postventa: En el sector de la joyería esta variable no es ajena, todas las empresas que venden productos tienen servicio al cliente, algunas pueden ser extraordinarias desde la preventa hasta la postventa, como también otras empresas no son buenas porque sus vendedoras no conocen bien sus productos o los productos no son de calidad y antes los reclamos no quieren atenderlos. 
- Promociones: Para que una empresa ofrezca promociones debe tener mucha liquidez que le permita jugar con sus márgenes de ganancia, aunque existen promociones en las cuales se pueden castigar estos márgenes con la esperanza de atraer más clientes y poder ganar por volumen de venta.

- Canales de distribución: Las joyerías son un sector cuyo producto de venta no es de primera necesidad, por lo que su venta no es tan rápida en el sector. Por ello la mayoría de ellos tienen varios locales incluso cercanos entre ellos y también distribuyen a otras empresas que se dedican a la venta de este bien.

- Puntualidad: Como en toda empresa la puntualidad no es una característica de los vendedores, hacen una estimación inexacta de la entrega del producto, algunas veces es por presión del cliente, por temor a la competencia o simplemente no manejan sus procesos de producción.

Con lo mencionado se procedió a elaborar el lienzo estratégico de la Empresa Incas Jewelry SAC, Joyas M\&F y Spondylus, caracterizado por las variables mencionadas (ver Figura 9)

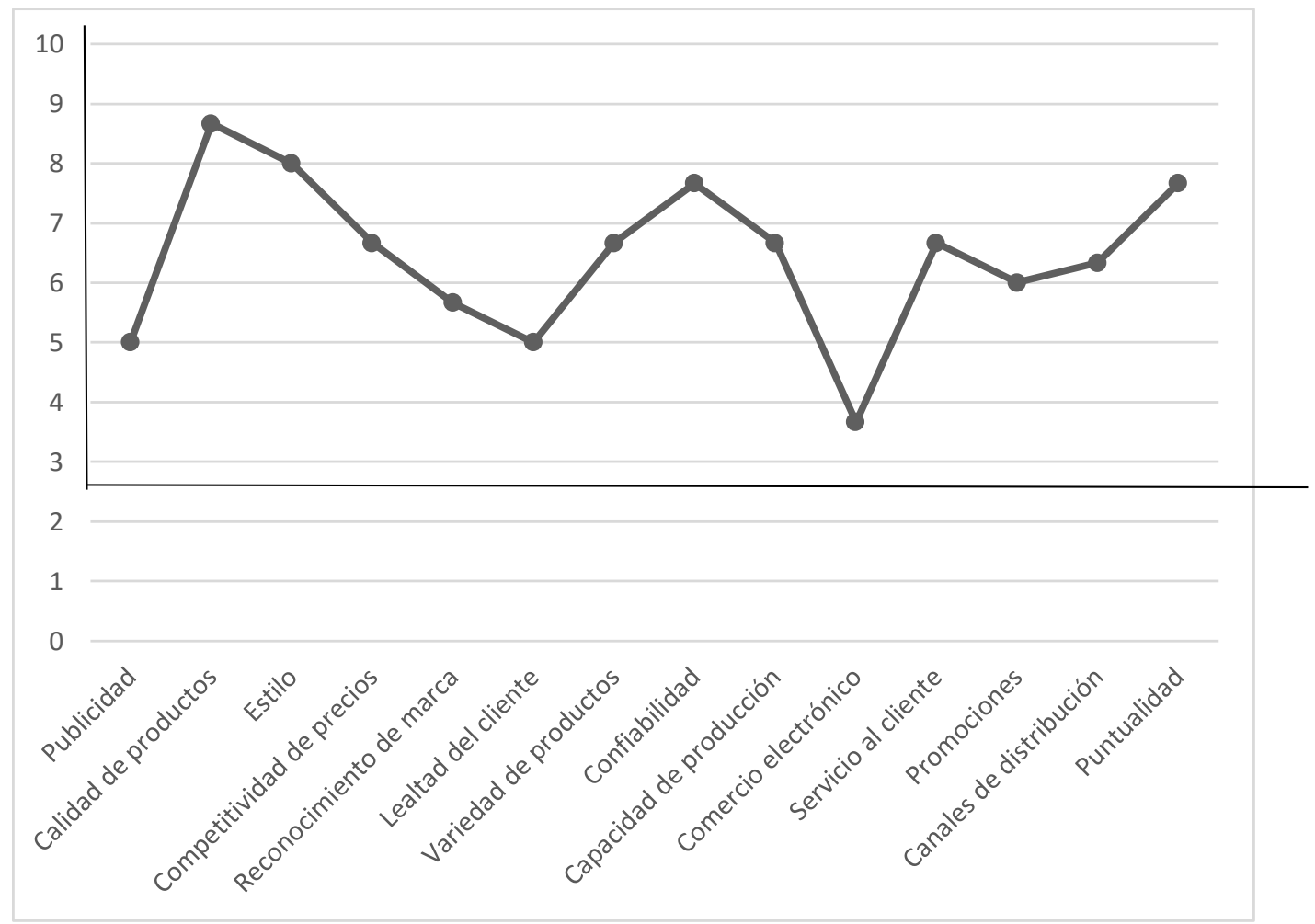

Figura 9. Lienzo de la Estrategia de la Industria. Adaptado de La Estrategia del Océano Azul (p. 216), por W. Chan y R. Mauborgne, 2005, Bogotá, Colombia: Norma 2005. Copyright 2013 por Harvard School Publishing Corporation. 


\subsubsection{Matriz Eliminar, Reducir, Incrementar, Crear.}

En este sentido, Chan y Mauborgne (2004) utilizaron el esquema de las cuatro acciones para establecer acciones orientadas la creación de una nueva curva de valor. Para el análisis del mismo se debe responder las preguntas sugeridas por el autor (ver Figura 10). Luego se procedió a realizar la matriz que permitió analizar la estrategia actual y definir qué factores deben de eliminarse, reducirse, incrementar o crear de ser necesarias. La intención es ofrecer productos de alto valor agregado diferenciándolo en estilo, calidad de productos, confiabilidad y puntualidad (ver Tabla 27).

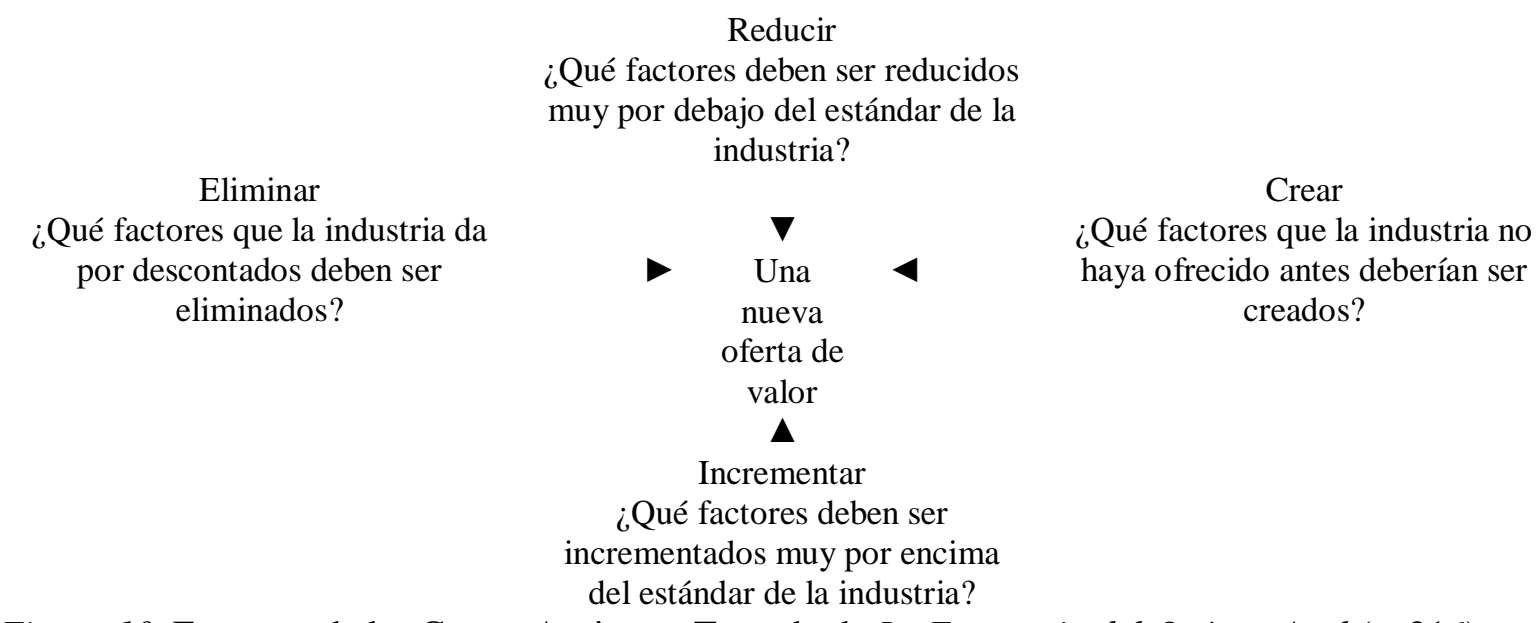

Figura 10. Esquema de las Cuatro Acciones. Tomado de La Estrategia del Océano Azul (p. 216), por W. Chan y R. Mauborgne, 2005, Bogotá, Colombia: Norma 2005. Copyright 2013 por Harvard School Publishing Corporation.

Tabla 27

Matriz Eliminar, Reducir, Incrementar y Crear

\begin{tabular}{cl}
\hline Eliminar X $\mathbf{X}$ & \multicolumn{1}{c}{ Incrementar $\Delta$} \\
\hline & Alianzas estratégicas con los \\
& proveedores \\
- & Capacitación a la fuerza de ventas
\end{tabular}

\begin{tabular}{llllll}
\hline \multicolumn{2}{c}{ Reducir $\boldsymbol{\nabla}$} & & \multicolumn{2}{c}{ Crear ? } \\
\hline $\begin{array}{l}\text { Compra de productos de baja } \\
\text { rentabilidad }\end{array}$ & & Implementación del marketing \\
& & digital. \\
& - & Estrategia comercial que permitan \\
& aumentar los ingresos \\
& $-\begin{array}{l}\text { Diversificación de productos } \\
\text { sustitutos }\end{array}$ & \\
& &
\end{tabular}

Nota. Adaptado de La Estrategia del Océano Azul (p. 65), por W. Chan y R. Mauborgne, 2005, Bogotá, Colombia: Norma 2005 por Harvard Business School Publishing Corporation.

Del análisis realizado, la nueva estrategia del océano azul para Incas Jewelry SAC, se enfocará en la calidad de los productos, produciendo joyas que mantengan los lineamientos 
de aleación de los metales para obtener joyas de plata 950. También en la variación de productos, ofreciendo mayor cantidad de productos incluso venta de productos sustitutos y reduciendo la compra de productos que representan baja rentabilidad. Se pretende asimismo repotenciar el servicio al cliente capacitando a la vendedora en técnicas de ventas.

- Eliminar: No se eliminará ningún factor de los actuales.

- Incrementar: Se incrementará el uso del comercio electrónico, alianzas estratégicas con los proveedores y capacitación a la fuerza de ventas.

- Reducir: Se reducirá la compra de productos para incrementar la rentabilidad para la empresa.

- Crear: Se creará estrategia comercial que permita aumentar los ingresos, crear la diversificación de los productos que permitan generar ingresos y se implementará el marketing digital.

\subsubsection{Lienzo de la Nueva Estrategia Considerada.}

Respondiendo a hallado en la Matriz "Eliminar, reducir, incrementar y crear, se procede a colocar las variables que podrían ayudar a cumplir las estrategias planteadas. Para la preparación de este lienzo se analizó las variables de la matriz del subcapítulo anterior para ver el estado actual de Incas Jewelry SAC con respecto a su competencia (ver Figura $11)$.

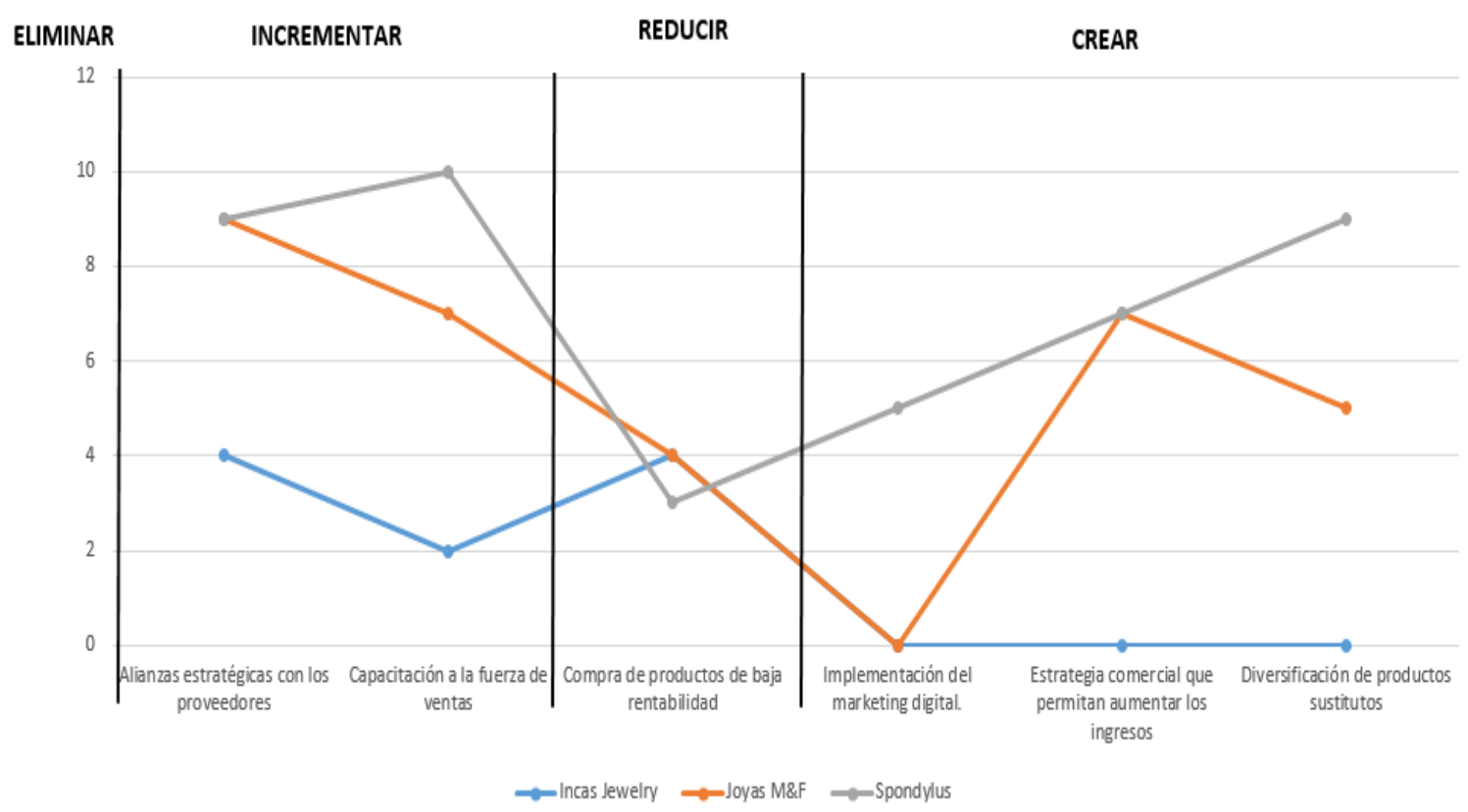

Figura 11. Cuadro Estratégico de los Competidores Principales. Adaptado de La Estrategia del Océano Azul (p. 216), por W. Chan y R. Mauborgne, 2005, Bogotá, Colombia: Norma 2005. Copyright 2013 por Harvard School Publishing Corporation. 
Del análisis de cuadro anterior se pudo determinar qué acciones se deben implementar. Para ello se calificaron las variables que generan tendencia en la matriz mencionada de 0 al 10, siendo 0 menor y 10 mayor oportunidad (ver Tabla 28).

Tabla 28

Variables Identificadas para el Cumplimiento del Objetivo Estratégico

\begin{tabular}{|c|c|c|c|c|}
\hline Factores de éxito & Eliminar & Incrementar & Reducir & Crear \\
\hline Alianzas estratégicas con los proveedores & 0 & 10 & & \\
\hline Capacitación a la fuerza de ventas & 0 & 5 & & \\
\hline Compra de productos de baja rentabilidad & 0 & & 5 & \\
\hline Implementación del marketing digital. & 0 & & & 8 \\
\hline Estrategia comercial que permitan aumentar los ingresos & 0 & & & 9 \\
\hline Diversificación de productos sustitutos & 0 & & & 8 \\
\hline
\end{tabular}

Nota. Adaptado de La Estrategia del Océano Azul (p. 65), por W. Chan y R. Mauborgne, 2005, Bogotá, Colombia: Norma 2005 por Harvard Business School Publishing Corporation.

Luego de ello se procedió a analizar cuál de ellas ayuda al cumplimiento de los objetivos estratégicos (ver Tabla 29). Para luego poder generar el Lienzo de la nueva estrategia considerada (ver Figura 12).

- Eliminar: No se aplica a eliminar ni colocar ninguna acción que interfiera en el cumplimiento de alguno de los objetivos.

- Incrementar: Si se logra incrementar el uso del comercio electrónico, ayudará a cumplir el objetivo "Implementar el comercio electrónico", pues actualmente la empresa no utiliza de manera eficiente este indicador; Promover más alianzas estratégicas con los proveedores permitirá optimizar costos, actualmente la empresa tiene proveedores de confianza a quienes les compra pero no existe ningún tipo de alianza con ellos que permita optimizar la llegadas de los productos o insumos a la tienda en los tiempos pactados; Capacitar a la fuerza de ventas permitirá incrementar los ingresos de la empresa por ventas y así poder liberar la manera correcta de poder vender mediante técnicas de ventas.

- Reducir: Si se logra reducir la compra de productos que generan baja rentabilidad, permitirá cumplir con los objetivos "Incrementar la rentabilidad" ya que actualmente se compran productos sin análisis previo de cuanto se cuenta en caja o si son prescindibles o no y "Optimizar gastos" pues se dejará de comprar productos que no tiene mucha salida o son de venta lenta.

- Crear: Si se implementa el marketing digital, podrá mejorar la publicidad de la empresa; Si se genera una estrategia comercial para incrementar los ingresos se podrá captar nuevos clientes utilizando el comercio electrónico y controlar los 
procesos. Y la diversificación de nuevos productos sustitutos permitirá crear nuevos canales de distribución.

Tabla 29

Variables de la Matriz Eliminar, Reducir, Incrementar y Crear con Respecto a los Competidores

\begin{tabular}{lcccc}
\hline & Incas Jewelry & Joyas M\&F & Spondylus & Promedio \\
\hline Uso del comercio electrónico & 1 & 1 & 2 & 7 \\
Alianzas estratégicas con los proveedores & 4 & 9 & 9 & 6 \\
Capacitación a la fuerza de ventas & 2 & 7 & 10 & 4 \\
Compra de productos de baja rentabilidad & 4 & 4 & 3 & 2 \\
Implementación el marketing digital. & 0 & 0 & 5 & 5 \\
Estrategia comercial que permitan aumentar & 0 & 7 & 7 & 5 \\
los ingresos & & 5 & 9 & 7
\end{tabular}

Nota. Adaptado de La Estrategia del Océano Azul (p. 65), por W. Chan y R. Mauborgne, 2005, Bogotá, Colombia: Norma 2005 por Harvard Business School Publishing Corporation.

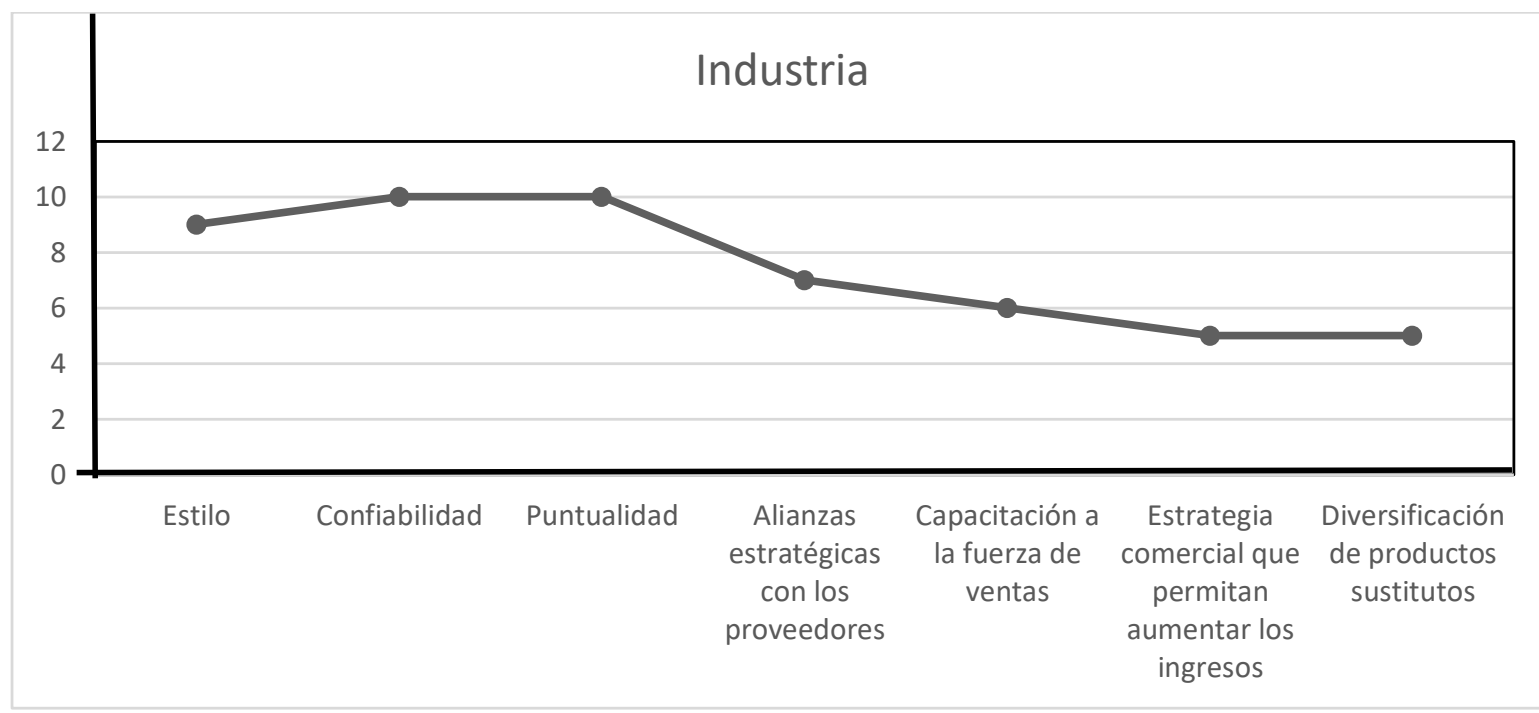

Figura 12. Lienzo de la Nueva Estrategia Considerada. Adaptado de La Estrategia del Océano Azul (p. 216), por W. Chan y R. Mauborgne, 2005, Bogotá, Colombia: Norma 2005. Copyright 2013 por Harvard School Publishing Corporation.

\subsubsection{Matrices de Formulación de Estrategias.}

En 2013, David seña ló “La identificación y evaluación de las estrategias alternativas debe involucrar a muchos de los directivos y empleados que formularon las declaraciones de la visión y la misión organizacionales, y también a aquellos que participaron en la realización de las auditorías externa e interna” (p.173). Por ello, para el desarrollo de este subcapítulo se realizaron entrevistas en profundidad al personal interno de la empresa (ver Apéndice A). En los siguientes puntos se procede a elaborar y analizar: La Matriz de Fortalezas, 
Oportunidades, Debilidades y Amenazas (FODA), la matriz de posición estratégica y evaluación de la acción (PEYEA), la matriz interna-externa (IE), la matriz del Boston Consulting Group (BCG, o matriz de crecimiento-participación) y la matriz de la Gran Estrategia.

\subsubsection{Matriz FODA.}

En 2013, David señaló "La matriz de fortalezas, oportunidades, debilidades y amenazas (FODA) es una importante herramienta de adecuación que ayuda a los directivos a desarrollar cuatro tipos de estrategias: estrategias FO (fortalezas-oportunidades), estrategias DO (debilidades-oportunidades), estrategias FA (fortalezas-amenazas) y estrategias DA (debilidades-amenazas)". Basados en la información del MEFE y MEFI detallados en capítulos 4.5 y 6.6 respectivamente se procede a elaborar la Matriz FODA, que nos permitirá elaborar los cuatro tipos de estrategias. Las estrategias FO, (Explotar). Generar estrategias utilizando las fortalezas internas de la organización que puedan sacar ventajas de las oportunidades externas. Las estrategias FA, (Confrontar). Generar estrategias usando las fortalezas de la organización para evitar o reducir el impacto de las amenazas externas. Las estrategias DO: (Buscar). Generar estrategias que buscan mejorar las debilidades internas para sacar ventajas de las oportunidades externas. Mientras que las estrategias DA: (Evitar) Genera las estrategias considerando acciones defensivas con el fin de reducir las debilidades internas evitando las amenazas del entorno. Del análisis obtenido del FODA, se procede a realizar el cruce de las mismas, según lo descrito en los párrafos anteriores (ver Tabla 30). Se procede a emparejar el FO, FA, DO y DA con la intención de presentar las estrategias.

Para elaborar la matriz FODA se analizaron las fortalezas, oportunidades, debilidades y amenazas extraídas de las entrevistas en profundidad a personal interno y expertos en la industria, como se explicó en capítulos anteriores para la elaboración de las matrices EFE y EFI. Luego se procedió a elaborar el cruce proponiendo estrategias que puedan ayudar a mejorar la viabilidad del proyecto.

\subsubsection{Matriz PEYEA.}

En 2015, D’Alessio mostró una explicación de esta matriz, que fuera elaborada por Dickel en 1984 con la finalidad de determinar a mejor postura estratégica de una organización o de sus unidades de negocio. Esta matriz consiste en tener dos ejes en los que se combinan los factores relativos a la industria, como Fortaleza de la Industria (FI) y la Estabilidad del Entorno (EE) mientras que los dos otros ejes combinan los factores relativos de la organización, como Fortaleza Financiera (FF) y Ventaja Competitiva (VC), formando un marco con cuatro cuadrantes, en el cual cada uno está asociado a una estratégica básica: 
Tabla 30

Matriz FODA

Fortalezas

1. Insumos de buena calidad

F2. Diseño de productos a la medida

F3. Cumplimiento de estándares de la industria joyera

Cruce FODA

F4. Alianzas con proveedores

F5. Disponibilidad de diversos medios de pago

F6. Empleados comprometidos

F7. Mano de obra calificada

F8. Empresa constituida

Debilidades

D1. Baja automatización de proceso

D2. Altos costos de producción

D3. Portafolio limitado de joyas

D4. Bajo aprovechamiento del comercio electrónico

D5. Reducida participación en ferias del rubro

D6. Carencia de taller propio

D7. Limitada capacidad financiera

D8. Dedicación de personal a tiempo parcial

\section{Oportunidades}

Estrategia - FO

Estrategia - DO

\section{O1. Existencia de TLC con países con alto}

potencial de compradores y proveedores

O2. Alta demanda de compradores de joyas de

plata

O3. Existencia de importadores de Europa y

Asia

O4. Alto poder adquisitivo de clientes

extranjeros

O5. Existencia de ferias

O6. Potencial de las redes sociales para

comercializar productos

O7. Posicionamiento de los diseños étnicos

peruanos a nivel mundial

Amenazas

A1. Presencia de mayoristas

A2. Existencia de productos sustitutos

A3. Economía de escala de las grandes tiendas

A4. Alza de precio de los insumos

A5. Limitado apoyo de la cámara de comercio

A6. Alta informalidad en el sector

A7. Presencia de grandes marcas

A8. Existencia de empresas virtuales

A9. Piratería de diseño
$\mathrm{F} 4: \mathrm{O} 1,5$

$\mathrm{F} 5,6,7 ; \mathrm{O} 2,3,5$

6

$\mathrm{F} 1,3,8 ; \mathrm{O} 5$

$\mathrm{F} 2,7 ; \mathrm{O} 2,4,7$

\section{Estrategia de penetración de mercado generando alianzas}

os proveedores.

Estrategia de penetración de mercado aumentando los

canales de distribución y medios digitales

Estrategia de desarrollo de producto buscando liderar e

mercado mediante certificaciones

Estrategia de penetración de mercado valorizando los modelos étnicos.
D3,6; O7 Estrategia de penetración de mercado con la

incorporación de nuevos diseños.

D1,3,4,5,7 Estrategia de penetración de mercado utilizando los $\mathrm{O} 2,3,4,6,7$ medios digitales.

D6; O1,5 Estrategia de penetración de mercado ajustando precios.

D4,06

Estrategia de penetración de mercado introduciendo productos en ferias locales.

D2,8,07 Estrategia de diversificación relacionada agregando productos nuevos relacionados con los presentes

\footnotetext{
Adaptado de Conceptos de Administración Estratégica (p. 177), por F. David, 2013, México, D.F., México: Prentice Hall. Copyrigth 2013 por

Pearson Education.
} 
Agresiva, conservadora defensiva o competitiva (ver Figura 13). Se procede a dividir las variables en dos posiciones estratégicas: Internas y Externas, tal como lo señala David (2013). Estas variables fueron calificadas junto con el personal interno de la empresa Incas Jewelry en una de las reuniones semanales que la empresa suele hacer (ver Tabla 31).

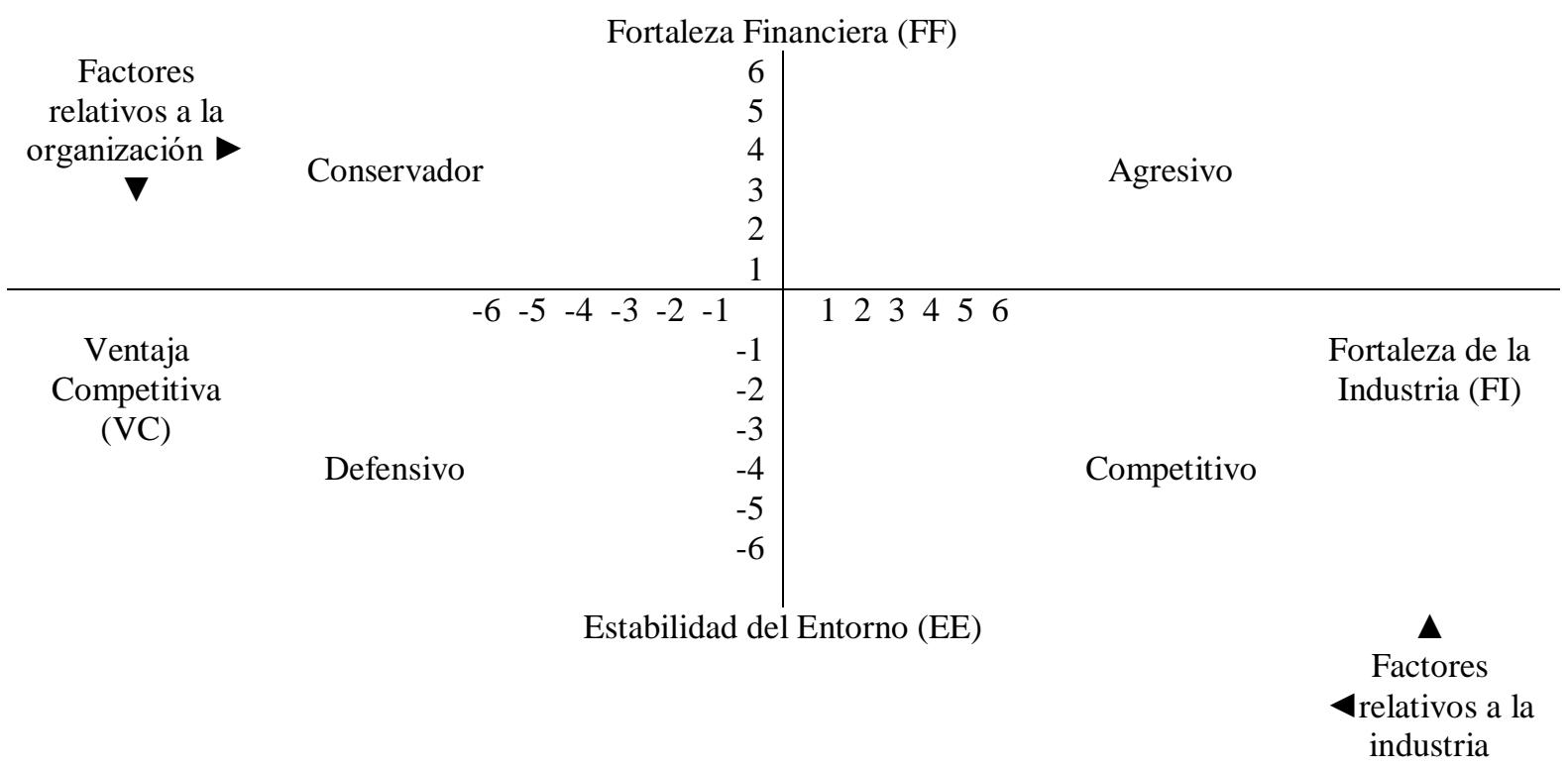

Figura 13. Matriz PEYEA. Tomado de Proceso Estratégico (p. 317), por F. D’Alessio, 2015, Lima, Perú: Pearson. Copyright 2015 por Pearson Education de Perú S.A.

\section{Posición Estratégica Interna.}

Complementando a lo que el autor indica, en esta posición se describe la fortaleza financiera y ventaja competitiva de la empresa:

- Fortaleza Financiera (FF): Refleja las condiciones económicas en las que se encuentra Incas Jewelry SAC, cuando tiene un poder de negociación porque tiene fortaleza financiera, para ello se determinaron los factores determinantes de la FF, calificadas del +1 (la peor) a +7 (la mejor) posición financiera. El promedio de FF para la empresa Incas Jewelry es de 4.88, en este punto se puede apreciar que las empresas de este rubro tienden a endeudarse en materia prima, productos con la finalidad de vender en volúmenes alto y para el caso de las pymes es más difícil por un tema de liquidez, pues temen endeudarse.

- Ventaja Competitiva (VC): Se determina las ventajas competitivas de Incas Jewelry SAC, calificando esta posición -1 (la mejor) a -7 (la peor) ventaja competitiva. El promedio de VC para la empresa Incas Jewelry es de -4.80 , sus mejores factores determinantes son calidad de productos porque busca la fiabilidad y garantía en la aleación de las joyas ofrecidas; Otra es variedad de 
Tabla 31

Factores que Constituyen las Variables de los Ejes de la Matriz PEYEA

\begin{tabular}{|c|c|c|c|c|c|}
\hline Posición estratégica interna & \multirow{2}{*}{\multicolumn{2}{|c|}{$\frac{\text { Calificación }}{1 \text { a } 7 \text { (peor - mejor) }}$}} & Posición estratégica externa & Calificación & \\
\hline Fuerza financiera (ff) & & & Estabilidad del entorno - (ee) & \multicolumn{2}{|c|}{-1 a -7 (mejor - peor) } \\
\hline Retorno de la inversión & \multicolumn{2}{|c|}{5} & Innovación y desarrollo & $-2-$ & \\
\hline Liquidez & \multicolumn{2}{|l|}{3} & Volumen del comprador & -1 & \\
\hline Facilidad para salir del negocio & \multicolumn{2}{|l|}{6} & Sensibilidad del comprador al precio & -3 & \\
\hline Nivel de endeudamiento /ventas & \multicolumn{2}{|l|}{7} & Existencia de barrera a la entrada & -7 & \\
\hline Capacidad de capitalización & \multicolumn{2}{|l|}{4} & Coste o facilidad de cambio del comprador & -1 & \\
\hline Capacidad de endeudamiento & \multirow{2}{*}{\multicolumn{2}{|c|}{$\begin{array}{l}4 \\
6\end{array}$}} & Presión relativos de los productos sustitutos & -5 & \\
\hline Riesgo del negocio & & & & & \\
\hline Rotación de inventarios & 4 & 4.88 & & & -3.17 \\
\hline Posición estratégica interna & \multicolumn{2}{|l|}{ Calificación } & Posición estratégica externa & \multicolumn{2}{|c|}{ Calificación } \\
\hline Ventaja competitiva - (vc) & \multicolumn{2}{|c|}{-1 a -7 (mejor - peor) } & Fortaleza industrial - (fi) & \multicolumn{2}{|c|}{1 a 7 (peor - mejor) } \\
\hline Publicidad & \multicolumn{2}{|c|}{$\begin{array}{l}-7 \\
-1\end{array}$} & Crecimiento industrial & \multicolumn{2}{|c|}{7} \\
\hline Calidad de productos & \multicolumn{2}{|l|}{-1} & $\begin{array}{l}\text { Coste de los productos del proveedor en relación con el coste } \\
\text { del producto final }\end{array}$ & 3 & \\
\hline Estilo & \multicolumn{2}{|l|}{-2} & Requerimiento de capital & 3 & \\
\hline Competitividad de precios & \multicolumn{2}{|l|}{-7} & Disponibilidad de información para el comprador & 6 & \\
\hline Reconocimiento de marca & \multicolumn{2}{|l|}{-7} & Nivel de percibido de diferenciación de producto & 6 & \\
\hline Lealtad del cliente & \multicolumn{2}{|l|}{-6} & Costos de cambio & 3 & \\
\hline Variedad de productos & \multicolumn{2}{|l|}{-1} & Mercado comercial & 5 & \\
\hline Confiabilidad & \multicolumn{2}{|l|}{-1} & Poder de los proveedores & 4 & \\
\hline Capacidad de producción & \multicolumn{2}{|l|}{-7} & Acceso a la distribución & 4 & \\
\hline Comercio electrónico & \multirow{2}{*}{\multicolumn{2}{|c|}{$\begin{array}{l}-6 \\
-7\end{array}$}} & & & \\
\hline Servicio postventa & & & & & \\
\hline Promociones & \multicolumn{2}{|l|}{-7} & & & \\
\hline Canales de distribución & \multicolumn{2}{|l|}{-7} & & & \\
\hline \multirow[t]{2}{*}{ Puntualidad } & \multirow[b]{2}{*}{ EJE X } & -4.79 & & & 4.56 \\
\hline & & -0.23 & & EJE Y & 1.71 \\
\hline
\end{tabular}

Nota. Adaptado de Conceptos de Administración Estratégica (p. 179), por F. David, 2013, México, D.F., México: Prentice Hall. Copyrigth 2013 por Pearson Education. 
producto, ya que a pesar de no contar con gran stock de las piezas, la empresa cuenta la variedad de todas sus piezas; Finalmente otro factor fuerte es Servicio al Cliente, siendo la ventaja que quien atiende en la tienda es una de las socias y joyera artesana, quien conoce bastante bien las propiedades de los productos vendidos. Pero se debe buscar una estrategia que genere ventaja competitiva pues el promedio de -4.79 no es bueno.

\section{Posición Estratégica Externa:}

Complementando a lo que el autor indica, en esta posición se describe la estabilidad del entorno y fortaleza industrial de la empresa:

- Estabilidad del Entorno (EE): Tiene la capacidad de mitigar la carencia de la FF de una organización. Los factores determinantes para esta posición fueron calificados del -1 (la mejor) a -7 (la peor) posición estratégica de la estabilidad del entorno de la industria joyera. El promedio de EE para la empresa Incas Jewelry es de -3.17. En cuanto al manejo del entorno, la empresa no puede competir con los precios de la competencia porque la producción de sus piezas que en su mayoría son diseños étnicos propios es caro, mientras que la mayoría ofrece diseños comerciales. Otro punto importante es que el ingreso de los productos sustitutos de Europa y Asia tiene precio bastante bajo lo que desmejora la posición estratégica de la empresa.

- Fortaleza Industrial (FI): Se consideran los factores determinantes que la industria joyera tiene en el entorno externo, los cuales fueron calificadas del +1 (la peor) a +7 (la mejor) posición estratégica de la FF de la industria joyera. El promedio de FI para la empresa Incas Jewelry es de 4.56. La industria de la joyería tiene un buen potencial de crecimiento debido a su estabilidad financiera, la mayoría produce en grandes volúmenes.

Luego de calificar las cuatro posiciones estratégicas, estas se ubican en cuatro cuadrantes, siendo $(-\mathrm{x}, \mathrm{x})$ Ventaja Competitiva, Fortaleza Financiera y este caso salió -4.79 , 4.56 y $(\mathrm{y}, \mathrm{y})$ Estabilidad del Entorno, Fortaleza Financiera, para este caso salió -3.17, 4.88 (ver Tabla 41) Para poder establecer cuál es la postura en la que se encuentra Incas Jewelry SAC y determinar qué tipo de estrategia se va a establecer, se promedia las posiciones de la siguiente manera:

Para hallar $\mathrm{X}=(\mathrm{VC}+\mathrm{FI})$

Para hallar $\mathrm{Y}=(\mathrm{FF}+\mathrm{EE})$ 
En el caso de la empresa Incas Jewelry se tuvo un $\mathrm{X}=-0.23$ y un $\mathrm{Y}=1.69$ colocándola en la postura conservadora. Indicado que la empresa tiene una aceptada Fortaleza Financiera (FF) y baja ventaja competitiva (VC), esta postura es típica de un mercado estable, pero de crecimiento lento. La empresa debe enfocarse en alcanzar estabilidad financiera, siendo su factor crítico la competitividad de sus productos (ver Tabla $32)$.

En 2015, D’Alessio señaló "las organizaciones en esta situación deberían reducir su línea de productos, reducir costos, enfocarse en mejorar su flujo de caja, proteger sus productos competitivos, desarrollar nuevos productos y ganar entrada en mercados más atractivos". Esta es una estrategia en la cual nos enfocaremos en las oportunidades del producto como se mencionó en los puntos utilizados en el modelo del Océano Azul.

En este punto el autor señaló que la "Estrategia Conservadora" hace que la organización pueda hacer algunas cosas mejor que la competencia y capturar ciertos mercados. De acuerdo al análisis de la Matriz PEYEA indica de Incas Jewelry adolece de desventajas competitivas importantes en una industria tecnológicamente estable, pero con ventas descendientes. Este cuadrante plantea cuatro tipos de estrategias:

Tabla 32

Matriz Posición Estratégica y Evaluación de la Acción - MPEYEA

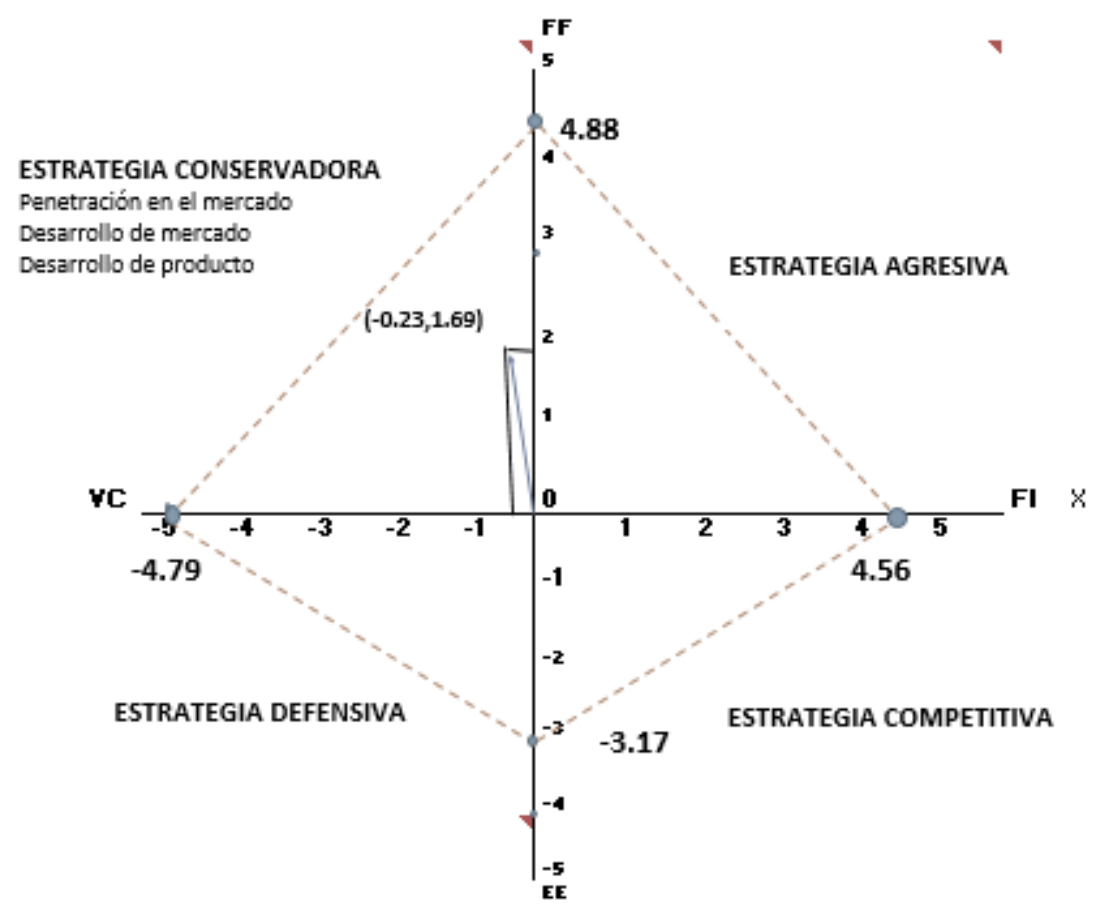

Nota. Adaptado de Conceptos de Administración Estratégica (p. 179), por F. David, 2013, México, D.F., México: Prentice Hall. Copyrigth 2000 por Pearson Education. 
- Penetración en el mercado: Buscar aumentar la participación del mercado para los productos actuales utilizando los medios digitales y ampliando los canales de distribución

- Desarrollo de mercado: Se recomendaría introducir un producto de artesanía aprovechando el ingreso de público extranjero buscando alianzas estratégicas.

- Desarrollo de producto: Se recomendaría incrementar las ventas mojando los productos actuales, utilizando diseños nuevos y buscar la acreditación o certificación de los mismos para que genere confiabilidad de compra.

- Diversificación relacionada: Agregar productos o servicios nuevos pero relacionados con los presentes. La idea es reducir la línea de productos, mejorar el flujo de caja, proteger los productos competitivos.

\subsubsection{Matriz Interna Externa}

En 2015, D’Alessio señaló “La Matriz Interna Externa, llamada MIE fue desarrollada por Mckinsey \& Company para General Electric, como matriz de portafolio y se considera derivada de la matriz de crecimiento de la BCG. Ofrece mayor amplitud para reflejar y evaluar las complejidades de los negocios de una organización multidivisional, pues son múltiples los factores internos y externos determinantes del éxito." Para el autor los pasos para elaborar un MIE son: (a) Identificar los valores de EFE y EFI; (b) Colocar estos valores en la matriz y (c) Según la división, identificar qué tipo de estrategia se debe seguir (ver Figura 14):

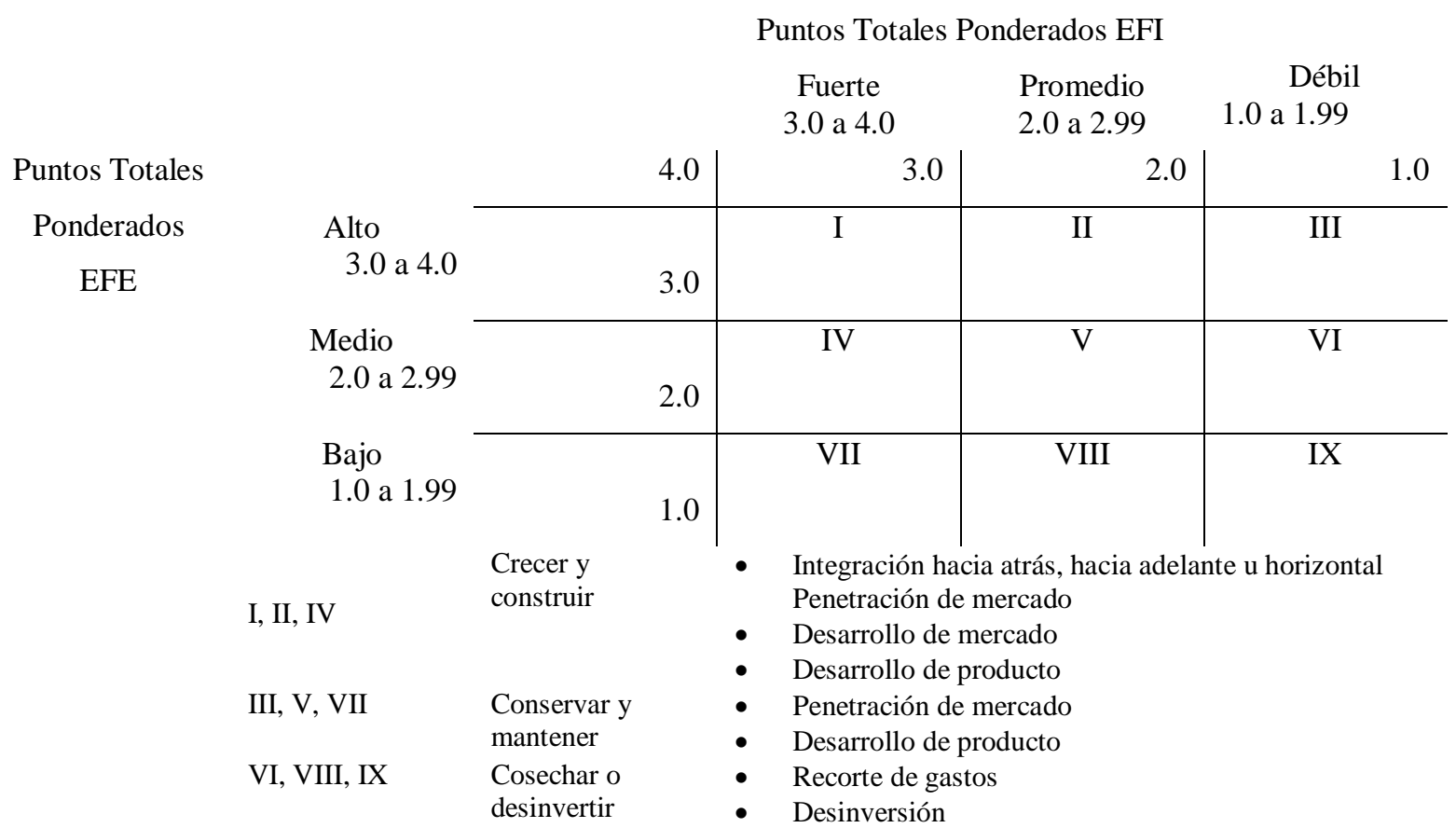

Figura 14. Matriz Interna Externa. Tomado de Proceso Estratégico (p. 288), por F. D’Alessio, 2015, Lima, Perú: Pearson. Copyright 2015 por Pearson Education de Perú S.A. 
En base a los resultados de la matriz EFE presentados en la Tabla 10 y EFI presentados en la Tabla 24, se procedió a graficar la figura 15 y aplicar la Matriz InternaExterna. Matriz EFE tuvo un resultado de 2.35 y EFI 2.66, resultando en el cuadrante V, cuya prescripción es retener y mantener, y sugiere las estrategias: Penetración en el mercado y Desarrollo de productos.

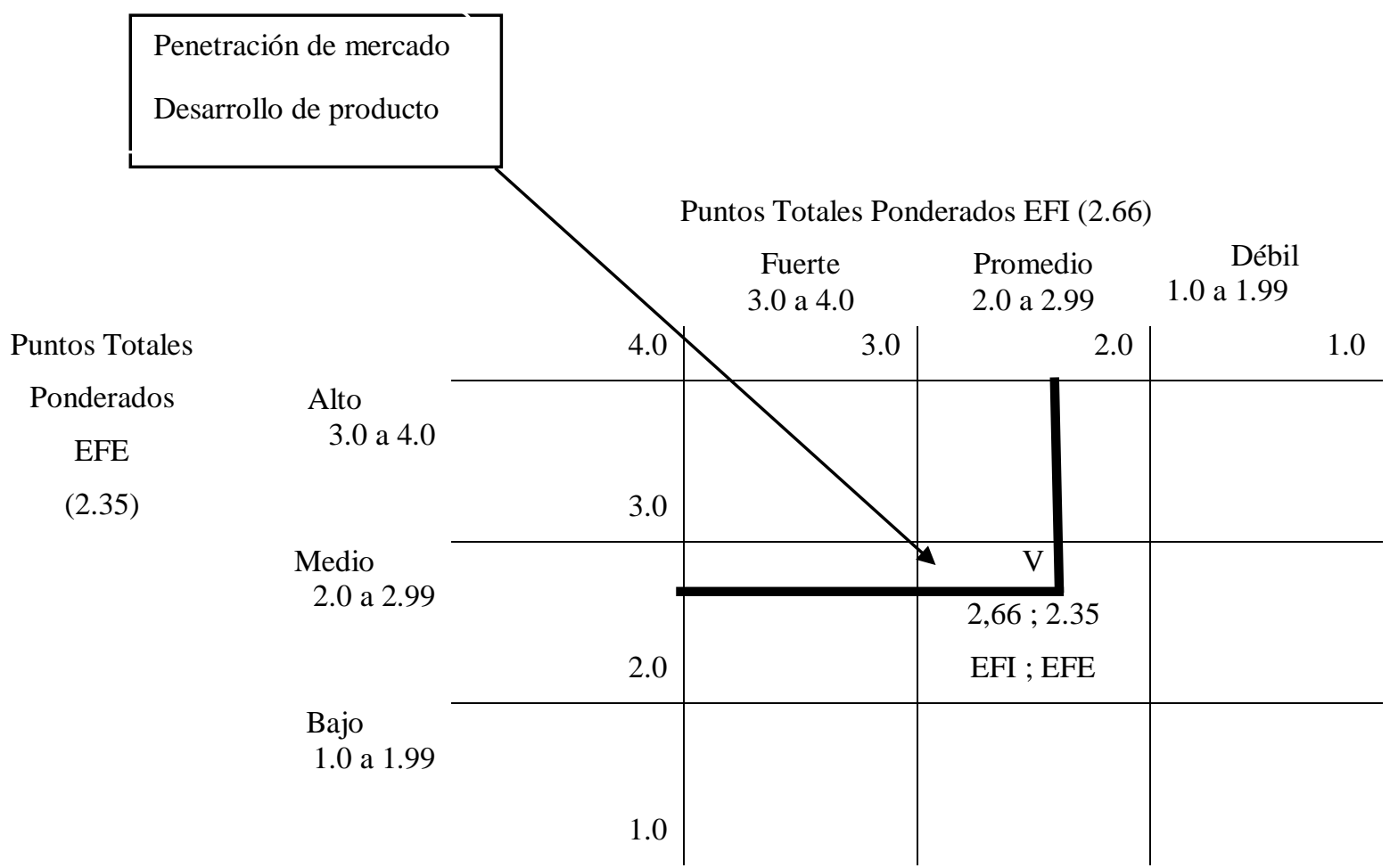

Figura 15. Matriz Interna Externa de Incas Jewelry SAC. Adaptado de Proceso Estratégico (p. 288), por F. D’Alessio, 2015, Lima, Perú: Pearson. Copyright 2015 por Pearson Education de Perú S.A.

Analizando el cuadrante V determinada en el MIE se procede a determinar las estrategias:

- Penetración en el mercado: Buscar una mayor participación de mercado para los productos o servicios presentes en los mercados actuales a través de mayores esfuerzos de marketing. Se propone clasificar las joyas en dos tipos: Diseño étnico y Diseño clásico. Los autores proponemos esta estrategia.

- Desarrollo de producto: Buscando liderar el mercado mediante certificaciones y obteniendo retroalimentación de parte de los clientes.

\subsubsection{Matriz Boston Consulting Group.}

Como David (2013) señaló "La matriz BCG es un método grafico que permite desarrollar un análisis estratégico del portafolio de productos de una empresa en base a dos factores: (a) Tasa de crecimiento de mercado, y (b) la participación del mercado. De esta 
manera, la empresa podrá evaluar si las líneas de negocio que posee ameritan invertir, desinvertir o incluso abandonarlas." (p.182). Asimismo, David señaló que "La matriz BCG (conocida también como matriz de crecimiento-participación) representa gráficamente las diferencias entre divisiones, en términos de su participación relativa en el mercado y de la tasa de crecimiento de la industria. Así, la matriz BCG permite que las organizaciones multidivisionales manejen su cartera de negocios con base a estos dos importantes parámetros, comparando el comportamiento de cada una de sus divisiones con el de las demás.”. Esta matriz el autor la divide en cuatro cuadrantes (ver Figura 16):

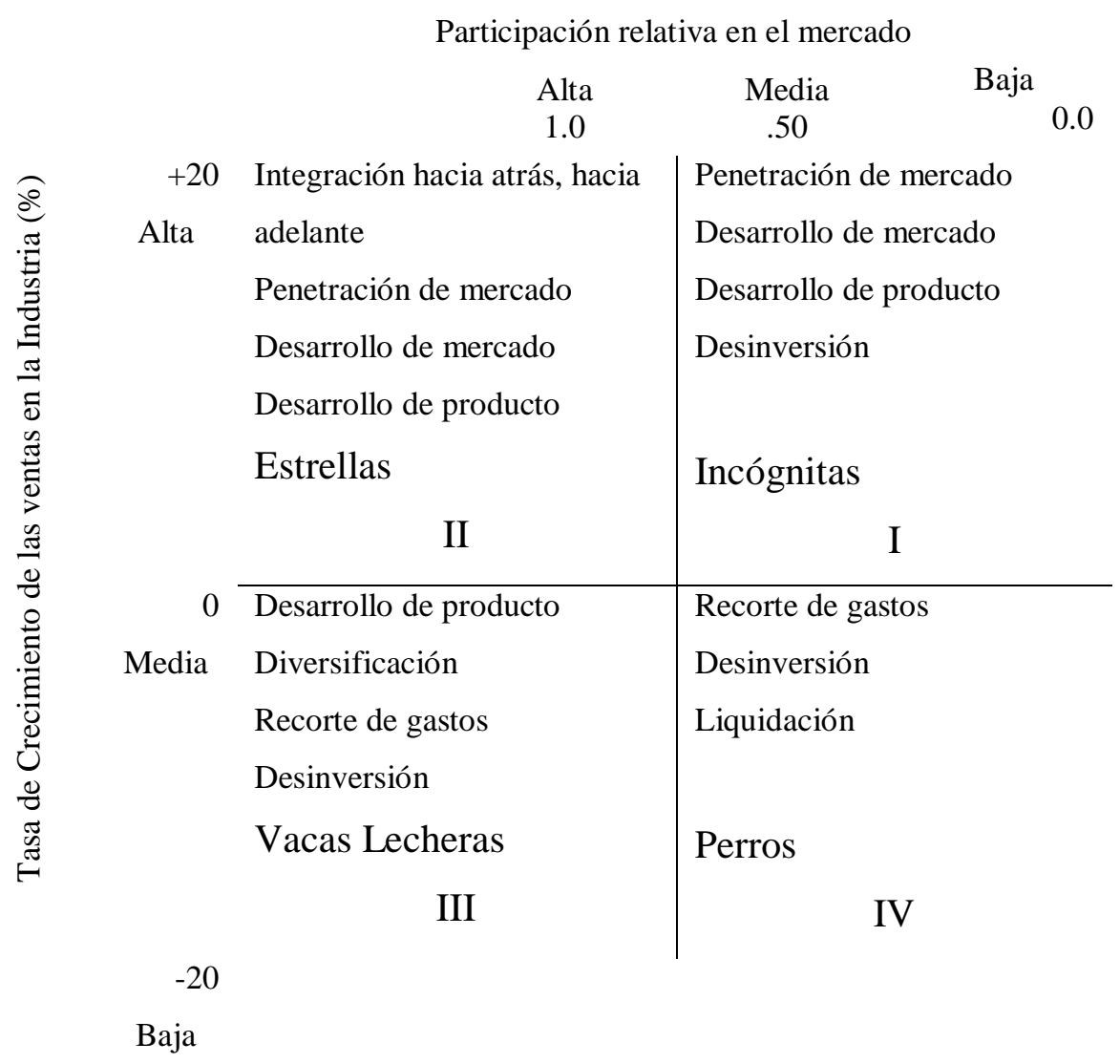

Figura 16. Matriz BCG. Tomado de Conceptos de Administración Estratégica (p. 182), por F. David, 2013, México, D.F., México: Prentice Hall. Copyright 2013 por Pearson Education.

- Cuadrante I: Conocidos como "Incógnitas". Tienen baja participación relativa en el mercado, pero compiten en una industria de alto crecimiento. Por lo general tienen grandes necesidades de efectivo, pero generan pocos ingresos. Se recomienda estrategias intensivas como penetración de mercado, desarrollo de producto o desarrollo de mercado o venderlos

- Cuadrante II: Conocidos como “estrellas”. Tienen alta participación relativa en el mercado. Deben recibir considerables inversiones para conservar o fortalecer sus 
posiciones dominantes. Se recomienda estrategias como integración hacia adelante, la integración hacia atrás, la integración horizontal, penetración de mercado, desarrollo de producto y desarrollo de mercado.

- Cuadrante III: Conocidos como "vacas lecheras". Tienen alta participación relativa en el mercado, pero compiten en una industria de bajo crecimiento. Generan más efectivo del que necesitan, así que frecuentemente se les debe “ordeñar”. Antes de ser vacas lecheras, muchos negocios fueron estrellas. Las divisiones consideradas vacas lecheras deben ser manejadas de manera que conserven su sólida posición durante tanto tiempo como sea posible. Se recomienda estrategias como desarrollo de productos o la diversificación podrían ser estrategias atractivas para los negocios fuertes que entran en esta clasificación.

- Cuadrante IV: Conocidos como "perros". Tienen baja participación relativa en el mercado y compiten en una industria de lento crecimiento o de crecimiento nulo; Tienen una posición interna y externa débil, con frecuencia la dirección termina por liquidarlas, desinvertir en ellas o reducirlas a través del recorte de gastos. Se recomienda estrategias como recorte de gastos, pues muchas veces una estricta reducción de activos y costos le servirá de impulso para recuperarse y alcanzar de nuevo su viabilidad y rentabilidad.

De acuerdo a la información brindada por la empresa Incas Jewelry SAC, se procede a formar la Matriz BCG, importante mencionar que se ha tomado en cuenta solo los productos de mayor rotación y comparando cuál de ellos tiene mayor volumen de venta (ver Tabla 33).

Tabla 33. Participación de Mercado y Tasa de Crecimiento

Participación de Mercado y Tasa de Crecimiento

\begin{tabular}{|c|c|c|c|c|c|c|c|}
\hline \multirow{2}{*}{$\begin{array}{c}\text { Unidad de } \\
\text { negocio }\end{array}$} & \multicolumn{2}{|l|}{2017} & \multicolumn{2}{|l|}{2018} & \multirow{2}{*}{$\begin{array}{c}\text { Tasa } \\
\text { crecimiento }\end{array}$} & \multirow{2}{*}{$\begin{array}{c}\text { Tasa } \\
\text { relativa }\end{array}$} & \\
\hline & Ventas año 1 & $\%$ & Ventas año 2 & $\%$ & & & \\
\hline Anillos & 18,340 & $32 \%$ & 19,159 & $32 \%$ & $4 \%$ & 1.52 & Estrella \\
\hline Aretes & 12,270 & $21 \%$ & 12,581 & $21 \%$ & $3 \%$ & 0.66 & Incógnita \\
\hline Pulseras & 10,952 & $19 \%$ & 11,243 & $19 \%$ & $3 \%$ & 0.59 & Incógnita \\
\hline Cadenas & 7,693 & $13 \%$ & 7,735 & $13 \%$ & $1 \%$ & 0.40 & Perros \\
\hline Otros & 5,700 & $10 \%$ & 4,900 & $8 \%$ & $-14 \%$ & 0.26 & Perros \\
\hline Retablos & 1,578 & $55 \%$ & 2,150 & $53 \%$ & $36 \%$ & 0.11 & Incógnita \\
\hline Artesanía & 1,268 & $45 \%$ & 1,880 & $47 \%$ & $48 \%$ & 0.10 & Incógnita \\
\hline Total & 57,801 & & 59,648 & & & & \\
\hline
\end{tabular}

Nota. Adaptado de Conceptos de Administración Estratégica (p.182), por F. David, 2013, México, D.F., México: Prentice Hall. Copyrigth 2013 por Pearson Education. 
Se procede a explicar la Matriz BCG de los productos que Incas Jewelry SAC ofrece (ver Tabla 34):

- Estrellas: El producto anillo es considerado el producto estrella de la empresa con una participación de 4\%. David (2013) Recomienda "estrategias intensivas como penetración de mercado, desarrollo de mercado o desarrollo de producto. $\mathrm{O}$ estrategias de integración vertical hacia adelante, hacia atrás, horizontal)". Los autores recomiendan estrategia de penetración de mercado porque se cuenta con buena fuerza de ventas en este producto, quien lo vende en tienda es quien los produce y lo conoce bien.

Incógnitas: Los productos ubicados en este cuadrante se encuentran las artesanías con una participación de $48 \%$, seguidos de retablos con $36 \%$, luego aretes y pulseras 3\%. Asimismo, David (2013) recomendó “estrategias de penetración de mercado, desarrollo de mercados y desarrollo de productos". Los autores recomiendan penetración de mercado aumentando la participación del mercado con los productos actuales. Si bien están en este cuadrante tiene posibilidad de salir adelante pues son productos con gran posicionamiento en el sector joyero y los mercados de lo componen.

- Vacas: La empresa no cuenta con ningún producto en este cuadrante.

- Perro: El producto cadena tiene una pequeña participación en el mercado de $1 \%$, y otros referidos a los demás productos, como gemelos y dijes tienen una participación de -14\% David (2013). Recomienda "estrategias de reducción, liquidación, desinversión"

Los autores proponen que estos productos deben manearse estrategias de reducción, adquiriéndolos o produciéndolos solo a pedidos y no tenerlos en exhibición. O establecer estrategias de aventura conjunta buscando un socio.

\subsubsection{Matriz de la Gran Estrategia.}

Como David (2013) señaló “Todas las organizaciones (y las divisiones de las mismas) pueden hallar su lugar en uno de los cuatro cuadrantes de estrategias de esta matriz. La matriz de la estrategia principal se basa en dos dimensiones de valoración: la posición competitiva y crecimiento del mercado (o industria).” (p.189). Esta matriz el autor la divide en cuatro cuadrantes (ver Figura 17): 
Tabla 34

Matriz BCG Incas Jewelry SAC

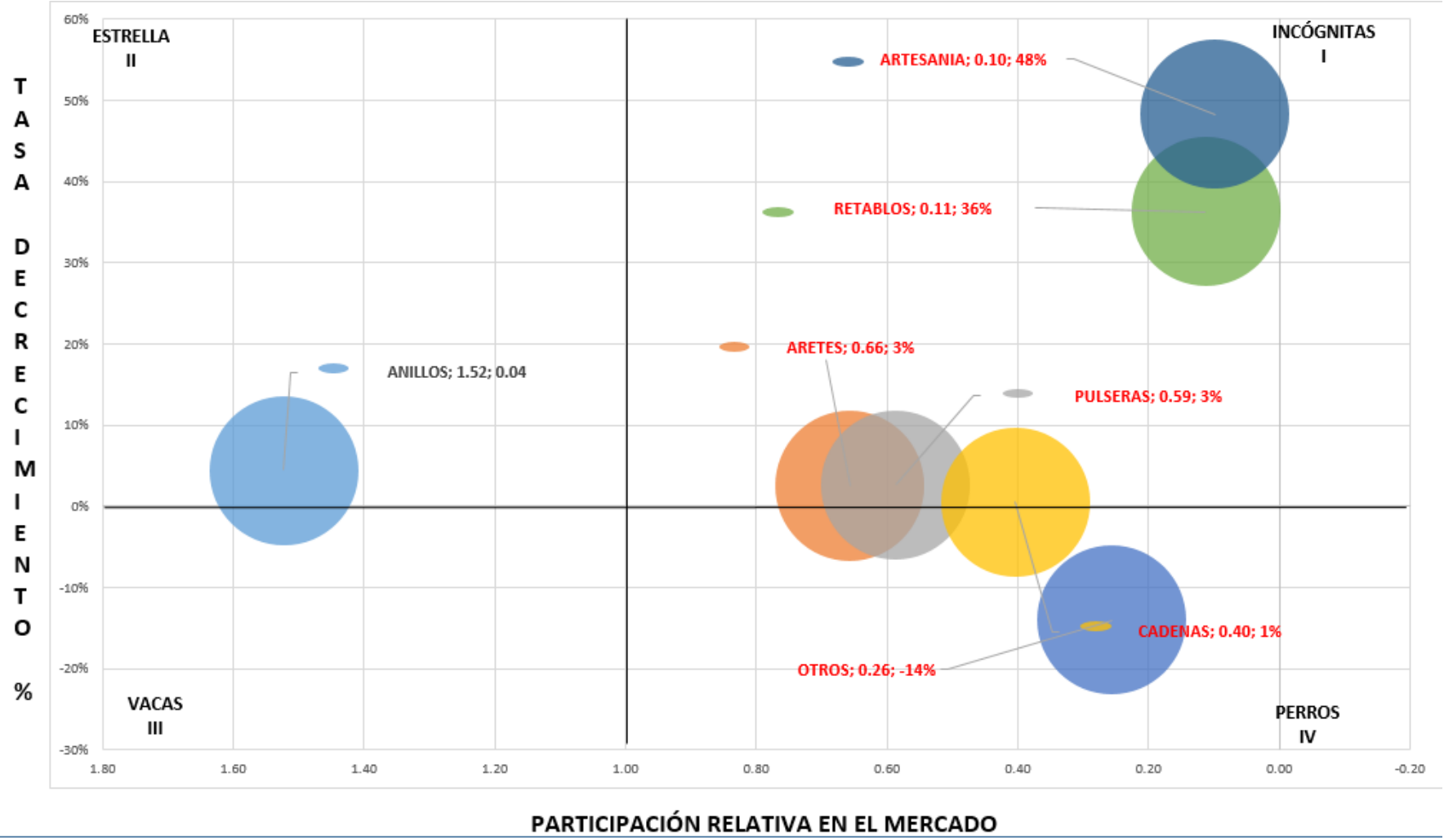

Nota. Adaptado de Conceptos de Administración Estratégica (p.182), por F. David, 2013, México, D.F., México: Prentice Hall. Copyrigth 2013 por Pearson Education. 


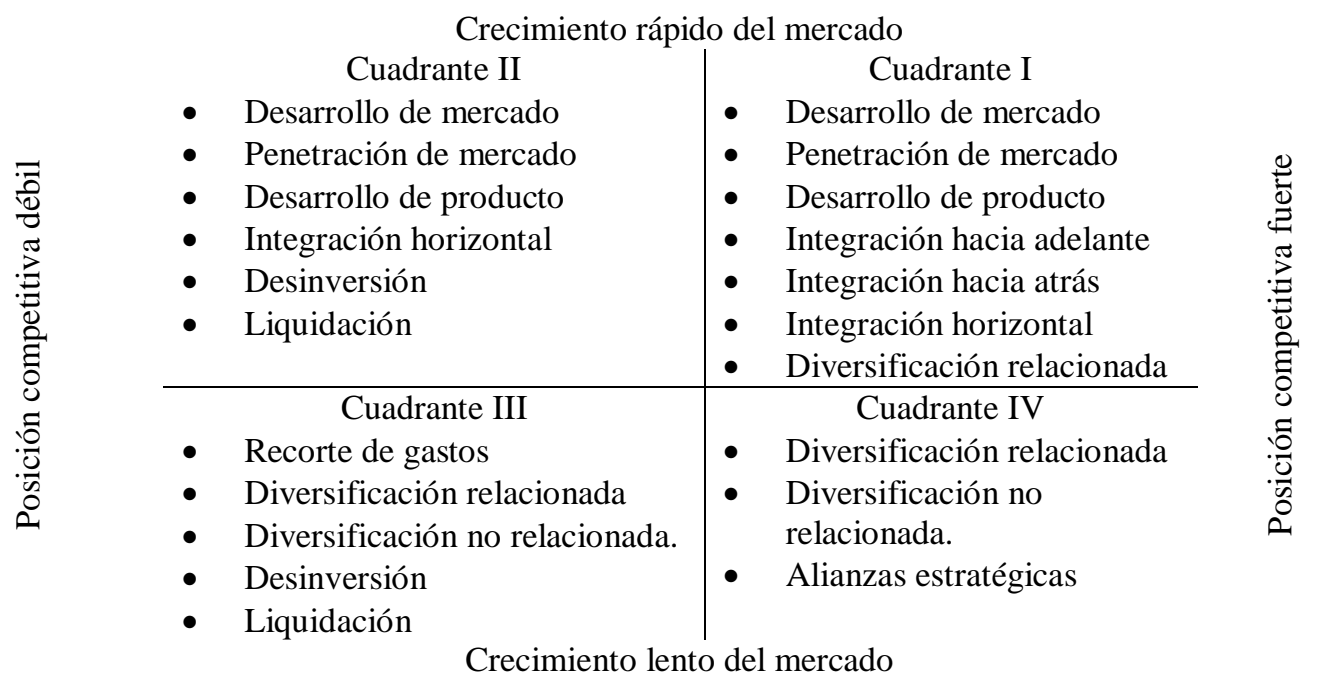

Figura 17. Matriz de la Gran Estrategia. Tomado de Conceptos de Administración Estratégica (p. 189), por F. David, 2013, México, D.F., México: Prentice Hall. Copyright 2013 por Pearson Education.

- Cuadrante I: Estas empresas muestran una excelente posición estratégica. Una estrategia adecuada para ellas es la concentración ininterrumpida en los mercados (penetración de mercado y desarrollo de mercado) y productos actuales (desarrollo de producto). No es aconsejable que las organizaciones localizadas en el cuadrante realicen cambios notables en sus ventajas competitivas ya consolidadas. Cuando la organización del cuadrante I tiene un exceso de recursos, las estrategias efectivas son la integración hacia atrás, la integración hacia adelante y la integración horizontal. Si la empresa del cuadrante I está demasiado enfocada en un solo producto, la diversificación relacionada podría reducir los riesgos asociados al ampliar la línea de productos. Las empresas del cuadrante I pueden permitirse aprovechar las oportunidades externas que se presentan en varias áreas, e incluso asumir riesgos de manera decidida cuando sea necesario.

- Cuadrante II: Estas empresas deben evaluar seriamente su enfoque actual de acercamiento al mercado. Aunque su industria esté creciendo, son incapaces de competir con efectividad y necesitan determinar por qué su enfoque actual es inefectivo y de qué manera pueden cambiar para mejorar su competitividad. Como las empresas del cuadrante II están en una industria con un rápido crecimiento de mercado, por lo general la primera opción a considerar es la estrategia intensiva (a diferencia de una estrategia integrativa o de diversificación). Sin embargo, si la empresa carece de una competencia distintiva o no tiene una ventaja competitiva, casi siempre la integración horizontal será una alternativa deseable. La 
desinversión o liquidación pueden considerarse un último recurso. La desinversión podría proporcionar los fondos necesarios para adquirir otra empresa o recomprar las acciones.

- Cuadrante III: Estas organizaciones compiten en industrias de lento crecimiento y tienen una posición competitiva débil. Estas empresas deben aplicar con rapidez algunos cambios drásticos para evitar un mayor deterioro o la posible liquidación. En primer lugar, se deben implementar extensas reducciones de costos y activos (recorte de gastos). Una estrategia alternativa consiste en retirar los recursos de los negocios actuales y asignarlos a diferentes áreas (diversificación). Si todo esto falla, las opciones finales para las empresas del cuadrante II son la desinversión o la liquidación.

- Cuadrante IV: Estas empresas tienen una sólida posición competitiva, pero se encuentran en una industria de lento crecimiento. Estas organizaciones tienen la fuerza para lanzar programas diversificados en áreas más prometedoras: Se caracterizan por tener altos niveles de flujo de efectivo y necesidades de crecimiento limitadas, y con frecuencia son capaces de implementar con éxito las estrategias de diversificación relacionada y no relacionada. Además, pueden formar alianzas estratégicas.

Según la tabla 35, la empresa Incas Jewelry SAC se encuentra en el cuadrante II, pues la industria de la joyería está en un rápido crecimiento, pero la empresa debido a su MPC analizado en el capítulo V tiene una posición competitiva débil. Se recomienda la estrategia penetración en el mercado. De acuerdo al análisis realizado, la empresa presenta una baja posición competitiva ya que mantiene una participación del mercado del $3 \%$ en la mayoría de sus productos. Y tiene débil posición competitiva (-4.8) según el análisis realizado en MPEYEA según los datos de MPC.

\subsection{Resumen de las Estrategias Formuladas}

Las matrices desarrolladas para la formulación de estrategias como: Océano Azul, FODA, PEYEA, IE, BCG y la Gran Estrategia permitieron analizar las diferentes estrategias propuestas en cada una de ellas y de acuerdo a los factores internos y externos de la empresa en estudio se pudo determinar qué estrategia se podría aplicar. En la tabla se presenta el resumen de las estrategias formuladas identificando en el total el número de estrategias 
Tabla 35

Matriz de la Gran Estrategia de Incas Jewelry

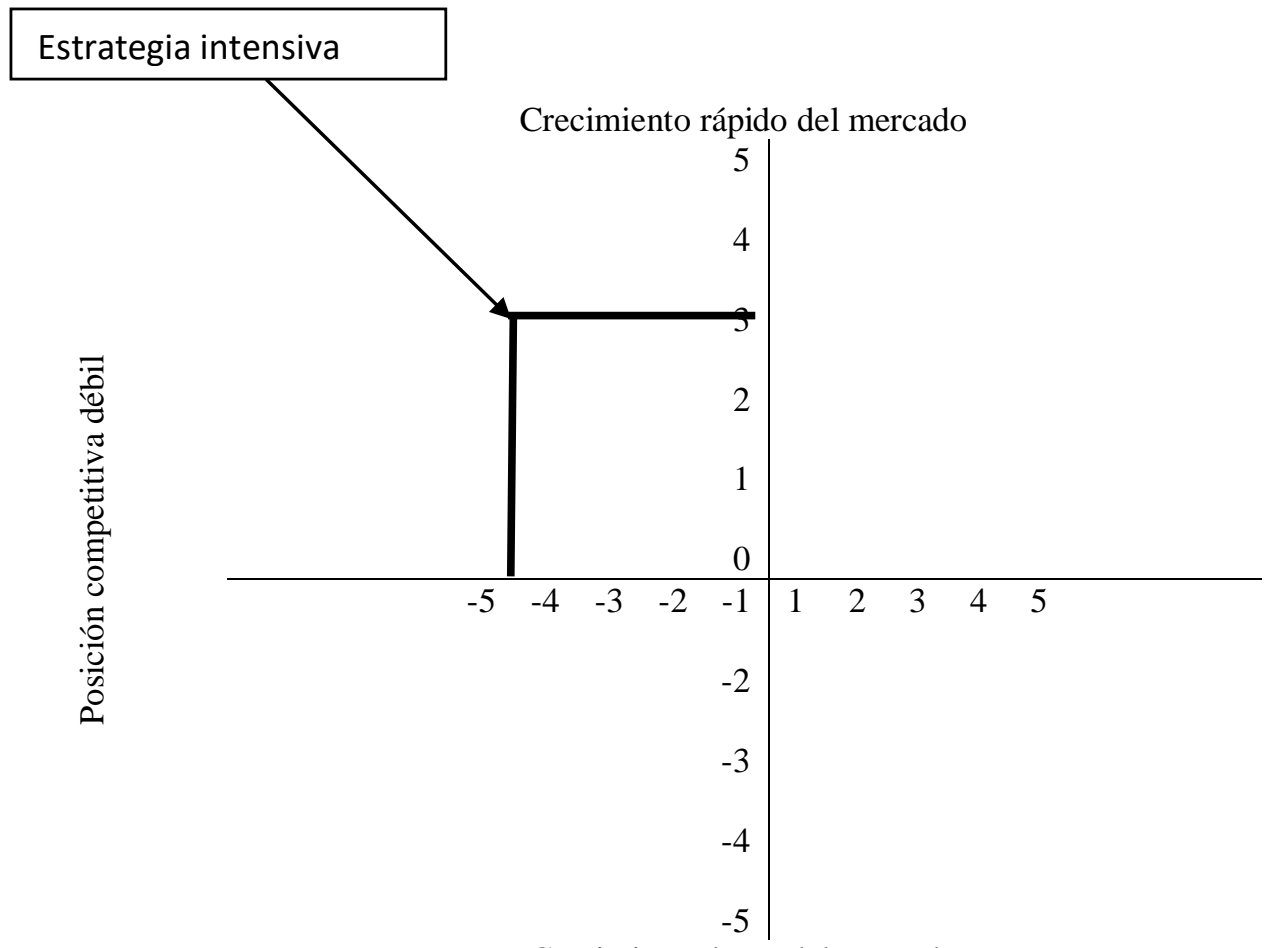

Crecimiento lento del mercado

Nota. Adaptado de Conceptos de Administración Estratégica (p.137), por F. David, 2013, México, D.F., México: Prentice Hall. Copyrigth 2013 por Pearson Education.

utilizadas en cada matriz (ver Tabla 36). Se colocarán las estrategias de mayor (5 puntos) a menor puntuación (1 punto) seguida de lo que David define. Las estrategias de puntuación 5 (más alta) es: Penetración de mercado y en el 2013, David estableció que esta estrategia "Busca una mayor participación de mercado para los productos o servicios presentes en los mercados actuales a través de mayores esfuerzos de marketing” (p. 137)

Tabla 36

Resumen de las Estrategias Formuladas

\begin{tabular}{|c|c|c|c|c|c|c|}
\hline Estrategias & FODA & PEYEA & IE & $\mathrm{BCG}$ & GE & Total \\
\hline Penetración de mercado & $\mathrm{X}$ & $\mathrm{X}$ & $\mathrm{X}$ & $\mathrm{X}$ & $\mathrm{X}$ & 5 \\
\hline Desarrollo de producto & $\mathrm{X}$ & $\mathrm{X}$ & $\mathrm{X}$ & $\mathrm{X}$ & $\mathrm{x}$ & 5 \\
\hline Desarrollo de mercado & & $\mathrm{x}$ & & $\mathrm{X}$ & $\mathrm{x}$ & 3 \\
\hline Integración horizontal & & & & $\mathrm{x}$ & $\mathrm{x}$ & 2 \\
\hline Desinversión & & & & $\mathrm{X}$ & $\mathrm{x}$ & 2 \\
\hline Liquidación & & & & $\mathrm{x}$ & $\mathrm{x}$ & 2 \\
\hline Integración hacia atrás & & & & $\mathrm{X}$ & $\mathrm{x}$ & 2 \\
\hline Integración hacia delante & & & & $\mathrm{x}$ & $\mathrm{x}$ & 2 \\
\hline Diversificación relacionada & $\mathrm{X}$ & $\mathrm{x}$ & & & & 2 \\
\hline Recorte de gasto & $\mathrm{X}$ & & & & $\mathrm{x}$ & 2 \\
\hline
\end{tabular}

Nota. Las x significan que esa estrategia está en la matriz señalada. Adaptado de Conceptos de Administración Estratégica (p.137), por F. David, 2013, México, D.F., México: Prentice Hall. Copyrigth 2013 por Pearson Education. 
La estrategia de puntuación 4 es: y Desarrollo de productos "Buscar aumentar las ventas a través de la mejora de los productos o servicios presentes o el desarrollo de nuevos" La estrategia de puntuación 3 es: Desarrollo de mercados "Introducir los productos o servicios presentes en una nueva área geográfica" Las estrategias de puntuación 2 son: Integración horizontal "Buscar apropiarse de los competidores o aumentar el control sobre los mismos"; Desinversión "Venta de una división o de una parte de la organización" y Liquidación "Venta de todos los activos de la empresa, en partes, por su valor tangible"

Las estrategias de puntuación 1 son: Integración hacia atrás "Buscar apropiarse de los proveedores de una empresa o aumentar el control sobre los mismos", Integración hacia delante "Apropiarse de los distribuidores o vendedores al detalle, o incrementar el control sobre ellos", Diversificación relacionada "Agregar productos o servicios nuevos pero relacionados con los presentes" y Recorte de gasto "Reorganización a través de la reducción de costos y activos, con el propósito de revertir la caída de las ventas y las utilidades" Se procede a colocar las estrategias identificadas en las matrices (ver Tabla 37)

Tabla 37

Estrategias de las Matrices Sugeridas a Incas Jewelry SAC

\begin{tabular}{|c|c|}
\hline & Estrategia \\
\hline $\begin{array}{l}\text { Penetración de } \\
\text { mercado }\end{array}$ & $\begin{array}{l}\text { Para buscar una mayor participación de mercado para los productos o } \\
\text { servicios presentes en los mercados actuales a través de mayores } \\
\text { esfuerzos de marketing }\end{array}$ \\
\hline $\begin{array}{l}\text { Desarrollo de } \\
\text { producto }\end{array}$ & $\begin{array}{l}\text { Para incrementar las ventas mojando los productos actuales, utilizando } \\
\text { diseños nuevos y buscar la acreditación o certificación de los mismos } \\
\text { para que genere confiabilidad de compra y alineando la gestión de } \\
\text { compra a proveedores. }\end{array}$ \\
\hline $\begin{array}{l}\text { Desarrollo de } \\
\text { mercado }\end{array}$ & Para buscar la globalización de la empresa en ferias locales. \\
\hline Desinversión & Vendiendo una división de los productos ofrecidos. \\
\hline Liquidación & Vendiendo los activos que generan perdida a su valor tangible. \\
\hline $\begin{array}{l}\text { Diversificación } \\
\text { relacionada }\end{array}$ & Agregando productos relacionada con el actual \\
\hline Recorte de gasto & A través de la reducción de costos \\
\hline
\end{tabular}




\section{Capítulo VIII: Selección de la Estrategia}

Con las matrices y lienzos realizados en el capítulo anterior, en esta parte se logra seleccionar cual es la estrategia siguiendo los criterios de selección, descripción de escenarios, comparación de estrategias con escenarios, se elabora la matriz de planeación estratégica cuantitativa MPEC, lo que determina cual es la estrategia que se utilizará para la empresa y cuál es la estrategia contingente.

\subsection{Método Factores Estratégicos Claves}

Las organizaciones compiten por obtener clientes y la estrategia competitiva está relacionada, esencialmente, en dar respuesta a cómo las organizaciones cubren las necesidades de los mismos de forma más efectiva que sus competidores. David Faulkner y Cliff Bowman (1995).

\subsubsection{Criterios de selección.}

En 1995, Bowman desarrolló una herramienta llamada "The Customer Matrix" o la "Matriz del Cliente", pero más conocida como "El Reloj Estratégico de Bowman" por la forma que tiene, en ella es posible encontrar rutas de éxito en las estrategias competitivas que la relación entre el valor percibido por el cliente y el precio pagado por el producto o servicio (ver Figura 18).

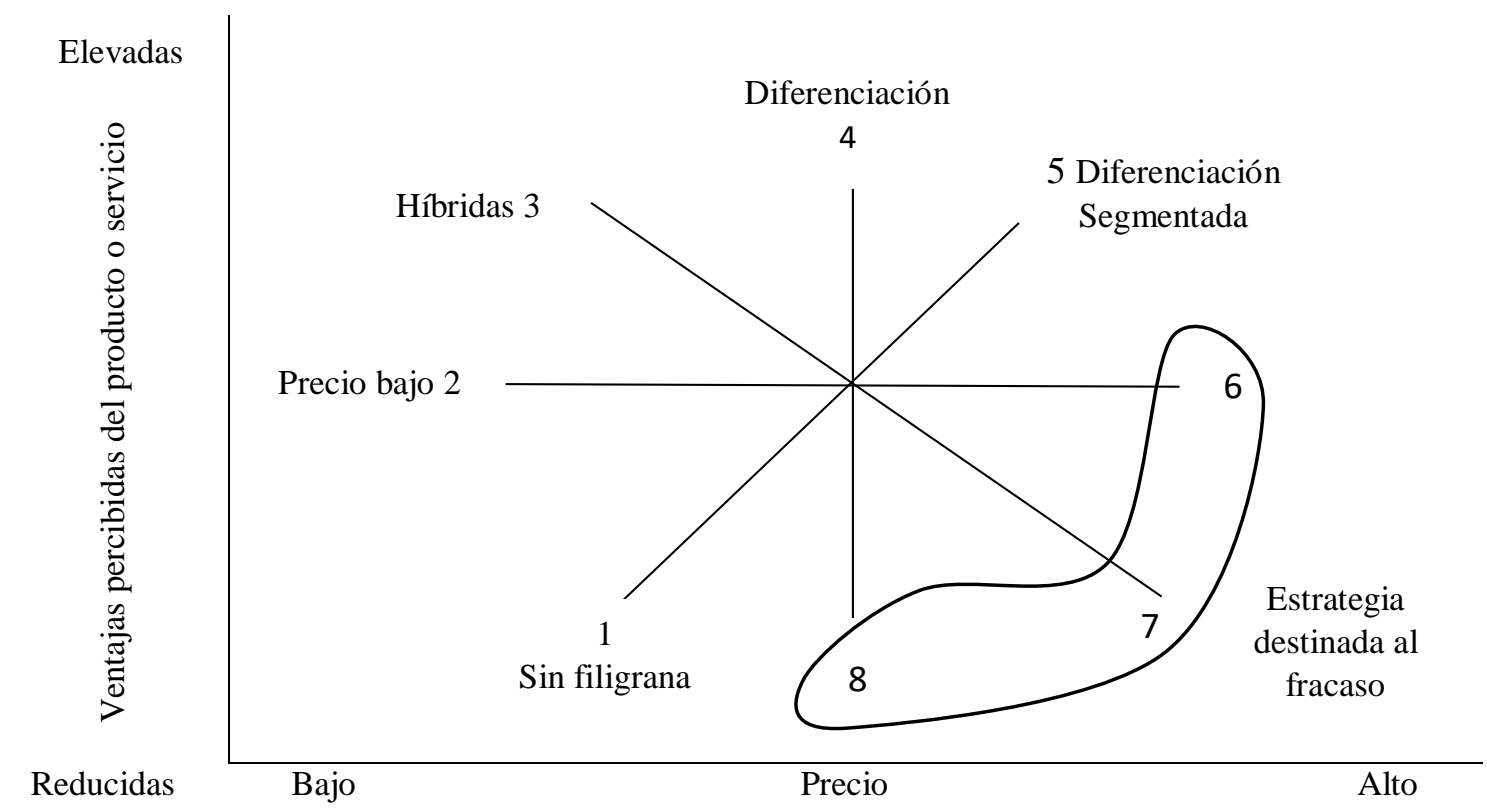

Figura 18. El Reloj Estratégico de Bowman. Tomado de Competitive Strategy (p. 189), por M. Porter, 1980, New York: Prentice Hall. Copyright 2013 por Harvard School Publishing Corporation.

El eje vertical tiene niveles bajos y altos de valor percibido (satisfacción) por el comprador al adquirir y usar un producto o servicio. El eje de horizontal tiene los niveles bajos y altos de precio percibido por parte del comprador. El precio percibido no corresponde necesariamente al coste inicial 
pagado por el bien o servicio, sino también con aquellos costos o gastos derivados de su adquisición en el futuro. Se procede a colocar las rutas descritas por el autor:

- Opción 1- Reducir el precio (Ruta2) reducir el precio percibido manteniendo el nivel de valor percibido debería conducir a una organización a aumentar su cuota de mercado; ya que su posición competitiva es mejor que antes. Sin embargo, esto va a depender del tipo de producto servicio ofertado; ya que en algunos mercados los compradores identifican unos menores precios con un menor valor percibido.

- Opción 2 - Aumentar el valor percibido (Ruta 4) La segunda opción estratégica es aumentar el valor percibido sin modificar el precio percibido. Esta estrategia, denominada de "diferenciación”, busca centrarse en un segmento específico del mercado, lo que requiere, previamente, que la organización tenga claro a qué segmento de mercado quiere dirigirse. Esto implicar tener un conocimiento exhaustivo de las necesidades de dicho segmento y ser capaz de conocer cómo este segmento va a evaluar las distintas ofertas de productos o servicios.

- Opción 3 - Reducir el precio y el valor percibido (Ruta 1) Reducir el precio y el valor percibido, de forma simultánea, puede conducir a la organización a un nuevo segmento de mercado (más bajo). Este movimiento puede ser peligroso, desarrollado sobre un producto específico, si puede tener efectos contaminantes sobre el resto de los productos (por ejemplo, que el mercado empiece a reducir el valor percibido del resto de los productos, lo que podría provocar una reducción del precio de venta para volver a la situación original).

- Opción 4 - Estrategia Híbrida (Ruta 3) Esta estrategia se desarrolla cuando es posible aumentar el valor percibido al mismo tiempo que pueden reducirse los precios. El éxito de esta estrategia va a depender de la habilidad de la organización

de entender las necesidades de los clientes y proporcionarles el producto o servicio adecuado, a la vez que la organización dispone de las bases para reducir los costes que posibiliten la reducción del precio y que esto, a su vez, sea difícil de imitar.

- Opción 5 - Diferenciación Focalizada (Ruta 5) El éxito de esta estrategia depende de la existencia de un segmento de mercado que sea capaz de pagar mayores precios a cambio de un mayor valor percibido y de la facilidad con que dicho aumento de valor percibido pueda ser imitado por los competidores. 
- Opción 6 - Aumentar del precio percibido manteniendo el valor percibido (Ruta 6) Aumentar el precio percibido sin alterar el valor percibido sólo puede tener éxito (mayor rentabilidad) si los competidores imitan el movimiento iniciado por la organización y si existe demanda suficiente en el mercado para soportar tal movimiento.

- Opción 7 - Aumentar el precio percibido y reducir el valor percibido (Ruta 7) Esta ruta sólo es factible en situaciones donde existan restricciones al suministro. Incluso en estos casos, provoca decepción en el mercado y únicamente puede sostenerse en el corto plazo, por lo que también suele ser considerada como una ruta de fracaso.

- Opción 8 - Reducir el valor percibido manteniendo el precio (ruta 8) Esta ruta es muy peligrosa porque puede desarrollarse de manera inadvertida por parte de la organización (por ejemplo, en un intento de mantener o reducir los costes para sostener el precio podrían suprimirse atributos valorados por el mercado; por ejemplo, una reducción en la calidad del servicio prestado post-venta). Suele producirse, en consecuencia, cuando la organización no es consciente de los atributos del valor percibido por parte del mercado y cómo dichos atributos son valorados por parte de los consumidores, lo que conduce en el largo plazo a una pérdida de cuota de mercado. En consecuencia, suele también ser catalogada como una ruta de fracaso.

De acuerdo con este criterio de selección, la Opción 5 referida a Diferenciación Focalizada perteneciente a la Ruta 5 fue la elegida debido a que la empresa ofrece productos que crean valor ya que los diseños ofrecidos tienen un estilo étnico único y particular y los clientes que lo adquieren pagan costos altos reconociendo de esta manera el trabajo en cuanto a calidad y diseño.

\subsubsection{Matriz de selección.}

Para la elaboración de esta matriz se utilizó la Matriz de Decisión Estratégica (MDE), determinando que las estrategias de Penetración de Mercado y Desarrollo de producto son aquellas presentes en todas las matrices: Para ello se siguen los siguientes pasos (ver Tabla 38):

1. Colocar en la primera columna las estrategias externas específicas, tomadas del FODA. 
2. Colocar en segunda columna las estrategias alternativas correspondientes de la primera

3. En las siguientes columnas colocar FODA, PEYEA, BCG, IE y GE.

4. Marcar con una $x$ las estrategias utilizadas en cada una de las matrices utilizadas.

5. Sumar las x totales a la derecha.

6. Quedarse solo con las que sumen 3,4 y 5.

Tabla 38

Matriz de Decisión Estratégica (MDE)

\begin{tabular}{lcccccc}
\hline Estrategias especificas & FODA & PEYEA & BCG & IE & GE & Total \\
\hline Penetración de mercado & $\mathrm{x}$ & $\mathrm{x}$ & $\mathrm{x}$ & $\mathrm{x}$ & $\mathrm{x}$ & 5 \\
\hline Desarrollo de producto & $\mathrm{x}$ & $\mathrm{x}$ & $\mathrm{x}$ & $\mathrm{x}$ & $\mathrm{x}$ & 5 \\
\hline $\begin{array}{l}\text { Diversificación } \\
\text { relacionada }\end{array}$ & $\mathrm{x}$ & - & $\mathrm{x}$ & - & & 2 \\
\hline Recorte de gastos & $\mathrm{x}$ & - & $\mathrm{x}$ & - & & 2 \\
\hline Liquidación & $\mathrm{x}$ & - & $\mathrm{x}$ & - & $\mathrm{x}$ & 3 \\
\hline
\end{tabular}

Nota. Las x representan que se encuentran en la matriz señalada y el guión que no se encuentran en ella. Tomado de Proceso Estratégico (p.367), por F. D’Alessio, 2015, Lima, Perú: Pearson 2013 por Pearson Educación de Perú S.A.

\subsection{Método de Escenarios}

En 2015, Godot estableció que en un mundo con las características del actual (donde el ambiente externo es complejo e incierto, donde la velocidad de los cambios y los eventos inesperados se vuelven cada vez más frecuentes), es urgente tener una visión de futuro que permita tomar las previsiones necesarias. Godot (2015). Los escenarios se plantearán en base a las variables del entorno externo vistas en el capítulo IV, siendo Análisis PolíticoGubernamental, Económico, Legal, Cultural, Tecnológico y Ecológico. Puesto que la evolución de estas variables no es conocida con exactitud, el autor propone realizar hipótesis según dos escenarios: el probable y menos probable.

\subsubsection{Descripción de escenarios considerados.}

Se procede a describir el escenario o situaciones planteadas tomando en cuenta el periodo de estudio de los próximos dos años, basados en el análisis del entorno externo visto en el capítulo IV. Por lo analizado se procede a definir el contexto de las tendencias del entorno según PESTE (ver Tabla 39). Asimismo, analizar los escenarios de ocurrencia de lo más probable y lo menos probable (ver Tabla 40). Estos escenarios deberán ser contrastados con las estrategias seleccionadas en el capítulo 8.1.2, con la finalidad de determinar cuál de ellas es la que mejor se adapta a lo que necesita la empresa en estudio, por ello se procede a describirlos: 
Tabla 39

\section{Definición de Contextos}

\begin{tabular}{|c|c|c|c|}
\hline Tendencia del entorno & $\begin{array}{c}1 \\
\text { (Sin variación) }\end{array}$ & $\begin{array}{c}2 \\
\text { (Optimista) }\end{array}$ & $\begin{array}{c}3 \\
\text { (Pesimista) }\end{array}$ \\
\hline \multicolumn{4}{|l|}{ Político } \\
\hline Gobernabilidad política & Sin cambios & $\begin{array}{l}\text { Mayor estabilidad } \\
\text { política }\end{array}$ & Incertidumbre \\
\hline \multicolumn{4}{|l|}{ Económico } \\
\hline PBI & Estable $3.5 \%-3.4 \%$ & Alto $>4 \%$ & Bajo $<3 \%$ \\
\hline Factores de importaciones y & Importación =9.7\% & Importación $>9.7 \%$ & Importación $<9.7 \%$ \\
\hline exportaciones & Exportación $=17.4 \%$ & $\begin{array}{l}\text { Exportación > } \\
17.4 \%\end{array}$ & $\begin{array}{l}\text { Exportación < } \\
17.4 \%\end{array}$ \\
\hline Patrones de consumo & Sin cambio & $\begin{array}{l}\text { Incremento de } \\
\text { consumo }\end{array}$ & $\begin{array}{l}\text { Desaceleración de } \\
\text { consumo }\end{array}$ \\
\hline Mercado comercial & Sin cambio & Alto crecimiento & Desacelera \\
\hline Inflación & Se mantiene & Se reduce & Se incrementa \\
\hline Impuestos & Se mantiene & Se reduce & Se incrementa \\
\hline Empleo & Se mantiene & Crece empleo & Crece desempleo \\
\hline \multicolumn{4}{|l|}{ Legal } \\
\hline Legislación & Sin variación & Política de apertura & Política restrictiva \\
\hline Certificación & Se mantiene & Alto acceso & Acceso limitado \\
\hline \multicolumn{4}{|l|}{ Cultural } \\
\hline Estilo de vida & Se mantiene & Mejora & Acceso limitado \\
\hline \multicolumn{4}{|l|}{ Tecnológico } \\
\hline Innovación y desarrollo & Se mantiene & $\begin{array}{l}\text { Tecnología de } \\
\text { punta }\end{array}$ & $\begin{array}{l}\text { Tecnología } \\
\text { inaccesible }\end{array}$ \\
\hline \multicolumn{4}{|l|}{ Ecológico } \\
\hline Contaminación & Sin variación & $\begin{array}{l}\text { Baja probabilidad } \\
\text { de ocurrencia }\end{array}$ & $\begin{array}{l}\text { Alta probabilidad } \\
\text { de ocurrencia }\end{array}$ \\
\hline Seguridad e higiene laboral & Sin variación & $\begin{array}{l}\text { Baja probabilidad } \\
\text { de ocurrencia }\end{array}$ & $\begin{array}{l}\text { Alta probabilidad } \\
\text { de ocurrencia }\end{array}$ \\
\hline
\end{tabular}

- Escenario I (Más probable): El entorno político podría tener mayor estabilidad si se dan cambios coyunturales que apoyan a las pymes en temas de gestión. Si el PBI mantiene la proyección de crecimiento mundial de 3,8 por ciento para el presente año y de 3,7 por ciento para 2019, consistente con un menor estímulo monetario en las economías desarrolladas y la convergencia de su crecimiento hacia su potencial. Expertos de Adex señalaron que de seguir apoyando los esfuerzos para levantar las restricciones de acceso a otros mercados y propiciar mejoras de competitividad en los demás subsectores no tradicionales, se podría seguir proponiendo más exportaciones, lo que sería positivo debido al incremento de patrones de consumo. La industria joyera al estar en crecimiento, muchos artesanos están siendo empleados como también las personas naturales con negocios pequeños podrán incursionar en la venta de joyas. Si bien la tecnología 
con la que se trabaja en el Perú es cara, las organizaciones ya se están implementando con técnicas que los ayude a trabajar piezas con mayor performance y perfecto acabado.

Tabla 40

Definición de Escenarios

\begin{tabular}{|c|c|c|}
\hline \multirow[b]{2}{*}{ Análisis del Entorno } & \multicolumn{2}{|c|}{ Escenarios } \\
\hline & $\begin{array}{c}\text { Escenario I } \\
\text { (Más probable) }\end{array}$ & $\begin{array}{c}\text { Escenario II } \\
\text { (Menos probable) }\end{array}$ \\
\hline \multicolumn{3}{|l|}{ Político } \\
\hline Gobernabilidad política & Mayor estabilidad política & $\begin{array}{l}\text { Incremento de incertidumbre } \\
\text { política }\end{array}$ \\
\hline \multicolumn{3}{|r|}{ Pomica } \\
\hline PBI & Alto $>4 \%$ & Bajo $<3 \%$ \\
\hline Factores de importaciones y & Importación >9.7\% & Importación $<9.7 \%$ \\
\hline exportaciones & Exportación > 17.4\% & Exportación $<17.4 \%$ \\
\hline Patrones de consumo & Incremento de consumo & Desaceleración de consumo \\
\hline Mercado comercial & Alto crecimiento & Desacelera \\
\hline Inflación & Se reduce & Se incrementa \\
\hline Impuestos & Se reduce & Se incrementa \\
\hline Empleo & Crece empleo & Crece desempleo \\
\hline \multicolumn{3}{|l|}{ Legal } \\
\hline Legislación & Política de apertura & Política restrictiva \\
\hline Certificación & Alto acceso & Acceso limitado \\
\hline \multicolumn{3}{|l|}{ Cultural } \\
\hline Estilo de vida & Mejora & Acceso limitado \\
\hline \multicolumn{3}{|l|}{ Tecnológico } \\
\hline Innovación y desarrollo & Tecnología de punta & Tecnología inaccesible \\
\hline \multicolumn{3}{|l|}{ Ecológico } \\
\hline Contaminación & Existe probabilidad de ocurrencia & Alta probabilidad de ocurrencia \\
\hline Seguridad e higiene laboral & Baja probabilidad de ocurrencia & Alta probabilidad de ocurrencia \\
\hline
\end{tabular}

Escenario II (Menos probable): Es importante indicar que el Perú actualmente no vive la mejor estabilidad política, hay empresas que tienen incertidumbre si pueden o no seguir invirtiendo, tal como lo señalan en las entrevistas en profundidad, algunas empresas formales se han des constituido para seguir en la informal pues no encuentran mayores oportunidades, pero aun así continúan operando. Las probabilidades de que el PBI baje es posible dependerá del gobierno, clima, pues es la producción del país. Y esto afectaría considerablemente la economía del país, pues no habría empleo, posiblemente los impuestos suban debido a la inestabilidad económica. Existirían políticas más restrictivas que eviten las certificaciones a las pymes o quizá su acceso sea más limitado. Acceder a tecnología para crecer en la producción podría escasear o ser cara, imposible de pagar para muchos quizá. Por otro lado, las minerías informales 
podrían aparecer con más fuerza logrando más contaminación ambiental, auditiva y de procesos mal establecidos cayendo en el Greenwashing ${ }^{11}$

\subsubsection{Comparación de estrategias con escenarios.}

Con los escenarios analizados en el capítulo anterior se procede a comparar las estrategias propuestas para Incas Jewelry SAC con los escenarios probables o menos probables y ver de qué manera favorecen o no a las estrategias intensivas, diversificación o defensivas (ver Tabla 41). Los resultados muestran que en el escenario 1 (más probable) la aplicación de las estrategias: Penetración de mercado, desarrollo de producto, desarrollo de mercado, y liquidación son favorables en el escenario 1 debido a mayor estabilidad en el gobierno, incremento del consumo en compras de joyas y se muestra un alto crecimiento comercial. Y en el escenario 2 es poco favorable al no contar con tecnología que permita ayudar en la industria de la joyería y la probable desaceleración del mercado comercial que no permitiría ingresos a las empresas.

\section{Tabla 41}

Impactos en las Estrategias

\begin{tabular}{|c|c|c|}
\hline & & Escenarios \\
\hline Estrategias & $\begin{array}{l}\text { Escenario I } \\
\text { (Más probable) }\end{array}$ & $\begin{array}{l}\text { Escenario II } \\
\text { (Menos probable) }\end{array}$ \\
\hline Penetración de mercado & Altamente favorable & Poco favorable \\
\hline Desarrollo de producto & Altamente Favorable & Favorable \\
\hline Desarrollo de mercado & Favorable & Poco favorable \\
\hline Desinversión & Poco favorable & Favorable \\
\hline Liquidación & Favorable & Favorable \\
\hline
\end{tabular}

\subsection{Matriz de Planeación Estratégica Cuantitativa MPEC}

En 2015, David señaló "La MCPE determina el atractivo relativo de las diferentes estrategias a partir del grado en que los factores internos y externos críticos para el éxito son aprovechados o mejorados. Se pueden incluir cualquier número de estrategias alternativas, y cualquier cantidad de estrategias pueden conformar un conjunto dado, pero sólo las estrategias de cada conjunto se evalúan tomando en cuenta la relación entre ellas".

Se pasa a detallar los pasos para la construcción de la matriz MPEC, sugeridas por el autor:

\footnotetext{
${ }^{11}$ Greenwashing: Ecoblanqueamiento, lavado verde. Propaganda en el que se realiza propaganda para promover marketing verde de un producto que no respeta al medio ambiente con el fin de aumentar sus beneficios.
} 
- Paso 1: Listar las oportunidades/amenazas externas y de las fortalezas/debilidades internas clave en la columna izquierda de la MCPE. Esta información debe tomarse directamente de las matrices EFE (Capitulo 4.5) y EFI (Capitulo 6.6). La MCPE debe incluir un mínimo de 10 factores externos y 10 factores internos clave para el éxito.

- Paso 2: Asignar una ponderación a cada uno de los factores internos y externos clave. Estas ponderaciones son idénticas a las de las matrices EFE y EFI, y se presentan en una columna justo a la derecha de los factores internos clave.

- Paso 3: Examinar las matrices (de adecuación) creadas de la etapa 2, e identificar las estrategias alternativas cuya implementación debe considerar la organización. Registre estas estrategias en la fila superior de la MCPE. De ser posible, agrupe estas estrategias en conjuntos mutuamente excluyentes.

- Paso 4: Determinar el puntaje de atractividad (PA), es decir, un valor numérico que indique el atractivo relativo de cada una de las estrategias que conforman un conjunto específico de alternativas. El puntaje de atractivo (PA) se determina examinando uno a uno los factores internos o externos con base en esta pregunta: “¿Este factor afecta la elección de estrategias realizada?”. Si la respuesta es positiva, las estrategias deben compararse en relación con ese factor clave. Este puntaje debe asignarse específicamente a cada estrategia para indicar su atractivo relativo sobre las demás en lo que respecta al factor clave que se esté analizando. El rango del puntaje de atractivo es $1=$ no atractivo, $2=$ algo atractivo, $3=$ razonablemente atractivo, y 4 = altamente atractivo. Por atractivo queremos decir el grado en que una estrategia permite, en comparación con las demás, que la empresa capitalice sus fortalezas, supere sus debilidades, aproveche la oportunidad o evite la amenaza. Al desarrollar la MCPE es recomendable trabajar fila por fila. Si la respuesta a la pregunta anterior es negativa - lo cual indica que el factor clave en cuestión no afecta la elección específica realizada - , no asigne puntajes de atractivo a las estrategias de ese conjunto; en lugar de ello utilice un guion para indicar que el factor clave no afecta la elección. Nota: si asigna un PA a una estrategia, haga lo propio con las demás. En otras palabras, si desde su punto de vista una de las estrategias de un conjunto en particular no tiene efecto sobre la elección (y por lo tanto, recibe un guion), todas las demás de ese conjunto deben calificarse igual. 
- Paso 5: Calcular la calificación del atractivo. La calificación del atractivo (CA) se define como el resultado de multiplicar las ponderaciones (paso 2) por el puntaje de atractivo (paso 4) de cada fila. La calificación del atractivo indica el atractivo relativo de cada estrategia alternativa, considerando exclusivamente el impacto de los factores internos claves adyacentes. Cuanto mayor sea la CA más atractiva será la alternativa estratégica (considerando sólo el factor clave adyacente).

- Paso 6: Obtener la calificación total del atractivo. Sume las calificaciones del atractivo de cada columna de estrategia de la MCPE. La calificación total del atractivo (CTA) indica cuál es la estrategia más atractiva en un conjunto de alternativas. Los puntajes más altos indican las estrategias más atractivas, considerando todos los factores internos y externos relevantes que pudieran afectar las decisiones estratégicas. La magnitud de la diferencia que haya entre las calificaciones totales del atractivo en un conjunto determinado de alternativas estratégicas indica la superioridad de una estrategia respecto de las demás.

En la Tabla 42 se muestran las estrategias según su ponderación de atractivo (PA) y Calificación de Atractivo (CA), las cuales fueron resumidas en la tabla 43 en el orden de CA.

\subsection{Descripción de Estrategia Seleccionada}

De la ponderación realizada en la matriz MPEC se eligió la estrategia de mayor CA, siendo 6.08 siendo la Estrategia de Penetración de Mercado, con lo que se procede a describir actividades de las estrategias seleccionadas (ver Tabla 44). Para ello se determinó que en esta estrategia las oportunidades y fortalezas en su mayoría son altamente atractivas, como por ejemplo la existencia de los TLC que permitirá exportar parte de la producción de la tienda, la demanda de compradores locales y su preferencia por adquirir joyas de valor, existencia de mano de obra calificada que permite entregar un trabajo de calidad, entre otros. 
Tabla 42

MPEC para Incas Jewelry SAC

\section{MPEC}

\begin{tabular}{|c|c|c|c|c|c|c|}
\hline 艺 & $\begin{array}{l}\text { Estrategia de } \\
\text { Penetración de } \\
\text { Mercado }\end{array}$ & $\begin{array}{l}\text { Estrategia } \\
\text { de } \\
\text { desarrollo } \\
\text { de } \\
\text { mercado }\end{array}$ & $\begin{array}{l}\text { Estrategia } \\
\text { de } \\
\text { desarrollo } \\
\text { de producto }\end{array}$ & $\begin{array}{l}\text { Estrategia de } \\
\text { liquidación }\end{array}$ & $\begin{array}{l}\text { Estrategia de } \\
\text { diversificaci } \\
\text { ón } \\
\text { relacionada }\end{array}$ & $\begin{array}{l}\text { Estrategia de } \\
\text { recorte de } \\
\text { gasto }\end{array}$ \\
\hline そ) & $\begin{array}{l}\text { Búsqueda del } \\
\text { aumento de la } \\
\text { participación } \\
\text { en el mercado. }\end{array}$ & $\begin{array}{l}\text { Globalizac } \\
\text { ión de la } \\
\text { empresa en } \\
\text { ferias } \\
\text { locales. }\end{array}$ & $\begin{array}{l}\text { Buscar } \\
\text { liderar el } \\
\text { mercado } \\
\text { mediante } \\
\text { certificacion } \\
\text { es. }\end{array}$ & $\begin{array}{l}\text { Vender } \\
\text { activos que } \\
\text { generan } \\
\text { perdida a su } \\
\text { valor } \\
\text { tangible. }\end{array}$ & $\begin{array}{l}\text { Producir } \\
\text { productos } \\
\text { relacionada } \\
\text { con el actual }\end{array}$ & $\begin{array}{l}\text { Reducción } \\
\text { de costos }\end{array}$ \\
\hline
\end{tabular}

\begin{tabular}{|c|c|c|c|c|c|c|c|c|c|c|c|c|c|}
\hline \multirow{2}{*}{\multicolumn{2}{|c|}{ Oportunidades }} & \multirow{3}{*}{$\frac{\text { PA }}{4}$} & \multirow{3}{*}{$\begin{array}{c}\mathrm{CA} \\
0.32\end{array}$} & \multirow{3}{*}{$\begin{array}{c}\text { PA } \\
-\end{array}$} & \multirow{3}{*}{$\begin{array}{c}\mathrm{CA} \\
-\end{array}$} & \multirow{3}{*}{$\begin{array}{c}\text { PA } \\
3\end{array}$} & \multirow{3}{*}{\begin{tabular}{c|c}
$\mathrm{CA}$ \\
0.24
\end{tabular}} & \multirow{2}{*}{ PA } & \multirow{2}{*}{$\mathrm{CA}$} & \multirow{2}{*}{ PA } & \multirow{2}{*}{$\mathrm{CA}$} & \multirow{2}{*}{ PA } & \multirow{3}{*}{$\begin{array}{cc}\mathrm{CA} \\
-\end{array}$} \\
\hline & & & & & & & & & & & & & \\
\hline $\begin{array}{l}\text { O1. Existencia de TLC con países con alto potencial de } \\
\text { compradores y proveedores }\end{array}$ & 0.08 & & & & & & & - & - & - & - & - & \\
\hline O2. Alta demanda de compradores de joyas de plata & 0.08 & 4 & 0.32 & 2 & 0.16 & 3 & 0.24 & - & - & - & - & - & - \\
\hline O3. Existencia de importadores de Europa y Asia & 0.03 & 4 & 0.12 & 2 & 0.06 & 3 & 0.09 & - & - & - & - & - & - \\
\hline O4. Alto poder adquisitivo de clientes extranjeros & 0.03 & 4 & 0.12 & 2 & 0.06 & 3 & 0.09 & - & - & - & - & - & - \\
\hline O5. Existencia de ferias & 0.03 & 2 & 0.06 & 4 & 0.12 & 3 & 0.09 & - & - & - & - & - & - \\
\hline O6. Potencial de las redes sociales para comercializar productos & 0.03 & 3 & 0.09 & 1 & 0.03 & 2 & 0.06 & - & - & - & - & - & - \\
\hline \multirow[t]{2}{*}{$\begin{array}{l}\text { O7. Posicionamiento de los diseños étnicos peruanos a nivel } \\
\text { mundial }\end{array}$} & 0.06 & 3 & 0.18 & - & - & 4 & 0.24 & - & - & - & - & - & - \\
\hline & & & & & & & & & & & & & \\
\hline A1. Presencia de mayoristas & 0.08 & 4 & 0.32 & 2 & 0.16 & 3 & 0.24 & - & - & - & - & 1 & 0.08 \\
\hline A2. Existencia de productos sustitutos & 0.06 & 4 & 0.24 & 2 & 0.12 & 3 & 0.18 & - & - & 1 & 0.06 & - & - \\
\hline A3. Economía de escala de las grandes tiendas & 0.08 & 3 & 0.24 & - & - & - & - & - & - & 2 & 0.16 & - & - \\
\hline A4. Alza de precio de los insumos & 0.06 & 2 & 0.12 & 4 & 0.24 & - & - & - & - & 3 & 0.18 & 1 & 0.06 \\
\hline A5. Limitado apoyo de la cámara de comercio & 0.06 & 3 & 0.18 & - & - & - & - & - & - & 4 & 0.24 & 2 & 0.12 \\
\hline A6. Alta informalidad en el sector & 0.10 & 2 & 0.20 & 1 & 0.10 & 4 & 0.40 & - & - & - & - & 3 & 0.30 \\
\hline A7. Presencia de grandes marcas & 0.08 & 2 & 0.16 & - & - & - & - & 4 & 0.32 & 3 & 0.24 & 1 & 0.08 \\
\hline A8. Existencia de empresas virtuales & 0.06 & 4 & 0.24 & - & - & 3 & - & - & - & - & - & - & - \\
\hline A9. Piratería de diseños & 0.08 & 3 & 0.24 & 1 & 0.08 & 2 & 0.16 & - & - & 4 & 0.32 & - & - \\
\hline
\end{tabular}




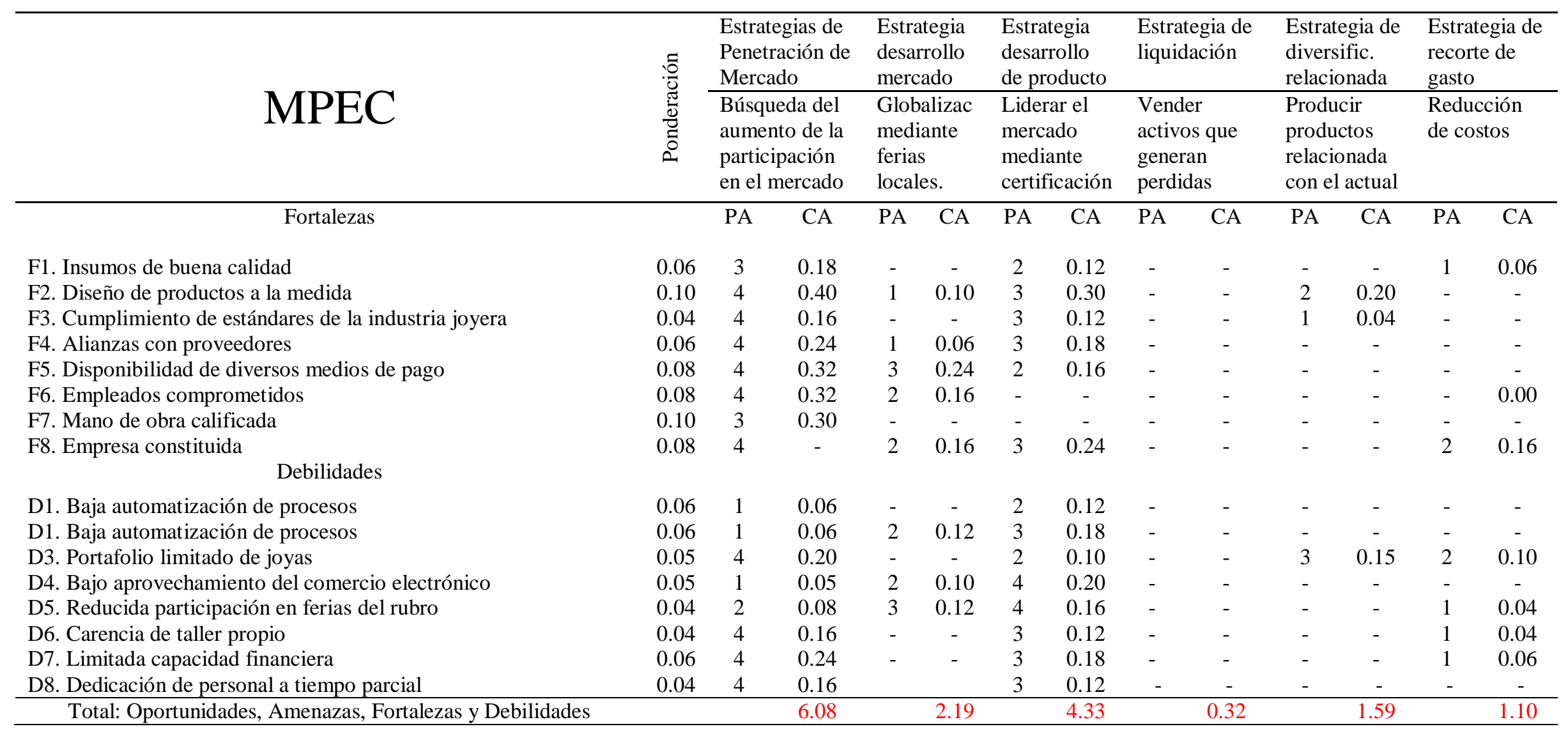

Nota. Tomado de Conceptos de Administración Estrategica (p. 363), por F. David, 2013, México, DF., México: Prentice Hall Copyright 2013 por Pearson Education 
Tabla 43

Resumen de Estrategias y su CA

\begin{tabular}{llc}
\hline \multicolumn{1}{c}{ Estrategia } & CA \\
\hline 1. & $\begin{array}{l}\text { Estrategia de penetración de mercado para buscar el aumento de la participación } \\
\text { en el mercado }\end{array}$ & 6.08 \\
2. $\begin{array}{l}\text { Estrategia de desarrollo de producto, buscar liderar el mercado mediante } \\
\text { certificaciones. }\end{array}$ & 4.33 \\
3. $\begin{array}{l}\text { Estrategia de desarrollo de mercado para buscar la globalización de la empresa en } \\
\text { ferias locales. }\end{array}$ & 2.19 \\
4. & $\begin{array}{l}\text { Estrategia de diversificación relacionada agregando productos relacionada con el } \\
\text { actual }\end{array}$ & 1.59 \\
5. $\begin{array}{l}\text { Estrategia de recorte de gastos a través de la reducción de costos } \\
\text { 6. }\end{array}$ & 0.32 \\
& tangible.
\end{tabular}

Nota. Tomado de Proceso Estratégico (p.115), por F. D’Alessio, 2015, Lima, Perú: Pearson 2013 por Pearson Educación de Perú S.A.

\section{Tabla 44}

Descripción de la Estrategia Propuesta para Incas Jewelry SAC

\section{Estrategia de Penetración de mercado}

Aumentar los canales de distribución y medios digitales:

Buscar tiendas o establecimientos para que vendan los productos en sus propios puntos de venta y con la posibilidad de generar algún ingreso por comisión de venta. Como intención adoptar la venta de los productos desde sus propias redes sociales.

Desarrollar alianzas entre empresas locales y nacionales para bajar costos y asumir riesgos conjuntos entregando portafolio de productos.

Definir los dos grandes grupos de clientes del negocio que son los extranjeros que compran una sola vez cuyo ticket de compra debe ser lo más alto posible y los nacionales que deben ser fidelizados.

Definir procesos de producción que permitan responder a pedidos de volúmenes mayores.

Aplicar la Transformación Digital al negocio y ejecutar todos los procesos del negocio con el uso de la tecnología.

Establecer un modelo de rentabilidad de productos que justifique la producción personalizada de un pedido. Aprovechando la gran oferta de artesanos que trabajan diseños étnicos se pueden encontrar piezas con bajos niveles de costo que permitan generar rentabilidad en la venta.

Realizar alianzas con diseñadores y artesanos conocidos para la creación de diseños nuevos y exclusivos con motivos étnicos andinos.

Promocionar los diversos medios de pago:

A través de los medios digitales y en tienda informar en campañas publicitarias a los clientes de las

diversas formas de pago que se disponen para la venta de los productos

Ajustar precios:

Con el conocimiento que se tiene de los productos provenientes de Asia y Europa la empresa se puede proveer de insumos de costo menor que ayuden a mejorar la rentabilidad de la empresa.

Incrementar la importación de productos semielaborados de países productores con mejores precios.

En vista que se tiene definido los dos grandes grupos de clientes, mejorar el empaque de los productos.

Prepara un empaque que tenga atributos de pertenencia a la tienda para dos tipos de clientes. A) Jóvenes y

Adultos. B) Nacionales y extranjeros

Nota. Tomado de Conceptos de Administración Estratégica (p. 369), por F. David, 2013, México, D.F., México: Prentice Hall. Copyrigth 2013 por Pearson Education.

\subsection{Descripción de Estrategia Contingente}

De la ponderación del MPEC, resultó que la Estrategia de Desarrollo de Producto es aquella con segundo menor puntaje alcanzando 4.33 encontrándose que las oportunidades y 
fortalezas son altamente atractivas, como por ejemplo tener empleados comprometidos es atractivo, factor necesario para desarrollar un producto, tener alianzas con los proveedores asegura entregas en el tiempo requerido para la producción de joyas y la posición de los diseños étnicos en el mercado local también lo hace atractivo, es por ello que se procede a describir las contingencias de la estrategia seleccionada (ver Tabla 45).

\section{Tabla 45}

Descripción de Estrategia Contingentes Propuestas para Incas Jewelry SAC

\section{Estrategia Desarrollo de producto:}

Buscar liderar el mercado mediante certificaciones.

Obtener las certificaciones de las piezas obtenidas por medio del insumo comprado de primera fuente.

Obtener retroalimentación de parte de los clientes:

Entregar pequeñas encuestas a los clientes que visiten la tienda para que entreguen un feedback que permitan mejorar el modelo de negocio de la tienda y también aprovechar el fanpage para generar recomendaciones positivas por parte de clientes satisfechos.

Nota. Tomado de Conceptos de Administración Estratégica (p. 369), por F. David, 2013, México, D.F., México: Prentice Hall. Copyrigth 2013 por Pearson Education. 


\section{Capítulo IX: Implantación de la Estrategia}

En este capítulo se procede a realizar el mapa de la estrategia, con sus respectivos objetivos específicos, indicadores, metas, iniciativas, responsables, presupuesto y cronograma. Para un mejor entendimiento se muestra todo el mapa completo al final del subcapítulo 9.8 .

\subsection{Mapa de la Estrategia}

Un mapa estratégico es una completa representación visual de la estrategia de una organización, describe el proceso de creación de valor mediante una serie de relaciones de causa y efecto entre los objetivos de las cuatro perspectivas del BSC.

En este sentido, Kaplan y Norton (1992) señalaron "EL BSC es un modelo de gestión que permite a las organizaciones contar con una visión general, conjunta e interrelacionada de los distintos objetivos de la empresa. El BSC o CMI se apoya en diversos indicadores que permiten vincular los objetivos de la empresa con planes de acción concretos. Mediante los indicadores, el BSC puede controlar y monitorear tanto los objetivos de las empresas como las diferentes áreas de negocio."

En el siguiente mapa estratégico mostramos la distribución de estrategias según las perspectivas financiera, cliente, proceso interno y aprendizaje (ver Figura 19):

- Perspectiva Financiera: Describe los resultados tangibles de la estrategia utilizando indicadores conocidos, como el retorno sobre la inversión, el valor agregado económico, las ganancias operativas, la inversión, el valor agregado económico, entre otros.

- Perspectiva Clientes: Comprende los indicadores relativos a la satisfacción del cliente, la retención y el crecimiento. Su propuesta de valor será el eje de la estrategia que describirá como se diferencia la compañía a los ojos del cliente.

- Perspectiva Procesos Internos: Identifica claramente los procesos clave, (desde pagar los salarios y publicar los estados financieros trimestrales hasta mantener los equipos y las instalaciones e incluso, inventar productos nuevos) de modo que los gerentes y los empleados puedan focalizarse en mejorarlos de forma constante.

- Perspectiva Aprendizaje y Crecimiento: Identifica los puestos de trabajo (capital humano), los sistemas (capital de información), y el clima (capital organizacional) que sustentan los procesos que crean valor. Con los datos analizados se procede a elaborar el mapa estratégico (ver Figura 20). 
Rentabilidad

\begin{tabular}{|c|c|c|c|c|c|}
\hline \multirow{2}{*}{$\begin{array}{c}\text { ¿Qué quiero } \\
\text { obtener? } \\
\Delta \\
\text { ¿Qué debo } \\
\text { ofrecer? } \\
\boldsymbol{\Delta}\end{array}$} & \multirow{2}{*}{ 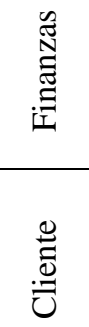 } & Estrategi & crecimiento & \multicolumn{2}{|c|}{ Estrategia de productividad } \\
\hline & & \multicolumn{4}{|c|}{$\uparrow$ Propuesta Única de Valor $\uparrow$} \\
\hline $\begin{array}{l}\text { ¿Qué debo } \\
\text { hacer? }\end{array}$ & 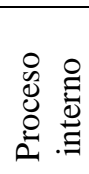 & $\begin{array}{c}\uparrow \\
\text { Operación }\end{array}$ & $\begin{array}{c}\uparrow \uparrow \\
\text { Relación con el } \\
\text { Cliente }\end{array}$ & $\begin{array}{c}\uparrow \\
\text { Innovación }\end{array}$ & $\begin{array}{c}\uparrow \\
\text { Regulación y } \\
\text { resp. Social }\end{array}$ \\
\hline $\begin{array}{c}\text { ¿Qué debo } \\
\text { tener? } \\
\boldsymbol{\Delta}\end{array}$ & 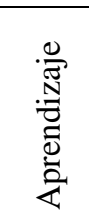 & & $\begin{aligned} & . \uparrow \text { Capital } 1 \\
& \uparrow \text { Capital de } \\
& \uparrow \text { Capital de o }\end{aligned}$ & $\begin{array}{l}\text { Imano } \uparrow 5 \\
\text { formación } \uparrow \\
\text { ganización } \uparrow\end{array}$ & \\
\hline
\end{tabular}

Figura 19. Mapa Estratégico. Tomado de Balance Scorecard (p. 161), por R. Kaplan y D. Norton, 2000, España: Harvard School Publishing Corporation. Copyright 2000 por Gestión 2000 .

\subsection{Objetivos Específicos según el Mapa de la Estrategia}

La organización debe de definir los objetivos que busca lograr en cada uno de los temas estratégicos. Estos objetivos deben reflejar tanto la perspectiva en la que se encuentran como el tenor del tema estratégico al que pertenecen. Asimismo, se debe tener cuidado de redactarlos de manera muy clara y de unificar los conceptos que se utilizan en cada uno de ellos para que cualquier persona de la empresa pueda verlos y comprender cómo se planea lograr la estrategia. (Kaplan \& Norton, 1992) (p.114)

Los objetivos financieros reflejan lo que los accionistas esperan de la organización. Entre ellos se puede encontrar: maximizar el valor de los accionistas, incrementar la rentabilidad de la operación, optimizar el manejo de los activos, etc. Los objetivos de clientes y mercado buscan representar las metas de la organización en cuanto al mercado al que atienden. Asimismo, se recomienda mencionar los atributos de valor para el cliente que diferencian a la organización de sus competidores. Los objetivos de procesos internos van muy ligados a la cadena de valor de cada organización, así como a los temas estratégicos que elijan para representar su estrategia corporativa. Los directores deben asegurarse que los 


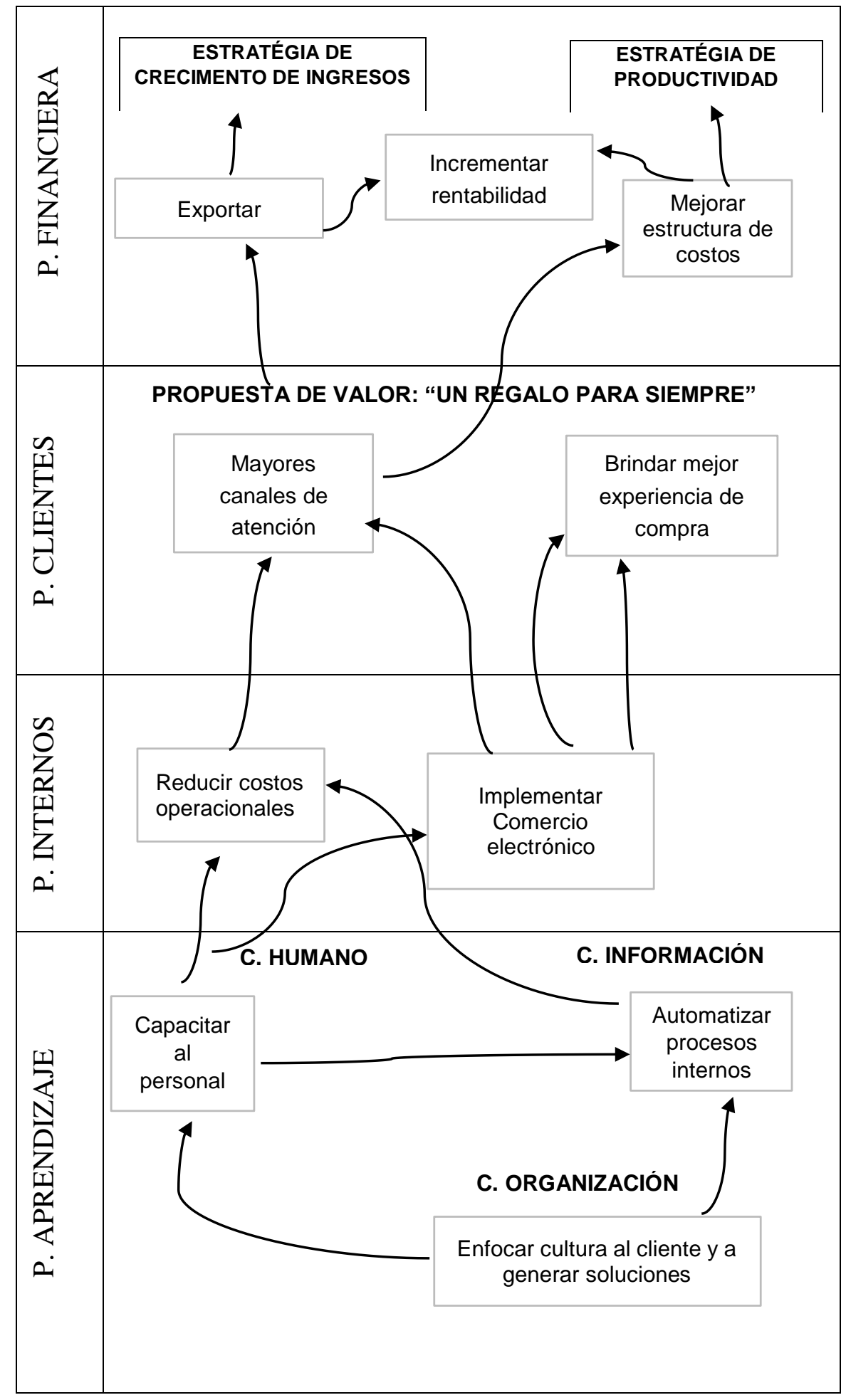

Figura 20. Mapa Estratégico de Incas Jewelry. Tomado de Balance Scorecard (p. 181), por R. Kaplan y D. 1Norton, 2000, España: Harvard School Publishing Corporation. Copyright 2000 por Gestión 2000.

procesos más estratégicamente relevantes se encuentren debidamente representados en esta categoría. 
Los objetivos de aprendizaje y crecimiento se pueden encontrar: contar con personal capacitado y motivado, ofrecer condiciones competitivas de trabajo, contar con infraestructura tecnológica de vanguardia, hacer la estrategia el trabajo de todos, etc. Los objetivos específicos deben tener ser SMART (metodología inteligente), es decir, poner énfasis en el resultado final de una situación. Estos objetivos siguen los siguientes lineamientos: (a). Específico: ¿Se define exactamente qué es lo que está siendo perseguido?; (b). Medible: ¿Existe un número que describe el objetivo completo?; (c). Alcanzable: ¿Puede ser el objetivo logrado?; (d). Realista: ¿Con qué vas a conseguir ese objetivo?; (e). A tiempo: ¿Cuánto tiempo crees que te va a llevar cumplir ese objetivo?

Para un mejor entendimiento se detalla a continuación los objetivos estratégicos con sus respectivos objetivos específicos (ver Tabla 46).

\section{Tabla 46}

Objetivos Específicos de Incas Jewelry SAC

\begin{tabular}{|c|c|c|}
\hline & Objetivos estratégicos & Objetivos específicos \\
\hline \multirow{2}{*}{ 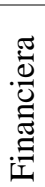 } & Hacer la empresa rentable al 2022 & Aumentar la utilidad neta del negocio \\
\hline & $\begin{array}{l}\text { Lograr que un } 15 \% \text { de las ventas totales } \\
\text { anuales al } 2022 \text { sean al exterior }\end{array}$ & Incrementar la exportación en el orden de $3 \%$ anual \\
\hline \multirow{2}{*}{ 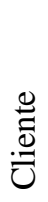 } & $\begin{array}{l}\text { Aumentar en } 15 \% \text { los canales de atención al } \\
2022\end{array}$ & Aperturar nuevos canales de atención en $15 \%$ al 2022 \\
\hline & $\begin{array}{l}\text { Mejorar la experiencia de compra en un } 85 \% \\
\text { al } 2022\end{array}$ & $\begin{array}{l}\text { Mejorar la calidad del servicio postventa en un } 10 \% \text { al } \\
2022\end{array}$ \\
\hline \multirow{5}{*}{ 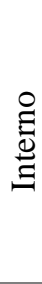 } & $\begin{array}{l}\text { Reducir un } 15 \% \text { los costos en compras a } \\
\text { proveedores al } 2022\end{array}$ & Reducir los costos de un producto un $5 \%$ \\
\hline & Lograr que un $20 \%$ de las ventas totales & Implementar plataforma de e-commerce al 2019 \\
\hline & & Lograr un $10 \%$ de ventas por e-commerce al 2020 \\
\hline & & $\operatorname{Al} 202115 \%$ \\
\hline & & Al $202220 \%$ \\
\hline 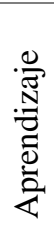 & $\begin{array}{l}\text { Lograr que el } 100 \% \text { del personal haya } \\
\text { recibido una capacitación al } 2022\end{array}$ & Capacitar al $100 \%$ a todas las áreas al 2022 \\
\hline
\end{tabular}

Nota. Adaptado de The Balance Scorecard (p. 161), por R. Kaplan y D. Norton, 2000, España: Harvard Business School. Copyrigth 2000 por Gestión 2000. 


\subsection{Indicadores para cada uno de los Objetivos Específicos}

El Balanced Scorecard (BSC) es una herramienta que permite implementar la estrategia y la misión de una empresa, ha sido incorporada a los procesos de gerencia estratégica de las pequeñas y grandes organizaciones. Estos indicadores son una parte importante de un BSC pues ayuda a que los objetivos de la empresa puedan ser controlados y monitorear las diversas áreas de la empresa. Los autores presentan tres clases de indicadores. (Kaplan \& Norton, 1992):

Indicadores de productividad, tiene que ver con la calidad del proceso:

- Calidad del producto.

- Coste del producto.

- Eficiencia del proceso de fabricación.

- Tiempos de entrega.

- Indicadores de seguridad e higiene.

- Calidad de materias primas.

- Repetitividad de los procesos.

- Mantenimiento de productos.

- Indicadores medioambientales.

Indicadores de perspectiva del cliente, tiene que ver la satisfacción de los clientes:

- Fidelidad del cliente.

- Satisfacción del cliente.

- Calidad percibida de nuestro producto o servicio.

- Imagen que tienen los clientes de nosotros.

- Calidad del servicio postventa y de atención al cliente.

Indicadores de perspectiva financiera, tiene que ver la situación económica de la empresa:

- Ampliaciones de capital.

- Gestión del riesgo.

- Indicadores de ventas.

- Indicadores de liquidez.

- Nivel de endeudamiento.

Estos indicadores tienen que ser cuantificables. Para poder explicar los objetivos específicos, se procede a colocar las estrategias del mapa clasificándolos en el orden de cada perspectiva (ver Tabla 47). 
Tabla 47

Indicadores P. Financiera, Clientes, Procesos Internos y Aprendizaje

\begin{tabular}{|c|c|c|c|}
\hline & Objetivos estratégicos & Objetivos específicos & Indicadores \\
\hline \multirow{2}{*}{ 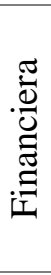 } & $\begin{array}{l}\text { Hacer la empresa rentable al } \\
2022\end{array}$ & Aumentar la utilidad neta del negocio & $\%$ Margen Neto \\
\hline & $\begin{array}{l}\text { Lograr que un } 15 \% \text { de las } \\
\text { ventas totales anuales al } 2022 \\
\text { sean al exterior }\end{array}$ & Incrementar la exportación en el orden de $3 \%$ anual & Montos de ventas al exterior / Ventas totales \\
\hline \multirow{2}{*}{ 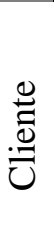 } & $\begin{array}{l}\text { Aumentar en } 15 \% \text { los canales } \\
\text { de atención al } 2022\end{array}$ & $\begin{array}{l}\text { Aperturar nuevos canales de atención en } 15 \% \text { al } \\
2022\end{array}$ & $\begin{array}{l}\text { Cantidad de canales de atención del año actual / Cantidad de } \\
\text { canales de atención del año anterior }\end{array}$ \\
\hline & $\begin{array}{l}\text { Mejorar la experiencia de } \\
\text { compra en un } 85 \% \text { al } 2022\end{array}$ & $\begin{array}{l}\text { Mejorar la calidad del servicio postventa en un } 10 \% \\
\text { al } 2022\end{array}$ & \% Satisfacción de clientes \\
\hline \multirow{3}{*}{$\stackrel{\text { : }}{\stackrel{0}{\Xi}}$} & $\begin{array}{l}\text { Reducir un } 15 \% \text { los costos en } \\
\text { compras a proveedores al } 2022\end{array}$ & Reducir los costos de un producto un $5 \%$ & $\begin{array}{l}\text { Inversión de las compras del año anterior/ Inversión de las } \\
\text { compras del año actual }\end{array}$ \\
\hline & $\begin{array}{l}\text { Lograr que un } 20 \% \text { de las } \\
\text { ventas totales anuales al } 2022\end{array}$ & Implementar plataforma de e-commerce al 2019 & $\%$ Avance \\
\hline & sean por medios digitales & $\begin{array}{l}\text { Lograr un } 10 \% \text { de ventas por e-commerce al } 2020 \\
\text { Al } 202115 \% \\
\text { Al } 202220 \%\end{array}$ & $\begin{array}{l}\text { Cantidad de clientes compran por e-commerce del año actual } \\
\text { / Cantidad de clientes compran por e-commerce del año } \\
\text { anterior }\end{array}$ \\
\hline 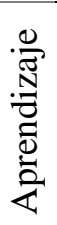 & $\begin{array}{l}\text { Lograr que el } 100 \% \text { del } \\
\text { personal haya recibido una } \\
\text { capacitación al } 2022\end{array}$ & Capacitar al $100 \%$ a todas las áreas al 2022 & $\%$ personas capacitadas \\
\hline
\end{tabular}

Nota. Adaptado de The Balance Scorecard (p. 161), por R. Kaplan y D. Norton, 2000, España: Harvard Business School. Copyrigth 2000 por Gestión 2000. 


\subsection{Metas para cada uno de los Objetivos Específicos}

Las metas financieras se fijan considerando información externa del mercado. Generalmente, una empresa debería apuntar a ser primera o segunda de su industria en crecimiento de ingresos, productividad y otros indicadores financieros fundamentales. Las metas de alto nivel también deberían incluir métricas relacionadas con los clientes, como la participación de mercado. (Kaplan \& Norton, 1992) (p.77). Las metas deben ser alcanzables para evitar que los gerentes se desalienten por las estrategias no alcanzadas o no viables. Las metas organizacionales según el BSC se definen de la siguiente forma:

- Concepción estratégica: En esta fase incluye la misión, visión, desafíos, oportunidades, la orientación estratégica de la empresa, y el plan del proyecto.

- Objetivos y medidas estratégicas: Se incluye los objetivos estratégicos, los indicadores estratégicos, vectores estratégicos y modelo causa y efecto preliminar.

- Metas e iniciativas: Incluye los objetivos detallados, modelo causa y efecto, indicadores estratégicos, metas por indicador, e iniciativas estratégicas.

- Comunicación y sistematización: En esta última fase se incluye la divulgación, planes de acción, agenda gerencial, plan de alineación de iniciativas, objetivos estratégicos y plan de despliegue de toda la empresa.

Las metas trazadas en la tabla adjuntas fueron colocadas según cada objetivo específico según la estrategia seleccionada (ver Tabla 48).

\subsection{Iniciativas}

En este sentido, Kaplan y Norton (1992) señalaron que las iniciativas se hacen en aquellos proyectos de duración acotada que no se incluyen dentro del trabajo rutinario de la compañía. Estos proyectos están diseñados para ayudar a lograr el desempeño propuesto en la estrategia, se procede a colocar las iniciativas por cada objetivo específico propuesto. Es habitual emplear tres procesos para gestionar las iniciativas estratégicas:

- Selección de iniciativas. Definir el repertorio de iniciativas para cerrar cada una de las brechas de desempeño.

- Financiación de la estrategia. Proporcionar una fuente de financiación para lo estratégico diferente a los recursos destinados a lo operativo.

- Definición de responsabilidades. Aquí se establecen los distintos responsables de cada línea estratégica.

En la tabla 49 se presentan las iniciativas que se deben realizar como parte de las acciones para la ejecución de las estrategias. Estas iniciativas fueron revisadas por el Gerente General y el de Operaciones. 
Tabla 48

Metas de Perspectiva Financiera, Clientes, Procesos Internos y Aprendizaje

\begin{tabular}{|c|c|c|c|c|c|}
\hline & Objetivos estratégicos & Objetivos específicos & Indicadores & Año & Meta \\
\hline 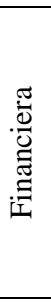 & $\begin{array}{l}\text { Hacer la empresa rentable al } 2022 \\
\text { Lograr que un } 15 \% \text { de las ventas } \\
\text { totales anuales al } 2022 \text { sean al } \\
\text { exterior }\end{array}$ & $\begin{array}{l}\text { Aumentar la utilidad neta del negocio } \\
\text { Incrementar la exportación en el } \\
\text { orden de 3\% anual }\end{array}$ & $\begin{array}{l}\text { Montos de ventas al exterior / Ventas } \\
\text { totales }\end{array}$ & $\begin{array}{l}2019 \\
2020 \\
2021 \\
2022 \\
2019 \\
2020 \\
2021 \\
2022\end{array}$ & $\begin{array}{c}33 \% \\
37 \% \\
52 \% \\
65 \% \\
6 \% \\
9 \% \\
12 \% \\
15 \%\end{array}$ \\
\hline 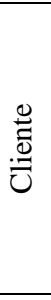 & $\begin{array}{l}\text { Aumentar en } 15 \% \text { los canales de } \\
\text { atención al } 2022 \\
\text { Mejorar la experiencia de compra } \\
\text { en un } 85 \% \text { al } 2022\end{array}$ & $\begin{array}{l}\text { Aperturar nuevos canales de atención } \\
\text { en } 15 \% \text { al } 2022\end{array}$ & $\begin{array}{l}\text { Cantidad de canales de atención del } \\
\text { año actual / Cantidad de canales de } \\
\text { atención del año anterior } \\
\text { \% Satisfacción de clientes }\end{array}$ & $\begin{array}{l}2019 \\
2020 \\
2021 \\
2022 \\
2019 \\
2020 \\
2021 \\
2022 \\
\end{array}$ & $\begin{array}{l}8 \% \\
10 \% \\
12 \% \\
15 \% \\
75 \% \\
78 \% \\
80 \% \\
85 \% \\
\end{array}$ \\
\hline & $\begin{array}{l}\text { Reducir un } 15 \% \text { los costos en } \\
\text { compras a proveedores al } 2022\end{array}$ & $\begin{array}{l}\text { Reducir los costos de un producto un } \\
5 \%\end{array}$ & $\begin{array}{l}\text { Inversión de las compras del año } \\
\text { anterior/ Inversión de las compras del } \\
\text { año actual }\end{array}$ & $\begin{array}{l}2019 \\
2020 \\
2021 \\
2022\end{array}$ & $\begin{array}{l}>40 \% \\
>40 \% \\
>40 \% \\
>40 \%\end{array}$ \\
\hline$\stackrel{8}{\stackrel{0}{0}}$ & $\begin{array}{l}\text { Lograr que un } 20 \% \text { de las ventas } \\
\text { totales anuales al } 2022 \text { sean por } \\
\text { medios digitales }\end{array}$ & $\begin{array}{l}\text { Implementar plataforma de e- } \\
\text { commerce al } 2019 \\
\text { Lograr un } 10 \% \text { de ventas por e- } \\
\text { commerce al } 2020 \\
\text { Al } 202115 \% \\
\text { Al } 202220 \%\end{array}$ & $\begin{array}{l}\% \text { Avance } \\
\text { Cantidad de clientes compran por e- } \\
\text { commerce del año actual / Cantidad } \\
\text { de clientes compran por e-commerce } \\
\text { del año anterior }\end{array}$ & $\begin{array}{l}2019 \\
2020 \\
2021 \\
2022\end{array}$ & $\begin{array}{l}100 \% \\
100 \% \\
5 \% \\
10 \% \\
15 \% \\
20 \%\end{array}$ \\
\hline 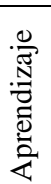 & $\begin{array}{l}\text { Lograr que el } 100 \% \text { del personal } \\
\text { haya recibido una capacitación al } \\
2022\end{array}$ & $\begin{array}{l}\text { Capacitar al } 100 \% \text { a todas las áreas al } \\
2022\end{array}$ & $\%$ personas capacitadas & $\begin{array}{l}2019 \\
2020 \\
2021 \\
2022\end{array}$ & $\begin{array}{l}25 \% \\
50 \% \\
75 \% \\
100 \%\end{array}$ \\
\hline
\end{tabular}

Nota. Adaptado de The Balance Scorecard (p. 161), por R. Kaplan y D. Norton, 2000, España: Harvard Business School. Copyrigth 2000 por Gestión 2000. 
Tabla 49

Iniciativas Perspectiva Financiera, Clientes, Procesos Internos y Aprendizaje

\begin{tabular}{|c|c|c|c|c|c|c|}
\hline & Objetivos estratégicos & Objetivos específicos & Indicadores & Año & Meta & Iniciativa \\
\hline \multirow{8}{*}{ 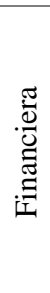 } & Hacer la empresa & Aumentar la utilidad neta del & $\%$ Margen Neto & 2019 & $33 \%$ & Aumentar ingresos \\
\hline & rentable al 2022 & negocio & & 2020 & $37 \%$ & Reducción de costos \\
\hline & & & & 2021 & $52 \%$ & \multirow{6}{*}{$\begin{array}{l}\text { Analizar la demanda del consumidor extranjero } \\
\text { Participación en ferias internacionales }\end{array}$} \\
\hline & & & & 2022 & $65 \%$ & \\
\hline & Lograr que un $15 \%$ de & Incrementar la exportación en el & Montos de ventas al exterior / & 2019 & $6 \%$ & \\
\hline & las ventas totales anuales & orden de $3 \%$ anual & Ventas totales & 2020 & $9 \%$ & \\
\hline & al 2022 sean al exterior & & & 2021 & $12 \%$ & \\
\hline & & & & 2022 & $15 \%$ & \\
\hline \multirow{8}{*}{ } & Aumentar en $15 \%$ los & Aperturar nuevos canales de & \multirow{8}{*}{$\begin{array}{l}\text { Cantidad de canales de } \\
\text { atención del año actual / } \\
\text { Cantidad de canales de } \\
\text { atención del año anterior } \\
\text { \% Satisfacción de clientes }\end{array}$} & 2019 & $8 \%$ & \multirow{8}{*}{$\begin{array}{c}\text { Participación en ferias que tengas más afluencia de } \\
\text { público y que el costo de ingreso sea factible re } \\
\text { recuperar. } \\
\text { Visitar empresas y ofrecer los productos } \\
\text { Establecer procesos de atención al cliente } \\
\text { Realizar encuestas luego de cada transacción. } \\
\text { Definir promociones para incentivar al cliente a utilizar } \\
\text { medios electrónicos en sus pagos } \\
\text { Diseñar empaque para recordación de la marca. }\end{array}$} \\
\hline & canales de atención al & atención en 15\% al 2022 & & 2020 & $10 \%$ & \\
\hline & 2022 & & & 2021 & $12 \%$ & \\
\hline & & & & 2022 & $15 \%$ & \\
\hline & Mejorar la experiencia de & Mejorar la calidad del servicio & & 2019 & $75 \%$ & \\
\hline & compra en un $85 \%$ al & postventa en un $10 \%$ al 2022 & & 2020 & $78 \%$ & \\
\hline & 2022 & & & 2021 & $80 \%$ & \\
\hline & & & & 2022 & $85 \%$ & \\
\hline \multirow{10}{*}{ } & Reducir un $15 \%$ los & Reducir los costos de un & Inversión de las compras del & 2019 & $>40 \%$ & \multirow{4}{*}{$\begin{array}{c}\text { Desarrollar redes de negociación con proveedores } \\
\text { logísticos para mejorar costos } \\
\text { Establecer compras al por mayor para obtener mejores } \\
\text { precios }\end{array}$} \\
\hline & costos en compras a & producto un $5 \%$ & año anterior/ Inversión de las & 2020 & $>40 \%$ & \\
\hline & proveedores al 2022 & & compras del año actual & 2021 & $>40 \%$ & \\
\hline & & & & 2022 & $>40 \%$ & \\
\hline & Lograr que un $20 \%$ de & Implementar plataforma de e- & $\%$ Avance & 2019 & $100 \%$ & Implementar plataforma e-commerce \\
\hline & las ventas totales anuales & commerce al 2019 & & & & Rediseñar la página web \\
\hline & al 2022 sean por medios & Lograr un $10 \%$ de ventas por e- & Cantidad de clientes compran & 2019 & $5 \%$ & \multirow{4}{*}{$\begin{array}{l}\text { Establecer promociones de productos solo vía online } \\
\text { Implementar los mecanismos de pago dentro de la página } \\
\text { web. }\end{array}$} \\
\hline & & commerce al 2020 & por e-commerce del año & 2020 & $10 \%$ & \\
\hline & & Al $202115 \%$ & actual / Cantidad de clientes & 2021 & $15 \%$ & \\
\hline & & Al $202220 \%$ & $\begin{array}{l}\text { compran por e-commerce del } \\
\text { año anterior }\end{array}$ & 2022 & $20 \%$ & \\
\hline \multirow{3}{*}{ 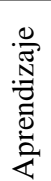 } & Lograr que el $100 \%$ del & Capacitar al $100 \%$ a todas las & $\%$ personas capacitadas & 2019 & $25 \%$ & \multirow{3}{*}{$\begin{array}{l}\text { Capacitar a todo el personal de la empresa acerca del } \\
\text { comercio electrónico y a la fuerza de ventas }\end{array}$} \\
\hline & personal haya recibido & áreas al 2022 & & 2020 & $50 \%$ & \\
\hline & una capacitación al 2022 & & & $\begin{array}{l}2021 \\
2022\end{array}$ & $\begin{array}{c}75 \% \\
100 \%\end{array}$ & \\
\hline
\end{tabular}

Nota. Adaptado de The Balance Scorecard (p. 216), por R. Kaplan y D. Norton, 2000, España: Harvard Business School. Copyrigth 2000 por Gestión 2000. 


\subsection{Responsable de cada una de las Iniciativas}

Se procede a establecer las fases de cada iniciativa y los responsables de su ejecución. Esto fue revisado por el personal interno de la organización en sintonía con la tabla BSC. Las asignaciones de los responsables fueron sugeridos por los miembros de la empresa en una de las reuniones semanales, las cuales no necesariamente fueron dadas según el rol de funciones de los mismos, pero sí de acuerdo a lo que cada uno podía realizar según su experiencia profesional o facilidad de ejecutar dicha acción (ver Tabla 50, 51).

\subsection{Presupuesto de cada una de las Iniciativas}

Se procede a establecer las fases de cada iniciativa, responsables y presupuesto para su ejecución. Estos montos fueron establecidos de acuerdo a lo que las empresas que ofrecen los servicios cobran (ver Tabla 52, 53). En las tablas 54, 55, 56 y 57 se encuentra el detalle de los costos por actividad costos según cada iniciativa por año. Se establecieron estrategias no muy elevadas pero si de gran impacto para poder pagarlas con la ejecución inmediata de las mismas.

\subsection{Cronograma de cada una de las Iniciativas}

En el cronograma se presenta las iniciativas que se llevaran a cabo de cada año del proyecto, del 2019 al 2022. Para hacer más efectiva la búsqueda se indica la ubicación de las tablas según la perspectiva. Para una mejor visualización solo se colocó los meses de actividad.

- P. Financiera: Iniciativas y fecha a elaborarse en los años 2019 (ver Tabla 58); Año 2020 (ver Tabla 59); Año 2021 (ver Tabla 60) y Año 2022 (ver Tabla 61).

- P. Cliente: Iniciativas y fecha a elaborarse en los años 2019 (ver Tabla 62); Año 2020 (ver Tabla 63); Año 2021 (ver Tabla 64) y Año 2022 (ver Tabla 65).

- P. Proceso Interno: Iniciativas y fecha a elaborarse en los años 2019 (ver Tabla 66); Año 2020 (ver Tabla 67); Año 2021 (ver Tabla 68) y Año 2022 (ver Tabla 69).

- P. Aprendizaje: Iniciativas y fecha a elaborarse en los años 2019 (ver Tabla 70); Año 2020 (ver Tabla 71) y Año 2021 (ver Tabla 72) 
Tabla 50

Responsables de Cada Iniciativa de Perspectiva Financiera y Clientes para Incas Jewelry SAC

\begin{tabular}{|c|c|c|c|c|c|c|c|}
\hline & Objetivos estratégicos & Objetivos específicos & Indicadores & Año & Meta & Iniciativa & Responsable \\
\hline \multirow{8}{*}{. } & Hacer la empresa & Aumentar la utilidad neta del & $\%$ Margen Neto & 2019 & $33 \%$ & Aumentar ingresos & Gerente de Tienda \\
\hline & rentable al 2022 & negocio & & 2020 & $37 \%$ & Reducción de costos & Gerente de Operaciones \\
\hline & & & & 2021 & $52 \%$ & & \\
\hline & & & & 2022 & $65 \%$ & & \\
\hline & Lograr que un $15 \%$ de & Incrementar la exportación en el & Montos de ventas al exterior / & 2019 & $6 \%$ & Analizar la demanda del & Gerente de Operaciones \\
\hline & las ventas totales anuales & orden de $3 \%$ anual & Ventas totales & 2020 & $9 \%$ & consumidor extranjero & \\
\hline & al 2022 sean al exterior & & & 2021 & $12 \%$ & Participación en ferias & Gerente de Operaciones \\
\hline & & & & 2022 & $15 \%$ & internacionales & \\
\hline \multirow{12}{*}{ 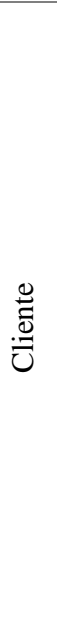 } & Aumentar en $15 \%$ los & Aperturar nuevos canales de & Cantidad de canales de & 2019 & $8 \%$ & Participación en ferias que & Gerente de Operaciones \\
\hline & canales de atención al & atención en $15 \%$ al 2022 & atención del año actual / & 2020 & $10 \%$ & tengas más afluencia de & \\
\hline & 2022 & & Cantidad de canales de & 2021 & $12 \%$ & público y que el costo de & \\
\hline & & & atención del año anterior & 2022 & $15 \%$ & $\begin{array}{l}\text { ingreso sea factible re } \\
\text { recuperar. }\end{array}$ & \\
\hline & & & & & & $\begin{array}{l}\text { Visitar empresas y ofrecer } \\
\text { los productos }\end{array}$ & Gerente de Operaciones \\
\hline & \multirow{7}{*}{$\begin{array}{l}\text { Mejorar la experiencia de } \\
\text { compra en un } 85 \% \text { al } \\
2022\end{array}$} & Mejorar la calidad del servicio & \% Satisfacción de clientes & 2019 & $75 \%$ & Establecer procesos de & Gerente de Operaciones \\
\hline & & postventa en un $10 \%$ al 2022 & & 2020 & $78 \%$ & atención al cliente & \\
\hline & & & & 2021 & $80 \%$ & Realizar encuestas luego de & Gerente de Tienda \\
\hline & & & & 2022 & $85 \%$ & $\begin{array}{l}\text { cada transacción. } \\
\text { Definir nromociones }\end{array}$ & \\
\hline & & & & & & $\begin{array}{l}\text { Definir promociones para } \\
\text { incentivar al cliente a }\end{array}$ & $\begin{array}{c}\text { Gerente de Operaciones y } \\
\text { de Producción }\end{array}$ \\
\hline & & & & & & $\begin{array}{l}\text { utilizar medios electrónicos } \\
\text { en sus pagos }\end{array}$ & \\
\hline & & & & & & $\begin{array}{l}\text { Diseñar empaque para } \\
\text { recordación de la marca. }\end{array}$ & Gerente de Producción \\
\hline
\end{tabular}

Nota. Adaptado de The Balance Scorecard (p. 216), por R. Kaplan y D. Norton, 2000, España: Harvard Business School. Copyrigth 2000 por Gestión 2000. 
Tabla 51

Responsables de Cada Iniciativa de Perspectiva Interna y Aprendizaje

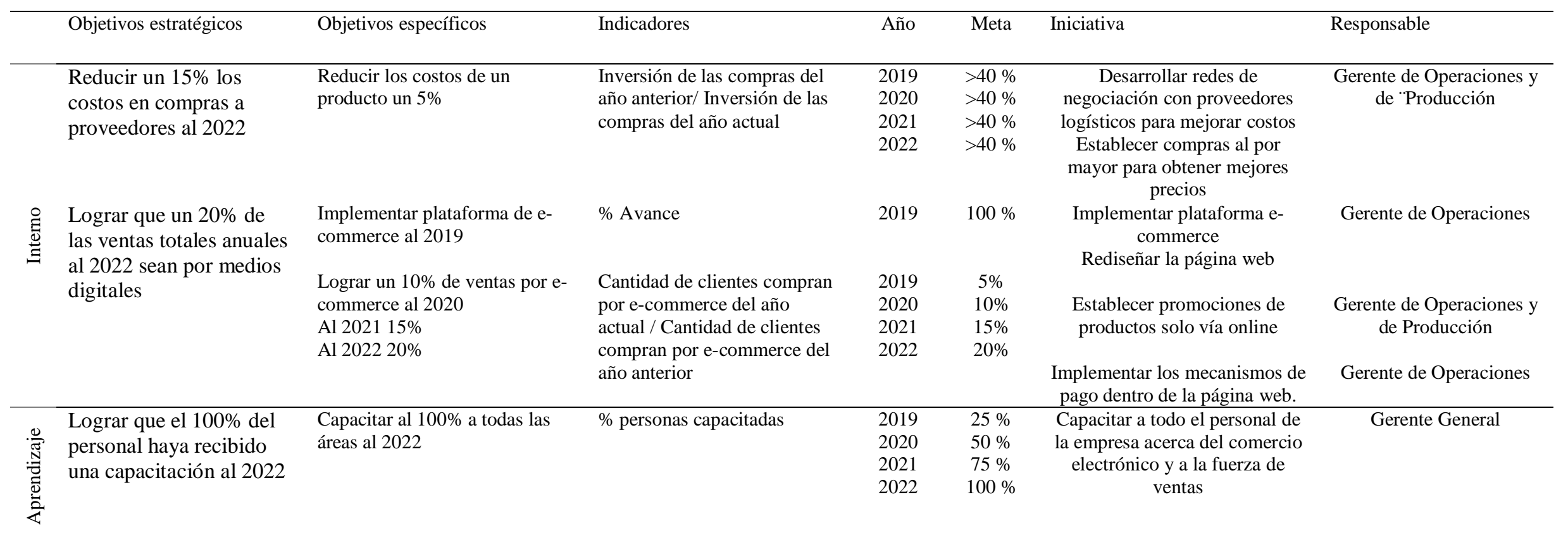

Nota. Adaptado de The Balance Scorecard (p. 216), por R. Kaplan y D. Norton, 2000, España: Harvard Business School. Copyrigth 2000 por Gestión 2000. 
Tabla 52

Presupuesto de Cada Iniciativa de la Perspectiva Financiera y Cliente

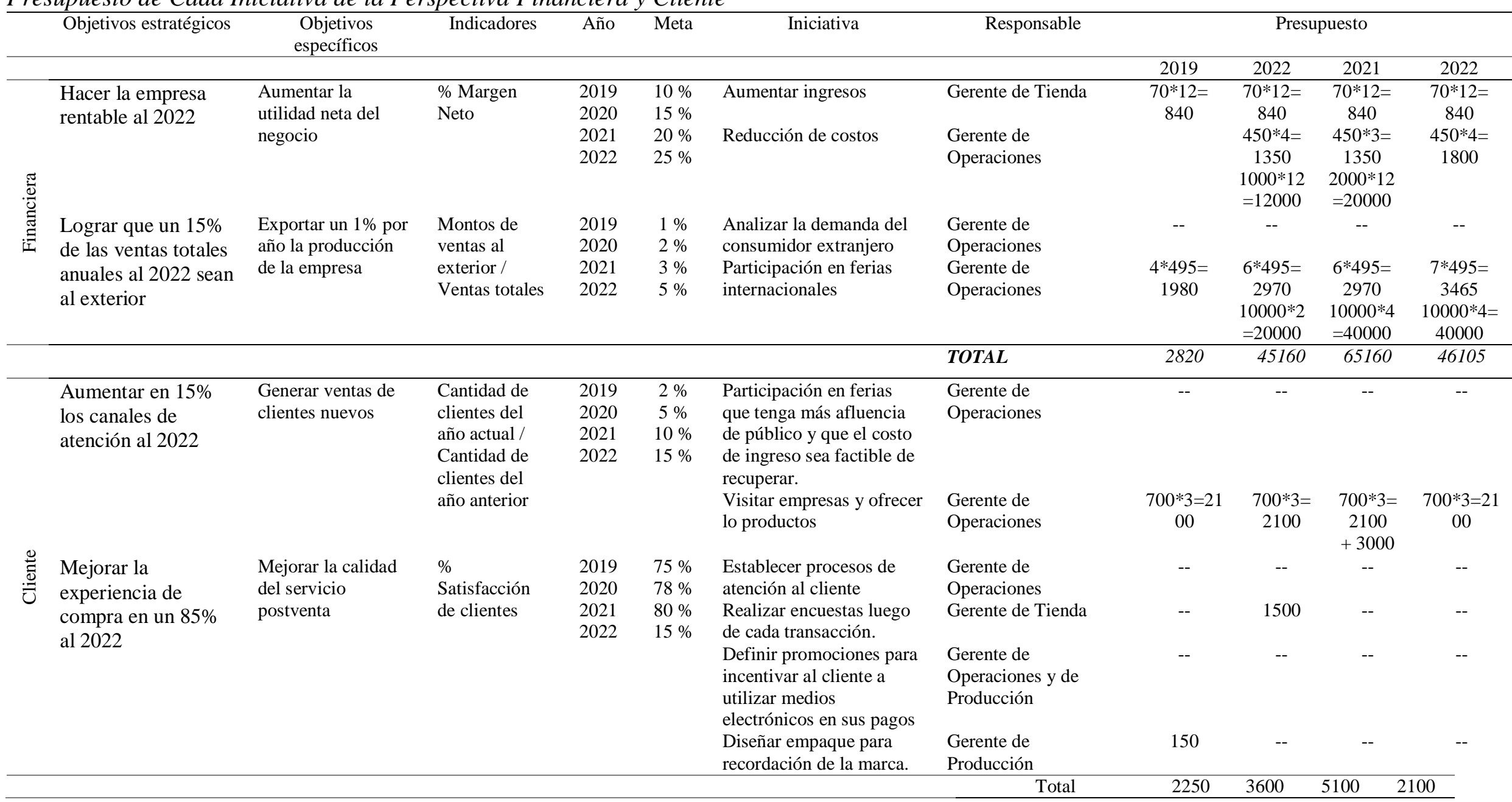

Nota. Adaptado de The Balance Scorecard (p. 216), por R. Kaplan y D. Norton, 2000, España: Harvard Business School. Copyrigth 2000 por Gestión 2000. 
Tabla 53

Presupuesto de Cada Iniciativa de la Perspectiva Interna y Aprendizaje

\begin{tabular}{|c|c|c|c|c|c|c|c|c|c|c|c|}
\hline & \multirow{2}{*}{$\begin{array}{l}\text { Objetivos } \\
\text { estratégicos }\end{array}$} & \multirow{2}{*}{$\begin{array}{l}\text { Objetivos } \\
\text { específicos }\end{array}$} & \multirow[t]{2}{*}{ Indicadores } & \multirow[t]{2}{*}{ Año } & \multirow[t]{2}{*}{ Meta } & \multirow[t]{2}{*}{ Iniciativa } & \multirow[t]{2}{*}{ Responsable } & \multicolumn{4}{|c|}{ Presupuesto } \\
\hline & & & & & & & & 2019 & 2022 & 2021 & 2022 \\
\hline \multirow{15}{*}{ 异 } & Reducir un $15 \%$ & Reducir los costos & Inversión de las & 2019 & $>40$ & Desarrollar redes de & Gerente de & -- & -- & -- & -- \\
\hline & los costos en & de un producto un & compras del año & 2020 & $\%$ & negociación con & Operaciones y de & & & & \\
\hline & compras a & $40 \%$ & anterior/ Inversión & 2021 & $>40$ & proveedores logísticos & "Producción & & & & \\
\hline & proveedores al & & de las compras del & & $\%$ & para mejorar costos & & & & & \\
\hline & 2022 & & año actual & & $\begin{array}{l}>40 \\
\% \\
>40 \\
\%\end{array}$ & $\begin{array}{l}\text { Establecer compras al } \\
\text { por mayor para obtener } \\
\text { mejores precios }\end{array}$ & & -- & -- & -- & -- \\
\hline & Lograr que un & Implementar & $\%$ Avance & 2019 & $0 \%$ & Implementar & Gerente de & 4680 & -- & -- & 1000 \\
\hline & $20 \%$ de las & plataforma de e- & & 2020 & 100 & plataforma e-commerce & Operaciones & & & & \\
\hline & ventas totales & commerce al 2019 & & 2021 & $\%$ & Rediseñar la web & & & & & \\
\hline & anuales al 2022 & & & 2022 & $0 \%$ & Establecer & & -- & -- & -- & -- \\
\hline & sean por medios & & & & $0 \%$ & promociones de & Gerente de & & & & \\
\hline & & Lograr un $10 \%$ de & $\begin{array}{l}\text { Cantidad de } \\
\text { clientes compran }\end{array}$ & $\begin{array}{l}2019 \\
2020\end{array}$ & & $\begin{array}{l}\text { productos solo vía } \\
\text { online }\end{array}$ & $\begin{array}{l}\text { Operaciones y de } \\
\text { Producción }\end{array}$ & - & -- & -- & -- \\
\hline & & commerce al 2020 & por e-commerce & 2021 & $0 \%$ & Implementar los & Gerente de & & & & \\
\hline & & Al $202115 \%$ & del año actual / & 2022 & $0 \%$ & mecanismos de pago & Operaciones & & & & \\
\hline & & Al $202220 \%$ & $\begin{array}{l}\text { Cantidad de } \\
\text { clientes compran } \\
\text { por e-commerce } \\
\text { del año anterior }\end{array}$ & & $\begin{array}{l}15 \% \\
20 \%\end{array}$ & $\begin{array}{l}\text { dentro de la página } \\
\text { web. }\end{array}$ & & & & & \\
\hline & & & & & & & Total & 2820 & 45160 & 65160 & 46105 \\
\hline \multirow{6}{*}{ 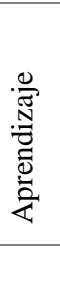 } & Lograr que el & Promover & $\%$ personas & 2019 & $0 \%$ & Capacitar a todo el & Gerente General & 9000 & -- & -- & -- \\
\hline & $100 \%$ del & capacitación a las & capacitadas & 2020 & $60 \%$ & personal de la empresa & & & & & \\
\hline & personal haya & unidades de & & 2021 & 100 & acerca del comercio & & & & & \\
\hline & recibido una & negocio & & 2022 & $\%$ & electrónico y a la & & & & & \\
\hline & $\begin{array}{l}\text { capacitación al } \\
2022\end{array}$ & & & & $0 \%$ & fuerza de ventas & & & & & \\
\hline & & & & & & & Total & 9000 & & & \\
\hline
\end{tabular}




\section{Tabla 54}

Detalle de Costos de Iniciativas Financieras

\begin{tabular}{|c|c|c|c|c|c|}
\hline Iniciativas Financieras & Descripción de las Iniciativas & 2019 & 2020 & 2021 & 2022 \\
\hline \multirow[t]{18}{*}{ Aumentar ingresos } & Generar campañas en fanpage & $70 * 12=840$ & $70 * 12=840$ & $70 * 12=840$ & $70 * 12=840$ \\
\hline & Publicidad en redes sociales & & & & \\
\hline & Ampliar canales de ventas & & & & \\
\hline & Buscar nuevas tendencias de la competencia & & & & \\
\hline & Producir nuevos diseños según tendencias elegidas (cuños) & & $450 * 4=1800$ & $450 * 3=1350$ & $450 * 4=1800$ \\
\hline & Ampliar el portafolio de productos & & & & \\
\hline & Atención permanente en lo que hace la competencia & & & & \\
\hline & Ampliar la fuerza de ventas & & $1000 * 12=12000$ & $2000 * 12=20000$ & \\
\hline & Invertir recursos y esfuerzo en los canales que tengas más ingresos & & & & \\
\hline & Ingresos obtenidos por los nuevos canales de venta & & & & \\
\hline & Evaluación de los costos del local & & & & \\
\hline & Ampliar publicidad en medios escritos & & & & \\
\hline & Definir un producto bandera del negocio & & & & \\
\hline & Buscar socios estratégicos & & & & \\
\hline & Invertir en publicidad en los medios que tengan mayor alcance al público & & & & \\
\hline & objetivo. & & & & \\
\hline & Añadir al portafolio de productos & & & & \\
\hline & Mejorar atributos del portafolio & & & & \\
\hline \multirow[t]{8}{*}{ Reducción de costos } & Listar los productos de baja demanda & & & & \\
\hline & Realizar compras planificadas de insumos & & & & \\
\hline & Buscar productos sustitutos & & & & \\
\hline & Mantener control de compras a proveedores & & & & \\
\hline & Establecer esquema de comisiones rentable para la empresa. & & & & \\
\hline & Mantener un control intensivo de costos & & & & \\
\hline & Evaluación permanente de los costos de productos de portafolio & & & & \\
\hline & Retirar los productos de baja demanda & & & & \\
\hline \multirow{8}{*}{$\begin{array}{l}\text { Analizar la demanda } \\
\text { consumidor extranjero }\end{array}$} & Evaluar las compras del año anterior de los clientes extranjeros & & & & \\
\hline & Seleccionar los modelos de la tienda de mayor salida a turistas & & & & \\
\hline & Buscar las ferias más rentables y agendar las nuevas ferias del año & & & & \\
\hline & Promover el portafolio de productos alineado a la exportación & & & & \\
\hline & Analizar las ferias de mayor rentabilidad & & & & \\
\hline & Concertar venta con compradores a largo plazo & & & & \\
\hline & $\begin{array}{l}\text { Búsqueda constante de nuevas tendencias en el mercado exterior } \\
\text { ferias del año }\end{array}$ & & & & \\
\hline & Búsqueda constante de nuevas tendencias en el mercado exterior & & & & \\
\hline \multirow{3}{*}{$\begin{array}{l}\text { Participación } \\
\text { internacionales }\end{array}$} & Envío de muestras & $4 * 495=1980$ & $6 * 495=2970$ & $6 * 495=2970$ & $7 * 495=3465$ \\
\hline & Presentarse a las ferias más rentables & & $10000 * 2=20000$ & $10000 * 4=40000$ & $10000 * 4=40000$ \\
\hline & Buscar socio estratégico para cubrir costos de ferias internacionales & & & & \\
\hline
\end{tabular}


Tabla 55

Detalle de Costos de Iniciativas Cliente

\begin{tabular}{|c|c|c|c|c|c|}
\hline Iniciativas Clientes & Descripción de las Iniciativas & 2019 & 2020 & 2021 & 2022 \\
\hline $\begin{array}{l}\text { Participación en ferias que } \\
\text { tenga más afluencia de público } \\
\text { y que el costo de ingreso sea } \\
\text { factible de recuperar. }\end{array}$ & $\begin{array}{l}\text { Listar a los diseñadores que pueden formar parte del equipo } \\
\text { Entrevistarse con los diseñadores para establecer alianzas } \\
\text { Firmar alianzas o acuerdos y tener productos en concesión } \\
\text { Buscar acuerdos con nuevos diseñadores } \\
\text { Seleccionar las ferias de mayor concurrencia } \\
\text { Diseñar modelos solo para exportación } \\
\text { Certificar las piezas producidas }\end{array}$ & & & & \\
\hline $\begin{array}{l}\text { Visitar empresas y ofrecer lo } \\
\text { productos }\end{array}$ & $\begin{array}{l}\text { Servicio de fotografía para publicar imágenes de calidad } \\
\text { Listar empresas confiables } \\
\text { Ofrecer productos según el público de dicha empresa } \\
\text { Establecer bonos por ventas mensuales según productos. } \\
\text { Mantener alianzas solo con las tiendas rentables } \\
\text { Dar créditos a empleados de empresas sujetas a descuentos por planilla } \\
\text { mediante acuerdo con el área de RRHH de la empresa. } \\
\text { Registrar a Incas Jewelry como proveedor formal de las empresas a las } \\
\text { cuales se les vende. }\end{array}$ & $700 * 3=2100$ & $700 * 3=2100$ & $700 * 3=2100$ & $700 * 2=1400$ \\
\hline $\begin{array}{l}\text { Establecer procesos de atención } \\
\text { al cliente }\end{array}$ & $\begin{array}{l}\text { Controlar la fortaleza y calidad de los productos } \\
\text { Definir tiempos de atención y respuesta a los incidentes post venta. } \\
\text { A través de los medios digitales mantener contacto con los clientes. }\end{array}$ & & & & \\
\hline $\begin{array}{l}\text { Realizar encuestas luego de } \\
\text { cada transacción. }\end{array}$ & $\begin{array}{l}\text { Establecer encuesta vía web y en tienda para buscar tendencias y } \\
\text { satisfacción al cliente } \\
\text { Evaluar las acciones que se toman a partir de la información de las } \\
\text { encuestas. } \\
\text { Implementar BD de clientes para retroalimentación } \\
\text { Participar como empresa en encuestas reconocidas que miden a las } \\
\text { empresas más queridas y reconocidas. } \\
\text { Establecer contratos con motorizados que puedan recoger y entregar } \\
\text { productos vendidos o reparados. }\end{array}$ & & 1500 & & \\
\hline $\begin{array}{l}\text { Definir promociones para } \\
\text { incentivar al cliente a utilizar } \\
\text { medios electrónicos en sus } \\
\text { pagos }\end{array}$ & $\begin{array}{l}\text { Implementar acciones viables } \\
\text { Implementar acciones de marketing verde. } \\
\text { Mantener publicidad. } \\
\text { Establecer mecanismos para que los clientes tradicionales que solo } \\
\text { compran en tienda inicien su experiencia de compra a través de medios } \\
\text { digitales. }\end{array}$ & & & & \\
\hline $\begin{array}{l}\text { Diseñar empaque para } \\
\text { recordación de la marca. }\end{array}$ & $\begin{array}{l}\text { Diseñar un empaque biodegradable } \\
\text { Publicitar esta política de Responsabilidad empresarial } \\
\text { Implementar pasarela de pago en la web } \\
\text { Definir promociones solo con pago por web }\end{array}$ & 150 & & & \\
\hline
\end{tabular}


Tabla 56

Detalle de Costos de Iniciativas Internas

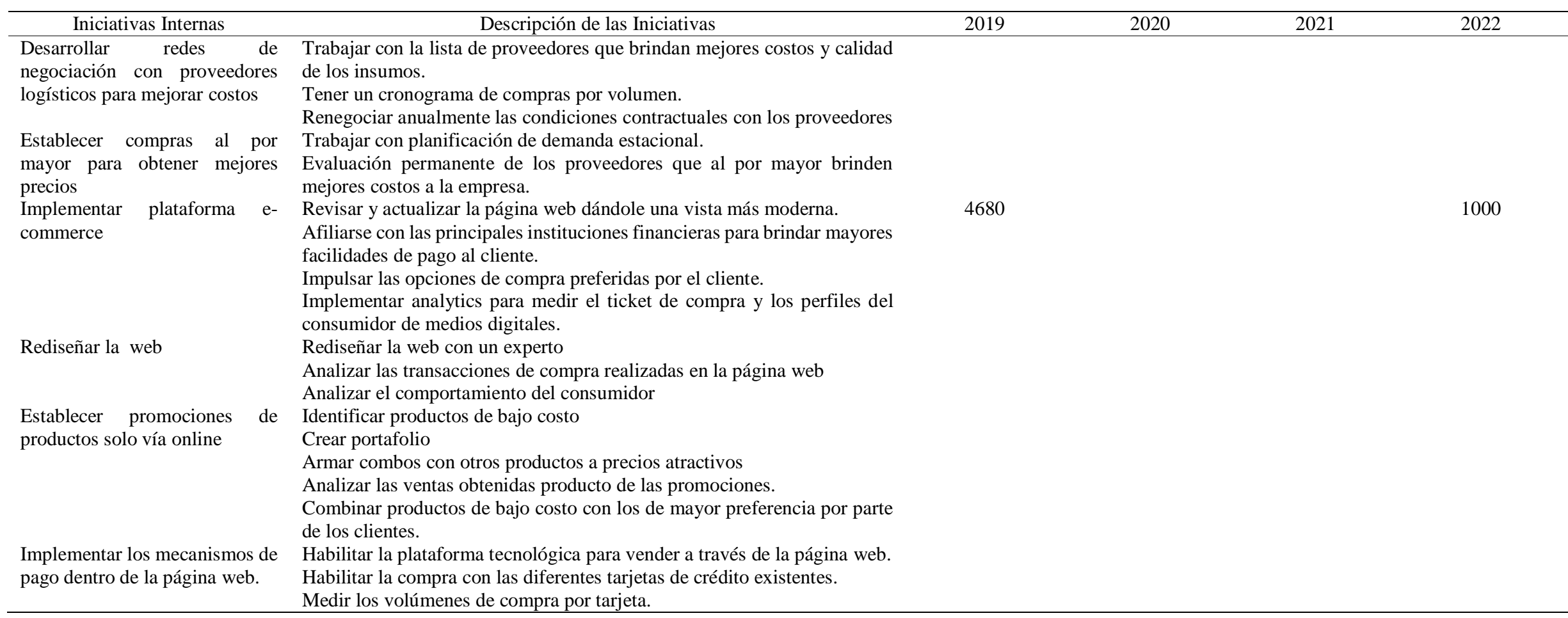

\section{Tabla 57}

\section{Detalle de Costos de Iniciativas Aprendizaje}

\begin{tabular}{llll}
\hline \multicolumn{1}{c}{ Iniciativas Aprendizaje } & \multicolumn{1}{c}{ Descripción de las Iniciativas } & 2019 & 2020 \\
\hline $\begin{array}{l}\text { Capacitar a todo el personal de } \\
\text { la empresa acerca del comercio } \\
\text { electrónico y a la fuerza de }\end{array}$ & Identificar las fortalezas y las oportunidades de mejora por rol. & Establecer un plan de capacitación para cada empleado para fortalecer a la \\
empresa. & $\begin{array}{l}\text { Todo el personal de la empresa independientemente del rol debe tener } \\
\text { ventas }\end{array}$ & $4500 * 2=9000$ \\
& conocimiento sobre el negocio y los principales productos.
\end{tabular}


Tabla 58

Cronograma 2019 de Cada Iniciativa y sus Responsables de la Perspectiva Financiera Propuestas para Incas Jewelry SAC

\begin{tabular}{|c|c|c|c|c|c|c|c|c|c|c|}
\hline \multicolumn{2}{|l|}{ Iniciativa } & Responsable & Ene -19 & Feb - 19 & Mar -19 & May -19 & Ago -19 & Oct -19 & Nov -19 & Dic -19 \\
\hline \multicolumn{2}{|c|}{ Aumentar ingresos } & $\begin{array}{l}\text { Gerente de } \\
\text { Tienda }\end{array}$ & $\begin{array}{l}\text { Generar } \\
\text { campañas en } \\
\text { fanpage anual }\end{array}$ & $\begin{array}{l}\text { Publicidad en } \\
\text { redes sociales }\end{array}$ & $\begin{array}{l}\text { Ampliar } \\
\text { canales de } \\
\text { ventas }\end{array}$ & $\begin{array}{l}\text { Producir } \\
\text { nuevos } \\
\text { diseños según }\end{array}$ & & $\begin{array}{l}\text { Buscar } \\
\text { nuevas } \\
\text { tendencias }\end{array}$ & & \\
\hline $\begin{array}{l}\text { Reducción de } \\
\text { costos }\end{array}$ & & $\begin{array}{l}\text { Gerente de } \\
\text { Operaciones }\end{array}$ & $\begin{array}{l}\text { Listar los } \\
\text { productos de } \\
\text { baja demanda }\end{array}$ & $\begin{array}{l}\text { Realizar compras } \\
\text { planificadas de } \\
\text { insumos } \\
\text { Buscar productos } \\
\text { sustitutos }\end{array}$ & $\begin{array}{l}\text { Cerrar la } \\
\text { tienda y } \\
\text { venta de } \\
\text { enceres }\end{array}$ & $\begin{array}{l}\text { tendencias } \\
\text { elegidas ( } 3 \\
\text { cuños) }\end{array}$ & & $\begin{array}{l}\text { de la } \\
\text { competencia }\end{array}$ & & $\begin{array}{l}\text { Evaluar } \\
\text { desempeño } \\
\text { de la } \\
\text { acción }\end{array}$ \\
\hline $\begin{array}{l}\text { Analizar } \\
\text { demanda } \\
\text { consumidor } \\
\text { extranjero }\end{array}$ & $\begin{array}{r}\text { la } \\
\text { del }\end{array}$ & $\begin{array}{l}\text { Gerente de } \\
\text { Operaciones }\end{array}$ & $\begin{array}{l}\text { Evaluar las } \\
\text { compras del } \\
\text { año anterior } \\
\text { de los } \\
\text { clientes }\end{array}$ & $\begin{array}{l}\text { Seleccionar los } \\
\text { modelos de la } \\
\text { tienda de mayor } \\
\text { salida a turistas }\end{array}$ & $\begin{array}{l}\text { Buscar las } \\
\text { ferias más } \\
\text { rentables }\end{array}$ & & & & & \\
\hline $\begin{array}{l}\text { Participación } \\
\text { ferias } \\
\text { internacionales }\end{array}$ & en & $\begin{array}{l}\text { Gerente de } \\
\text { Operaciones }\end{array}$ & extranjeros & & $\begin{array}{l}\text { Envío de } \\
\text { muestras }\end{array}$ & $\begin{array}{l}\text { Envío de } \\
\text { muestras } \\
\text { Presentarse a } \\
1 \text { ferias } \\
\text { internacional }\end{array}$ & $\begin{array}{l}\text { Envío de } \\
\text { muestras }\end{array}$ & $\begin{array}{l}\text { Envío de } \\
\text { muestras }\end{array}$ & $\begin{array}{l}\text { Analizar las } \\
\text { ferias de } \\
\text { mayor } \\
\text { rentabilidad }\end{array}$ & \\
\hline
\end{tabular}


Tabla 59

Cronograma 2020 de Cada Iniciativa y sus Responsables de la Perspectiva Financiera propuestas para Incas Jewelry SAC

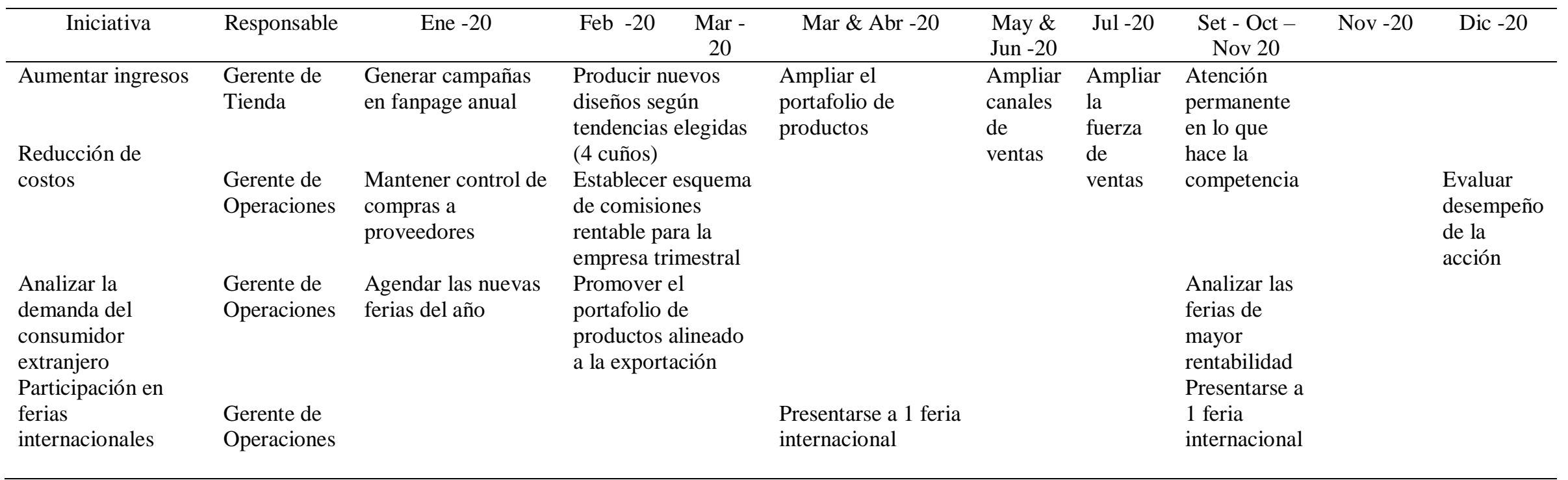


Tabla 60

Cronograma 2021 de Cada Iniciativa y sus Responsables de la Perspectiva Financiera propuestas para Incas Jewelry SAC

\begin{tabular}{|c|c|c|c|c|c|c|c|}
\hline Iniciativa & Responsable & Ene -21 & Feb -21 & Mar -21 & May -21 & Nov -21 & Dic -21 \\
\hline Aumentar ingresos & $\begin{array}{l}\text { Gerente de } \\
\text { Tienda }\end{array}$ & $\begin{array}{l}\text { Analizar los ingresos } \\
\text { obtenidos por los } \\
\text { nuevos canales de } \\
\text { venta } \\
\text { Generar campañas en }\end{array}$ & $\begin{array}{l}\text { Invertir recursos y } \\
\text { esfuerzo en los } \\
\text { canales que tengas } \\
\text { más ingresos }\end{array}$ & $\begin{array}{l}\text { Ampliar publicidad en } \\
\text { medios escritos }\end{array}$ & $\begin{array}{l}\text { Producir nuevos } \\
\text { diseños según } \\
\text { tendencias elegidas } \\
\text { ( } 4 \text { cuños) }\end{array}$ & & \\
\hline Reducción de costos & $\begin{array}{l}\text { Gerente de } \\
\text { Operaciones }\end{array}$ & fanpage anual & $\begin{array}{l}\text { Mantener esquema } \\
\text { de comisiones } \\
\text { rentable para la } \\
\text { empresa trimestral }\end{array}$ & & & & $\begin{array}{l}\text { Evaluar } \\
\text { desempeño } \\
\text { de las } \\
\text { acciones }\end{array}$ \\
\hline $\begin{array}{l}\text { Analizar la demanda } \\
\text { del consumidor } \\
\text { extranjero }\end{array}$ & $\begin{array}{l}\text { Gerente de } \\
\text { Operaciones }\end{array}$ & & $\begin{array}{l}\text { Concertar venta } \\
\text { con compradores a } \\
\text { largo plazo }\end{array}$ & & & & \\
\hline $\begin{array}{l}\text { Participación en } \\
\text { ferias } \\
\text { internacionales }\end{array}$ & $\begin{array}{l}\text { Gerente de } \\
\text { Operaciones }\end{array}$ & & & $\begin{array}{l}\text { Asistir } 2 \text { ferias } \\
\text { internacionales } \\
\text { Buscar socio estratégico para } \\
\text { cubrir costos de ferias } \\
\text { internacionales }\end{array}$ & & $\begin{array}{l}\text { Asistir } 2 \text { ferias } \\
\text { internacionales }\end{array}$ & \\
\hline
\end{tabular}


Tabla 61

Cronograma 2022 de cada Iniciativa y sus Responsables de la Perspectiva Financiera propuestas para Incas Jewelry SAC

\begin{tabular}{|c|c|c|c|c|c|c|c|c|}
\hline \multicolumn{2}{|l|}{ Iniciativa } & Responsable & Ene -22 & Feb -22 & Mar -22 & Abr -22 & Jun -22 & Dic -22 \\
\hline \multicolumn{2}{|c|}{ Aumentar ingresos } & $\begin{array}{l}\text { Gerente de } \\
\text { Tienda }\end{array}$ & $\begin{array}{l}\text { Definir un producto } \\
\text { bandera del negocio } \\
\text { Generar campañas en } \\
\text { fanpage anual }\end{array}$ & $\begin{array}{l}\text { Buscar socios } \\
\text { estratégicos }\end{array}$ & $\begin{array}{l}\text { Invertir en publicidad } \\
\text { en los medios que } \\
\text { tengan mayor alcance } \\
\text { al público objetivo. }\end{array}$ & $\begin{array}{l}\text { Añadir al portafolio } \\
\text { de productos }\end{array}$ & $\begin{array}{l}\text { Mejorar } \\
\text { atributos del } \\
\text { portafolio }\end{array}$ & \\
\hline \multicolumn{2}{|l|}{$\begin{array}{l}\text { Reducción de } \\
\text { costos }\end{array}$} & $\begin{array}{l}\text { Gerente de } \\
\text { Operaciones }\end{array}$ & $\begin{array}{l}\text { Mantener un control } \\
\text { intensivo de costos } \\
\text { Mantener esquema de } \\
\text { comisiones rentable } \\
\text { para la empresa } \\
\text { trimestral }\end{array}$ & $\begin{array}{l}\text { Evaluación } \\
\text { permanente de los } \\
\text { costos de productos } \\
\text { de portafolio }\end{array}$ & & $\begin{array}{l}\text { Retirar los } \\
\text { productos de baja } \\
\text { demanda }\end{array}$ & & $\begin{array}{l}\text { Evaluar } \\
\text { desempeño } \\
\text { de las } \\
\text { acciones }\end{array}$ \\
\hline $\begin{array}{l}\text { Analizar } \\
\text { demanda } \\
\text { consumidor } \\
\text { extranjero }\end{array}$ & $\begin{array}{r}\text { la } \\
\text { del }\end{array}$ & $\begin{array}{l}\text { Gerente de } \\
\text { Operaciones }\end{array}$ & $\begin{array}{l}\text { Búsqueda constante de } \\
\text { nuevas tendencias en el } \\
\text { mercado exterior } \\
\text { ferias del año }\end{array}$ & $\begin{array}{l}\text { Búsqueda constante } \\
\text { de nuevas tendencias } \\
\text { en el mercado exterior }\end{array}$ & & & & $\begin{array}{l}\text { Evaluar } \\
\text { desempeño } \\
\text { de las } \\
\text { acciones }\end{array}$ \\
\hline $\begin{array}{l}\text { Participación } \\
\text { ferias } \\
\text { internacionales }\end{array}$ & en & $\begin{array}{l}\text { Gerente de } \\
\text { Operaciones }\end{array}$ & & & $\begin{array}{l}\text { Mantener buena } \\
\text { relación con socios } \\
\text { locales y extranjeros } \\
\text { mediante bonos y } \\
\text { promociones }\end{array}$ & & & \\
\hline
\end{tabular}


Tabla 62

Cronograma 2019 de Cada Iniciativa y sus Responsables de la Perspectiva Cliente Propuestas para Incas Jewelry SAC

\begin{tabular}{|c|c|c|c|c|c|c|c|}
\hline Iniciativa & Responsable & Ene -19 & Feb - 19 & Mar -19 & Abr -19 & May -19 & Dic -19 \\
\hline $\begin{array}{l}\text { Participación en ferias } \\
\text { que tengas más } \\
\text { afluencia de público y } \\
\text { que el costo de ingreso } \\
\text { sea factible re } \\
\text { recuperar. }\end{array}$ & $\begin{array}{l}\text { Gerente de } \\
\text { Operaciones }\end{array}$ & $\begin{array}{l}\text { Listar a los diseñadores } \\
\text { que pueden formar parte } \\
\text { del equipo } \\
\text { Entrevistarse con los } \\
\text { diseñadores para } \\
\text { establecer alianzas }\end{array}$ & $\begin{array}{l}\text { Firmar alianzas o } \\
\text { acuerdos y tener } \\
\text { productos en } \\
\text { concesión }\end{array}$ & $\begin{array}{l}\text { Buscar acuerdos } \\
\text { con nuevos } \\
\text { diseñadores }\end{array}$ & & & $\begin{array}{l}\text { Evaluar desempeño } \\
\text { de las acciones }\end{array}$ \\
\hline $\begin{array}{l}\text { Visitar empresas y } \\
\text { ofrecer lo productos }\end{array}$ & $\begin{array}{l}\text { Gerente de } \\
\text { Operaciones }\end{array}$ & $\begin{array}{l}\text { Servicio de fotografía } \\
\text { para publicar imágenes } \\
\text { de calidad }\end{array}$ & $\begin{array}{l}\text { Listar empresas } \\
\text { confiables } \\
\text { Ofrecer productos } \\
\text { según el público de } \\
\text { dicha empresa }\end{array}$ & $\begin{array}{l}\text { Establecer bonos } \\
\text { por ventas } \\
\text { mensuales según } \\
\text { productos. }\end{array}$ & $\begin{array}{l}\text { Servicio de } \\
\text { fotografía para } \\
\text { publicar } \\
\text { imágenes de } \\
\text { calidad }\end{array}$ & $\begin{array}{l}\text { Servicio de } \\
\text { fotografía } \\
\text { para publicar } \\
\text { imágenes de } \\
\text { calidad }\end{array}$ & $\begin{array}{l}\text { Servicio de fotografía } \\
\text { para publicar } \\
\text { imágenes de calidad }\end{array}$ \\
\hline $\begin{array}{l}\text { Establecer procesos de } \\
\text { atención al cliente }\end{array}$ & $\begin{array}{l}\text { Gerente de } \\
\text { Operaciones }\end{array}$ & $\begin{array}{l}\text { Controlar la fortaleza y } \\
\text { calidad de los productos }\end{array}$ & & & & & $\begin{array}{l}\text { Evaluar desempeño } \\
\text { de las acciones }\end{array}$ \\
\hline $\begin{array}{l}\text { Realizar encuestas } \\
\text { luego de cada } \\
\text { transacción. }\end{array}$ & $\begin{array}{l}\text { Gerente de } \\
\text { Tienda }\end{array}$ & $\begin{array}{l}\text { Establecer encuesta vía } \\
\text { web y en tienda para } \\
\text { buscar tendencias y } \\
\text { satisfacción al cliente }\end{array}$ & & & & & \\
\hline $\begin{array}{l}\text { Definir promociones } \\
\text { para incentivar al } \\
\text { cliente a utiliza medios } \\
\text { electrónicos en sus } \\
\text { pagos }\end{array}$ & $\begin{array}{l}\text { Gerente de } \\
\text { Operaciones } \\
\text { y de } \\
\text { Producción }\end{array}$ & $\begin{array}{l}\text { Implementar acciones } \\
\text { viables }\end{array}$ & $\begin{array}{l}\text { Publicitar esta política } \\
\text { de Responsabilidad } \\
\text { empresarial }\end{array}$ & & & & \\
\hline $\begin{array}{l}\text { Diseñar empaque para } \\
\text { recordación de la } \\
\text { marca. }\end{array}$ & $\begin{array}{l}\text { Gerente de } \\
\text { Producción }\end{array}$ & $\begin{array}{l}\text { Diseñar un empaque } \\
\text { biodegrabable. }\end{array}$ & $\begin{array}{l}\text { Implementar pasarela } \\
\text { de pago en la web }\end{array}$ & $\begin{array}{l}\text { Definir } \\
\text { promociones solo } \\
\text { con pago por web }\end{array}$ & & & \\
\hline
\end{tabular}


Tabla 63

Cronograma 2020 de Cada Iniciativa y sus Responsables de la Perspectiva Cliente propuestas para Incas Jewelry SAC

\begin{tabular}{|c|c|c|c|c|c|}
\hline Iniciativa & Responsable & Ene -20 & Feb - 20 & Mar -20 & Dic -20 \\
\hline $\begin{array}{l}\text { Participación en ferias que } \\
\text { tengas más afluencia de } \\
\text { público y que el costo de } \\
\text { ingreso sea factible re } \\
\text { recuperar. }\end{array}$ & $\begin{array}{l}\text { Gerente de } \\
\text { Operaciones }\end{array}$ & $\begin{array}{l}\text { Seleccionar las ferias de } \\
\text { mayor concurrencia }\end{array}$ & $\begin{array}{l}\text { Diseñar modelos solo } \\
\text { para exportación }\end{array}$ & $\begin{array}{l}\text { Certificar las } \\
\text { piezas producidas }\end{array}$ & $\begin{array}{l}\text { Evaluar desempeño } \\
\text { de las acciones }\end{array}$ \\
\hline $\begin{array}{l}\text { Visitar empresas y ofrecer lo } \\
\text { productos }\end{array}$ & $\begin{array}{l}\text { Gerente de } \\
\text { Operaciones }\end{array}$ & $\begin{array}{l}\text { Mantener alianzas solo con las } \\
\text { tiendas rentables } \\
\text { Servicio de fotografía para } \\
\text { publicar imágenes de calidad }\end{array}$ & $\begin{array}{l}\text { Dar créditos a } \\
\text { empleados de empresas } \\
\text { sujetas a descuentos } \\
\text { por planilla mediante } \\
\text { acuerdo con el área de } \\
\text { RRHH de la empresa. }\end{array}$ & & $\begin{array}{l}\text { Servicio de fotografía } \\
\text { para publicar } \\
\text { imágenes de calidad }\end{array}$ \\
\hline $\begin{array}{l}\text { Establecer procesos de } \\
\text { atención al cliente }\end{array}$ & $\begin{array}{l}\text { Gerente de } \\
\text { Operaciones }\end{array}$ & $\begin{array}{l}\text { Definir tiempos de atención y } \\
\text { respuesta a los incidentes post } \\
\text { venta. }\end{array}$ & & & $\begin{array}{l}\text { Evaluar desempeño } \\
\text { de las acciones }\end{array}$ \\
\hline $\begin{array}{l}\text { Realizar encuestas luego de } \\
\text { cada transacción. }\end{array}$ & $\begin{array}{l}\text { Gerente de } \\
\text { Tienda }\end{array}$ & $\begin{array}{l}\text { Evaluar las acciones que se } \\
\text { toman a partir de la } \\
\text { información de las encuestas. } \\
\text { Implementar BD de clientes } \\
\text { para retroalimentación }\end{array}$ & & & \\
\hline $\begin{array}{l}\text { Definir promociones para } \\
\text { incentivar al cliente a utiliza } \\
\text { medios electrónicos en sus } \\
\text { pagos } \\
\text { Diseñar empaque para } \\
\text { recordación de la marca. }\end{array}$ & $\begin{array}{l}\text { Gerente de } \\
\text { Operaciones y } \\
\text { de Producción } \\
\text { Gerente de } \\
\text { Producción }\end{array}$ & & $\begin{array}{l}\text { Establecer nuevos } \\
\text { medios de pago vía } \\
\text { internet. } \\
\text { Mantener política de } \\
\text { responsabilidad social }\end{array}$ & $\begin{array}{l}\text { Analizar } \\
\text { resultados de las } \\
\text { promociones } \\
\text { diseñadas para } \\
\text { compras por } \\
\text { medios digitales. }\end{array}$ & \\
\hline
\end{tabular}


Tabla 64

Cronograma 2021 de Cada Iniciativa y sus Responsables de la Perspectiva Cliente Propuestas para Incas Jewelry SAC

\begin{tabular}{|c|c|c|c|c|}
\hline Iniciativa & $\begin{array}{c}\text { Responsabl } \\
\mathrm{e}\end{array}$ & Ene -21 & Mar -21 & Dic -21 \\
\hline $\begin{array}{l}\text { Participación en ferias que } \\
\text { tengas más afluencia de } \\
\text { público y que el costo de } \\
\text { ingreso sea factible re } \\
\text { recuperar. }\end{array}$ & $\begin{array}{l}\text { Gerente de } \\
\text { Operaciones }\end{array}$ & $\begin{array}{l}\text { Evaluar la cantidad de visitas de nuevos } \\
\text { clientes a partir de la participación en } \\
\text { una feria. } \\
\text { Evaluar las ventas originadas por la } \\
\text { participación en una feria. }\end{array}$ & & $\begin{array}{l}\text { Evaluar desempeño de } \\
\text { las acciones }\end{array}$ \\
\hline $\begin{array}{l}\text { Visitar empresas y ofrecer lo } \\
\text { productos }\end{array}$ & $\begin{array}{l}\text { Gerente de } \\
\text { Operaciones }\end{array}$ & $\begin{array}{l}\text { Registrar a Incas Jewelry como } \\
\text { proveedor formal de las empresas a las } \\
\text { cuales se les vende. } \\
\text { Servicio de fotografía para publicar } \\
\text { imágenes de calidad }\end{array}$ & $\begin{array}{l}\text { Preparar promociones a los clientes } \\
\text { frecuentes de estas empresas para } \\
\text { fidelizarlos. }\end{array}$ & $\begin{array}{l}\text { Servicio de fotografía } \\
\text { para publicar imágenes } \\
\text { de calidad }\end{array}$ \\
\hline $\begin{array}{l}\text { Establecer procesos de } \\
\text { atención al cliente }\end{array}$ & $\begin{array}{l}\text { Gerente de } \\
\text { Operaciones }\end{array}$ & $\begin{array}{l}\text { Establecer contratos con algunos } \\
\text { artesanos que puedan hacer } \\
\text { correcciones o reparaciones simples } \\
\text { como parte de la garantía de Incas } \\
\text { Jewelry. }\end{array}$ & $\begin{array}{l}\text { Reducir la cantidad de atenciones } \\
\text { simples en la tienda virtual. } \\
\text { A través de los medios digitales } \\
\text { mantener contacto con los clientes. }\end{array}$ & $\begin{array}{l}\text { Evaluar desempeño de } \\
\text { las acciones }\end{array}$ \\
\hline $\begin{array}{l}\text { Realizar encuestas luego de } \\
\text { cada transacción. }\end{array}$ & $\begin{array}{l}\text { Gerente de } \\
\text { Tienda }\end{array}$ & $\begin{array}{l}\text { Evaluar las acciones que se toman a } \\
\text { partir de la información de las } \\
\text { encuestas. }\end{array}$ & & \\
\hline $\begin{array}{l}\text { Definir promociones para } \\
\text { incentivar al cliente a utiliza } \\
\text { medios electrónicos en sus } \\
\text { pagos }\end{array}$ & $\begin{array}{l}\text { Gerente de } \\
\text { Operaciones } \\
\text { y de } \\
\text { Producción }\end{array}$ & $\begin{array}{l}\text { Implementar acciones de marketing } \\
\text { verde. }\end{array}$ & Mantener publicidad. & \\
\hline $\begin{array}{l}\text { Diseñar empaque para } \\
\text { recordación de la marca. }\end{array}$ & $\begin{array}{l}\text { Gerente de } \\
\text { Producción }\end{array}$ & & $\begin{array}{l}\text { Continuar con las promociones que } \\
\text { hayan tenido mejor respuesta y } \\
\text { rentabilidad para la empresa. }\end{array}$ & \\
\hline
\end{tabular}




\section{Tabla 65}

Cronograma 2022 de Cada Iniciativa y sus Responsables de la Perspectiva Cliente propuestas para Incas Jewelry SAC

\begin{tabular}{|c|c|c|c|c|c|}
\hline Iniciativa & Responsable & Ene -22 & Feb -22 & Mar -22 & Dic -22 \\
\hline $\begin{array}{l}\text { Participación en ferias que } \\
\text { tengas más afluencia de } \\
\text { público y que el costo de } \\
\text { ingreso sea factible re } \\
\text { recuperar. }\end{array}$ & $\begin{array}{l}\text { Gerente de } \\
\text { Operaciones }\end{array}$ & $\begin{array}{l}\text { Continuar con la participación en las } \\
\text { ferias que hayan resultado más } \\
\text { rentable para la empresa desde el } \\
\text { punto de vista de } \\
\text { inversión/ganancia. }\end{array}$ & & & $\begin{array}{l}\text { Evaluar } \\
\text { desempeño } \\
\text { de las } \\
\text { acciones }\end{array}$ \\
\hline $\begin{array}{l}\text { Visitar empresas y ofrecer } \\
\text { lo productos }\end{array}$ & $\begin{array}{l}\text { Gerente de } \\
\text { Operaciones }\end{array}$ & $\begin{array}{l}\text { Servicio de fotografía para publicar } \\
\text { imágenes de calidad }\end{array}$ & $\begin{array}{l}\text { Crear un portal exclusivo para los } \\
\text { clientes de estas empresas con precios } \\
\text { diferenciados y promociones } \\
\text { especiales. }\end{array}$ & & $\begin{array}{l}\text { Servicio } \\
\text { de } \\
\text { fotografía } \\
\text { para } \\
\text { publicar } \\
\text { imágenes } \\
\text { de calidad }\end{array}$ \\
\hline $\begin{array}{l}\text { Establecer procesos de } \\
\text { atención al cliente }\end{array}$ & $\begin{array}{l}\text { Gerente de } \\
\text { Operaciones }\end{array}$ & & & $\begin{array}{l}\text { Establecer contratos con } \\
\text { motorizados que puedan } \\
\text { recoger y entregar }\end{array}$ & $\begin{array}{l}\text { Evaluar } \\
\text { desempeño } \\
\text { de las }\end{array}$ \\
\hline $\begin{array}{l}\text { Realizar encuestas luego } \\
\text { de cada transacción. }\end{array}$ & $\begin{array}{l}\text { Gerente de } \\
\text { Tienda }\end{array}$ & $\begin{array}{l}\text { Participar como empresa en } \\
\text { encuestas reconocidas que miden a } \\
\text { las empresas más queridas y }\end{array}$ & & $\begin{array}{l}\text { productos vendidos o } \\
\text { reparados. }\end{array}$ & acciones \\
\hline $\begin{array}{l}\text { Definir promociones para } \\
\text { incentivar al cliente a } \\
\text { utiliza medios electrónicos } \\
\text { en sus pagos }\end{array}$ & $\begin{array}{l}\text { Gerente de } \\
\text { Operaciones y } \\
\text { de Producción }\end{array}$ & reconocidas. & $\begin{array}{l}\text { Establecer mecanismos para que los } \\
\text { clientes tradicionales que solo compran } \\
\text { en tienda inicien su experiencia de } \\
\text { compra a través de medios digitales. }\end{array}$ & & \\
\hline $\begin{array}{l}\text { Diseñar empaque para } \\
\text { recordación de la marca. }\end{array}$ & $\begin{array}{l}\text { Gerente de } \\
\text { Producción }\end{array}$ & $\begin{array}{l}\text { Medir el impacto en el mercado de } \\
\text { la responsabilidad social asumida } \\
\text { por la empresa. }\end{array}$ & & & \\
\hline
\end{tabular}


Tabla 66

Cronograma 2019 de Cada Iniciativa y sus Responsables de la Perspectiva Interna Propuestas para Incas Jewelry SAC

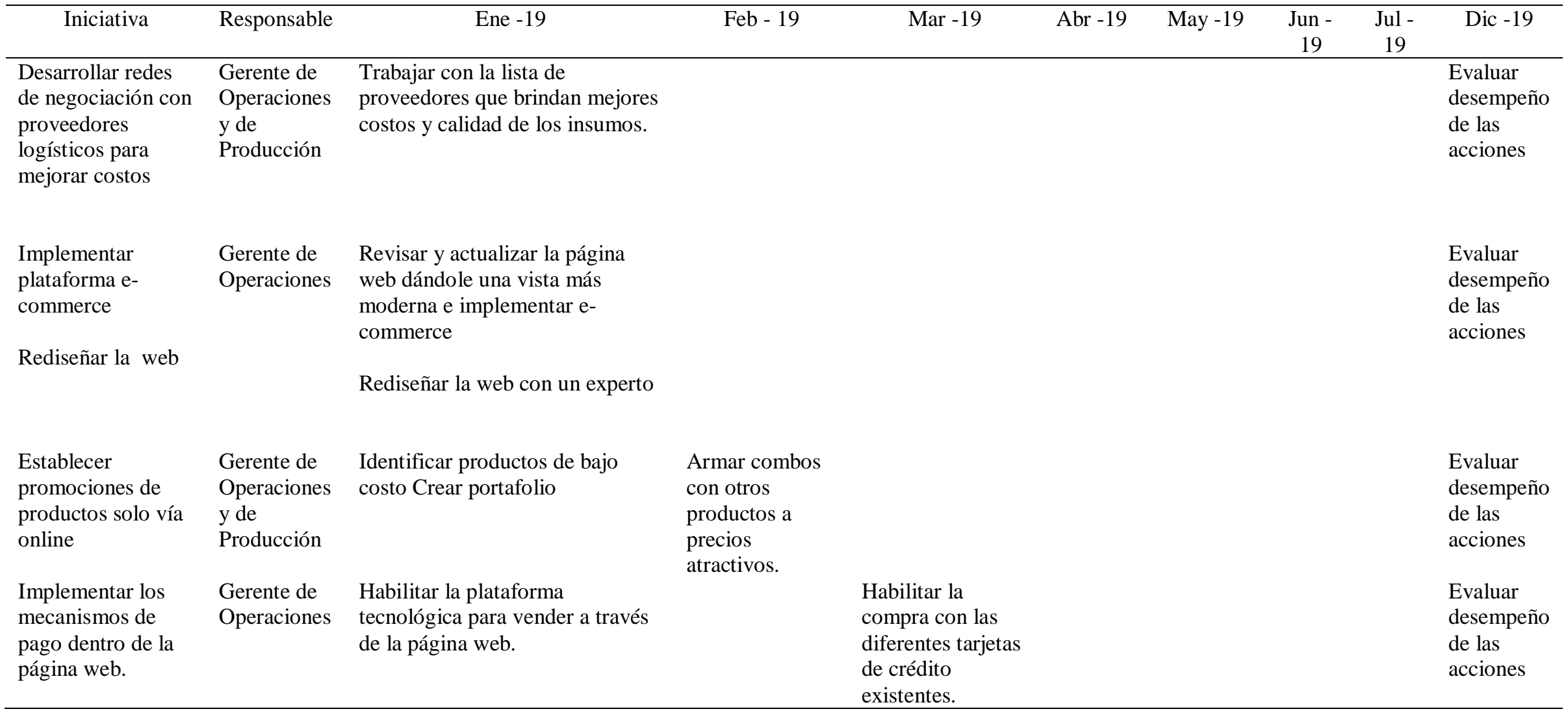


Tabla 67

Cronograma 2020 de Cada Iniciativa y sus Responsables de la Perspectiva Interna Propuestas para Incas Jewelry SAC

\begin{tabular}{|c|c|c|c|c|c|c|c|c|c|c|}
\hline Iniciativa & Responsable & Ene -20 & Feb - 20 & Mar -20 & Abr -20 & May -20 & Jun -20 & Jul -20 & $\begin{array}{l}\text { Ago - } \\
20\end{array}$ & Dic -20 \\
\hline $\begin{array}{l}\text { Desarrollar redes de } \\
\text { negociación con } \\
\text { proveedores logísticos } \\
\text { para mejorar costos }\end{array}$ & $\begin{array}{l}\text { Gerente de } \\
\text { Operaciones } \\
\text { y de } \\
\text { Producción }\end{array}$ & $\begin{array}{l}\text { Tener un cronograma de } \\
\text { compras por volumen. }\end{array}$ & & & & & & & & $\begin{array}{l}\text { Evaluar } \\
\text { desempeño } \\
\text { de las } \\
\text { acciones }\end{array}$ \\
\hline $\begin{array}{l}\text { Establecer compras al } \\
\text { por mayor para obtener } \\
\text { mejores precios }\end{array}$ & & $\begin{array}{l}\text { Trabajar con planificación de } \\
\text { demanda estacional. }\end{array}$ & & & & & & & & \\
\hline $\begin{array}{l}\text { Implementar } \\
\text { plataforma e- } \\
\text { commerce }\end{array}$ & $\begin{array}{l}\text { Gerente de } \\
\text { Operaciones }\end{array}$ & & $\begin{array}{l}\text { Afiliarse con las } \\
\text { principales instituciones } \\
\text { financieras para brindar } \\
\text { mayores facilidades de } \\
\text { pago al cliente. }\end{array}$ & & & & & & & $\begin{array}{l}\text { Evaluar } \\
\text { desempeño } \\
\text { de las } \\
\text { acciones }\end{array}$ \\
\hline Rediseñar la web & & & $\begin{array}{l}\text { Analizar las transacciones } \\
\text { de compra realizadas en la } \\
\text { página web }\end{array}$ & & & & & & & \\
\hline $\begin{array}{l}\text { Establecer } \\
\text { promociones de } \\
\text { productos solo vía } \\
\text { online }\end{array}$ & $\begin{array}{l}\text { Gerente de } \\
\text { Operaciones } \\
\text { y de } \\
\text { Producción }\end{array}$ & & $\begin{array}{l}\text { Analizar las ventas } \\
\text { obtenidas producto de las } \\
\text { promociones. }\end{array}$ & & & & & & & \\
\hline $\begin{array}{l}\text { Implementar los } \\
\text { mecanismos de pago } \\
\text { dentro de la página } \\
\text { web. }\end{array}$ & $\begin{array}{l}\text { Gerente de } \\
\text { Operaciones }\end{array}$ & $\begin{array}{l}\text { Medir los volúmenes de } \\
\text { compra por tarjeta. }\end{array}$ & & & & & & & & $\begin{array}{l}\text { Evaluar } \\
\text { desempeño } \\
\text { de las } \\
\text { acciones }\end{array}$ \\
\hline
\end{tabular}


Tabla 68

Cronograma 2021 de Cada Iniciativa y sus Responsables de la Perspectiva Interna Propuestas para Incas Jewelry SAC

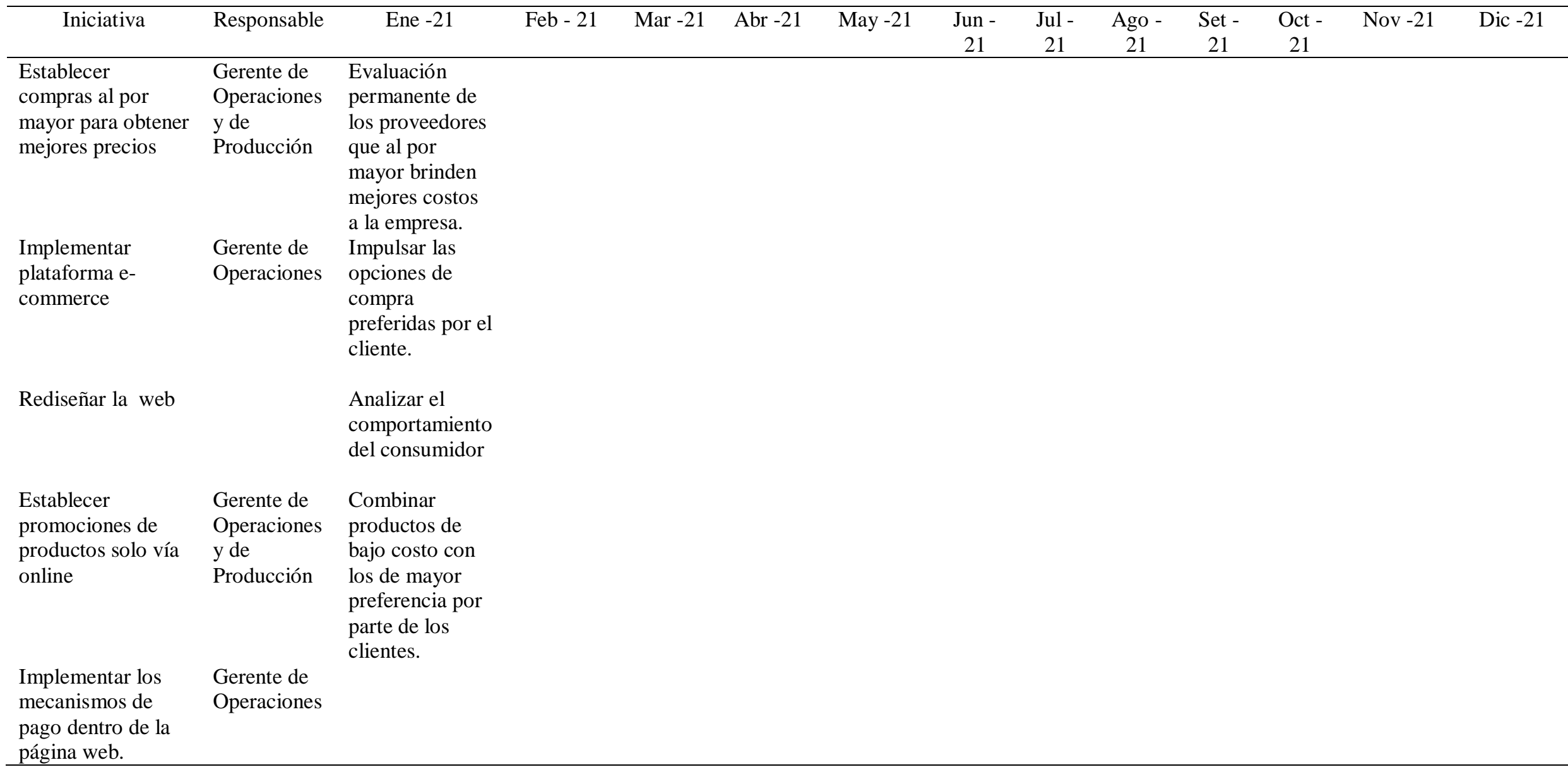


Tabla 69

Cronograma 2022 de Cada Iniciativa y sus Responsables de la Perspectiva Interna Propuestas para Incas Jewelry SAC

\begin{tabular}{|c|c|c|c|c|c|c|c|c|c|c|c|c|c|}
\hline Iniciativa & Responsable & Ene -22 & Feb - 22 & Mar -22 & Abr -22 & May -22 & $\begin{array}{c}\text { Jun - } \\
22\end{array}$ & $\begin{array}{c}\text { Jul - } \\
22\end{array}$ & $\begin{array}{c}\text { Ago - } \\
22\end{array}$ & $\begin{array}{c}\text { Set - } \\
22\end{array}$ & $\begin{array}{c}\text { Oct - } \\
22\end{array}$ & Nov -22 & Dic -22 \\
\hline $\begin{array}{l}\text { Desarrollar redes } \\
\text { de negociación con } \\
\text { proveedores } \\
\text { logísticos para } \\
\text { mejorar costos }\end{array}$ & $\begin{array}{l}\text { Gerente de } \\
\text { Operaciones } \\
\text { y de } \\
\text { Producción }\end{array}$ & $\begin{array}{l}\text { Renegociar } \\
\text { anualmente } \\
\text { las } \\
\text { condiciones } \\
\text { contractuales } \\
\text { con los } \\
\text { proveedores. }\end{array}$ & & & & & & & & & & & \\
\hline $\begin{array}{l}\text { Implementar } \\
\text { plataforma e- } \\
\text { commerce }\end{array}$ & $\begin{array}{l}\text { Gerente de } \\
\text { Operaciones }\end{array}$ & $\begin{array}{l}\text { Implementar } \\
\text { analytics } \\
\text { para medir el } \\
\text { ticket de } \\
\text { compra y los } \\
\text { perfiles del } \\
\text { consumidor } \\
\text { de medios } \\
\text { digitales. }\end{array}$ & & & & & & & & & & & \\
\hline
\end{tabular}


Tabla 70

Cronograma 2019 de Cada Iniciativa y sus Responsables de la Perspectiva Aprendizaje Propuestas para Incas Jewelry SAC

\begin{tabular}{|c|c|c|c|c|c|c|c|c|c|c|c|c|c|}
\hline Iniciativa & Responsable & Ene -19 & Feb - 19 & Mar -19 & Abr -19 & May -19 & $\begin{array}{c}\text { Jun - } \\
19\end{array}$ & $\begin{array}{c}\text { Jul - } \\
19\end{array}$ & $\begin{array}{c}\text { Ago - } \\
19\end{array}$ & $\begin{array}{c}\text { Set - } \\
19\end{array}$ & $\begin{array}{c}\text { Oct - } \\
19\end{array}$ & Nov -19 & Dic -19 \\
\hline $\begin{array}{l}\text { Capacitar a todo el } \\
\text { personal de la } \\
\text { empresa acerca } \\
\text { del comercio } \\
\text { electrónico y a la } \\
\text { fuerza de ventas }\end{array}$ & $\begin{array}{l}\text { Gerente } \\
\text { General }\end{array}$ & $\begin{array}{l}\text { Realizar una } \\
\text { evaluación } \\
\text { de } \\
\text { competencias } \\
\text { a todo el } \\
\text { personal de } \\
\text { la empresa. }\end{array}$ & $\begin{array}{l}\text { Identificar las } \\
\text { fortalezas y } \\
\text { las } \\
\text { oportunidades } \\
\text { de mejora por } \\
\text { rol. }\end{array}$ & $\begin{array}{l}\text { Establecer } \\
\text { un plan de } \\
\text { capacitación } \\
\text { para cada } \\
\text { empleado } \\
\text { para } \\
\text { fortalecer a } \\
\text { la empresa. }\end{array}$ & & & & & & & & & \\
\hline
\end{tabular}

Tabla 71

Cronograma 2020 de Cada Iniciativa y sus Responsables de la Perspectiva Aprendizaje Propuestas para Incas Jewelry SAC

\begin{tabular}{|c|c|c|c|c|c|c|c|c|c|c|c|c|c|}
\hline Iniciativa & Responsable & Ene -20 & Feb - 20 & Mar -20 & Abr -20 & May -20 & $\begin{array}{c}\text { Jun - } \\
20 \\
\end{array}$ & $\begin{array}{c}\text { Jul - } \\
20 \\
\end{array}$ & $\begin{array}{c}\text { Ago - } \\
20\end{array}$ & $\begin{array}{l}\text { Set - } \\
20\end{array}$ & $\begin{array}{c}\text { Oct - } \\
20\end{array}$ & Nov -20 & Dic -20 \\
\hline $\begin{array}{l}\text { Capacitar a todo el } \\
\text { personal de la } \\
\text { empresa acerca del } \\
\text { comercio } \\
\text { electrónico y a la } \\
\text { fuerza de ventas }\end{array}$ & $\begin{array}{l}\text { Gerente } \\
\text { General }\end{array}$ & & & & & & & & & & & & \\
\hline
\end{tabular}


Tabla 72

Cronograma 2021 de Cada Iniciativa y sus Responsables de la Perspectiva Aprendizaje Propuestas para Incas Jewelry SAC

\begin{tabular}{|c|c|c|c|c|c|c|c|c|c|c|c|c|c|}
\hline Iniciativa & Responsable & Ene -21 & Feb - 21 & Mar -21 & Abr -21 & May -21 & $\begin{array}{c}\text { Jun - } \\
21\end{array}$ & $\begin{array}{c}\text { Jul - } \\
21\end{array}$ & $\begin{array}{c}\text { Ago - } \\
21\end{array}$ & $\begin{array}{c}\text { Set - } \\
21\end{array}$ & $\begin{array}{c}\text { Oct - } \\
21\end{array}$ & Nov -21 & Dic -21 \\
\hline $\begin{array}{l}\text { Capacitar a todo el } \\
\text { personal de la } \\
\text { empresa acerca del } \\
\text { comercio } \\
\text { electrónico y a la } \\
\text { fuerza de ventas }\end{array}$ & $\begin{array}{l}\text { Gerente } \\
\text { General }\end{array}$ & $\begin{array}{l}\text { Todo el personal de } \\
\text { la empresa } \\
\text { independientemente } \\
\text { del rol debe tener } \\
\text { conocimiento sobre } \\
\text { el negocio y los } \\
\text { principales } \\
\text { productos. }\end{array}$ & & & & & & & & & & & \\
\hline
\end{tabular}




\section{Capítulo X: Evaluación}

En este capítulo se analizaron los datos históricos de la empresa otorgados por personal interno. Los datos relacionados a los ingresos y egresos de la empresa Incas Jewelry SAC no estaban registrados en ningún sistema o aplicación de Excel. Se tuvo que proceder a levantar toda la información escrita en los cuadernos para poder construir los estados financieros, los balances, estado de pérdidas y ganancias y flujo de caja de efectivo.

\subsection{Evaluación Cualitativa}

Se realizó la proyección de las estrategias que se pretende aplicar con la intención de generar rentabilidad de la empresa. Teniendo como premisa que desde el año 2014, fecha que inició la operación del negocio, hasta el 2018 ha tenido bajos ingresos por su bajo volumen de venta. En vista que existe un buen margen de venta en la industria de la joyería, es que se pretende darle una oportunidad de sobrevivencia a la empresa incrementado exponencialmente los volúmenes de venta.

\subsubsection{Criterios de evaluación}

En 2015, D’Alessio señaló que para establecer los criterios de evaluación de las estrategias seleccionadas se utilizará la Matriz Rumelt (MR).

- Consistencia: Una estrategia no debe presentar objetivos ni políticas inconsistentes.

- Consonancia: Una estrategia debe representar una respuesta adaptativa al entorno externo y a los cambios críticos que ocurren en él.

- Ventaja: Una estrategia debe proveer la creación y/o mantenimiento de las ventajas competitivas en áreas selectas de actividad.

- Factibilidad: Una estrategia no debe originar un sobrecosto en los recursos disponibles ni crear sub-problemas sin solución.

\subsubsection{Comparación de la estrategia con los criterios}

Como D’Alessio (2015) señaló "Luego de seleccionar las estrategias como resultado de todo el análisis previo en otras matrices se aplica la matriz de Rumelt, siguiendo los siguientes pasos": (p.305) (ver Tabla 73).

- Identificar las estrategias del MCPE

- Evaluar cada estrategia de acuerdo con los criterios de consistencia, consonancia, factibilidad y ventaja.

- Seleccionar solo aquellas que pasen todas las pruebas 
Tabla 73

Matriz de Rumelt

\begin{tabular}{|c|c|c|c|c|c|}
\hline Estrategias específicas & Consistencia & Consonancia & Ventaja & Factibilidad & Se acepta \\
\hline $\begin{array}{l}\text { Estrategia de penetración de } \\
\text { mercado }\end{array}$ & $\mathrm{Si}$ & $\mathrm{Si}$ & $\mathrm{Si}$ & $\mathrm{Si}$ & $\mathrm{Si}$ \\
\hline $\begin{array}{l}\text { Estrategia de desarrollo de } \\
\text { producto }\end{array}$ & $\mathrm{Si}$ & $\mathrm{Si}$ & SI & No & $\mathrm{Si}$ \\
\hline $\begin{array}{l}\text { Estrategia de desarrollo de } \\
\text { mercado }\end{array}$ & $\mathrm{Si}$ & No & $\mathrm{Si}$ & No & No \\
\hline $\begin{array}{l}\text { Estrategia de diversificación } \\
\text { relacionada }\end{array}$ & $\mathrm{Si}$ & $\mathrm{Si}$ & $\mathrm{Si}$ & No & No \\
\hline $\begin{array}{l}\text { Estrategia de recorte de gastos a } \\
\text { través de la reducción de costos }\end{array}$ & $\mathrm{Si}$ & $\mathrm{Si}$ & No & $\mathrm{Si}$ & No \\
\hline Estrategia de desinversión & $\mathrm{Si}$ & $\mathrm{Si}$ & No & No & No \\
\hline Estrategia de liquidación & $\mathrm{Si}$ & $\mathrm{Si}$ & No & No & No \\
\hline
\end{tabular}

Nota. Tomado de Proceso Estratégico (p.305), por F. D’Alessio, 2015, Lima, Perú: Pearson 2013 por Pearson Educación de Perú S.A.

\subsection{Evaluación Financiera de la Estrategia}

Luego de haber analizado las estrategias y acciones propuestas para revertir los malos resultados de la empresa, se construyen los estados financieros con la situación actual y la proyección de los estados financieros como resultado de las estrategias aplicadas. Se muestra el cuadro donde se calculan los costos de implementación de las estrategias sugeridas y los resultados de su ejecución.

\subsubsection{Estado de resultados (situación actual y con la nueva estrategia)}

En esta tabla consolidamos la información de pérdidas y ganancias desde el año 2015 que es cuando inició operaciones la empresa hasta 2018 (ver Tabla 74). Luego se muestra el año donde se inicia la aplicación de estrategias y la visibilidad de los primeros resultados que es en el 2019. Finamente se completa con la proyección de las pérdidas y ganancias del 2019 al 2022 (ver Tabla 75). Como resultado de los estados financieros mostrados podemos apreciar que el gran problema de la empresa es el volumen de ventas. Los costos no impactan sustancialmente en el negocio ya que la rentabilidad por pieza vendida era bastante buena. Lo que se requería era incrementar las ventas a través de diversas acciones específicas como establecer sueldo variable para los vendedores, ampliación de canales de venta, expansión comercial a través de los medios electrónicos y participación en ferias.

\subsubsection{Balance general (situación actual y con la nueva estrategia)}

A partir del Balance General de Apertura del año 2018 que es el momento donde se constituye la empresa y se registran los activos y pasivos de la empresa (ver Tabla 76). 
Esta empresa inicia sus operaciones con inversiones 100\% propias de los socios sin recurrir a ningún financiamiento bancario. Luego se muestran los balances de los años 2015 al 2018 donde se aprecia cual ha sido el comportamiento del negocio durante estos años con una pérdida constante y acumulada. A partir del 2019 donde inicia la ejecución de las estrategias seleccionadas ya los balances reflejan los primeros resultados y el incremento gradual de los volúmenes de ventas hasta el año 2022 (ver Tabla 77).

Tabla 74

Estado de Resultados - Situación Actual sin estrategia

\begin{tabular}{lcccc}
\hline \multirow{2}{*}{ Estado de Resultados (En soles) } & \multicolumn{5}{c}{ Año Base } \\
\cline { 2 - 5 } & 2015 & 2016 & 2017 & 2018 \\
\hline Ingresos por ventas & $49,235.00$ & $49,169.21$ & $63,457.30$ & $82,003.20$ \\
Costo de ventas & $24,617.50$ & $21,672.43$ & $28,579.40$ & $21,421.50$ \\
\hline Utilidad Bruta & $24,617.50$ & $27,496.78$ & $34,877.90$ & $60,581.70$ \\
\hline Gastos de Administración & $45,423.99$ & $45,684.20$ & $42,697.90$ & $38,885.00$ \\
Gastos de Venta & $2,418.00$ & $3,974.80$ & $7,580.35$ & $25,972.00$ \\
Utilidad de operación & $-23,224.49$ & $-22,162.22$ & $-15,400.35$ & $-4,275.30$ \\
Gastos financieros & & - & - & - \\
Utilidad antes de Impuestos & -23224.49 & -22162.218 & -15400.348 & -4275.3 \\
I.S.R. (Imp. Sobre la renta) & 2872 & 144 & 2571 & 1148.41 \\
P.T.U. (Participación de los & 0 & 0 & 0 & 0 \\
trabajadores en las utilidades) & 0 & 0 & 0 & -5423.71 \\
\hline Utilidad Neta & -26096.49 & -22306.218 & -17971.348 & 0 \\
\hline Depreciaciones & & 0 & 0 & 0 \\
Amortizaciones & & 0 & 0 & -5423.71 \\
Flujos de efectivo & -26096.49 & -22306.218 & -17971.348 & \\
\hline
\end{tabular}

Tabla 75

Estado de Resultados - Con la nueva estrategia

\begin{tabular}{lcccc}
\hline \multirow{2}{*}{ Estado de Resultados (En soles) } & \multicolumn{5}{c}{ Años proyectados } \\
\cline { 2 - 5 } Ingresos por ventas & 2019 & 2020 & 2021 & 2022 \\
\cline { 2 - 5 } Costo de ventas & $246,000.00$ & 334000 & 466000 & 612000 \\
\hline Utilidad Bruta & $61,500.00$ & 83500 & 116500 & 153000 \\
\hline Gastos de Administración & $184,500.00$ & $250,500.00$ & $349,500.00$ & $459,000.00$ \\
Gastos de Venta & $37,241.00$ & 37241 & 37241 & 37241 \\
\hline Utilidad de operación & $63,982.00$ & 85482 & 64427 & 15222 \\
\hline Gastos financieros & $83,277.00$ & $127,777.00$ & $247,832.00$ & $406,537.00$ \\
\hline Utilidad antes de Impuestos & - & & & \\
\hline I.S.R. (Imp. Sobre la renta) & 83277 & 127777 & 247832 & 406537 \\
P.T.U. (Participación de los & 3170.5 & 4342 & 6058 & 7956 \\
trabajadores en las utilidades) & 0 & 0 & 0 & \\
\hline Utilidad Neta & 80106.5 & 123435 & 241774 & 398581 \\
\hline Depreciaciones & 0 & 0 & 0 & 0 \\
Amortizaciones & 0 & 0 & 0 & 0 \\
\hline Flujos de efectivo & 80106.5 & 123435 & 241774 & 398581 \\
\hline
\end{tabular}


Tabla 76

Balance General - Situación Actual

\begin{tabular}{|c|c|c|c|c|c|}
\hline & \multicolumn{4}{|c|}{ Histórico } & \multirow{2}{*}{$\begin{array}{l}\text { Base } \\
2018\end{array}$} \\
\hline & $\begin{array}{c}2014 \\
\text { (Apertura) } \\
\end{array}$ & 2015 & 2016 & 2017 & \\
\hline Activo corriente & \multicolumn{5}{|c|}{ Activo } \\
\hline Caja y Bancos & S/. 0.00 & S/. 1,667.61 & S/. 8,789.00 & S/. $10,869.86$ & S/. $12,744.64$ \\
\hline Inventarios & S/. $28,047.00$ & S/. $32,116.03$ & S/. $33,108.60$ & S/. $34,732.78$ & S/. 41,571.00 \\
\hline Total activo corriente & S/. 28,047.00 & S/. 33,783.64 & S/. $41,897.60$ & S/. 45,602.64 & S/. 54,315.64 \\
\hline \multicolumn{6}{|l|}{ Activo No Corriente o Fijo } \\
\hline Muebles y enseres & S/. $13,100.00$ & S/. $13,100.00$ & S/. $13,100.00$ & S/. $13,100.00$ & S/. $13,100.00$ \\
\hline Maquinarias y Equipo & S/. 3,853.00 & S/. 3,853.00 & $\mathrm{S} / .3,853.00$ & $\mathrm{~S} / .3,853.00$ & S/. $3,853.00$ \\
\hline $\begin{array}{l}\text { Menos depreciación } \\
\text { acumulada }\end{array}$ & S/. 0.00 & $-\mathrm{S} / .1,695.30$ & -S/. 3,390.60 & $-\mathrm{S} / .5,085.90$ & $-\mathrm{S} / .6,781.20$ \\
\hline Total activo no corriente & S/. $16,953.00$ & S/. $15,257.70$ & S/. $13,562.40$ & S/. $11,867.10$ & S/. $10,171.80$ \\
\hline \multicolumn{6}{|l|}{ Otros activos } \\
\hline Inversiones permanentes & S/. 0.00 & S/. 0.00 & S/. 0.00 & S/. 0.00 & S/. 0.00 \\
\hline Intangibles - neto & S/. 0.00 & S/. 0.00 & S/. 0.00 & S/. 0.00 & S/. 0.00 \\
\hline \multicolumn{6}{|l|}{ Otros Activos a Largo } \\
\hline Plazo & S/. 0.00 & S/. 0.00 & S/. 0.00 & S/. 0.00 & S/. 0.00 \\
\hline Total otros activos & S/. 0.00 & $\mathrm{~S} / .0 .00$ & S/. 0.00 & S/. 0.00 & $\mathrm{~S} / .0 .00$ \\
\hline Total activo & S/. $45,000.00$ & S/. 49,041.34 & S/. $55,460.00$ & S/. $57,469.74$ & S/. $64,487.44$ \\
\hline \multicolumn{6}{|l|}{ Pasivo y patrimonio } \\
\hline \multicolumn{6}{|l|}{ Pasivo corriente } \\
\hline Obligaciones financieras & S/. 0.00 & S/. 0.00 & S/. 0.00 & S/. 0.00 & S/. 0.00 \\
\hline \multicolumn{6}{|l|}{ Cuentas x Pagar a } \\
\hline Proveedores & S/. 0.00 & S/. 0.00 & $\mathrm{~S} / .0 .00$ & S/. 0.00 & S/. 0.00 \\
\hline Pasivo laboral & S/. 0.00 & S/. 0.00 & S/. 0.00 & S/. 0.00 & S/. 3,000.00 \\
\hline Pasivo fiscal & S/. 0.00 & S/. 0.00 & S/. 0.00 & S/. 0.00 & S/. 0.00 \\
\hline Dividendos x Pagar & S/. 0.00 & S/. 0.00 & S/. 0.00 & S/. 0.00 & S/. 0.00 \\
\hline Otros pasivos corrientes & S/. 0.00 & $\mathrm{~S} / .0 .00$ & S/. 0.00 & S/. 0.00 & S/. 0.00 \\
\hline Total pasivo corriente & S/. 0.00 & S/. 0.00 & S/. 0.00 & S/. 0.00 & S/. 3,000.00 \\
\hline \multicolumn{6}{|l|}{ Pasivos a Largo Plazo } \\
\hline Obligaciones financieras & $\mathrm{S} / .0 .00$ & $\mathrm{~S} / .0 .00$ & S/. 0.00 & S/. 0.00 & S/. 0.00 \\
\hline Pasivo laboral & S/. 0.00 & $\mathrm{~S} / .0 .00$ & S/. 0.00 & S/. 0.00 & S/. 0.00 \\
\hline Impuesto diferido & $\mathrm{S} / .0 .00$ & S/. 0.00 & S/. 0.00 & S/. 0.00 & $\mathrm{~S} / .0 .00$ \\
\hline Deudas con Socios & $\mathrm{S} / .0 .00$ & S/. $30,137.83$ & S/. 58,862.71 & S/. $78,843.80$ & S/. $88,285.21$ \\
\hline Otros Pasiv de Larg Plazo & S/. 0.00 & S/. 0.00 & S/. 0.00 & S/. 0.00 & S/. 0.00 \\
\hline \multicolumn{6}{|l|}{ Total Pasivos a Largo } \\
\hline Plazo & S/. 0.00 & S/. $30,137.83$ & S/. 58,862.71 & S/. $78,843.80$ & S/. $88,285.21$ \\
\hline \multicolumn{6}{|l|}{ Patrimonio } \\
\hline Capital pagado & S/. 45,000.00 & S/. 45,000.00 & S/. 45,000.00 & S/. 45,000.00 & S/. $45,000.00$ \\
\hline Capital adicional & S/. 0.00 & S/. 0.00 & S/. 0.00 & S/. 0.00 & S/. 0.00 \\
\hline Reserva legal & S/. 0.00 & $\mathrm{~S} / .0 .00$ & S/. 0.00 & S/. 0.00 & S/. 0.00 \\
\hline Otras reservas & S/. 0.00 & S/. 0.00 & S/. 0.00 & S/. 0.00 & S/. 0.00 \\
\hline Revalorizaciones & S/. 0.00 & $\mathrm{~S} / .0 .00$ & S/. 0.00 & S/. 0.00 & $\mathrm{~S} / .0 .00$ \\
\hline Result de Ejerc Ant & S/. 0.00 & S/. 0.00 & $-\mathrm{S} / .26,096.49$ & $-\mathrm{S} / .48,402.71$ & $-S / .66,374.06$ \\
\hline Result del Ejerc Actual & S/. 0.00 & $-\mathrm{S} / .26,096.49$ & $-\mathrm{S} / .22,306.22$ & $-\mathrm{S} / .17,971.35$ & $-S / .5,423.71$ \\
\hline Total patrimonio & S/. $45,000.00$ & S/. 18,903.51 & $-\mathrm{S} / .3,402.71$ & $-\mathrm{S} / .21,374.06$ & $-\mathrm{S} / .26,797.77$ \\
\hline Total pasivo & S/. $45,000.00$ & S/. 49,041.34 & S/. 55,460.00 & S/. 57,469.74 & S/. $64,487.44$ \\
\hline
\end{tabular}


Tabla 77

Balance General - Con Estrategia

\begin{tabular}{|c|c|c|c|c|}
\hline \multirow{2}{*}{ Balance General } & \multicolumn{4}{|c|}{ Proyección } \\
\hline & 2019 & 2020 & 2021 & 2022 \\
\hline \multicolumn{5}{|l|}{ ACTIVO } \\
\hline \multicolumn{5}{|l|}{ Activo Corriente } \\
\hline Caja y Bancos & S/. $92,851.14$ & S/. $106,371.05$ & S/. $222,664.83$ & S/. $375,445.83$ \\
\hline \multicolumn{5}{|l|}{ Cuentas x Cobrar } \\
\hline Inventarios & S/. 72,567.00 & S/. $111,264.90$ & S/. $180,767.00$ & $\mathrm{~S} / .427,567.00$ \\
\hline \multicolumn{5}{|l|}{ Gastos Pagados x Anticipado } \\
\hline Total Activo Corriente & S/. $168,418.14$ & S/. 217,635.95 & S/. $403,431.83$ & S/. $803,012.83$ \\
\hline \multicolumn{5}{|l|}{ Activo No Corriente o Fijo } \\
\hline \multicolumn{5}{|l|}{ Terreno } \\
\hline \multicolumn{5}{|l|}{ Inmuebles } \\
\hline Muebles y enseres & S/. $13,100.00$ & S/. $13,100.00$ & S/. $23,100.00$ & S/. $23,100.00$ \\
\hline Maquinarias y Equipo & $\mathrm{S} / .3,853.00$ & S/. $3,853.00$ & S/. 3,853.00 & S/. 3,853.00 \\
\hline Menos Depreciación Acumulada & -S/. 8,476.50 & $-\mathrm{S} / .10,171.80$ & $-\mathrm{S} / .11,867.10$ & $-\mathrm{S} / .12,867.10$ \\
\hline Total Activo No Corriente & S/. $8,476.50$ & S/. 6,781.20 & S/. $15,085.90$ & S/. $14,085.90$ \\
\hline \multicolumn{5}{|l|}{ Otros Activos } \\
\hline Inversiones Permanentes & S/. 0.00 & S/. 0.00 & S/. 0.00 & S/. 0.00 \\
\hline Intangibles - Neto & S/. 0.00 & S/. 0.00 & S/. 0.00 & S/. 0.00 \\
\hline Otros Activos a Largo Plazo & S/. 0.00 & S/. 0.00 & S/. 0.00 & S/. 0.00 \\
\hline Total Otros Activos & S/. 0.00 & S/. 0.00 & S/. 0.00 & S/. 0.00 \\
\hline TOTAL ACTIVO & S/. $173,894.64$ & S/. 224,417.15 & S/. 418,517.73 & S/. $817,098.73$ \\
\hline \multicolumn{5}{|l|}{ PASIVO Y PATRIMONIO } \\
\hline \multicolumn{5}{|l|}{ Pasivo Corriente } \\
\hline Obligaciones Financieras & S/. 0.00 & S/. 0.00 & S/. 0.00 & S/. 0.00 \\
\hline Cuentas x Pagar a Proveedores & S/. 0.00 & S/. 0.00 & S/. 0.00 & S/. 0.00 \\
\hline Pasivo Laboral & S/. 0.00 & S/. 0.00 & S/. 0.00 & S/. 0.00 \\
\hline Pasivo Fiscal & S/. 0.00 & S/. 0.00 & S/. 0.00 & S/. 0.00 \\
\hline Dividendos x Pagar & S/. 0.00 & S/. 0.00 & S/. 0.00 & S/. 0.00 \\
\hline Otros Pasivos Corrientes & S/. 0.00 & S/. 0.00 & S/. 0.00 & S/. 0.00 \\
\hline Total Pasivo Corriente & S/. 0.00 & S/. 0.00 & S/. 0.00 & S/. 0.00 \\
\hline \multicolumn{5}{|l|}{ Pasivos a Largo Plazo } \\
\hline Obligaciones Financieras & S/. 0.00 & S/. 0.00 & S/. 0.00 & S/. 0.00 \\
\hline Pasivo Laboral & S/. 0.00 & S/. 0.00 & S/. 0.00 & S/. 0.00 \\
\hline Impuesto Diferido & S/. 0.00 & S/. 0.00 & S/. 0.00 & S/. 0.00 \\
\hline Deudas con Socios & S/. $120,585.91$ & S/. $47,673.42$ & S/. 0.00 & S/. 0.00 \\
\hline Otros Pasivos de Largo Plazo & S/. 0.00 & S/. 0.00 & S/. 0.00 & S/. 0.00 \\
\hline Total Pasivos a Largo Plazo & S/. $120,585.91$ & S/. $47,673.42$ & S/. 0.00 & S/. 0.00 \\
\hline \multicolumn{5}{|l|}{ Patrimonio } \\
\hline Capital Pagado & $\mathrm{S} / .45,000.00$ & $\mathrm{~S} / .45,000.00$ & S/. $45,000.00$ & $\mathrm{~S} / .45,000.00$ \\
\hline Capital Adicional & S/. 0.00 & S/. 0.00 & S/. 0.00 & S/. 0.00 \\
\hline Reserva Legal & S/. 0.00 & S/. 0.00 & S/. 0.00 & S/. 0.00 \\
\hline Otras Reservas & S/. 0.00 & S/. 0.00 & S/. 0.00 & S/. 0.00 \\
\hline Revalorizaciones & S/. 0.00 & S/. 0.00 & S/. 0.00 & S/. 0.00 \\
\hline Resultados de Ejercicios Anteriores & $-\mathrm{S} / .71,797.77$ & S/. 8,308.73 & S/. $131,743.73$ & S/. $373,517.73$ \\
\hline Resultado del Ejercicio Actual & $\mathrm{S} / .80,106.50$ & S/. $123,435.00$ & S/. $241,774.00$ & S/. $398,581.00$ \\
\hline Total Patrimonio & S/. $53,308.73$ & S/. $176,743.73$ & S/. 418,517.73 & S/. $817,098.73$ \\
\hline TOTAL PASIVO & S/. $173,894.64$ & S/. $224,417.15$ & S/. $418,517.73$ & S/. 817,098.73 \\
\hline
\end{tabular}




\subsubsection{Flujo de efectivo (situación actual y con la nueva estrategia)}

En este subcapítulo se aprecia el flujo de efectivo desde la constitución de la empresa hasta el año 2018. Cabe mencionar que no aparece nada en el Flujo de Caja de Operación es porque la única compra de activos se realizó al momento de constituir la empresa y eso fue en Diciembre de 2014. Luego de eso no hubo compra de activos en dicho período. Asimismo a pesar de que la empresa tenía perdidas según la deducción entre los ingresos y los egresos, año tras año los socios inyectaban aportes propios para iniciar en positivo las operaciones del siguiente año (ver Tabla 78). Se aprecia el flujo de efectivo anual proyectado del 2019 al 2022 que refleja el nuevo rumbo del negocio alcanzando los niveles de ingreso deseados e incluyendo las inversiones en estrategias (ver Tabla 79). El año 2019 se define como clave ya que inicia la ejecución de las estrategias propuestas por eso la importancia de mostrar mes a mes el comportamiento del flujo de caja de dicho año (ver Tabla 80).

Tabla 78

Flujo de Efectivo - Situación Actual

\begin{tabular}{lcccc}
\hline & FC 2015 & FC 2016 & FC 2017 & FC 2018 \\
\hline Ingresos operativos (cobranzas ventas) & 49235.00 & 49169.21 & 63457.30 & 82003.20 \\
Egresos operativos (sueldos, pago proveed, pago & & & & \\
impuestos impuesto a la renta) & 75331.49 & 71475.43 & 81428.65 & 87426.91 \\
Flujo de Caja Operación & -26096.49 & -22306.22 & -17971.35 & -5423.71 \\
Activo fijo & - & - & - & - \\
Intangible & - & - & - & - \\
Capital de trabajo & - & - & - & - \\
Flujo de Caja Inversiones & 0 & 0 & 0 & 0 \\
FCO - FCI = Flujo de Caja Libre o Flujo de Caja & & & & \\
Económico & -26096.49 & -22306.22 & -17971.35 & -5423.71 \\
\hline Saldo Inicial & 0 & 1667.61 & 8789 & 10869.86 \\
\hline Saldo Final & -26096.49 & -20638.61 & -9182.35 & 5446.15 \\
\hline
\end{tabular}

Tabla 79

Flujo de Efectivo - Con Estrategia

\begin{tabular}{|c|c|c|c|c|}
\hline & FC 2019 & FC 2020 & FC 2021 & FC 2022 \\
\hline Ingresos operativos (cobranzas ventas) & 246000.00 & 334000.00 & 466000.00 & 612000.00 \\
\hline $\begin{array}{l}\text { Egresos operativos (sueldos, pago } \\
\text { proveed, pago impuestos a la renta) }\end{array}$ & 165893.50 & 210565.00 & 224226.00 & 213419.00 \\
\hline Flujo de Caja Operación & 80106.50 & 123435.00 & 241774.00 & 398581.00 \\
\hline $\begin{array}{l}\text { Activo fijo } \\
\text { Intangible } \\
\text { Capital de trabajo }\end{array}$ & & & 10000 & \\
\hline Flujo de Caja Inversiones & 0 & 0 & 10000 & 0 \\
\hline $\begin{array}{l}\text { FCO - FCI = Flujo de Caja Libre o Flujo } \\
\text { de Caja Económico }\end{array}$ & 80106.50 & 123435.00 & 231774.00 & 398581.00 \\
\hline Saldo Inicial & 12744.64 & 92851.14 & 106371.052 & 222664.83 \\
\hline Saldo Final & 92851.14 & 216286.14 & 338145.05 & 621245.83 \\
\hline
\end{tabular}




\section{Tabla 80}

Flujo de Efectivo Mensual - Con Estrategia

\begin{tabular}{|c|c|c|c|c|c|c|c|c|c|c|c|c|}
\hline & Ene-19 & Feb-19 & Mar-19 & Abr-19 & May-19 & Jun-19 & Jul-19 & Ago-19 & Set-19 & Oct-19 & Nov-19 & Dic-19 \\
\hline $\begin{array}{l}\text { Ingresos operativos (cobranzas } \\
\text { ventas) }\end{array}$ & 17500 & 18500 & 19500 & 20500 & 21500 & 22500 & 20000 & 20000 & 20000 & 21000 & 22000 & 23000 \\
\hline $\begin{array}{l}\text { Egresos operativos (sueldos, pago } \\
\text { proveed, pago impuestos económico } \\
\text { sin deuda) }\end{array}$ & 8806 & 9065.5 & 9290.5 & 9557.5 & 59768.5 & 10083.5 & 9426 & 9426 & 9426 & 9689 & 11140 & 10215 \\
\hline Flujo de Caja Operación & 8694 & 9434.5 & 10209.5 & 10942.5 & -38268.5 & 12416.5 & 10574 & 10574 & 10574 & 11311 & 10860 & 12785 \\
\hline Activo fijo & - & - & - & - & - & - & - & - & - & - & - & - \\
\hline Intangible & - & - & - & - & - & - & - & - & - & - & - & -- \\
\hline Capital de trabajo & - & - & - & - & - & - & - & - & - & - & - & -- \\
\hline Flujo de Caja Inversiones & 0 & 0 & 0 & 0 & 0 & 0 & 0 & 0 & 0 & 0 & 0 & 0 \\
\hline $\begin{array}{l}\text { FCO - FCI = Flujo de Caja Libre o } \\
\text { Flujo de Caja Económico }\end{array}$ & 8694 & 9434.5 & 10209.5 & 10942.5 & -38268.5 & 12416.5 & 10574 & 10574 & 10574 & 11311 & 10860 & 12785 \\
\hline Saldo Inicial & 12744.64 & 21438.64 & 30873.14 & 41082.64 & 52025.14 & 13756.64 & 26173.14 & 36747.14 & 47321.14 & 57895.14 & 69206.14 & 80066.14 \\
\hline Saldo Final & 21438.64 & 30873.14 & 41082.64 & 52025.14 & 13756.64 & 26173.14 & 36747.14 & 47321.14 & 57895.14 & 69206.14 & 80066.14 & 92851.14 \\
\hline
\end{tabular}




\subsubsection{Evaluación Financiera}

Finalmente apreciamos la evaluación del proyecto a partir del año 2019 en el cual se aplican las estrategias seleccionadas. Se utilizó el VAN como indicador financiero para determinar la viabilidad de este nuevo rumbo que la empresa está siguiendo. Se tomó en cuenta una Tasa de Descuento de 8\% (MEF, 2018) para el cálculo del VAN en principio pero finalmente por el riesgo del negocio se usó una tasa de 20\%. Cabe recalcar también que este proyecto no ha recurrido a ningún financiamiento bancario ni cuando empezó a operar ni para la ejecución de las nuevas estrategias. La inversión totalizada de la ejecución de las estrategias es de S/. 186,975 que será desembolsado progresivamente durante esos cuatro años desde el 2019 al 2022. Toda la inversión es propia de los socios lo cual se refleja en el buen resultado de este indicador (ver Tabla 81).

Tabla 81

Evaluación Financiera - VAN

\begin{tabular}{l} 
VAN $=-186975+\frac{80106.50}{1.2}+\frac{123435.00}{1.44}+\frac{231774.00}{1.728}+\frac{398581.00}{2.0736}$ \\
VAN $=-186975+66755.4167+85718.75+134128.472+192216.917$ \\
\hline VAN $=$ S/.291,844.56
\end{tabular}




\section{Capítulo XI: Conclusiones y Recomendaciones}

\subsection{Conclusiones}

- Con el desarrollo de este proyecto logramos construir en estados financieros la real situación del negocio que no existía previamente por no contar con registros formales de toda la información de la empresa.

- Se comprueba que un plan estratégico sirve para ejecutar un trabajo a largo plazo y a todo nivel con el fin de reorientar una pequeña empresa cuya rentabilidad iba decreciendo dramáticamente.

- Este proyecto demuestra también que no solo la reducción de costos es la estrategia fundamental en un plan estratégico ya que esta empresa al tener un buen margen de ventas por producto lo que requería era incrementar sustancialmente su volumen de ventas.

- Después de analizar las diversas matrices de formulación de estrategias se concluye que la estrategia más viable es la de penetración de mercado dado que es necesario buscar aumentar la participación del mercado para los productos que actualmente vende la tienda a través de estrategias de marketing, como la implementación del ecommerce.

- Las empresas familiares como estás siempre requieren que profesionales calificados se involucren en el negocio para ayudar a identificar competencias y corregir procesos erróneos. 


\subsection{Recomendaciones}

- Se establece de ahora en adelante que todo movimiento y operación de la empresa debe quedar registrado en los respectivos libros contables para tener control total sobre la utilidad de la empresa.

- Si bien la empresa nació sin un plan de negocios y al aplicarse ahora este plan estratégico al 2022 se recomienda volver a hacer un nuevo plan en dicho momento para alinear los objetivos del negocio.

- Resulta clave el objetivo de implementar la plataforma de comercio electrónico ya que permite aumentar cantidad de clientes, ampliar los canales de atención y vender al exterior para lograr el gran objetivo del aumento exponencial de los ingresos.

- No descuidar el buen margen por producto que tiene actualmente la empresa con la aparición de nuevos procesos comerciales.

- Implementar un plan de gobierno corporativo en la empresa que regule el funcionamiento del negocio para evitar decidir aisladamente sin pensar en los objetivos generales y respetando la política genera del negocio.

- Se recomienda implementar un adecuado plan de sucesión familiar que permita mantener el plan de crecimiento del negocio más allá de la segunda generación ya que se suele perder el liderazgo, el compromiso y conocimiento del negocio. Este plan de sucesión debe establecer que si la siguiente generación no se encuentra apta para continuar con la operación del negocio se abrirá el ingreso de profesionales fuera de la familia pero con la capacidad para mejorar el desarrollo de la empresa siempre bajo la mirada familiar.

- Se debe crear un Comité Familiar que debe resolver los problemas familiares y los conflictos internos que pudieran afectar el desarrollo del negocio. Este Comité Familiar también se encargará de supervisar la labor de los profesionales que participan en la dirección de la empresa sin ser parte de la familia. 


\section{Referencias}

Artesanos y Empresas Seleccionadas por Promperú, Mincetur. (18 de diciembre 2017). Gestión, p.26.

Atribución, C. C. (2015). Platería en el Virreinato del Perú. Lima, Perú: Creative Commons Atribución.

BID. (2017). Escenarios Futuros. Atlantic Council.

Cavalieri, G. (6 de diciembre del 2017). Visita del Presidente de la Confederación Mundial de Joyería CIBJO. Gestión, p. 3.

Chan W. \& Mauborgne R. (2004). La estrategia del Océano Azul. Bogotá, Colombia: Editorial Norma.

D’Alessio, F. (2015). Proceso Estratégico. Lima, Perú: Pearson Educación de Perú.S.A.

David, F. (2013). Conceptos de Administración Estratégica. México, D.F., México: Pearson Education.

Drucker, P. (2006). Management y Liderazgo. México, D.F., México: Pearson Education

Durance, P \& Godet, M (2011). Selección de los Métodos para la Construcción de los Escenarios de Futuro. La Prospective Estrategica para las Empresas y Territorios. 2, p 32.

Durance, P \& Godet, M. (2015). Prospectiva Estratégica. Paris, Francia: Laboratoire d'Investigation Prospective et Stratégique .

Exportaciones de joyerías peruanas crecieron $8 \%$ entre enero y julio. Gestión. (17 diciembre de 2016). Gestión, p. 7

Franklin, E. B. (2009). Organización de Empresas. Mexico: McGraw-Hill Intercamericana Editores.

INEI. (2014). Proyecciones PBI. Recuperado 1 de mayo del 2018, de https://www.inei.gob.pe/biblioteca-virtual/boletines/pbi-trimestral/1/

INEI. (2018). Dinámica de Empresas y PBI. Lima, Perú. Recuperado 1 de mayo del 2018 de https://www.inei.gob.pe/biblioteca-virtual/boletines/pbi-trimestral/1/

INEI. (2018). Perú: Altas de empresas en el IV Trimestre de 2017, según actividad económica. Recuperado 1 de mayo del 2018 de https://www.inei.gob.pe/biblioteca-virtual/boletines/pbi-trimestral/1/

INEI. (2018). PERÚ: Stock Y Variación Neta de empresas por trimestre, 2015-17.

Recuperado 1 de mayo del 2018 de https://www.inei.gob.pe/bibliotecavirtual/boletines/pbi-trimestral/1/ 
Jiménez, E. (6 de enero del 2018). Demografía empresarial en el 2017. Presionados a emprender. Diario "El Comercio", p. 20

Kaplan, R., \& Norton, D. (2000). The Balance Scorecard. Barcelona, España: Gestión 2000

Keller, P. K. (2009). Marketing Management. New Jersey, New York: Pearson Education, Inc., Upper Saddle River.

Majluf, A. H. (1998). Estrategias para el Liderazgo Competitivo. Barcelona, España: Granica.

MEF. (2018). Actualización de la Tasa Social de Descuento. Recuperado 22 de octubre del 2018 de https://www.mef.gob.pe/es/inversion-publica-sp-21787/184instrumentos-metodologicos/4490-social

Mercado Internacional Joyeria Final. Promperu. (17 abril del 2018). Promperu.

Mercado peruano de joyería 'mueve' unos US\$ 57 millones al año. (8 de diciembre de 2015). Gestión, p. 5

Nota Semanal del BCRP. (2 de enero de 2018). Gestión, p. 2.

Pallancata, H. M. (2018). Producción en toneladas metrica de plata. Pallancata, Perú.

Perez J. Adex (2 julio 2017). El presidente del Comité de Joyería y Orfebrería de Adex señala. Gestión

Peruano, D. E. (2008). Normas Legales. Lima, Perú: Diario El Peruano.

Reyes, A. G. (2010). El Arte de la Orfebrería y Joyería. Santiago, Chile. Editorial Universitaria 


\section{Apéndice}

Apéndice A1

\section{Entrevista en Profundidad al Gerente General}

Entrevistado
Cargo
Empresa
Fecha
Lugar
Objetivo
Pregunta A8. ¿Qué expectativa tiene con este
proyecto de Plan Estratégico para su empresa?
Pregunta C2. ¿Cuántos empleados tienen la
empresa actual?

Pregunta A1 ¿Cuál era su expectativa al iniciar este negocio?

Pregunta a. Principal función que realiza en el cargo

Pregunta B1 ¿Qué opina de los productos sustitutos que se ofrece a los clientes? Y pregunta B3. ¿Qué opina del poder de negociación de los consumidores?

Pregunta A7. ¿Qué expectativa tiene con este proyecto de Plan Estratégico para su empresa? Y Pregunta D4 ¿De qué depende las compras de insumos o mercadería de la tienda?

Pregunta A3 ¿Piensa mantener la estructura familiar del negocio o planea profesionalizarlo insertando empleados fuera de la familia?

La mayoría de las preguntas

Pregunta D4. ¿De qué dependen las compras de insumos o mercadería de la tienda?

Le mencionaré algunos factores claves de éxito de una joyería? Indicarme si es fortaleza mayor, menor, debilidad menor o mayor. (Esta pregunta fue dictada)

Pregunta A1. ¿Cuál era su expectativa al iniciar este negocio?
Mg. Víctor Raúl Gutiérrez Divizia

Gerente General

Incas Jewelry S.A.C

$12 / 03 / 18$

San Miguel

Conocer la percepción de la empresa y cómo ve a la industria de la joyería en Lima.

Utilizada en el capítulo 2.1 Antecedentes de la empresa

Utilizada en el capítulo 2.2 Descripción del Negocio

Utilizada en el capítulo 2.3.1 Tabla 2. Etapa de Crecimiento

Utilizada en el capítulo 2.4. Estructura organizacional actual de la empresa

Utilizada en el capítulo 4.2 Impacto en clientes / proveedores de cada una de las variables del entorno

Utilizada en el capítulo 4.3 Efecto en la empresa de cada una de las variables del entorno, en la tabla trabajada.

5.2 Descripción de las cinco fuerzas competitivas de la industria

Utilizada en el capítulo 6.1. Descripción de las actividades de la cadena de valor de la empresa: Administración de recursos humanos

Utilizada en el capítulo 6.4. Competencia de la empresa

Utilizada en el capítulo 5.5 matriz MPC y capítulo 6.3. Benchmarking, para ponderar los factores claves de éxito

Utilizada en el capítulo 6.5. Identificación y Determinación de las Ventajas Competitivas de la Empresa

\section{Entrevistador:}

\section{Guía de la Entrevista en Profundidad al Gerente General}

Entrevistado:

Fecha:

Buenos días/tardes, mi nombre es Olyenka Gutiérrez. Quiero agradecerle por el tiempo que nos está brindando y quisiera pedirle por favor responder con toda confianza las preguntas, ya que la información que usted nos otorgue será estrictamente confidencial.

Objetivo del estudio 
Conocer la percepción de la empresa y cómo ve a la industria de la joyería en Lima.

Preguntas
a. Datos personales
b. Nombre completo y cargo:
c. Antiguiedad en el cargo como Gerente General y Representante Legal:
d. Principal función que realiza en el cargo:

A. Gerencia (20 minutos)

1. ¿Cuál era su expectativa al iniciar este negocio?

2. ¿A este punto del tiempo que puede decir de lo que esperaba lo ha logrado?

3. ¿Piensa mantener la estructura familiar del negocio o planea profesionalizarlo insertando empleados fuera de la familia?

4. ¿Cómo ve la competencia directa de la empresa considerando otros negocios del mismo tamaño?

5. ¿Tiene planes de exportar sus productos o prefiere en este momento consolidar la operación local?

6. ¿Por qué cree que pasa esto?

7. ¿Considera que a la legislación existente para las pymes favorece o no a su empresa?

8. ¿Qué expectativa tiene con este proyecto de Plan Estratégico para su empresa?

B. Fuerzas internas (15 minutos)

1. ¿Qué opina de los productos sustitutos que se ofrece a los clientes?

2. ¿Cómo ve la entrada potencial de nuevos competidores?

3. ¿Qué opina del poder de negociación de los consumidores?

4. ¿Qué opina del poder de negociación de los proveedores?

5. ¿Cree que exista rivalidad entre empresas competidoras?

C. Recursos Humanos (15 minutos)

1. ¿Cuánta experiencia tiene manejando equipos de trabajo?

2. ¿Cuántos empleados tiene la empresa actual?

3. ¿Se reúne con frecuencia con sus empleados?

4. ¿A qué retos los ha enfrentado?

5. ¿Hay disposición por parte de ellos?

6. ¿Firman algún acta de acuerdos?

7. ¿Qué tipo de incentivos y penalidades ha formulado?

D. Financiera (8 minutos)

1. ¿Qué tipo de control financiero lleva en la empresa?

2. ¿Cómo controla el ingreso y salida de caja?

3. ¿Qué tipos de registro lleva para dicho control?

4. ¿De qué depende las compras de insumos o mercadería de la tienda?

Adicionales:

Le mencionaré algunos factores claves de éxito de una joyería. Indicarme si es fortaleza mayor, menor, debilidad menor o mayor. (Esta pregunta fue dictada) 


\begin{tabular}{|l|l|}
\hline \multicolumn{1}{|c|}{ Factores claves de éxito } & $\begin{array}{l}\text { 4 Fortaleza mayor } \\
\text { 3 Fortaleza menor } \\
\text { 2 Debilidad menor } \\
\text { 1 Debilidad mayor }\end{array}$ \\
\hline Publicidad & \\
\hline Calidad de productos & \\
\hline Estilo & \\
\hline Competitividad de precios & \\
\hline Reconocimiento de marca & \\
\hline Lealtad del cliente & \\
\hline Variedad de productos & \\
\hline Confiabilidad & \\
\hline Capacidad de producción & \\
\hline Comercio electrónico & \\
\hline Servicio postventa & \\
\hline Promociones & \\
\hline Canales de distribución & \\
\hline Puntualidad & \\
\hline
\end{tabular}

Ahora bien, para terminar ¿Cuál es su expectativa para la empresa de aquí a cinco años? En cinco años debe estar consolidado en Lima, y debe haber incursionado en la exportación de plata, artesanía, piedras y tejidos.

Finalmente, ¿Algún otro comentario que quiera agregar? ¡Muchas Gracias!

Datos Básicos

Empresa

Ubicación

Nombre

Cargo del entrevistado :

Firma

DNI

Fecha

Muchas gracias! 


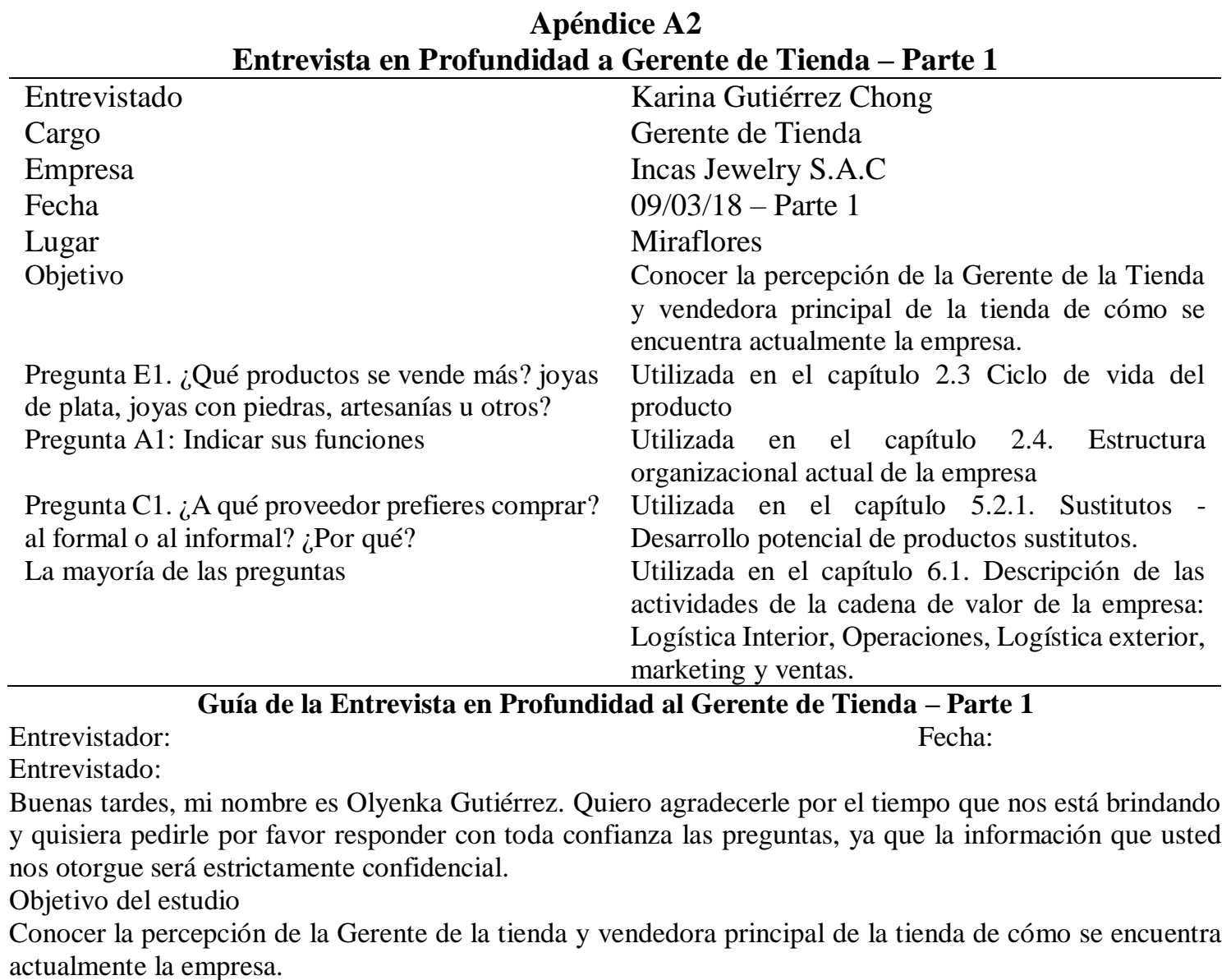

Preguntas

A. Conocimiento de sus funciones y cómo ve a Incas Jewelry $\quad$ (10 min.)

1. Indicar sus funciones

2. ¿Qué debilidades consideras que tiene la empresa en este momento?

3. ¿En comparación al inicio de la empresa a este punto de tiempo, que consideras que la empresa mejoró y que no mejoró?

B. Conocimiento de la empresa (17 $\mathrm{min})$

a) Entrada potencial de nuevos competidores ( $3 \mathrm{~min}$ )

1. ¿Cómo ves la competencia directa?

b) Poder de negociación de los consumidores ( 5 min)

1. ¿Qué promoción consideras que la empresa podría utilizar para atraer más clientes?

2. ¿Qué promoción consideras que la empresa podría utilizar para incrementar el ticket de venta de tus clientes? (ticket de venta es la cantidad que te compran en la visita)

c) Poder de negociación de los proveedores $(3 \mathrm{~min}$ )

1. ¿A qué proveedor prefieres comprar? al formal o al informal? ¿Por qué?

d) Rivalidad entre empresas competidoras (3 min)

1. Consideras que otras empresas del rubro utilizan herramientas comerciales que ustedes no tienen? Cuáles son?

e) Desarrollo potencial de Productos Sustitutos (3 min)

1. ¿Qué productos se vende más? joyas de plata, joyas con piedras, artesanías u otros?

Ahora bien, para terminar ¿Cuál es su expectativa para la empresa de aquí a cinco años?

Finalmente, ¿Algún otro comentario que quiera agregar?

Datos Básicos

Empresa

Ubicación

Nombre

Cargo del entrevistado :

Firma

DNI

Fecha

Muchas gracias! 


Entrevista en Profundidad a
Entrevistado
Cargo
Empresa
Fecha
Lugar
Objetivo
Pregunta C2. ¿Cree que su empresa invierte lo
suficiente para mantener sus contactos? ¿Qué
razones lo llevaría a Ud. a invertir más en las
relaciones de su empresa con otros actores del
mercado?
Pregunta C1. ¿De qué manera su empresa se
relaciona con los diversos actores en el
mercado (clientes,
competidores, otros)
Pregunta C3. Qué tipo de información le
proporciona cada red de contacto (clientes,
proveedores, competidores, otros)?
Pregunta Ba1: ¿Conoce quiénes son sus
principales competidores?; Pregunta Bb2.
¿Cómo logra Ud. Mantener una relación
duradera y rentable con sus clientes? Y
pregunta Bc2. ¡Cree que su empresa invierte
lo suficiente para mantener sus contactos?
Pregunta C1: ¿De qué manera su empresa se
relaciona con los diversos actores en el
mercado?; Pregunta C3. ¿Qué tipo de
información le proporciona cada red de
contactos; Pregunta B3: ¿Cómo logra Ud.
mantener una relación duradera y rentable con
sus clientes?

Utilizada en el capítulo 5.2. Descripción las cinco fuerzas competitivas de la industria

Utilizada en el capítulo 5.2.1. Sustitutos Desarrollo potencial de productos sustitutos.

Utilizada en el capítulo 5.5. en el análisis de la tabla de Matriz de Perfil Competitivo

Utilizada en el capítulo 6.1. Descripción de las actividades de la cadena de valor de la empresa

\author{
Karina Gutiérrez Chong \\ Gerente de Tienda \\ Incas Jewelry S.A.C \\ 18/04/18 - Parte 2 \\ Miraflores \\ estigar como el propietario de las pequeñas \\ empresa.
}

Utilizada en el capítulo 4.2 Impacto en Clientes / Proveedores de cada una de las Variables del Entorno

Utilizada en el capítulo 6.1. Descripción de las
actividades de la cadena de valor de la
empresa

Entrevistador:

\title{
Guía de la Entrevista en Profundidad al Gerente de Tienda Parte 2
}

Entrevistado:

Fecha:

Introducción

Buenos días/tardes, mi nombre es Olyenka Gutiérrez. Quiero agradecerle por el tiempo que nos está brindando y quisiera pedirle por favor responder con toda confianza las preguntas, ya que la información que usted nos otorgue será estrictamente confidencial.

\section{OBJETIVO DEL ESTUDIO}

Investigar como el propietario de las pequeñas empresas establece redes de contactos para su empresa.

\section{PREGUNTAS}

A. Conocimiento de la empresa (5 min.)

1. ¿A qué se dedica su negocio?

2. ¿Cuánto tiempo de experiencia y cuánto de conocimiento considera Ud que tiene en este rubro?

B. Conocimiento de la red de contactos

a) Competidores $(7 \mathrm{~min})$

(25 $\min )$ 
1. ¿Conoce quiénes son sus principales competidores? Cómo obtiene información sobre ellos?

2. ¿Qué le motivaría intercambiar información con los competidores para tomar ciertas decisiones comerciales?, si lo ha hecho cuál es su experiencia?

b) Clientes $(8 \mathrm{~min})$

1. ¿Quiénes son sus clientes?

2. ¿Qué tipo de relación mantiene con sus clientes?

3. Cómo logra Ud. mantener una relación duradera y rentable con sus clientes?

c) Redes de contacto (10 min)

1. ¿De qué manera su empresa se relaciona con los diversos actores en el mercado (clientes, proveedores, competidores, otros)?

2. ¿Cree que su empresa invierte lo suficiente para mantener sus contactos? ¿Qué razones lo llevaría a Ud. a invertir más en las relaciones de su empresa con otros actores del mercado?

3. Qué tipo de información le proporciona cada red de contacto (clientes, proveedores, competidores, otros)?

Datos Básicos

\section{Empresa}

Ubicación

Nombre

Cargo del entrevistado :

Firma

DNI

Fecha

Muchas gracias! 


\begin{tabular}{l} 
Entrevista en Profundidad \\
\hline Entrevistado \\
Cargo \\
Empresa \\
Fecha \\
Lugar \\
Objetivo \\
Pregunta A1: Indicar sus funciones \\
Pregunta Ba1. ¿Conoce ud acerca de los \\
procesos que manejan sus competidores? Y \\
Pregunta Ba2. ¿Consideras que otras \\
empresas del rubro utilizan herramientas \\
comerciales que ustedes no tienen? Cuáles \\
son?; Pregunta Bc1. Desde el punto de vista \\
de alianzas comerciales, Con quienes trabajan \\
y de qué forma? Menciónelos.
\end{tabular}

Pregunta B2. ¿Qué le motivaría intercambiar información con los competidores para tomar ciertas decisiones comerciales?, si lo ha hecho cuál es su experiencia?

\title{
péndice $\mathrm{A} 4$
}

\author{
Piero Gutiérrez Chong \\ Gerente de Operaciones \\ Incas Jewelry S.A.C \\ $18 / 04 / 18$ \\ Miraflores \\ Conocer la percepción del Gerente de \\ Operaciones de Incas Jewelry S.A.C de cómo \\ se encuentra actualmente la empresa. \\ Utilizada en el capítulo 2.4. Estructura \\ organizacional actual de la empresa
}

Utilizada en el capítulo 6.1. Descripción de las actividades de la cadena de valor de la empresa

Utilizado en el capítulo 5.2.2 5.2.2. Potenciales - Entrada potencial de nuevos competidores.

\section{Entrevista en profundidad}

\section{Guía de la Entrevista en Profundidad al Gerente de Operaciones}

Entrevistador:

Fecha:

Entrevistado:

Introducción

Buenas tardes, mi nombre es Olyenka Gutiérrez. Quiero agradecerle por el tiempo que nos está brindando y quisiera pedirle por favor responder con toda confianza las preguntas, ya que la información que usted nos otorgue será estrictamente confidencial.

Objetivo del estudio

Conocer la percepción del gerente de Operaciones de Incas Jewelry S.A.C de cómo se encuentra actualmente la empresa.

Preguntas
A. Conocimiento de sus funciones
(15 min.)

1. Indicar sus funciones

2. ¿En comparación al inicio de la empresa a este punto de tiempo, que consideras que la empresa mejoró y que no mejoró?

3. Cuenta con los procesos administrativos de la empresa documentados?

4. Si es así, siempre se cumple o por circunstancias particulares se toma otro flujo sin consultar al GG?

5. ¿Cómo ve a la empresa hoy en consideración a cuando inicio sus operaciones?

B. Conocimiento de la empresa (22 min)

a) Entrada potencial de ingreso de nuevos Competidores $(5 \mathrm{~min}$ )

1. ¿Conoce ud acerca de los procesos que manejan sus competidores?

2. Consideras que otras empresas del rubro utilizan herramientas comerciales que ustedes no tienen? Cuáles son?

b) Poder de Negociación de los consumidores (8 min) 
1. ¿Los procesos de la empresa son flexibles que permiten tomar acciones por circunstancias particulares?

2. ¿Qué debilidades y fortalezas considera que tiene la empresa en este momento?

3. ¿Utiliza la tecnología para operaciones administrativas, logísticas y/o comerciales? Detállelas por favor

c) Poder de negociación de los Proveedores (5 min)

1. Desde el punto de vista de alianzas comerciales, Con quienes trabajan y de qué forma? Menciónelos.

2. ¿Evalúa Ud. las empresas que quieren trabajar con ustedes antes de aceptarlos como tal?

d) Rivalidad entre empresas competidores (2 min)

1. Considera usted que una inversión adicional de un socio externo ayudaría a que la empresa tenga un despegue?

e) Desarrollo potencial de Productos Sustitutos (2 min)

1. ¿Qué criterios evalúa Ud. para proveerse de productos sustitutos?

Ahora bien, para terminar ¿Cuál es su expectativa para la empresa de aquí a cinco años?

Finalmente, ¿Algún otro comentario que quiera agregar?

Datos Básicos

Empresa

Ubicación

Nombre

Cargo del entrevistado :

Firma

DNI

Fecha

Muchas gracias! 


\section{Apéndice A5 \\ Entrevista en Profundidad a Experto en la Industria Ex Director de Exportación de Platería de Mincetur}

Entrevistado
Cargo
Empresa
Fecha
Lugar
Objetivo

Pregunta 11. ¿Existe algún reglamento para las pymes que trabajan con ustedes?

Pregunta 7. ¿Qué considera debe mejorar para incentivar la exportación de la plata peruana?

Pregunta 8. ¿Qué productos sustitutos compiten con la plata en temas de exportación? y pregunta 14. ¿Existe información de tendencias al 2022 sobre la plata peruana?

Pregunta 15. Qué factores claves de éxito considera que la industria de la joyería debería tener? (Se le mostró una lista)
Alejandro Pino Gutiérrez

Ex Director de Exportación de Platería de

Mincetur

$16 / 04 / 18$

La Molina

Conocer sobre la industria de las joyas de plata en el Perú. Y los indicadores que se manifiestan en el mercado.

Utilizado en el capítulo 4.1.2 Análisis Económico. Impuesto y en el capítulo 4.2 Efecto en la empresa. Económico. Impuesto

Utilizado en el capítulo 4.1.2 Análisis Legal. Certificación

Utilizado en el capítulo 4.4 Oportunidades y Amenazas.

Utilizado en el capítulo 5,5 Matriz Perfil Competitivo MPC y en el capítulo 6.3. Benchmarking, para ponderar los factores claves de éxito

\section{Guía de la Entrevista en Profundidad a Experto de la Industria - Ex Director de Exportación de Platería de Mincetur}

Entrevista en profundidad

Entrevistador:

Fecha:

Entrevistado:

Introducción

Buenas tardes, mi nombre es Olyenka Gutiérrez. Quiero agradecerle por el tiempo que nos está brindando y quisiera pedirle por favor responder con toda confianza las preguntas, ya que la información que usted nos otorgue será estrictamente confidencial.

Objetivo del estudio

Conocer sobre la industria de las joyas de plata en el Perú. Y los indicadores que se manifiestan en el mercado.

Preguntas

1. ¿Cuál es su cargo?

2. ¿Cuánto tiempo tiene en el cargo?

3. ¿Qué organismo de gobierno o ministerio supervisa a Prom Perú?

4. ¿Dentro de su responsabilidad esta supervisar la producción y comercialización de plata peruana?

5. ¿Tiene información del porcentaje que tiene la exportación de plata peruana en proporción al total de exportaciones del país? Cuál es?

6. ¿Qué legislación regula la comercialización y exportación de plata peruana?

7. ¿Qué considera debe mejorar para incentivar la exportación de la plata peruana?

8. ¿Qué productos sustitutos compiten con la plata en temas de exportación?

9. ¿Qué herramientas proporciona el gobierno peruano para incentivar a las empresas que producen y comercializan plata peruana?

10. ¿Otorgan algún tipo de financiamiento para las pymes?

11. ¿Existe algún reglamento para las pymes que trabajan con ustedes?

12. ¿De qué manera penalizan a las empresas que incumplen con las normas?

13. ¿Nos podría brindar información estadística sobre la producción, comercialización y exportación de plata peruana en los últimos años?

14. ¿Existe información de tendencias al 2022 sobre la plata peruana?

15. Qué factores claves de éxito considera que la industria de la joyería debería tener? (Se le mostró una lista) 


\begin{tabular}{|l|}
\hline \multicolumn{1}{|c|}{ Factores claves de éxito } \\
\hline Publicidad \\
\hline Calidad de los productos \\
\hline Competitividad de precios \\
\hline Reconocimiento de marca \\
\hline Lealtad del cliente \\
\hline Variedad del producto \\
\hline Capacidad de producción \\
\hline Comercio electrónico \\
\hline Servicio al cliente \\
\hline Promociones \\
\hline Especialización en el sector \\
\hline Nuevos canales de distribución \\
\hline
\end{tabular}

Ahora bien, para terminar ¿Cuál es su expectativa que tiene para la industria de la joyería para las pymes? Finalmente, ¿Algún otro comentario que quiera agregar?

Datos Básicos

Empresa

Ubicación

Nombre

Cargo del entrevistado

Firma

DNI

Fecha

Muchas gracias! 


\begin{tabular}{|c|c|}
\hline \multicolumn{2}{|c|}{$\begin{array}{c}\text { Apéndice A6 } \\
\text { Entrevista en Profundidad a la Competencia - Gerente General Joyas M\&F }\end{array}$} \\
\hline Entrevistado & Luis Manuel Gonzales Vásquez \\
\hline Cargo & Gerente General \\
\hline Empresa & Joyas M\&F \\
\hline Fecha & $09 / 03 / 18$ \\
\hline Lugar & Centro de Lima \\
\hline Objetivo & $\begin{array}{l}\text { Investigar como el propietario de una pequeña } \\
\text { empresa establece redes de contactos para su } \\
\text { empresa. }\end{array}$ \\
\hline Varias respuestas se utilizaron como dato & $\begin{array}{l}\text { Utilizada en el capítulo 5.3. Matriz de } \\
\text { Atractividad de cada una de las cinco fuerzas }\end{array}$ \\
\hline $\begin{array}{l}\text { Pregunta A1: ¿A qué se dedica su negocio?; } \\
\text { Pregunta Bb1. ¿Quiénes son sus clientes? } \\
\text { Pregunta Bb2. ¿Qué tipo de relación mantiene } \\
\text { con sus clientes? Y Pregunta Bb3. ¿Cómo } \\
\text { logra Ud. mantener una relación duradera y } \\
\text { rentable con sus clientes? }\end{array}$ & $\begin{array}{l}\text { Utilizada en el capítulo 5.5. Análisis de la } \\
\text { tabla de Matriz de Perfil Competitivo }\end{array}$ \\
\hline Pregunta Bb1 ¿Quiénes son sus clientes? & $\begin{array}{l}\text { Utilizada en el capítulo 4.1.4. Análisis } \\
\text { Cultural. Estilos de vida }\end{array}$ \\
\hline $\begin{array}{l}\text { Pregunta A3. Le mencionaré algunos factores } \\
\text { claves de éxito de una joyería? Indicarme si es } \\
\text { fortaleza mayor, menor, debilidad menor o } \\
\text { mayor. (Esta pregunta fue dictada) }\end{array}$ & $\begin{array}{l}\text { Utilizado en el capítulo 5,5 Matriz Perfil } \\
\text { Competitivo MPC }\end{array}$ \\
\hline $\begin{array}{l}\text { Pregunta A3. Le mencionaré algunos factores } \\
\text { claves de éxito de una joyería? Indicarme si es } \\
\text { fortaleza mayor, menor, debilidad menor o } \\
\text { mayor. (Esta pregunta fue dictada) }\end{array}$ & $\begin{array}{l}\text { Utilizado en el capítulo } 5,5 \text { Matriz Perfil } \\
\text { Competitivo MPC y en el capítulo } 6.3 \\
\text { Benchmarkting }\end{array}$ \\
\hline
\end{tabular}

\section{Guía de la Entrevista en Profundidad a la Competencia - Gerente General Joyas M\&F ENTREVISTA EN PROFUNDIDAD \\ Entrevistador: \\ Fecha:}

Entrevistado:

Introducción

Buenas tardes, mi nombre es Olyenka Gutiérrez. Quiero agradecerle por el tiempo que nos está brindando y quisiera pedirle por favor responder con toda confianza las preguntas, ya que la información que usted nos otorgue será estrictamente confidencial.

OBJETIVO DEL ESTUDIO

Investigar como el propietario de una pequeña empresa establece redes de contactos para su empresa.

\section{PREGUNTAS}

A. Conocimiento de la empresa (5 min.)

1. ¿A qué se dedica su negocio?

2. ¿Cuánto tiempo de experiencia y cuánto de conocimiento considera Ud que tiene en este rubro?

3. Le mencionaré algunos factores claves de éxito de una joyería? Indicarme si es fortaleza mayor, menor, debilidad menor o mayor. (Esta pregunta fue dictada) 


\begin{tabular}{|l|l|}
\hline \multicolumn{1}{|c|}{ Factores claves de éxito } & $\begin{array}{l}\text { 4 Fortaleza mayor } \\
\text { 3 Fortaleza menor } \\
\text { 2 Debilidad menor } \\
\text { 1 Debilidad mayor }\end{array}$ \\
\hline Publicidad & \\
\hline Calidad de productos & \\
\hline Estilo & \\
\hline Competitividad de precios & \\
\hline Reconocimiento de marca & \\
\hline Lealtad del cliente & \\
\hline Variedad de productos & \\
\hline Confiabilidad & \\
\hline Capacidad de producción & \\
\hline Comercio electrónico & \\
\hline Servicio postventa & \\
\hline Promociones & \\
\hline Canales de distribución & \\
\hline Puntualidad & \\
\hline
\end{tabular}

B. Conocimiento de la red de contactos

(25 min)

a) Competidores (7 min)

1. ¿Conoce quiénes son sus principales competidores? Cómo obtiene información sobre ellos?

2. ¿Qué le motivaría intercambiar información con los competidores para tomar ciertas decisiones comerciales?, si lo ha hecho cuál es su experiencia?

b) Clientes (8 $\mathrm{min})$

1. ¿Quiénes son sus clientes?

2. ¿Qué tipo de relación mantiene con sus clientes?

3. ¿Cómo logra Ud. mantener una relación duradera y rentable con sus clientes?

c) Redes de contacto (10 min)

1. ¿De qué manera su empresa se relaciona con los diversos actores en el mercado (clientes, proveedores, competidores, otros)?

2. ¿Cree que su empresa invierte lo suficiente para mantener sus contactos? ¿Qué razones lo llevaría a Ud. a invertir más en las relaciones de su empresa con otros actores del mercado?

3. ¿Qué tipo de información le proporciona cada red de contacto (clientes, proveedores, competidores, otros)?

\section{Datos Básicos}

$\begin{array}{lll}\text { Empresa } & : & \text { Ubicación: } \\ \text { Cargo del entrevistado } & : & \\ \text { Número de trabajadores en la compañía } & : & \\ \text { Firma } & & : \\ \text { DNI } & : \\ \text { Fecha } & : \\ \text { Muchas gracias! } & \end{array}$


Apéndice A7

Entrevista en Profundidad a la Competencia - Administradora de la Tienda Spondylus

Entrevistado
Cargo
Empresa
Fecha
Lugar
Objetivo

Casi todas las preguntas sirvieron

Pregunta A1: ¿A qué se dedica su negocio?; Pregunta Bc1. ¿Quiénes son sus clientes? Pregunta $\mathrm{Bc} 2$. ¿Qué tipo de relación mantiene con sus clientes? Y Pregunta Bc3. ¿Cómo logra Ud. mantener una relación duradera y rentable con sus clientes?

Pregunta A3. Le mencionaré algunos factores claves de éxito de una joyería? Indicarme si es fortaleza mayor, menor, debilidad menor o mayor. (Esta pregunta fue dictada)

Pregunta A3. Le mencionaré algunos factores claves de éxito de una joyería? Indicarme si es fortaleza mayor, menor, debilidad menor o mayor. (Esta pregunta fue dictada)
Rita Sánchez

Administradora de la Tienda

Spondylus

09/03/18

Av La Mar. Miraflores

Investigar como el propietario de las pequeñas empresas establece redes de contactos para su empresa.

Utilizada en el capítulo 5.2. Descripción las Cinco Fuerzas Competitivas de la Industria

Utilizada en el capítulo 5.5. Análisis de la tabla de Matriz de Perfil Competitivo

Utilizado en el capítulo 5,5 Matriz Perfil Competitivo MPC

Utilizado en el capítulo 5,5 Matriz Perfil Competitivo MPC y en el capítulo 6.3 Benchmarkting

\section{Guía de la Entrevista en Profundidad a la Competencia - Administradora de la Tienda Spondylus}

Entrevista en profundidad

Entrevistador:

Fecha:

Entrevistado:

Introducción

Buenos días, mi nombre es Olyenka Gutiérrez. Quiero agradecerle por el tiempo que nos está brindando y quisiera pedirle por favor responder con toda confianza las preguntas, ya que la información que usted nos otorgue será estrictamente confidencial.

Objetivo del estudio

Investigar como el propietario de las pequeñas empresas establece redes de contactos para su empresa.

Preguntas

A. Conocimiento de la empresa (5 min.)

1. ¿A qué se dedica su negocio?

2. ¿Cuánto tiempo de experiencia y cuánto de conocimiento considera Ud que tiene en este rubro?

3. Le mencionaré algunos factores claves de éxito de una joyería? Indicarme si es fortaleza mayor, menor, debilidad menor o mayor. (Esta pregunta fue dictada) 


\begin{tabular}{|c|c|}
\hline Factores claves de éxito & $\begin{array}{l}4 \text { Fortaleza mayor } \\
3 \text { Fortaleza menor } \\
2 \text { Debilidad menor } \\
1 \text { Debilidad mayor }\end{array}$ \\
\hline Publicidad & \\
\hline Calidad de productos & \\
\hline Estilo & \\
\hline Competitividad de precios & \\
\hline Reconocimiento de marca & \\
\hline Lealtad del cliente & \\
\hline Variedad de productos & \\
\hline Confiabilidad & \\
\hline Capacidad de producción & \\
\hline Comercio electrónico & \\
\hline Servicio postventa & \\
\hline Promociones & \\
\hline Canales de distribución & \\
\hline Puntualidad & \\
\hline
\end{tabular}

B. Conocimiento de la red de contactos

$(25 \mathrm{~min})$

a) Competidores (7 min)

1. ¿Conoce quiénes son sus principales competidores? Cómo obtiene información sobre ellos?

2. ¿Qué le motivaría intercambiar información con los competidores para tomar ciertas decisiones comerciales?, si lo ha hecho cuál es su experiencia?

b) Clientes ( $8 \mathrm{~min})$

1. ¿Quiénes son sus clientes?

2. ¿Qué tipo de relación mantiene con sus clientes?

3. ¿Cómo logra Ud. mantener una relación duradera y rentable con sus clientes?

c) Redes de contacto (10 $\mathrm{min})$

1. ¿De qué manera su empresa se relaciona con los diversos actores en el mercado (clientes, proveedores, competidores, otros)?

2. ¿Cree que su empresa invierte lo suficiente para mantener sus contactos? ¿Qué razones lo llevaría a Ud. a invertir más en las relaciones de su empresa con otros actores del mercado?

3. Qué tipo de información le proporciona cada red de contacto (clientes, proveedores, competidores, otros)?

Datos Básicos

Empresa

Ubicación

Cargo del entrevistado

Número de trabajadores en la compañía

Firma

DNI

Fecha

Muchas gracias! 
Apéndice B1

Cuestionario al Gremio de Artesanos Inscritos en Promperú

\author{
Grupo Entrevistado \\ Cargo \\ Fecha \\ Lugar de la reunión \\ Número de personas que llenaron el \\ cuestionario \\ Objetivo
}

Pregunta 8: ¿Sus productos están certificados?

Pregunta 1. ¿Con qué frecuencia se reúnen?

Pregunta 10: Le mostraré unas tablas que hacen referencia a cómo se comporta la industria de la joyería. Por favor colocar una $\mathrm{x}$ para medir el nivel de atractividad. En la primera línea cómo se comporta actualmente y en la segunda línea como considera su comportamiento en el futuro.
Gremio de Artesanos

$16 / 03 / 18$

Miraflores

5

Investigar como el propietario de las pequeñas empresas establece redes de contactos para su empresa.

Utilizada en el capítulo 4.2 Tabla de Impacto a clientes

Utilizada en el capítulo 5.3. Matriz de Atractividad de cada una de las cinco fuerzas. Respondiendo a cada uno de los cuadros.

Entrevistador:

Guía del Cuestionario al Gremio de Artesanos

Entrevistado:

Fecha:

Introducción

Se dio la reunión en casa de uno de los Joyeros, ellos se reúnen el tercer viernes de cada mes, no se permitió entrevistas, ni grabaciones, por lo que de manera casual se hicieron dos preguntas a seis de ellos

Objetivo del estudio

Conocer de qué manera los artesanos y joyeros consiguen sus materias primas, como es su relación con los proveedores, clientes. Para poder analizar las fuerzas competitivas de la industria de la joyería en Lima.

Pregunta

Se hicieron algunas preguntas de lo que recordábamos, como se mencionó no les gusta que los graben.

1. ¿Con qué frecuencia se reúnen?

2. ¿Qué tiempo tiene en la industria de la joyería?

3. ¿Cómo es su relación con sus proveedores?

4. ¿Cada que tiempo compra insumos?

5. ¿Cuáles son los meses que más vende?

6. ¿Los clientes piden calidad o precio?

7. Sus productos están certificados?

8. ¿Da información a la competencia? ¿Cómo la obtiene?

9. El cliente le es fiel? Por qué cree? Cómo lo percibe?

10. Le mostraré unas tablas que hacen referencia a cómo se comporta la industria de la joyería. Por favor colocar una x para medir el nivel de atractividad. En la primera línea cómo se comporta actualmente y en la segunda línea como considera su comportamiento en el futuro. 
Desarrollo potencial de productos sustitutos

\begin{tabular}{|c|c|c|c|c|c|}
\hline & 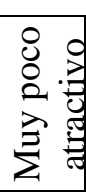 & 8 & $\frac{O}{\Xi}$ & 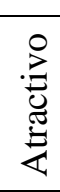 & 总氞 \\
\hline \multicolumn{6}{|l|}{ Tendencia del comprador a sustituir } \\
\hline \multicolumn{6}{|l|}{$\begin{array}{l}\text { Precios relativos de los productos } \\
\text { sustitutos. }\end{array}$} \\
\hline \multicolumn{6}{|l|}{$\begin{array}{l}\text { Coste o facilidad de cambio del } \\
\text { comprador. }\end{array}$} \\
\hline \multicolumn{6}{|l|}{$\begin{array}{l}\text { Nivel percibido de diferenciación de } \\
\text { producto o servicio. }\end{array}$} \\
\hline \multicolumn{6}{|l|}{ Disponibilidad de sustitutos cercanos. } \\
\hline Suficientes proveedores. & & & & & \\
\hline
\end{tabular}

Entrada potencial de nuevos competidores

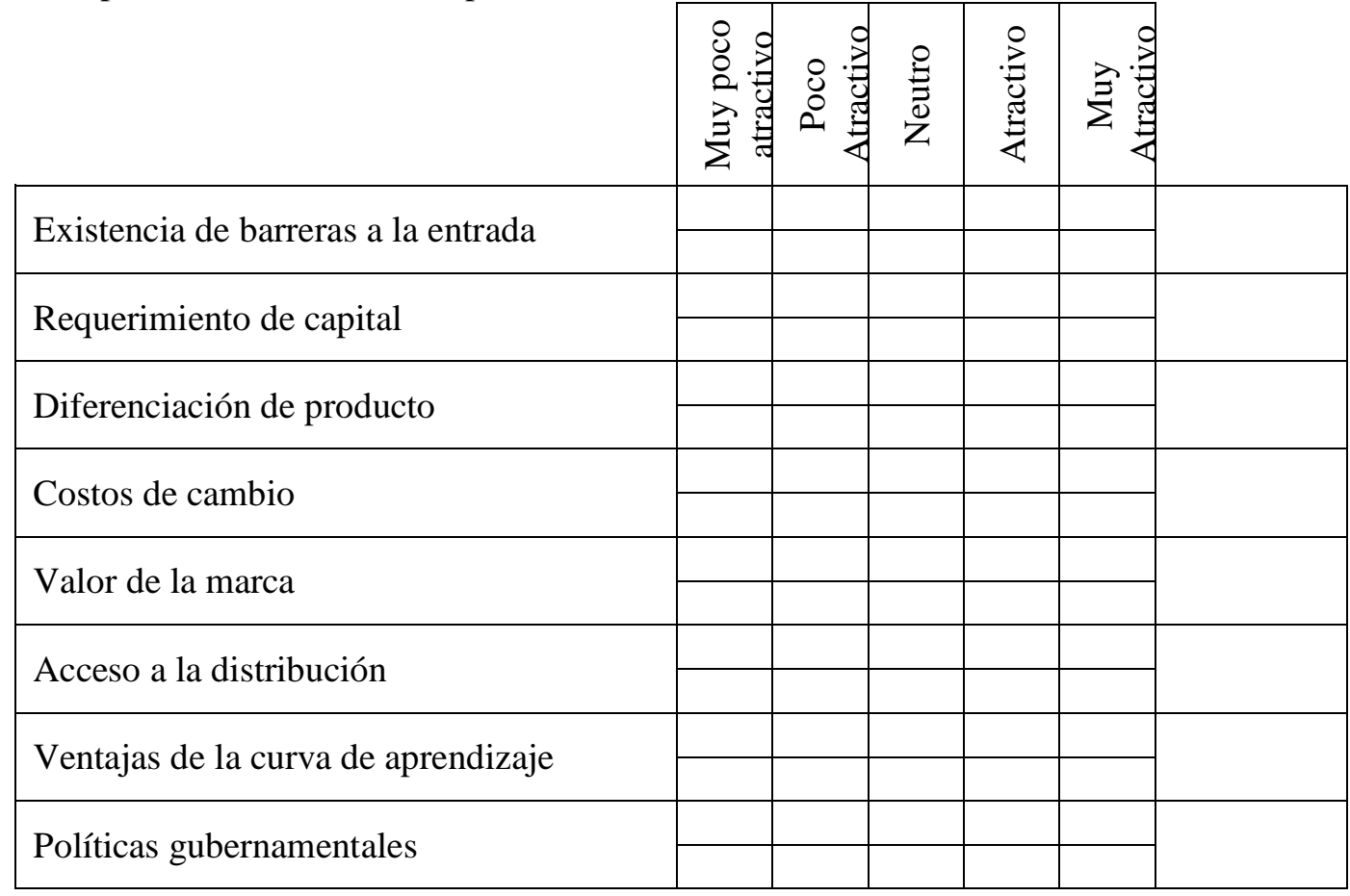


Poder de negociación de los consumidores

\begin{tabular}{|c|c|c|c|c|c|}
\hline & 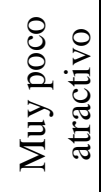 & 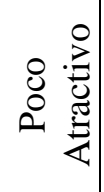 & $\begin{array}{l}\stackrel{0}{\Xi} \\
\stackrel{0}{0} \\
\stackrel{\Xi}{Z}\end{array}$ & 胥 & 总 \\
\hline $\begin{array}{l}\text { El producto comprado no representa } \\
\text { parte importante de sus compras }\end{array}$ & & & & & \\
\hline $\begin{array}{l}\text { Disponibilidad de información para e } \\
\text { comprador. }\end{array}$ & & & & & \\
\hline $\begin{array}{l}\text { La empresa está registrando bajas } \\
\text { utilidades }\end{array}$ & & & & & \\
\hline $\begin{array}{l}\text { Grado de dependencia de los canales } \\
\text { de distribución. }\end{array}$ & & & & & \\
\hline Volumen del comprador. & & & & & \\
\hline $\begin{array}{l}\text { Costes o facilidades del cliente de } \\
\text { cambiar de empresa. }\end{array}$ & & & & & \\
\hline Existencia de productos sustitutos. & & & & & \\
\hline Sensibilidad del comprador al precio & & & & & \\
\hline
\end{tabular}

Poder de negociación de los proveedores

\begin{tabular}{|c|c|c|c|c|c|}
\hline & 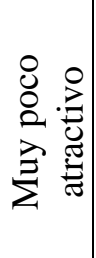 & 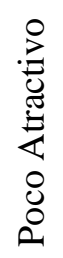 & $\begin{array}{l}\stackrel{0}{\Xi} \\
\stackrel{0}{0} \\
\text { Z }\end{array}$ & 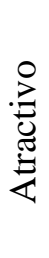 & 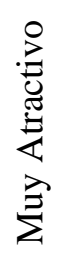 \\
\hline $\begin{array}{l}\text { Sector dominado por pocas empresas } \\
\text { proveedoras }\end{array}$ & & & & & \\
\hline $\begin{array}{l}\text { El producto es diferenciado o tiene } \\
\text { altos costos por cambio }\end{array}$ & & & & & \\
\hline Presencia de productos sustitutivos & & & & & \\
\hline Concentración de los proveedores & & & & & \\
\hline $\begin{array}{l}\text { Coste de los productos del proveedor } \\
\text { en relación con el coste del producto } \\
\text { final. }\end{array}$ & & & & & \\
\hline
\end{tabular}




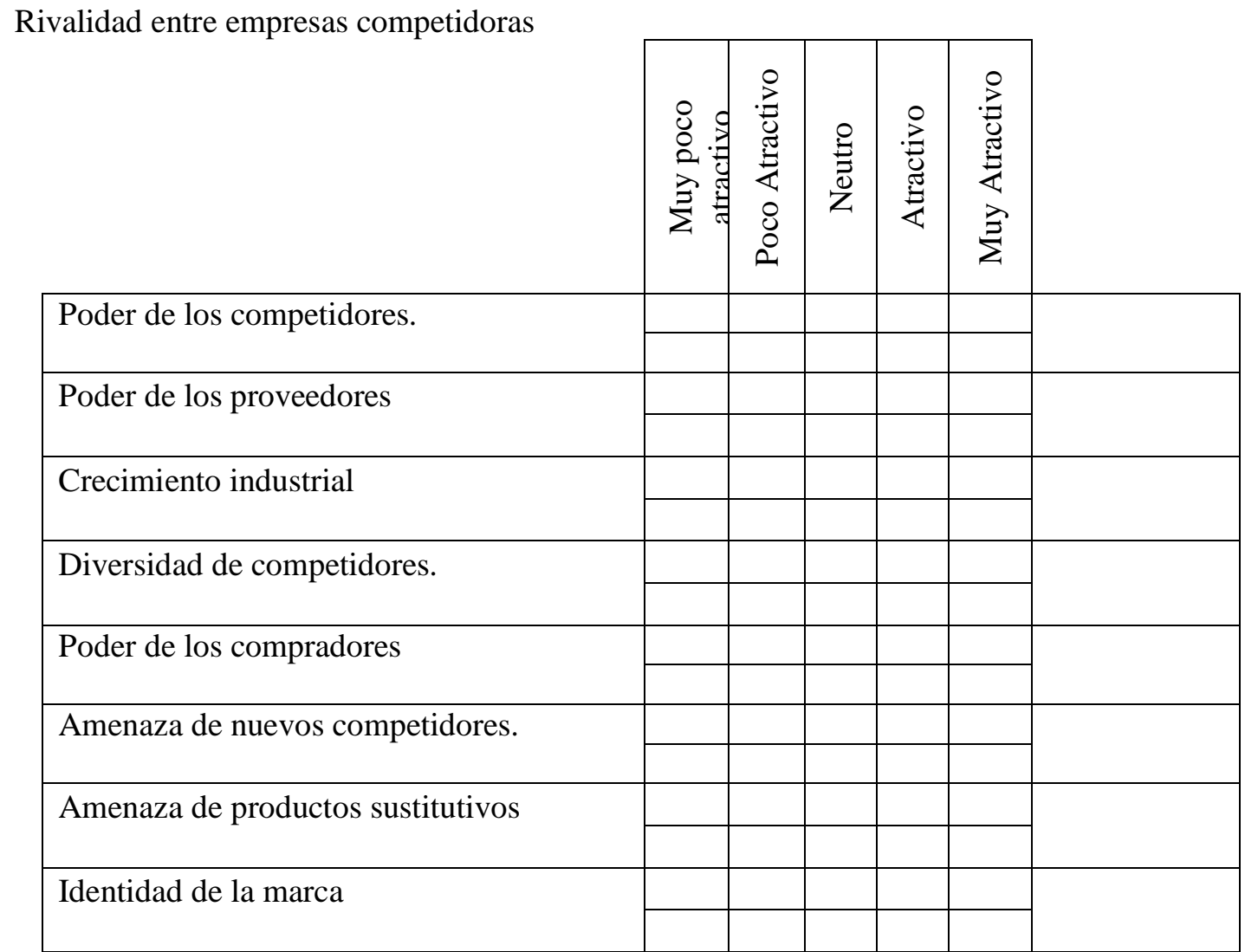




\section{Apéndice B2}

Cuestionario a Clientes de Incas Jewerley SAC

\author{
Grupo: \\ Empresa: \\ Fecha: \\ Vía de envió: \\ Número de personas que llenaron el \\ cuestionario: \\ Objetivo:
}

Pregunta 1. ¿Cuándo visita una joyería busca?; Pregunta 2. ¿Suele comprar joyas de plata? Y Pregunta 5. ¿Qué tipos de accesorios compra con más frecuencia?; Pregunta 8. Razones por las que compra joyas de plata. Pregunta 10. ¿Estaría dispuesto a pagar un poco más por una joya de plata de buena calidad?

Pregunta 3. ¿Con qué frecuencia compra joyas de plata?

Pregunta 5. ¿Qué tipos de accesorios compra con más frecuencia?; Pregunta 8. Razones por las que compra joyas de plata. Pregunta 10. ¿Estaría dispuesto a pagar un poco más por la joya de plata de buena calidad?

Pregunta 9. ¿Le interesa el precio a la hora de comprar?

Pregunta 1. ¿Cuándo visita una joyería busca?
Clientes de Incas Jewelry

Incas Jewelry SAC

$18 / 04 / 18$

Online

49 de 70 enviados

Conocer las preferencias y el comportamiento de compra de nuestros clientes

Utilizado en el capítulo 5.3 Matriz de Atractividad de cada una de las cinco fuerzas: Desarrollo potencial de productos sustitutos

Utilizado en el capítulo 5.3 Matriz de Atractividad de cada una de las cinco fuerzas: Entrada de nuevos competidores.

Utilizado en el capítulo 5.3 Matriz de Atractividad de cada una de las cinco fuerzas: Poder de negociación de los consumidores.

Utilizado en el capítulo 5.3 Matriz de Atractividad de cada una de las cinco fuerzas. Poder de negociación de los proveedores

Utilizado en el capítulo 5.3 Matriz de Atractividad de cada una de las cinco fuerzas 


\section{Guía del Cuestionario de Encuesta a Clientes de Incas Jewelry SAC \\ Encuesta Incas Jewelry SAC \\ Somos alumnos de la Escuela de Posgrado una encuesta a los clientes de Incas Jewelry trabajo académico de Por favor su apoyo respondiendo las sigui}

Sexo

$$
\begin{aligned}
& \square \text { Masculino } \\
& \square \text { Femenino }
\end{aligned}
$$

Edad

De 18 a 25

De 26 a 50

De 50 a más

Nacionalidad

$$
\begin{aligned}
& \square \text { Peruana } \\
& \square \text { Otro }
\end{aligned}
$$

1. Cuando visita una joyería busca:

- Comprar una joya de plata de alta calidad.

- Comprar bisutería con algunas piezas de baile.

- Solo pregunta precios.

2.- ¿Suele comprar joyas de plata?

$$
\begin{array}{ll}
\text { - } & \mathrm{Si} \\
\circ & \mathrm{No}
\end{array}
$$

3. ¿Con qué frecuencia compra joyas de plata?
- Una vez al mes
- Cada dos meses
- Cada tres meses
- Muy rara vez

4. ¿Qué tipo de accesorios compra con más frecuencia?
○ Anillos
- Aretes
○ Pulseras
- Cadenas

5. ¿Qué tipo de accesorios compra con más frecuencia?
○ Diseño
- Material
- Precio
- Tendencia

6. Qué tiene en cuenta al comprar una joya?
○ $\mathrm{Si}$
○ No

7. ¿A la hora de comprar una joya tiene en cuenta su proceso de producción y que no malogren el medio ambiente?
- Muy importante
- Importante
- Indiferente
- Poco Importante
- Nada importante

8. Razones por las que compra joyas de plata
- Uso propio
- Regalos de cumpleaños
- Encargada de las compras de la empresa

9. ¿Le interesa el precio a la hora de comprar?
○ $\mathrm{Si}$
○ No

10. ¿Estaría dispuesto a pagar un poco mas por una joya de plata de buena calidad?

$$
\begin{array}{ll}
\circ & \mathrm{Si} \\
\circ & \mathrm{No}
\end{array}
$$

11. ¿Le gusta las joyas de plata con incrustaciones de piedras naturales?

$$
\begin{array}{ll}
\circ & \mathrm{Si} \\
\circ & \mathrm{No}
\end{array}
$$

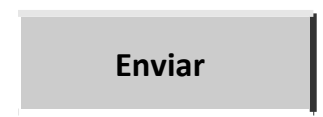


Tabulación de la Guía del Cuestionario de Encuesta a Clientes de Incas Jewelry SAC

\begin{tabular}{|c|c|c|}
\hline Sexo & & $\%$ \\
\hline Masculino & 11 & $23 \%$ \\
\hline Femenino & 37 & $77 \%$ \\
\hline \multicolumn{3}{|l|}{ Edad } \\
\hline De 18 a 25 & 7 & $15 \%$ \\
\hline De 26 a 50 & 26 & $54 \%$ \\
\hline De 50 a mas & 11 & $23 \%$ \\
\hline \multicolumn{3}{|l|}{ Nacionalidad } \\
\hline Peruana & 46 & $96 \%$ \\
\hline Otra & 1 & $2 \%$ \\
\hline \multicolumn{3}{|l|}{ Cuando visita un joyería busca: } \\
\hline Comprar una joya de plata de alta calidad & 29 & $60 \%$ \\
\hline Comprar bisutería con algunas piezas de plata & 13 & $27 \%$ \\
\hline Solo pregunta precios & 5 & $10 \%$ \\
\hline regalo & 1 & $2 \%$ \\
\hline \multicolumn{3}{|l|}{ ¿Suele comprar joyas de plata? } \\
\hline $\mathrm{Si}$ & 41 & $85 \%$ \\
\hline No & 7 & $15 \%$ \\
\hline \multicolumn{3}{|l|}{ ¿Con qué frecuencia compra joyas de plata? } \\
\hline Una vez al mes & 0 & $0 \%$ \\
\hline Cada dos meses & 6 & $13 \%$ \\
\hline Cada tres meses & 17 & $35 \%$ \\
\hline Muy rara vez & 25 & $52 \%$ \\
\hline \multicolumn{3}{|l|}{ ¿Qué tipo de accesorios compra con más frecuencia? } \\
\hline Anillos & 14 & $29 \%$ \\
\hline Aretes & 12 & $25 \%$ \\
\hline Pulseras & 15 & $31 \%$ \\
\hline Cadenas & 8 & $17 \%$ \\
\hline \multicolumn{3}{|l|}{ ¿Qué tiene en cuenta al comprar una joya? } \\
\hline Diseño & 25 & $52 \%$ \\
\hline Material & 15 & $31 \%$ \\
\hline Precio & 7 & $15 \%$ \\
\hline
\end{tabular}

¿A la hora de comprar una joya tiene en cuenta su proceso de producción y que no malogren el medio ambiente?

$\mathrm{Si} \quad 23$

$48 \%$

No

¿Qué tan importante es para usted que los productos sean de calidad?

Muy importante

Importante

Indiferente

Poco Importante

$0 \quad 0 \%$

Nada importante

Razones por las que compra joyas de plata

Uso propio 
Encargada de las compras de la empresa

¿Le interesa el precio a la hora de comprar?

$\mathrm{Si}$

No

¿Estaría dispuesto a pagar un poco más por una joya de plata de buena calidad?

$\mathrm{Si}$

No

¿Le gustan las joyas de plata con incrustaciones de piedras naturales?

$\mathrm{Si}$

No
47

$98 \%$

$12 \%$

$43 \quad 90 \%$

$5 \quad 10 \%$ 